\title{
Democratic Enterprise
}

\section{Ethical business for the 21st century}
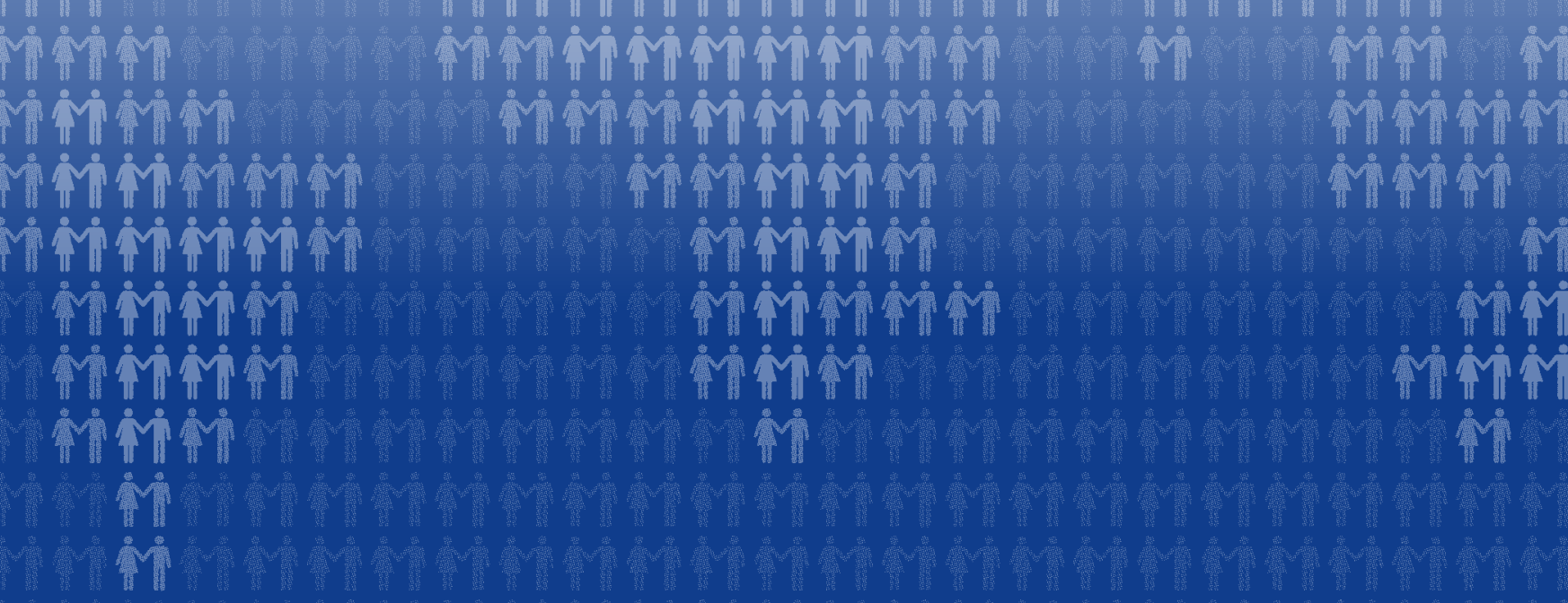


\section{Democratic Enterprise: Ethical business for the 21st century}

A CETS Resource published with the support of the Scottish Government and the Economic and Social Research Council.

\section{(c) (1) (2)}

Democratic Enterprise is licensed under a Creative Commons Attribution-NonCommercialShareAlike 3.o Unported License. Users are free to copy, distribute and transmit this work, as well as adapt it, as long as the following conditions are met:

Attribution

You must attribute the work in the manner specified by the author or licensor (but not in any way that suggests that they endorse you or your use of the work).

Noncommercial

You may not use this work for commercial purposes.

Share Alike

If you alter, transform, or build upon this work, you may distribute the resulting work only under the same or similar license to this one.

Democratic Enterprise is open access, meaning it is free to download online.

Copyright (C) Diarmuid McDonnell, Elizabeth Macknight, and Hugh Donnelly

The publisher has no responsibility for the persistence or accuracy of URLS

for any external or third-party internet websites referred to in this book, and does not guarantee that any content on such websites is, or will remain, accurate or appropriate.

First published 2012 


\section{Contents}

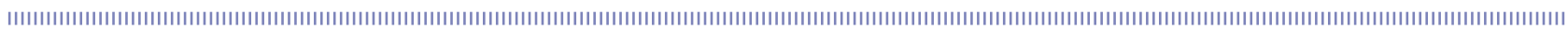

Contents

List of figures $\quad 4$

List of tables $\quad 5$

$\begin{array}{ll}\text { Acknowledgements } & 6\end{array}$

$\begin{array}{ll}\text { Abbreviations } & 7\end{array}$

Guide to the resource $\quad 9$

$\begin{array}{lr}\text { Preface } & 10\end{array}$

$\begin{array}{ll}\text { Introduction } & 11\end{array}$

1. The ethical alternative: co-operative values and principles 13

2. More than just profit: the co-operative business model 29

3. ...of the people, by the people, for the people: co-operative governance 47

4. Co-operative societies in society: classifications and incorporation 63

5. Democracy in the workplace I: worker co-operatives 77

6. Democracy in the workplace II: employee ownership 99

7. An acceptable face of capitalism?: arguments for and against employee ownership 119

8. The rise and fall of industrial democracy: employee ownership and the business cycle 135

9. Democratic enterprise: the invisible giant? 149

$\begin{array}{ll}\text { Epilogue } & 166\end{array}$

$\begin{array}{ll}\text { Glossary } & 167\end{array}$

$\begin{array}{ll}\text { Key web resources } & 171\end{array}$

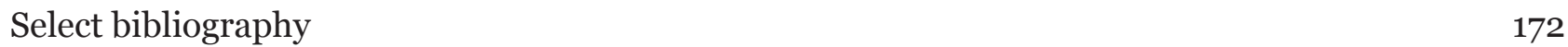

$\begin{array}{lr}\text { Index } & 180\end{array}$ 


\section{List of figures}

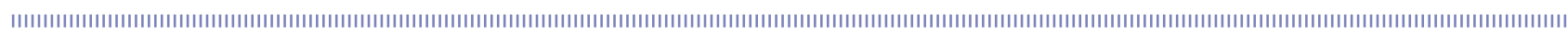

$\begin{array}{lll}\text { Figure } 1 & \text { The Co-operative Advantage paradigm } & 23\end{array}$

Figure 2 Example of surplus allocation (after tax) in a co-operative 36

$\begin{array}{lll}\text { Figure } 3 \text { The co-operative business model } & 37\end{array}$

$\begin{array}{lll}\text { Figure } 4 & \text { Overview of co-operative governance } & 51\end{array}$

$\begin{array}{lll}\text { Figure } 5 & \text { Typical governance structure of a worker co-operative } & 83\end{array}$

Figure 6 Organisational structure of an individual Mondragón co-operative 90

$\begin{array}{lll}\text { Figure } 7 & \text { Mondragón Corporation organisational structure } & 92\end{array}$

$\begin{array}{lll}\text { Figure } 8 & \text { Global membership of co-operatives } & 152\end{array}$

$\begin{array}{lll}\text { Figure } 9 & \text { Global30o project } & 153\end{array}$

$\begin{array}{lll}\text { Figure } 10 & \text { Number of co-ops by country (UK) } & 154\end{array}$

Figure 11 Percentage growth of the UK movement 154

$\begin{array}{lll}\text { Figure } 12 & \text { Trends in UK income inequality } & 158\end{array}$

$\begin{array}{lll}\text { Figure } 13 \text { Trust in institutions 2008-2011 } & 159\end{array}$

Figure 14 Public perception comparison of co-ops and PLCs 160 


\section{List of tables}

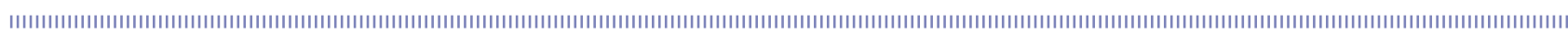

$\begin{array}{lll}\text { Table } 1 & \text { Values and priorities of well known investor-owned businesses } & 16\end{array}$

Table 2 Sample patronage refund calculation 36

Table $3 \quad$ Comparison of enterprise models 42

Table $4 \quad$ Responsibilities of governance participants $\quad 54$

Table 5 Corporate governance theories and their impact on the board 56

Table $6 \quad$ Elements of managerial competence in consumer co-operatives $\quad 57$

Table $7 \quad$ Factors that influence the success of co-operative management $\quad 58$

Table $8 \quad$ Area-based classification of co-operatives $\quad 65$

Table 9 Membership-based classification of co-operatives 66

Table 10 Group-served classification of co-operatives $\quad 66$

$\begin{array}{lll}\text { Table } 11 & \text { Comparison of business structures } & 73\end{array}$

Table 12 Relationship between labour and capital in conventional $\begin{array}{ll}\text { and co-operative enterprises } & 80\end{array}$

$\begin{array}{lll}\text { Table } 13 & \text { Specification of worker co-operative members } & 81\end{array}$

Table 14 Management theories for worker co-operatives $\quad 85$

Table 15 Mondragón Principles of Co-operation 93

$\begin{array}{lll}\text { Table } 16 & \text { Sample ESOP vesting process } & 111\end{array}$

$\begin{array}{lll}\text { Table } 17 & \text { The three forms of employee ownership } & 114\end{array}$

Table 18 Summary of co-operative sector in UK 153

Table 19 US ESOPs and share plans $\quad 156$ 


\section{Acknowledgements}

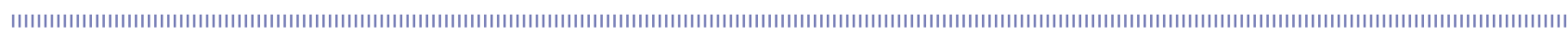

The authors thank the Scottish Government and the Economic and Social Research Council for generous sponsorship of the Knowledge Transfer Partnership (KTP) grant which facilitated the research for this publication. We are also grateful to Scotmid, Co-operative Development Scotland, and The Co-operative Group for their important financial contributions. The guidance and enthusiasm of Robin Brown, Manager of the KTP North of Scotland Centre, was crucial at every stage of establishing the Partnership. We deeply appreciate Robin's ongoing support and Sarah Stott's cheerful handling of the KTP administration. Gerry Black, Senior KTP Adviser for Scotland, has been critically engaged in helping us to achieve optimal outcomes for the Partnership. Gerry's perspective on our work has been extremely valuable. Thanks to Martin Meteyard for help and efficiency in the task of proof-reading the text. Michelle Lile at The Graphics Company brought creative and professional skills to the design of the book.

For permission to reproduce previously published material, we thank the following authors and publishers: Edgar Parnell, Cooperative Extension Publishing, Loren Rodgers, Giles Simon, Andrew Pendleton, and the International Co-operative Alliance. 


\section{Abbreviations}

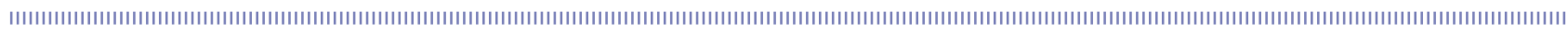

ABCUL Association of British Credit Unions Limited

AGM Annual General Meeting

CDA Co-operative Development Agency

CDS Co-operative Development Scotland

CECOP European Confederation of Workers' Co-operatives, Social Co-operatives and Social and Participative Enterprises

CFS Co-operative Financial Services

CIC Community Interest Company

CLG Company Limited by Guarantee

CLP Caja Laboral Popular

CLS Company Limited by Shares

COGS Cost of Goods Sold

CPF Co-operative Productive Federation

CSO Co-operative Support Organisation

CSR Corporate Social Responsibility

DE Democratic Enterprise

EBO Excellence by Owners

EBT Employee Benefit Trust

EO Employee Ownership

EOA Employee Ownership Association

ESOP Employee Stock Ownership Plan

FED Foundation for Enterprise Development

FSA Financial Services Authority

HMRC Her Majesty's Revenue and Customs

HRM Human Resource Management

ICA International Co-operative Alliance

ICOF Industrial Common Ownership Finance

ICOM Industrial Common Ownership Movement

IOC/IOB Investor-owned Company/Business

IPS Industrial and Provident Society 
MC Mondragón Corporation

NCBA National Cooperative Business Association

NCEO National Center for Employee Ownership

OEOC Ohio Employee Ownership Center

SAIC Science Applications International Corporation

SME $\quad$ Small and Medium Enterprise

UA United Airlines

USP Unique Selling Point 


\section{Guide to the resource}

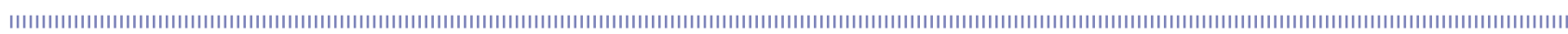

This resource provides a comprehensive introduction to the subject of co-operatives and employee ownership. It is designed for use in universities with due regard for best practice in flexible delivery, blended learning, and curricula innovation.

- Chapters 1, 2, 3, and 4 cover the essential elements of a co-operative enterprise; chapters 5 and 6 do the same for employee ownership.

- Chapters 7 and 8 provide a more in-depth analysis of employee-owned businesses, addressing the arguments for and against employee ownership, and the lifecycle of these enterprises.

- Chapter 9 examines the international context in which democratic models of enterprise operate.

To obtain maximum value from the learning experience associated with this resource, instructors and students are encouraged to use the specifically developed virtual learning environment (VLE) at http://cets.coop/moodle. A range of learning and teaching materials are provided, including:

\section{For instructors:}

- Seminar exercises

- Instructor's manual containing detailed notes on learning outcomes, key arguments, sample essay questions and useful resources

- Sample lecture slides

\section{For students:}

- Additional case studies

- Journal articles

- Key reports

- Links to relevant websites

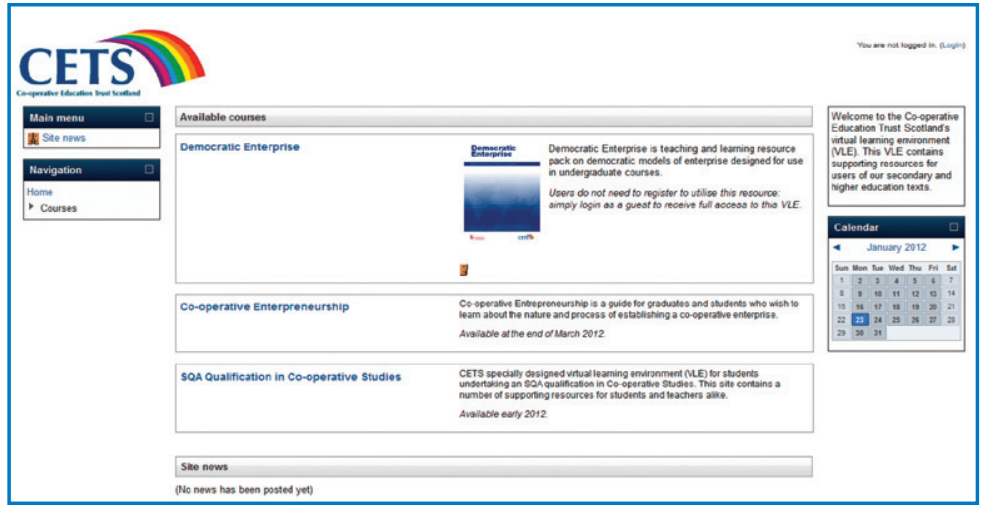


'The Business School ... with its glass atrium and brochure that implies a ticket to the plush business lounge ... aims itself at the global managerial class. It does not, by and large, sell its wares to voluntary organisations, co-operatives or trade unions, and its relationship with the public sector is uneasy.'

Harsh words from Martin Parker (Warwick Business School) in the aftermath of the 2008 financial meltdown, but ones which struck a chord with many, especially those who had not attended business school and had no 'golden parachutes' to soften their economic descent.

As someone who had worked in co-operative and employee ownership development for over two decades, I found Parker's statement had a certain resonance. It had become increasingly obvious to me that it was the norm for graduates, even after many years of education, perhaps culminating in an MBA, to have only minimal knowledge and understanding in this area of business studies. The prevailing neo-liberal free market orthodoxy had strangled any consideration of alternatives, such as those offered by the co-operative sector. Hugely discouraging from an educational point of view, but then if you don't teach the subject you can't expect students to learn! There is also the irony, or should that be hypocrisy, that the entire free market orthodoxy is premised on the existence of rational economic man making free choices based on perfect information. Without information on co-operative business structures, how do you make that rational choice?

We hope that this publication will be a step towards ensuring that more of our citizens are offered more choices when it comes to organising enterprises and ordering society. It might not generate one hundred per cent take up of co-operative options but given the level of dissatisfaction and disaffection with the current system, it might just be the alternative that many seek. Maybe it is time to re-invent the co-operative.

Hugh Donnelly

Managing Director

Co-operative Education Trust Scotland 


\section{Introduction}

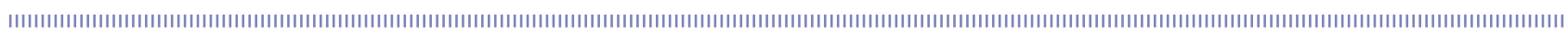

On 9 August 2007, French investment bank BNP Paribas announced that it would not allow customers to withdraw capital from two of the company's funds, owing to a 'complete evaporation of liquidity' in the financial markets. ${ }^{.}$So began the financial crisis known as the credit crunch, which continues to impact upon the global economy in 2012. The effects of BNP Paribas's announcement were felt around the world: central banks moved rapidly to shore up insolvent governments, governments frantically pumped taxpayers' money into insolvent financial institutions, while banks and other financial institutions desperately tried to meet the stringent criteria of rating agencies in order to retain the low rate at which they could borrow money as a means of staving off insolvency.

The 15 September 2008 became a defining date in the development of the global financial crisis. Lehman Brothers, one of the largest investment banks in the world with over $\$ 600$ billion in assets, filed for chapter 11 bankruptcy in the US courts. ${ }^{2}$ Established in 1844 as a dry-goods store, the company had prospered for 164 years before succumbing to the ills arising from excessive risk-taking in the financial sector. A year earlier, Northern Rock, a former mutual organisation that converted to investor ownership, requested and was granted emergency funds from the Bank of England, a move that precipitated a run on the bank's deposits by worried customers. Whilst the financial crisis claimed companies on an almost weekly basis, another sector of the economy went about its business in a sustainable manner, unfettered by reckless lending and unethical behaviour. This sector is driven not by profit-maximising investor-owned businesses, but rather by models of enterprise founded on a different set of principles. In 2008, a UK co-operative business celebrated its $164^{\text {th }}$ anniversary by posting record revenue and profit figures, all achieved against a backdrop of economic uncertainty. In Spain, an organisation representing over eighty thousand workers continued to expand and develop an experiment in industrial democracy which began more than fifty years ago. In the US, collectively-owned utility businesses continued to provide energy services for over forty million people in rural areas. And thousands of businesses across the globe decided to share the wealth they generated with their employees during a time when financial uncertainty and income disparity reached unprecedented levels.

Organisations within the co-operative sector operate under the radar of mainstream economics and education, yet they have survived and even performed better than investor-owned enterprises during the most turbulent social and economic periods of the past two hundred years. This book sets out to dispel confusion and misinformation about these businesses. By improving knowledge and understanding of co-operatives we can begin a process of spreading wealth more equitably throughout society.

1. 'Timeline: Credit crunch to downturn' BBC News 7 August 2009. http://news.bbc.co.uk/1/hi/7521250.stm, accessed 3 September 2011.

2. S. Mamudi, 'Lehman folds with record $\$ 613$ billion debt' MarketWatch 15 September 2008. http://www.marketwatch.com/story/ lehman-folds-with-record-613-billion-debt?siteid=rss, accessed 3 September 2011. 


\section{The ethical alternative: co-operative values and principles}

'Founded on the principles of private initiative, entrepreneurship and selfemployment, underpinned by the values of democracy, equality and solidarity, the co-operative movement can help pave the way to a more just and inclusive economic order.'

Kofi Annan

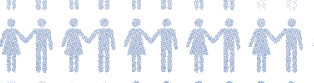

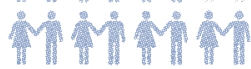

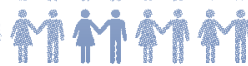

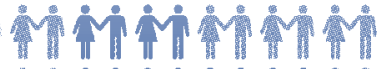

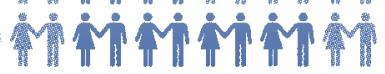

poivi ivi

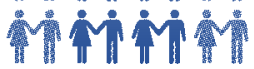

Mivi

in

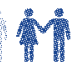

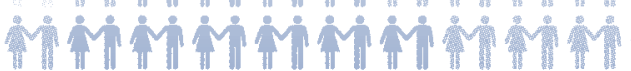

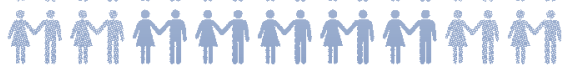

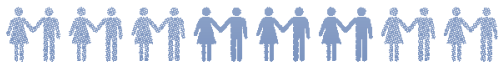

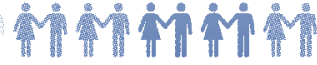

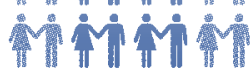

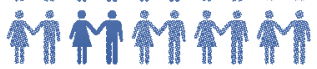

Mimi

in

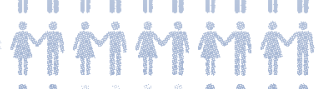

到

Min

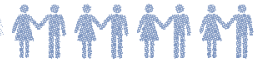

Mำำ Mำำ

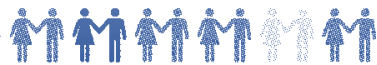

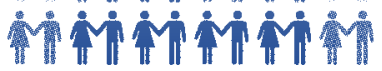
栾 M 


\section{The ethical alternative: co-operative values and principles}

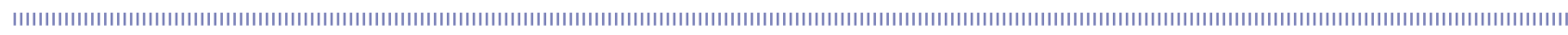

\section{Learning objectives}

This chapter introduces the co-operative model of enterprise by explaining the internationally recognised values and principles that underpin it. These values and principles are integral to the identity of co-operatives and provide them with an inherent advantage over other forms of business organisation. By the end of this chapter you will be able to:

- evaluate the relevance of the co-operative values and principles to business and society in the twenty-first century;

- analyse the effects of the principles on the operation of co-operative enterprises;

- discuss the concept of a co-operative advantage and ways in which it can be utilised.

\section{The key arguments that will be developed in this chapter are:}

The co-operative values and principles are as relevant to business and society in the twentyfirst century as they were when they were first devised over 150 years ago.

The values and principles can be used to distinguish co-operative businesses from other models of enterprise.

The co-operative advantage provides the potential for co-operatives to sustain a competitive edge over traditional forms of enterprise.

\section{Introduction}

A co-operative is a business. It resembles any other business in the sense that it trades in the market and uses the factors of production (land, labour, and capital) in order to produce goods or services. What makes the co-operative business model unique? To the casual observer, there may seem to be little difference between a co-operative food retailer and an investor-owned food retailer. This is because both retailers will have very similar operations, processes, stock, supply chains, and pricing. Co-operatives differentiate themselves primarily through their values and principles.

To celebrate its centennial year in 1995, the International Co-operative Alliance (ICA) adopted the following definition of a co-operative in its Statement on the Co-operative Identity: 
A co-operative is an autonomous association of persons united voluntarily to meet their common economic, social, and cultural needs and aspirations through a jointly-owned and democratically-controlled enterprise. ${ }^{1}$

\section{Values}

The Oxford English Dictionary defines values as 'principles or standards of behaviour; one's judgement of what is important in life'. Co-operatives are based on the following values:

- self-help

- self-responsibility

- democracy

- equality

- equity

- solidarity

In the tradition of the earliest co-operative founders, co-operative members today believe in the practice of honesty, openness, social responsibility and caring for others. ${ }^{2}$

In a general way this is comparable to the situation in the corporate world where many companies aspire to abide by a set of values that relate to the company's priorities. A company will refer to its set of values in mission statements, marketing, and policies for corporate social responsibility (CSR) which may be found on the company website.

Table 1-Values and priorities of well known investor-owned businesses

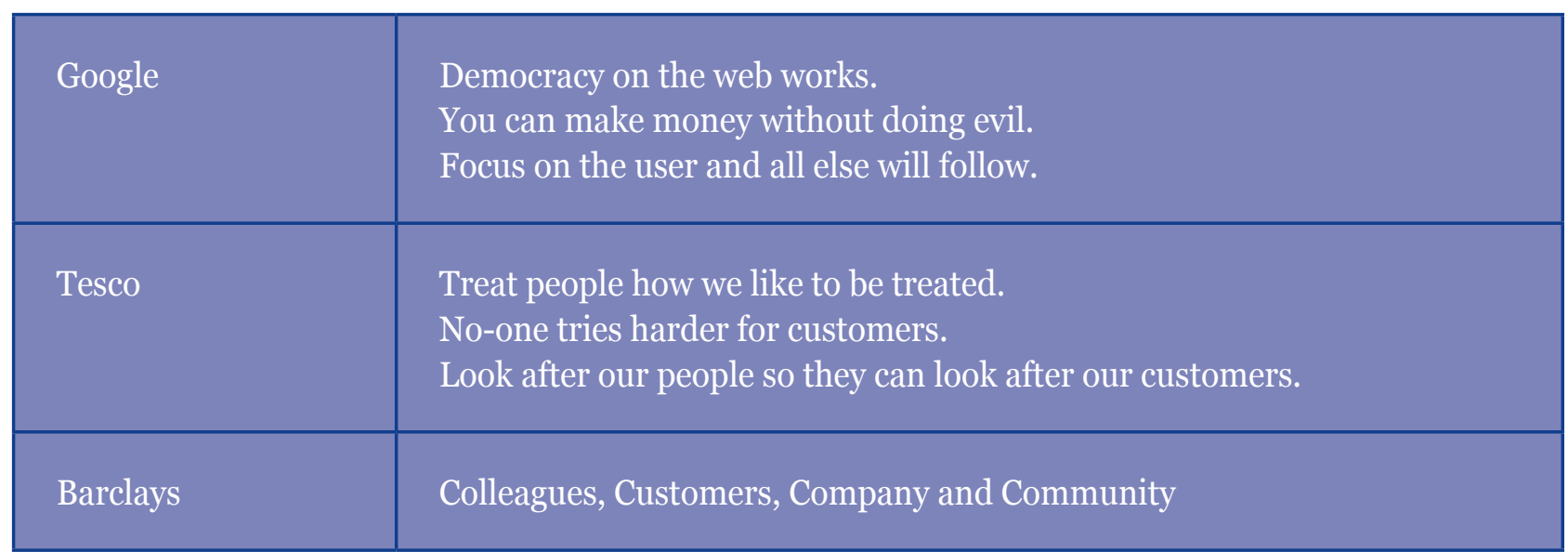

Studying the values and priorities of these three corporate giants, we can see that there are some similarities with the values of co-operative enterprises. There is a commitment to community, the drive to place users or customers at the core of the business, and the goal to treat colleagues or employees in an equitable manner. Co-operatives, therefore, are not distinguished by the fact that they operate according to a set of values, but rather by the manner in which they put their values into practice. ${ }^{3}$ 
The co-operative principles are what distinguish co-operative businesses from other forms of enterprise. Principles are defined in the Oxford English Dictionary as 'a fundamental truth or proposition that serves as the foundation for a system of belief or behaviour'. The co-operative principles act as an essential guide for how a co-operative should operate and organise itself with respect to its values.

\section{Case study 1.1 - Origins of the principles ${ }^{4}$}

The co-operative principles that exist today originated with the Rochdale Society of Equitable Pioneers founded in 1844. Since then the principles have been revised in 1937, 1966, and most recently in 1995 when the ICA also produced the Statement on the Co-operative Identity.

\section{The Rochdale Principles (circa 1860): ${ }^{5}$}

1. The members should provide the capital.

2. There should be a limited rate of return on this capital.

3. Provide high quality produce to members, including full weight and measure.

4. Charge market prices and no credit should be given or asked.

5. Pro rata distribution of profits amongst members.

6. Democratic control (one person, one vote).

7. Allocation of a certain percentage of profits to education.

8. Sharing of financial information with members.

It is interesting to note some of the business innovations and standards that the Rochdale Pioneers implemented in conjunction with their contribution to co-operative principles.

For instance, notice how they operated a business strictly on cash (a great example of an efficient working capital model - see chapter 2); their commitment to providing quality produce at fair prices (non profit maximising); and the introduction of a system whereby information relating to the financial performance of the co-operative was made available to the members. Transparency with regard to finance is increasingly valued in many sectors and organisations today. ${ }^{6}$

\section{First principle: voluntary and open membership}

Co-operatives are voluntary organisations. They are open to all persons who wish to use the co-operative's services and who are willing to accept the responsibilities of becoming a member. Of critical importance, membership is non-discriminatory in respect to age, gender, social background, race and ethnicity, political and religious beliefs. In addition, membership of the co-operative should not be influenced or restricted by external entities such as the government or state laws.

This first principle of voluntary and open membership also means that if a member wishes to leave a co-operative, then that decision can be made without fear of prejudice or discrimination. 


\section{Second principle: democratic member control}

Co-operatives are democratic organisations controlled by their members. This means that people who join should actively participate in setting the co-operative's policies and making decisions. Individuals serving as elected representatives are accountable to the membership. In 'primary co-operatives' members have equal voting rights; in other words, 'one member, one vote'. 'Secondary co-operatives', which are federations made up of several co-operatives, are also organised in a democratic manner.

This second principle is central to the unique enterprise model of co-operatives. In addition to being jointly-owned by members, co-operatives are member-controlled on a democratic basis. Governance in a co-operative is based on 'one member, one vote', whereas in investor-owned firms it is based on the amount of shares held in the business.?

\section{Third principle: member economic participation}

Members contribute equitably to the capital of their co-operative over which they exert democratic control. Part of that capital is usually the common property of the co-operative. Capital in a co-operative is an instrument. By that we mean that capital is necessary for the successful operation of the business but it is not the driving force behind the enterprise. Capital is a means to an end - to provide benefits to members - rather than an end in itself.

This third principle is important in protecting member control of the co-operative, for it prevents those who subscribe capital to the business from subverting the operations of the co-operative to serve their own financial interests. Most co-operatives, however, do provide a limited return on the capital subscribed by members. For example, the Mondragón worker co-operatives stipulate that each member must contribute between $€ 8,000$ and $€ 14,000$ in capital when they join. Each year, a fixed return on this capital is paid (7.5 per cent in some co-operatives) and, in addition, each member receives his or her share of the profits. ${ }^{8}$

The principle of member economic participation also helps to determine how profit (known as surplus) in a co-operative is treated. Since the purpose of a co-operative is to provide benefits to its members, most co-operative enterprises choose to reinvest most of the surplus they generate back into the business, in the form of reserves. Usually, the remainder of the surplus is distributed on a pro-rata basis to members - that is, based on the amount of trade a member conducts with the co-operative (or it could be based on labour contribution in the case of a worker co-operative). It would be reasonable to assume that distributing all of the profit to its members would be the best way for a co-operative to achieve its purpose; however, given the difficulties that co-operatives experience when trying to raise capital, it is important to reinvest much of the surplus back into the business to facilitate future growth and to ensure sustainability.

\section{Co-operative fact}

The Rochdale Society of Equitable Pioneers was not the first co-operative to distribute profits amongst its members on a patronage basis - that is, based on trade. The Lennoxtown Friendly Victualling Society in Scotland, which was formed in 1812, introduced this practice some time before 1826 when it was first recorded. The society no longer exists in its original form due to subsequent mergers, but there is still a Co-operative Food store in Lennoxtown and it will be celebrating its 200th anniversary in $2012 .{ }^{9}$ 


\section{Fourth principle: autonomy and independence}

Co-operatives are autonomous, self-help organisations controlled by their members. If they enter in to agreements with other organisations, including governments, or raise capital from external sources, they do so on terms that ensure democratic control by their members and maintain their co-operative autonomy.

This fourth principle is designed to protect the member-based ownership structure of a cooperative. From a financial perspective, there is nothing, in theory, that prevents co-operatives from raising capital from external sources. Equity capital, however, is usually not available to co-operatives due to the fact that the entity providing the equity would require an ownership stake in the business, thereby eroding the member-based ownership structure.

Governments, primarily in developing economies, have championed and supported co-operatives as a means of achieving public objectives such as reducing poverty and hunger. In some cases, this leads to the government in question seeking to control the affairs of the co-operative. This occurred in Poland in the 1970s when the government sought to use housing co-operatives as means of driving economic expansion; this resulted in the co-operatives working for the benefit of the government instead of their members. Similar situations arose in Africa with agricultural co-operatives and in India with dairy co-operatives. ${ }^{10}$

\section{Fifth principle: education, training, and information}

Co-operatives provide education and training for their members, elected representatives, managers, and employees so they can contribute effectively to the development of their co-operatives. They inform the general public - particularly young people and community leaders - about the nature and benefits of co-operation.

It is sometimes suggested that this fifth principle is not such a distinguishing feature of co-operatives since most organisations provide training for their staff and inform the public of their operations. Nevertheless, co-operatives can demonstrate a remarkably long track record of commitment to education as a social good, prior to the introduction of universal education in developed countries. There are various questions that need to be considered regarding the importance of education in a co-operative:

- What is meant by co-operative education? Does it mean providing information and raising awareness about co-operatives? Or, alternatively, does it mean providing education in a co-operative manner?

- Should co-operative education relate to the practice of co-operation, the ideology of co-operation, or both of these topics?

Most co-operators agree that education of the three main stakeholders in a co-operative (the members, the public, and employees) is crucial to ensure the sustainability and longterm success of the co-operative, as well as it being essential for the practice of democracy in a co-operative (and possibly in society as well). ${ }^{11}$

\section{Sixth principle: co-operation among co-operatives}

Co-operatives serve their members most effectively, and strengthen the co-operative movement, by working together through local, regional, national, and international structures. This sixth principle can be interpreted in different ways. For instance, it may be seen as a call for cooperatives to form federations or 'secondary co-operatives' in which the membership consists wholly of other co-operatives. This corporate structure has been used around the world to create 
some large and highly successful business groups, such as Crédit Agricole, and also major trade and representative bodies such as the US Federation of Worker Co-operatives, Mondragón Corporation (MC), Amul, Co-operatives UK, and the ICA.

The sixth principle can also be applied to individual co-operative enterprises creating co-operative links in the same industry or sector. For example, in the late 1980 os GreenCity Wholefoods, a worker co-operative based in Glasgow, was finding it difficult to supply the northern regions and islands of Scotland in a profitable manner. Around the same time, a wholefoods co-operative in Inverness had ceased trading, which left a gap in the market. GreenCity swiftly came to the conclusion that working in partnership with a local distributor would provide a better service to customers and so helped five unemployed locals to form a new worker co-operative, Highland Wholefoods. A bank loan to help them get started was guaranteed not just by GreenCity but by other wholefood co-operatives in the UK. GreenCity and Highland Wholefoods continued to co-operate in subsequent years: for instance, Highland Wholefoods were able to send new members to GreenCity for training.

The principle does not mean that a co-operative enterprise must source all of its services and/or raw materials from other co-operatives. In many cases this would be impractical, both logistically and financially. Examples have shown, however, that co-operation with other co-operatives can contribute to a rapid scaling up of operations and to the development of entire co-operative ecosystems within communities. ${ }^{12}$

With regards to non-core business activities it is imperative that co-operatives work closely with one and other in order to further the aims of the movement. By educating members and the public, lobbying policy makers and legislators, and supporting local, national, and international causes, co-operatives can achieve so much more together than they can alone. There is tremendous potential for positive action in this sixth principle.

\section{Seventh principle: concern for community}

Co-operatives work for the sustainable development of their communities through policies approved by their members. Early co-operatives were set up with the purpose of creating selfsustaining communities based on commonly-owned land and the principles of co-operation. Modern co-operatives retain this aim of sustainability. Financial co-operatives, such as credit unions, help alleviate poverty by providing financial services to some of the most deprived communities and regularly support local initiatives with grants. Similarly, housing co-operatives provide decent, affordable housing to local communities across the world. The Co-operative Group is at the forefront of beneficial community initiatives through their fund for community development, the Green Schools Revolution, and the Co-operative Enterprise hub. ${ }^{13}$

It is worth highlighting the importance investor-owned companies are placing on CSR to aid understanding of this seventh principle. Large organisations now regularly produce CSR reports detailing their community activities in a given year. However, these organisations achieve community benefits outside of their main business operations not because of them. Most cooperative enterprises place sustainable community development at the core of what they do, rather than treating it as a separate activity. A good example of this is the support given by The Co-operative Group to remote community co-operatives in the Scottish Highlands \& Islands by allowing them access to its supply chain. ${ }^{14}$ 


\section{EXERCISE - The co-operative model}

In the video found at the link below, Hanover Consumer Cooperative Society, located in Vermont and trading since 1936, discusses how the principles distinguish co-operatives from other types of businesses. Watch the video and consider the following questions:

1. Can a business be a co-operative without adhering to all or some of the ICA principles? What do you think the narrator meant by the term 'true co-operative'?

2. The video alludes to the privileges and responsibilities of being an owner (member) of a co-operative. What are these privileges and responsibilities and do they differ from being an owner of a conventional (investor-owned) business?

Video: http://vimeo.com/8572475

\section{Principles in practice}

The ICA principles do not apply to all co-operatives in every business situation, but they do serve as a crucial guide. For example, housing co-operatives cannot feasibly have an open membership policy since they have a limited amount of housing stock; and a worker co-operative can only provide a limited number of jobs. Credit unions restrict membership based on financial criteria. ${ }^{15}$ It is generally agreed that the principles which best define and distinguish co-operative businesses from other forms of enterprise relate to three questions:

- Who benefits from the business?

- Who controls the business?

- What is the role of capital in the business?

Keep these questions in mind as you read the case study of principles in practice below.

\section{Case study 1.2 - The Co-operative Bank}

Member-owned, customer-led, and ethically-guided

Created in 1872, The Co-operative Bank is a financial services provider that is part of Co-operative Banking Group, which in turn is part of The Co-operative Group, Britain's largest consumer cooperative. In 2010, the Bank was the recipient of the Financial Times Sustainable Bank of the Year award. The judging panel noted the Bank's achievements in 'integrating social, environmental and corporate governance considerations into their operations'. This award was recognition for the sustainable and ethical approach to banking that the business has aspired to since it was founded. A leading factor in the attainment of this award is the customer-driven ethical policy the Bank developed in 1992. This ethical policy has evolved into the Bank's competitive advantage over Britain's other high street banks. 


\section{Background}

A cursory glance at The Co-operative Bank reveals a set-up that is similar in terms of its business model to others in the financial services sector. The Bank offers savings, loans, mortgages, credit cards, investment and other common financial products to individuals and businesses alike. It has almost 350 branches, over six million customers, and a record of innovation in the banking sector having launched the first fully online bank in the UK, 'smile', in 1999. The Bank reported an operating result of $£ 108.6 \mathrm{~m}$ in the first half of 2011, thirty-seven per cent higher than the equivalent period in 2010, with assets of $£ 46.4 \mathrm{bn}$.

The Bank's purpose is 'to be a pioneering business delivering sustainable financial services for members and customers'. The distinguishing factor between The Co-operative Bank and other major financial service providers such as Barclays and HSBC is not the pursuit of profit but the way in which that profit is generated, otherwise known as 'the co-operative difference' . And at the heart of the co-operative difference is the Bank's ethical policy, the first amongst Britain's high street banks and still unique in 2011.

\section{What is the ethical policy?}

In essence, the ethical policy stipulates the types of partners with whom the Bank will or will not do business. ${ }^{16}$ The ethical policy serves as a guarantee by the bank that it will use its customers' money in a way that aligns with its stated values. This has real ramifications for the bank; it is not simply a vague statement on corporate social responsibility (CSR). Since 1992, the Bank has withheld over $£ 1$ bn in funding to businesses that contravene the ethical policy. According to the Bank, 'it's a price worth paying to run a business that our customers can feel proud of.'

\section{How is the ethical policy implemented?}

The Bank operates a rigorous compliance process for ensuring each new business customer conforms to the ethical policy. Firstly, the potential business customer must fill out an ethical questionnaire as part of their application, which is then assessed against the ethical policy. If there are concerns or queries, the application is passed onto the Ethical Policy Unit where it is assessed against the policy statements and the database of over 1,700 case studies kept by the Bank. The effect of a customer's business on the Bank's bottom line plays no role in the final decision on whether or not to accept their application.

\section{The future}

David Anderson, former Chief Executive, notes: 'One third of our profits come from customers who have joined just because of the ethical policy.' The Co-operative Bank continues to deliver sustainable and profitable performance guided by its unique customer-led ethical policy. This shows that a co-operative values-based business model can be used to develop a competitive advantage over conventional businesses by leveraging the ethical commitment and values of members and customers. In Anderson's words: 'We believe that by doing this we can invest for the long-term benefit of customers and, at the same time, use our influence as an investor to improve our environment and society.'

Source: http://www.youtube.com/watch?v=YrXWTXuShlQ 


\section{The co-operative advantage}

In business, much thought and effort is given by management towards the creation of a 'competitive advantage', something that distinguishes a company from its competitors. A competitive advantage can be created by providing added value to customers, something more than your competitors can offer, coupled with the harmonisation of each process or function in a company to achieve its objectives. ${ }^{17}$ Creating a competitive advantage, therefore, is about differentiating your business from others in your industry. This task becomes slightly more difficult for co-operatives if they choose to define themselves in relation to their competitors based only on product, service, information systems, and so on. The key step for co-operatives is to leverage their 'co-operative advantage' to create a unique selling point (USP) that will not only provide increased benefits for members but also create a stronger bottom line.

\section{What is a co-operative advantage?}

A co-operative advantage is a co-operative's equivalent of a competitive advantage. Its foundation is the unique ownership and governance structure inherent in all co-operatives - the fact that the business is member-owned and member-controlled. The following diagram illustrates how a cooperative advantage is derived.

\section{Figure 1-The Co-operative Advantage paradigm}

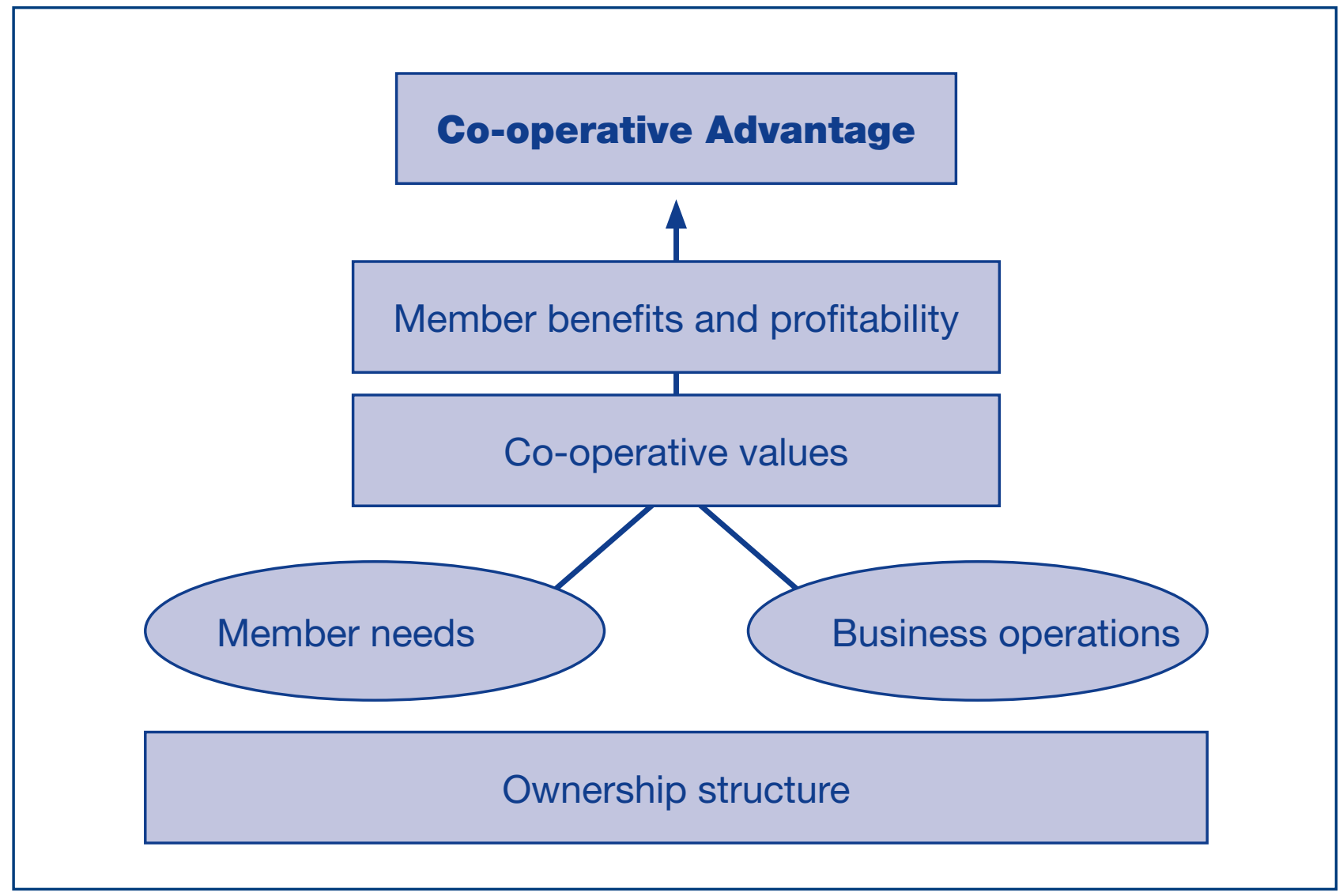

The foundation of a co-operative advantage is the ownership structure of the co-operative. This provides the basis upon which the co-operative can both address members' needs and operate a successful business. These two objectives are not mutually exclusive for they are aligned by the values, principles, and ethics of the co-operative (remember: co-operative values are human values). If done correctly, this leads to successful business outcomes (surplus) and satisfied 
members, which is the purpose of a co-operative. The co-operative has then created its co-operative advantage - that is, a USP that enables the business to compete with, and often outperform, traditional companies in its industry. Note the importance of surplus to a co-operative. A cooperative must balance member needs with the operation of a successful enterprise. Member benefits are enhanced and increased when the co-operative generates a healthy and sustainable surplus. The key distinction between co-operatives and conventional investor-owned businesses is the role of surplus; co-operatives are surplus focused but not surplus driven, while conventional businesses are profit driven and very often little else. The purpose of a co-operative is to satisfy its members; it does this best by creating a co-operative advantage.

\section{Making the most of a co-operative advantage}

Once a co-operative has understood the necessity of creating a co-operative advantage and has done so using the process outlined above, it is necessary to optimise the effect the advantage has on all of the operations of the co-operative. There are four steps to help a co-operative make the most of its advantage. ${ }^{18}$

Define

Deliver

Measure

Communicate
- Consult with your members and stakeholders to ascertain how they want their co-operative to be different and feed this into the process developed in the first section. For example, The Co-operative Bank's customers wanted the business to apply ethical considerations to their investment decisions. This in turn led to the creation of an ethical policy in 1992 outlining with whom the Bank will and will not do business.

- Embed this co-operative difference in every process in the business: marketing, production, human resources, strategic planning, customer services should all reflect this difference.

- Track the benefits the co-operative delivers to its members, customers, employees, local community, and other stakeholders. This requires more than just financial reporting; it involves a wide range of measures encompassing social, ethical and environmental objectives. Scotmid, Scotland's largest independent consumer co-operative, produces a social responsibility report that analyses the company's performance in terms of its Fairtrade objectives, staff training and development, member economic participation, and customer satisfaction, among other measures.

- Tell your members, stakeholders, employees, and the public the benefits your co-operative advantage provides. This in turn increases awareness of co-operatives amongst the public, generates additional revenue, and increases the membership. The process then reverts back to step one. ${ }^{19}$ 


\section{SEMINAR EXERCISE - Introduction to co-operative principles}

Materials to support this exercise can be found on the VLE.

1. Ask for two volunteers, and place one to your right and the other to your left. Tell the one on the left that he or she is the CEO of Apex Company and needs to hire (pick) four other students as employees.

2. Tell the one on your right that he or she is starting up the Combo Cooperative and must ask the students for anyone willing to join the cooperative as an equal member, stopping when four other students have joined.

3. Tell the CEO of Apex Company to think up an activity on his or her own to engage the employees. The CEO must then tell the employees to undertake that activity.

4. Tell the Cooperative group to decide amongst themselves what activity they want to engage in and then execute it. Give the teams about five minutes to get their acts together and another three or so minutes to demonstrate their activities.

5. Conclude the exercise and conduct the discussion segment.

\section{SEMINAR EXERCISE - The co-operative values and principles}

Materials to support this exercise can be found on the VLE.

The purpose of this exercise is to review the values and principles of co-operatives and to provide suggestions on how the principles could be updated if necessary.

1. Divide the participants into groups of roughly even number. The suggested size of each group is four to six participants.

2. Give each group a copy of the 'Values \& principles' document and ask them to read and digest the information for four to five minutes.

3. For the next ten to fifteen minutes, ask each group to complete the tasks required of them. Ask them to draw up their analysis using the materials provided.

4. When the tasks have been completed, ask each group to stick their flipchart paper containing their analysis on a wall and allow each group a couple of minutes to survey each group's work.

5. Conduct a discussion with all the participants on the reasons behind their analysis using your own insight and/or some of the discussion topics contained in the facilitator's note. 


\section{Summary of learning}

This chapter has argued that:

- Co-operatives and investor-owned businesses may appear to share some values in common, but it is the manner in which values are put into practice that makes co-operatives different.

- Co-operatives distinguish themselves from other forms of enterprises through their principles.

- The co-operative values and principles serve as a guide rather than strict rules for how these enterprises should act.

- The 'co-operative advantage' is crucial to the competitiveness of co-operative enterprises in the market.

\section{Essay/discussion questions}

- Are the co-operative principles developed by the Rochdale Pioneers still relevant today considering they were developed over a century ago during the Industrial Revolution? How can the Rochdale principles guide co-operatives in the complex and rapidly evolving twenty-first century economy in which they operate?

- Open and voluntary membership is a core principle of co-operative enterprises. With this in mind, how should co-operatives act with regards to employees or consumers who wish to work or trade with the co-operative but not become members? Is it right for a worker co-operative to continue to employ staff if they refuse to become members for instance?

- Which of the principles are unique to co-operative enterprises and which ones might be considered as general business practices?

- 'Creating a competitive advantage in business is crucial to ensure organisational success and sustainability.' Find examples and discuss how the process and elements of creating a competitive advantage are different for co-operative enterprises.

\section{Useful resources}

The International Co-operative Alliance - http://www.ica.coop/al-ica/.

The Fairtrade Foundation - http://www.fairtrade.org.uk/.

The Co-operative - Good with Money - http://www.goodwithmoney.co.uk/good-with-money/.

Business in the Community - http://www.bitc.org.uk/.

The Plunkett Foundation - http://www.plunkett.co.uk/.

The Equality Trust - http://www.equalitytrust.org.uk . 
1. International Co-operative Alliance (ICA), 'Statement on the Co-operative Identity'. http://www.ica.coop/coop/principles.html, accessed 4 May 2011. There are other definitions of what constitutes a co-operative. The following definition is generally adopted for co-operative research or study in the US: 'a cooperative is a user-owned, user-controlled business that distributes benefits on the basis of use.'

2. Birchall argues that the values can be divided into two separate groups: first order values (values that are ends in themselves) and second order values (values that are a means to an end). First order values are then broken down according to whether they are political (equality and solidarity) or ethical (honesty, openness, social responsibility and caring for others). J. Birchall, 'The Co-operative Values and Principles: A Commentary' Journal of Co-operative Studies 30 (1997): $42-69$.

3. Adopting an economic paradigm, Nilsson argues that that the values and principles play a key role in reducing transaction costs (costs that arise through the interactions between people) for members. The values help to reduce these costs between members while the principles do so between the co-operative and its members. J. Nilsson, 'The Nature of Cooperative Values and Principles: Transaction Cost Theoretical Explanations' Annals of Public and Cooperative Economics 67 (1996): $633-53$.

4. For further detail on the Rochdale Pioneers, see the accompanying case study for this chapter on the VLE.

5. Link4Life, 'Principles'. http://www.link4life.org/index.cfm?fuseaction=c.showPage\&pageID=324\&CFID=749830\&CFTOK EN=69816374, accessed 14 November 2011.

6. The Rochdale Pioneers are widely credited with creating the modern co-operative movement; while the model they pioneered was successfully replicated around the world, they were not the first co-operative to be established in Britain. The Fenwick Weavers, established in 1769 in the town of Fenwick, Scotland, are considered the earliest co-operative for which there are have full records. There are two case studies outlining the history of each co-operative society on the VLE.

7. There are examples of co-operatives, mainly agricultural, that assign more than one vote to members. A proportional voting system, based on the amount of trade a member does with the co-operative in a particular year, is supported by federal and state law in North America. There is a limit imposed on the number of votes a member can have, usually around ten.

8. In the US, federal and state statutes set a maximum of eight per cent dividend on capital subscribed. This has been mooted as a potential disincentive to invest in co-operatives over investor-owned businesses. However, UK retailer and employee-owned company John Lewis raised $£ 50 \mathrm{~m}$ in capital from its customers and investors through offering loan stock with a return of six per cent (in fact, there was much more interest in the scheme than the company had anticipated). A case study describing how John Lewis raised this capital can be found on the VLE.

9. W. Maxwell, A History of Co-operation in Scotland (Glasgow: Scottish Section of the Co-operative Union, 1910). The Lennoxtown society is mentioned on p. 52.

10. The threat of government interference in co-operatives appears to be resurfacing in Poland; a number of pieces of legislation were recently presented to parliament advocating government interference in the governance of all types of co-operatives, as well as legislation specific to housing co-operatives. Co-operative News. 'Attack on Poland's co-ops fought off'. http://www.thenews. coop/article/attack-poland\%E2\%80\%99s-co-ops-fought, accessed 14 November 11.

11. J. Voorhis, A New Look at Principles and Practices of Cooperatives (Washington: Cooperative League of the U.S.A, 1966$)$, p. 11.

12. The two most famous and successful examples are the Emilia Romagna region of Italy (see chapter 9 ) and the Mondragón worker co-operatives (see chapter 5) of the Basque country in Northern Spain.

13. Details of each of these initiatives can be found on the Co-operative Group's website: http://www.co-operative.coop/join-therevolution/our-plan/, accessed 4 May 2011.

14. There is a close affiliation between co-operative businesses and social enterprises. A social enterprise is a firm that is set up to achieve a social purpose through a successful business enterprise. While it is true to say that all co-operatives are social enterprises, because they are operated for the benefit of their members, not all social enterprises are co-operatives (jointly-owned and democratically-controlled).

15. K. Zeuli and R. Cropp, Cooperatives: Principles and Practices in the 21st century (Wisconsin: University of Wisconsin Center for Cooperatives, 2004), p. 45.

16. The Co-operative Bank, 'Why Do We Need Ethical Policies'. http://www.goodwithmoney.co.uk/why-do-we-need-ethical-policies/, accessed 4 May 2011.

17. P. Ghemawat and J. W. Rivkin, 'Creating Competitive Advantage' Harvard Business Review, 1998.

18. For a discussion of alternative strategies for creating a co-operative advantage see: R. Spear, 'Membership Strategy for Cooperative Advantage' Journal of Co-operative Studies 32 (2000): 102-23.

19. For further reading on the co-operative advantage see: T. Webb, L. Benander, L. Cirillo, and C. Lagier, Making the Most of Our Cooperative Advantage (Greenfield: Cooperative Life, 2006). 


\section{More than just profit: the co-operative business model}

'Cooperatives are a reminder to the international community that it is possible to pursue both economic viability and social responsibility.'

United Nations Secretary-General Ban Ki-moon

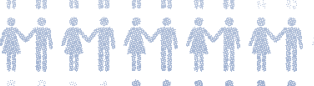

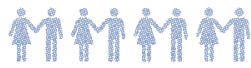

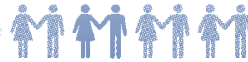

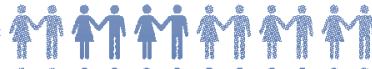

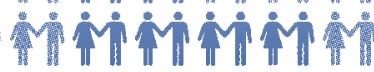

poivi ivi

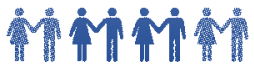

Mivip

in

i

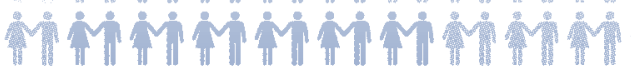

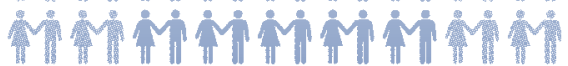

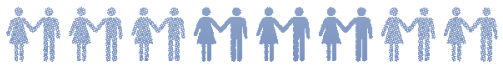

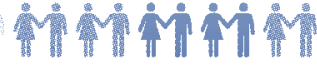

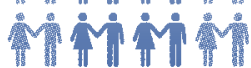

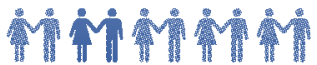

Mimin

寒i

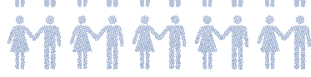

到

Min

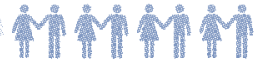

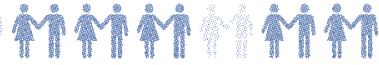
ำำ

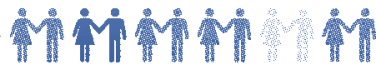

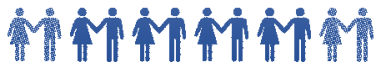
栾 M 


\section{More than just profit: the co-operative business model}

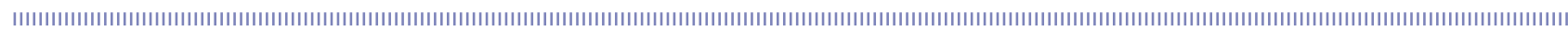

\section{Learning objectives}

This chapter explains the co-operative business model in terms of its unique ownership, governance, and beneficiary structure. It then shows how co-operatives use their distinctive characteristics to operate within the market and compares them with other models of enterprise. By the end of this chapter you will be able to:

- discuss the essential elements of the co-operative business model;

- compare and contrast the co-operative business model with other enterprise models;

- identify rights and responsibilities entailed in ownership of a co-operative.

The key arguments that will be developed in this chapter are:

Co-operatives exist for the purpose of providing maximum benefits to members by satisfying a defined common need.

Members own a co-operative on a collective rather than individual basis. Ownership of a cooperative is dependent on a member's willingness to support the business for the collective good rather than as the individual owner of private property.

Members of a co-operative are entitled to a share of any surplus (profit) generated in proportion to their patronage of the co-operative.

Capital is an instrument in a co-operative rather than a driver of business operations.

\section{Introduction}

Co-operative enterprises are member-based. This means they are:

- member-owned;

- member-controlled;

- distribute benefits (including surpluses) to members.

A member is someone who uses the services of the co-operative and agrees to accept the responsibilities of membership. Those responsibilities are chiefly to use the goods/services provided by the co-operative, provide capital for the business and participate in governance. For example, a user of a farm supply co-operative would be a farmer who purchases a tractor from the business; the user of a worker co-operative would be someone who works for the business. Only users of the co-operative's services are normally eligible to become members. ${ }^{1}$ 
The purpose of a co-operative is to provide maximum benefit to its members by engaging in economic activities or, to put it another way, by intervening in the market. ${ }^{2}$ Member benefits can be defined in economic, social, and psychological terms; there is usually a mix of these for most members. For example, a co-operative may provide food produce at low cost for its members, as well as supporting social initiatives in the member's community. This focus on providing maximum benefits of various kinds to members contrasts with the focus in the investor-owned model of enterprise where shareholder benefits are defined exclusively in economic terms. ${ }^{3}$

Under the headings member-owned, member-controlled, and member-beneficiary, we will now consider in more detail some of the distinguishing features of co-operatives.

\section{Member-owned}

\section{Owning shares... but differently}

Most co-operatives issue shares to their users, which must be purchased. But the shares do not operate in the same way as shares do in most investor-owned companies. These shares are often issued, and remain, at par value, meaning that the shares do not increase in value in proportion to the value of the business. The reason for this is to ensure that the co-operative focuses on providing the original benefit to members for which it was set up. There would otherwise be a risk of the co-operative being run mainly for the purpose of increasing the value of the shares (just like an investor-owned business). There would also be a danger of it becoming too expensive for new members to join as the value of the shares increased. Remember, membership of a co-operative is open, voluntary, and non-discriminatory.

Another crucial distinction between the shares in a co-operative and the shares in an investorowned company relates to the payment of interest on capital (known as a dividend in an investorowned company). In co-operatives, this payment is either limited, usually to around five per cent, or else forbidden altogether. Again, this is a measure to prevent the co-operative being run in the interest of capital rather than for the benefit of members. ${ }^{4}$ Most co-operatives only require a user to purchase one share to become a member. ${ }^{5}$ It is possible to purchase more than one share but, crucially, the amount of shares owned has no bearing on the member's right to participate in the governance of the business (one member/one vote as opposed to one share/one vote).

One final distinction that can be made between shares in a co-operative and the shares in an investor-owned business is the issue of transferability. It is usually impossible to transfer your share in a co-operative to another individual or organisation. ${ }^{6}$ This is because your membership reflects your ability to use the services of the co-operative, unlike shares in an investor-owned company which can be sold and inherited. ${ }^{7}$

\section{Rights}

As owners of the business, members of a co-operative are entitled to a number of accompanying rights. The list below discusses common ownership rights and how they relate to co-operatives. ${ }^{8}$ 


\section{Income rights}

Co-operatives assign income rights in relation to the member's right to a share of the surplus generated by the business (known as 'patronage refund') and the interest that is paid on member shares (if at all). This interest on shares is usually restricted to a defined percentage (five per cent is common) and not all the surplus generated is allocated to members: some is kept in the business in the form of retained earnings and some may be allocated to social/charitable initiatives.

\section{Voting rights}

These rights influence who can participate in decision making in the business. In co-operatives, these rights are held by the members on a one person, one vote basis.

\section{Transfer rights}

These rights pertain to the transfer shares in a business. Co-operatives tend to limit, if not forbid, the transfer of shares as a means of protecting the ownership structure of the company - that is, in order to keep the co-operative in members' hands. Shares are assigned to members as personal rights $^{9}$, similar to the right a citizen of a nation holds, and therefore cannot usually be transferred, inherited or bought by another individual or organisation. New members of a co-operative must purchase new shares rather than the shares of existing members.

\section{Information rights}

A company's articles of association will often include clauses relating to the access to information by owners. Most co-operatives will extend information rights to every member (echoing the fifth ICA principle) and ensure that information is presented in such a way that is useful to members (or to provide education to enable members to understand the information).

\section{Appreciation rights}

These rights determine whether the value of the company can be captured via the value of the shares held by owners. In co-operatives, shares are usually sold at par value and remain at this value throughout the duration of a person's membership. This is a measure to prevent the cooperative being run in the interests of capital to maximise the value of the shares rather than to satisfy members' needs.

\section{Liquidation rights}

Liquidation rights enable owners to dissolve a business in the event of insolvency. It is also possible, however, to liquidate a profitable business and to divide up the value and assets of the company amongst the owners. Co-operatives tend to limit the ability of members to dissolve the business for private gain by assigning the assets the status of common ownership. This means that no individual member has any claim to the assets of the business beyond the value of their shares, and in the event of dissolution the remaining assets of the co-operative are to be transferred to a similar business or to a charitable cause.

\section{Responsibilities}

Membership not only confers certain rights but also entails responsibilities, including the duty to ensure the co-operative is adequately financed. Members are the users of the business and so are responsible for its success, echoing the values of self-help and self-responsibility that all co-operatives espouse. Members typically provide finance to a co-operative in one of three ways:

- equity;

- debt;

- patronage (trade). 
It is possible for members to provide debt finance to the co-operative, but the most common, and important, means of financing is through equity. Usually, most of the equity will be contributed by members at the start-up stage of the co-operative's lifecycle to ensure that it is adequately financed to commence business operations. Besides this important function, member equity has three further uses:

- it helps to generate commitment and loyalty amongst members;

- it can act as collateral when securing debt finance;

- member equity can be used as a 'shock absorber' in times of financial crisis. ${ }^{10}$

\section{Member-controlled}

In a co-operative enterprise, the members play a significant role in governance, by which we mean the way in which the organisation is directed and controlled. The role of the members is to act as the final authority in governance matters. The members of a co-operative can exercise this right in two ways:

Directly $\quad$ - members can vote on issues at the annual general meeting (AGM) and any other general meetings that may be held. Policy and long-term business operations are typical issues that members are required to vote on directly.

Indirectly $\quad$ - members have the right to elect a board to represent their interests. The board can then hire a management team to look after the day-to-day operations of the business. ${ }^{11}$ The key point is that any governance body in a co-operative is accountable to the members, not another stakeholder group.

The concept of member control is slightly misleading in that it conjures an image of a business without any management hierarchy or one where every member votes on every decision. This is not usually the case, however. Member control means that the final authority lies with members, but generally that is exercised only at the AGM.

\section{Member-beneficiary}

Distribution of benefits on the basis of use describes the principle of proportionality, another key foundation for co-operatives. Members should share the benefits, risks, and costs of doing business in equal proportion to their patronage. It is an equitable system. ${ }^{12}$

The third element of our definition of a co-operative relates to how the members participate in the benefits (surplus) generated by the business, assuming this is contained within the rules. The concept of proportionality is central to the distribution of surplus in a co-operative enterprise. Members have a defined right to a share in any surplus generated by the co-operative on a proportional basis. The amount to which each member is entitled depends on the extent to which that member patronised the co-operative during a given year. The amount that a member receives is called the 'patronage refund'. ${ }^{13}$ 


\section{Patronage refund}

The patronage refund is calculated annually and is the amount of surplus, if there is one, to which an individual member is entitled through his or her use of the co-operative. This entitlement comes from the idea that the co-operative has overcharged its members for goods/services during the year and members are owed a rebate (similarly a worker co-operative could be said to have underpaid its members). The word patronage refers to the use or trade an individual member conducts with the co-operative - so those who contributed the most to the success of the business are rewarded proportionally. A member's entitlement to a share of the surplus of the co-operative is one of the fundamental rights of ownership.

\section{Process}

The process of determining how to return this surplus to members will now be explained.

Step 1 - Decide how much of the surplus is to be allocated for patronage refund. Co-operatives will need capital in the form of retained earnings as a buffer against cash flow needs or possible future losses, as well as for investment purposes such as purchasing new buildings or collateral for a loan. The formula for deciding how much of the surplus is retained differs for each co-operative and much depends on the capital requirements of the business. Also, the amount of surplus that was generated from non-members may be a factor in this decision; members in some US co-operatives do not have any entitlement to surplus generated by the trade of non-members.

\section{Step 2 - Calculate each member's contribution to the surplus.}

This can be done relatively simply using the amount of trade a member conducted with the co-operative in a given year. For consumer co-operatives, this figure can be the amount of goods or services a member purchased; for worker co-operatives, it can be the amount of hours worked or their salary. Once each member's contribution is calculated, the principle of proportionality can be applied. An individual member's share of the surplus is calculated by expressing their patronage (trade) for the year as a percentage of the total patronage (in other words, total sales). So a member with $£ 4,000$ of patronage, when the business had $£ 40,000$ worth of sales, would be entitled to ten per cent of the surplus available for distribution to members.

\section{Step 3 - Decide how much of the patronage refund should be in cash.}

As a way of retaining capital in the business, co-operatives often defer the payment of some of the refund to members for a number of years. Using the previous example, the member entitled to ten per cent of the surplus available for distribution (say £100) might only receive twenty per cent of this in the form of cash, with the other eighty per cent being deferred for a period of time. This deferred amount would usually be held in the member's capital or equity account, and can be thought of as a loan by the member to the co-operative. Although most co-operatives operating this system do not pay interest on the deferred patronage refund, there are examples of those who do and we shall discuss one in a later chapter. 
Figure 2-Example of surplus allocation (after tax) in a co-operative

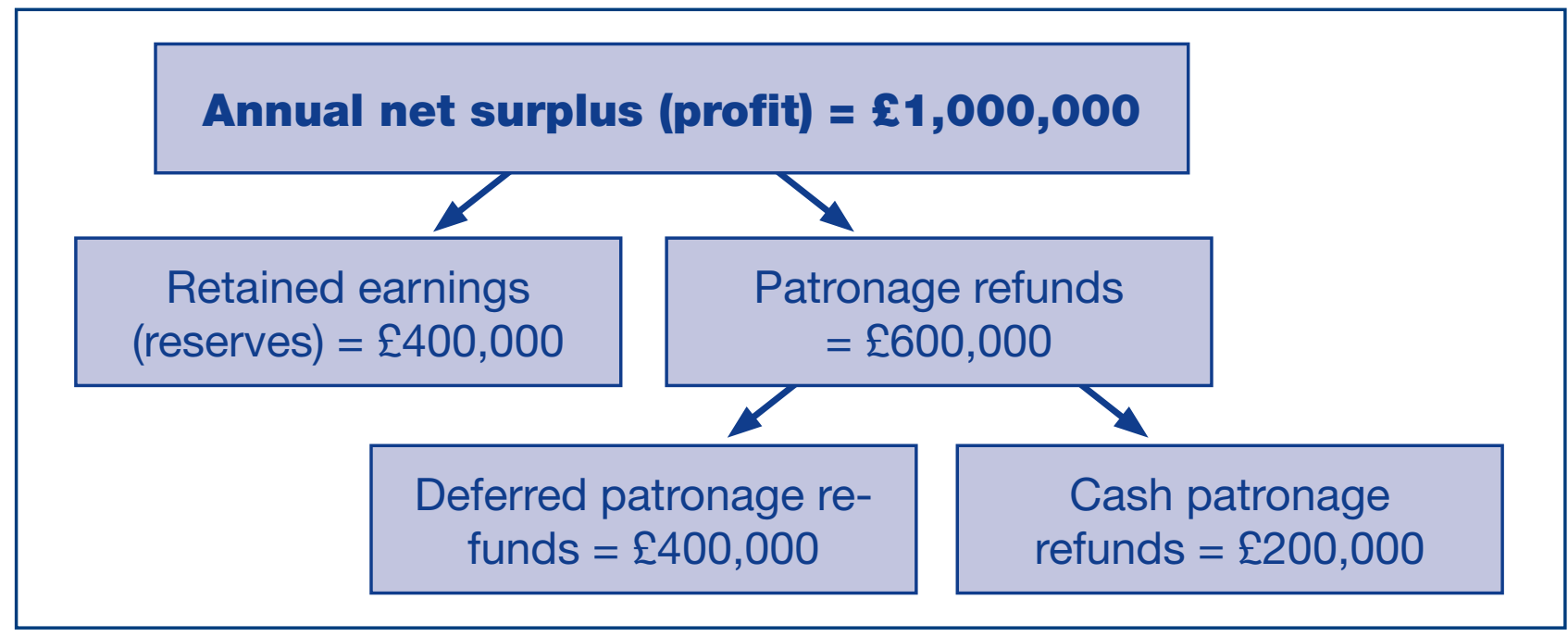

\section{Demonstration}

In order to demonstrate the process of determining patronage refunds, we will use the example of a fictional retail co-operative, Drumchapel Food Co-op. The co-operative has ten members and sells basic groceries. At the end of 2011, the co-operative generated a surplus of $£ 20,000$ on sales of $£ 100,000$. The board of directors have decided to retain $£ 10,000$ of this surplus as retained earnings as there was quite a lot of trade with non-members throughout the year. Of the $£ 10,000$ available for distribution to members, the patronage refund was calculated as set out in the table below.

Table 2-Sample patronage refund calculation

\begin{tabular}{|c|c|c|c|}
\hline Member & $\begin{array}{c}\text { Amount of groceries } \\
\text { bought }(\boldsymbol{f})\end{array}$ & $\begin{array}{c}\% \text { of Total Sales to } \\
\text { Members }\end{array}$ & $\begin{array}{c}\text { Share of Surplus } \\
\text { (surplus * \% of Total } \\
\text { Sales) } £\end{array}$ \\
\hline A & 2,500 & $5 \%$ & 500 \\
\hline B & 7,500 & $15 \%$ & 1,500 \\
\hline C & 5,000 & $10 \%$ & 1,000 \\
\hline D & 3,750 & $7.5 \%$ & 750 \\
\hline $\mathrm{E}$ & 5,000 & $10 \%$ & 1,000 \\
\hline F & 1,250 & $2.5 \%$ & 250 \\
\hline G & 10,000 & $20 \%$ & 2,000 \\
\hline $\mathrm{H}$ & 6,250 & $12.5 \%$ & 1,250 \\
\hline I & 1,250 & $2.5 \%$ & 250 \\
\hline $\mathrm{J}$ & 7,500 & $15 \%$ & 1,500 \\
\hline
\end{tabular}




\section{The co-operative business model}

The term 'business model' has many connotations and meanings but few agreed definitions. ${ }^{14}$ By business model, we are referring to the economic underpinning of a business, encompassing all of the activities that contribute to the economic success of the enterprise..$^{15}$ This is the traditional interpretation of what a business model is but, as we have seen, a co-operative has unique characteristics that affect the way in which it does business. Co-operatives therefore have a particular business model, one that is based on satisfying member needs.

The co-operative business model has three core elements: the values and principles, the memberbased structure of the business, and the business processes relevant to the type of industry in which the co-operative operates. Each one of these elements is dependent on the other two. For instance, satisfying member needs can only be exercised with respect to the set of values and principles that guide the co-operative's actions. Where all of these elements meet on a productive basis, a competitive advantage over other forms of enterprise is created.

Figure 3-The co-operative business model

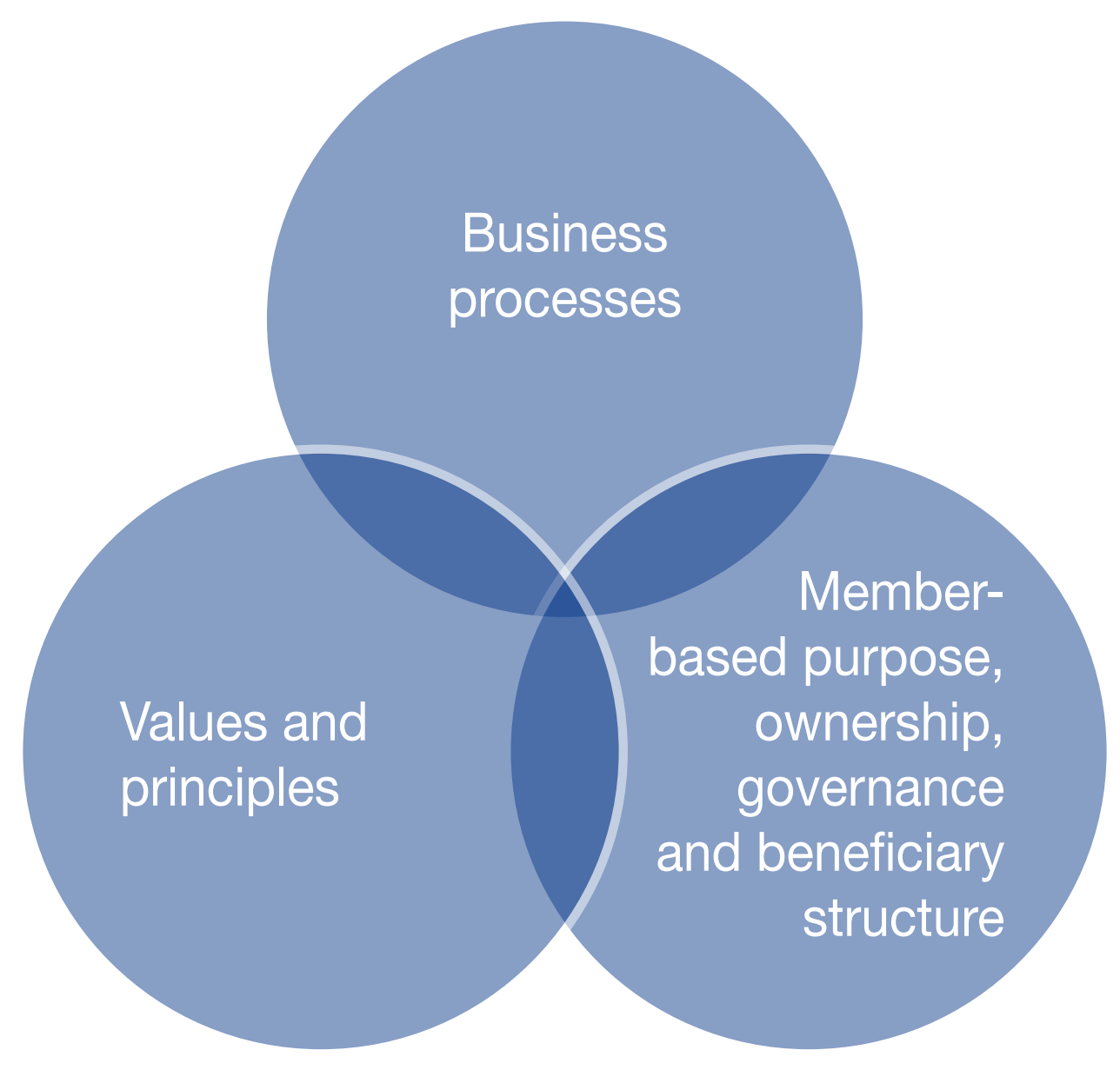

\section{Business model elements}

To further our analysis of a co-operative business model, we must examine how the model operates in practice. It is helpful here to use a framework common to all organisations. ${ }^{16}$ 


\section{Revenue model}

Revenue is the lifeblood of any company; without it, there ceases to be a business. A company's revenue model is concerned with several fundamental questions. Who will buy your product? What will they buy? How soon, often, and how much will they buy? The unique business model of co-operative enterprises, based on internationally agreed values and principles, affects how these questions are answered for a co-operative.

For instance, some revenue streams (customers) are not compatible with the ethics and values of some co-operatives. The Co-operative Bank's ethical policy, discussed in chapter 1, meant that it withheld over $£ 1 \mathrm{bn}$ of funding to potential customers, denying the business significant amounts of revenue in the form of interest. Yet a co-operative's values and principles can also open up new revenue streams that have the advantage of sustainability. Graphics.coop, a worker co-operative based in Edinburgh, Scotland, works with a diverse range of clients but it gives priority service to the co-operative, environmental, and charitable sectors. This allows graphics.coop both to target clients that are often overlooked by the market and to develop a leading share of a niche market. Media co-op, an independant film and digital production business, based in Glasgow, has a similar revenue model. Although it makes documentaries for broadcast companies, such as the $\mathrm{BBC}$ and $\mathrm{Al}$ Jazeera, on issues that chime with its values and principles, Media Co-op's core work is specifically with organisations that share the same values and ethics.

What these examples show is that a co-operative's values are of central importance to its revenue model. The values influence the co-operative's decisions about who it will or will not do business with, and those values cannot be ignored by the members involved in managing the co-operative.

\section{Gross margin model}

Gross margin is the amount a business earns when it sells a product or service at a price that exceeds what it costs to produce and deliver the product or service. In accounting terms, it is sales less 'cost of goods sold' (COGS). Earning a gross margin is crucial for a business to not only cover its operating costs but also make a healthy profit. Therefore, a company's gross margin model is concerned with selling a product or service for as much as the customer is willing to pay and keeping the costs (for example the price of raw materials involved in making the product) as low as possible.

For a co-operative business, it is not always possible or desirable to develop a gross margin model based on the two concerns outlined above, since to do so might conflict with its values. Other concerns might take priority. For example, The Co-operative Group's food stores have been supporters of the Fairtrade movement for over eighteen years, stocking the first Fairtrade certified coffee, Cafédirect, in their stores in 1992. Under the Fairtrade certification, producers of primary goods such as coffee and bananas are guaranteed a price higher than the market price. The price paid has on occasion been double or even triple the global market price. In 2003, The Co-operative Group switched all of its own brand coffee to Fairtrade, a move praised by those in the Fairtrade movement. ${ }^{17}$ In business terms, however, the Group increased its cost of goods sold, reducing its gross margin on its own brand coffee. Not only that, but the group pledged to keep its prices competitive so as to encourage customers to purchase Fairtrade products. The Co-operative has gone one step further in 2011 by stating in its future operating plan that if any product 'can be Fairtrade, it will be Fairtrade'. ${ }^{18}$

The Co-operative Group's actions have shown that the pursuit of a healthy gross margin does not have to take precedence over a company's values and principles. The Group accepted a decline in its gross margin for the sake of ensuring others in the supply chain were paid a fair price. Such actions contrast with the more common scenario whereby other large retailers relentlessly drive down their cost of goods sold by 'squeezing' their suppliers for the lowest price possible. ${ }^{19}$ 


\section{Operating model}

Operating costs may be defined as all the other daily costs that are incurred in addition to the costs of goods sold. A company will have operating costs relating to labour, lighting and heating, premises and other elements that are fundamental to the successful operation of the business. It is therefore in a company's interests to reduce or eliminate as many of its operating costs as possible.

How then, might a co-operative's values and principles affect its operating model? This issue is best explored in relation to one of the most crucial operating costs a business incurs - and one which, conversely, is also one of the first costs it seeks reduce when constructing its operating model namely the cost of labour.

The worker co-operatives of Mondragón Corporation have implemented a system whereby labour costs can never be eliminated. A worker co-operative that subscribes to Mondragón must commit to a rule that states that no worker-member can be made redundant. This commitment to labour produces some interesting situations and issues during times of poor financial performance.

When the global financial crisis took hold in 2009, Mondragón members voted for a nine per cent reduction in salary rather than making any workers redundant. This ensured that Mondragón protected the welfare of its worker-members by reducing business costs and ensuring sustainability.

Some years ago, Orbea, who manufacture high specification bicycles and related accessories, were suffering financially and were over staffed. In accordance with Mondragón rules, half of Orbea's 150 worker-members were transferred to another co-operative until the company had sufficiently recovered, when the worker-members then returned to Orbea. Mondragón has created a safety net for its worker-members, ensuring that protecting the value and rights of labour is the foremost priority of each co-operative and the organisation as a whole. ${ }^{20}$

There are of course other operating costs that every business, whether investor-owned or co-operative, seeks to reduce or eliminate, such as energy, waste and maintenance.

\section{Working capital model}

Often overlooked and marginalised in favour of the other elements, working capital is vital to ensure that a company can survive day to day and cover the costs of operating. Mullins and Kumisar define it as the cash a company needs in the short-term to keep the business running. ${ }^{21}$ A company's working capital relates to the ability of current assets to cover current liabilities, preferably with some cash left over. The 'Holy Grail' is to develop a negative working capital model, that is, the business gets in money faster than it has to pay it out. This can be achieved by negotiating generous credit terms with your suppliers and forcing customers to pay up front or even in advance.

What most businesses do not consider though is the wider economic and social impact of a negative working capital model. In 2003, Debenhams, one of Britain's most recognisable and successful retailers, was bought by private investors and taken off the stock market. Soon afterwards, the company renegotiated its credit terms with suppliers. Debenhams went from paying its suppliers every twenty-seven days to paying them every two months. ${ }^{22}$ This freed up huge amounts of cash for the business as the suppliers were effectively granting Debenhams an interest free loan. Such a policy could be argued to do more harm than good to society. The flow of cash is restricted and the financial burden is transferred from a large retailer to, in many cases, a small supplier.

Co-operatives have been aware of this 'beggar thy neighbour' approach to working capital for years and have devised inventive solutions to counteract this problem. One of the earliest examples of an effective and equitable working capital model was devised by the Rochdale Society of Equitable 
Pioneers. One of the core principles of the enterprise was to sell to members on a cash basis only; no credit terms were offered. This not only ensured that payment for goods occurred at the point of transaction - thereby contributing immediately to working capital and ensuring the business remained in liquidity - but it also prevented their members from becoming burdened by debt, a common problem around the time of the Industrial Revolution.

One of the more exploitative practices that arose in towns and cities across Britain as a result of the Industrial Revolution was the 'truck' system. Private shop owners often held a monopoly in factory towns and exploited villagers by providing poor quality goods at high prices. Shop owners also colluded with factory owners to ensure local workers were paid in tokens that could only be used in their shops; as a result many villagers became indebted to the factory and shop owners.

This section has demonstrated that the co-operative values and principles even influence the approach a co-operative business has to its cash-flow strategy, usually in contrast to its conventional business competitors.

\section{Investment model}

Capital is a vital element in every business. It is instrumental in the establishment of a company and essential for financing projects, expansion, and daily functions when the business is in operation. A company's investment model therefore is concerned with how much capital is needed for the business, who the capital will be sourced from, and at which points in its development the business may need an injection of capital.

The traditional method for raising capital for a new business is by selling shares in the company to investors. Since the risk of the business failing is quite high, investors will demand a significant share in the business in terms of ownership and control, along with a decent dividend (you can see this played out in the TV show Dragon's Den). This method of raising capital is not an option for co-operatives because ownership and control of the business reside with members and cannot be transferred (although some co-operatives have raised capital by issuing non-voting shares). The following two examples demonstrate the innovation displayed by co-operatives in seeking access to capital to finance their enterprises.

\section{Example 1: Raising capital to establish the business}

The Mondragón worker co-operatives have developed a systematic approach for raising capital for new businesses. The first co-operatives found it difficult to access capital as traditional banks were unwilling to deal with an organisation where everyone was an owner. To resolve this issue, three of the co-operatives formed the Caja Laboral Popular bank in 1959 to raise funds in the form of deposits from the community, thus providing access to finance not only for existing co-operatives but also for new ones. By 1963, Caja Laboral had provided finance for twenty cooperatives and has continued to do so right up until the present day. Usually, the bank provided sixty per cent of the start-up capital with the founding members providing twenty per cent with the remaining twenty per cent coming from a state fund. ${ }^{23}$

\section{Example 2: Raising capital once the business has been established}

In the mid 2000s, Manchester-based Unicorn Grocery, one of Britain's largest worker cooperatives, faced losing its store to property developers. Since the co-op's formation in 1996, it had rented premises in South Manchester and quickly expanded. Revenues grew from $£ 3,500$ to $£ 3.5 \mathrm{~m}$ in the space of a decade and membership grew from four to fifty. Faced with the seemingly imminent sale of the property from under them, Unicorn members realised that the best way to secure the co-op's future was by purchasing the building themselves. To do this, they needed to raise $£ 350,000$. Rather than turning to institutional or private investors, Unicorn issued $£ 350,000$ worth of loan stock which was purchased by their customers. This enabled the business 
to complete the purchase of the property and protect the ownership and control structure of the co-operative. ${ }^{24}$

These two examples highlight some of the difficulties co-operatives face compared with investorowned firms when trying to access capital. The traditional method of raising capital through selling shares to outside investors is usually not an option and banks are less inclined to support co-operatives. Many co-operatives therefore seek capital either from their members (who, under current UK legislation, can invest up to $£ 20,000$ in the business) or from specific loan funds, such as those operated by Co-operative and Community Finance. ${ }^{25}$

\section{EXERCISE - What is a business model?}

\section{Part 1 -}

In your own terms, what do you think a business model is? Try and define the concept in a paragraph or less. Having done that, what do you think are the essential elements of a business model?

\section{Part 2 -}

Watch the video at the link below and answer the following questions:

1. What do you think a co-operative business model is?

2. How does it compare to your definition of a traditional business model? Are there any similarities between the elements?

Video: http://www.youtube.com/watch?v=96EOrGPJfk8 (start at 3:28) 


\section{The co-operative business model compared with other enterprise models}

The table below provides a basic framework for understanding how co-operatives differ from other organisational models, namely the investor-owned company and the social enterprise. ${ }^{26}$

Table 3-Comparison of enterprise models

\begin{tabular}{|c|c|c|c|}
\hline & Co-operative & $\begin{array}{l}\text { Investor-owned } \\
\text { Company }\end{array}$ & Social Enterprise \\
\hline Purpose & $\begin{array}{l}\text { Improve the quality of life } \\
\text { for members }\end{array}$ & $\begin{array}{l}\text { Create wealth } \\
\text { for shareholders }\end{array}$ & Achieve a social purpose \\
\hline Ownership & Members & Shareholders & $\begin{array}{l}\text { Usually a community, } \\
\text { charity or quasi- } \\
\text { governmental body. } \\
\text { Sometimes owned by } \\
\text { individual entrepreneur }\end{array}$ \\
\hline Control & $\begin{array}{l}\text { Democratic basis - } \\
\text { one member, one vote }\end{array}$ & $\begin{array}{l}\text { Property right basis - } \\
\text { one share, one vote }\end{array}$ & $\begin{array}{l}\text { Trustees or equivalent } \\
\text { group that may or may not } \\
\text { be democratically elected }\end{array}$ \\
\hline Beneficiary & Members & Shareholders & Target social group \\
\hline $\begin{array}{l}\text { Financed by } \\
\text { (excluding } \\
\text { debt finance) }\end{array}$ & $\begin{array}{l}\text { Member contributions and } \\
\text { retained earnings }\end{array}$ & $\begin{array}{l}\text { Sale of shares and retained } \\
\text { earnings }\end{array}$ & $\begin{array}{l}\text { Retained earnings and } \\
\text { grants }\end{array}$ \\
\hline $\begin{array}{l}\text { Motivational } \\
\text { driver }\end{array}$ & $\begin{array}{l}\text { Self-help and self- } \\
\text { responsibility }\end{array}$ & Personal wealth creation & Altruism or public policy \\
\hline $\begin{array}{l}\text { Market- } \\
\text { oriented }\end{array}$ & $\begin{array}{l}\text { Yes - market intervention } \\
\text { to benefit members }\end{array}$ & Yes & Yes \\
\hline $\begin{array}{l}\text { Distribution } \\
\text { of surplus }\end{array}$ & $\begin{array}{l}\text { Three methods: } \\
\text { - Members } \\
\text { - Reinvested in the business } \\
\text { - Allocated to social/charitable } \\
\text { initiatives }\end{array}$ & $\begin{array}{l}\text { Yes in form of dividend } \\
\text { related to shareholding }\end{array}$ & $\begin{array}{l}\text { Not to individuals, } \\
\text { usually reinvested in the } \\
\text { enterprise }\end{array}$ \\
\hline $\begin{array}{l}\text { Distribution } \\
\text { of assets on } \\
\text { dissolution }\end{array}$ & $\begin{array}{l}\text { Yes - usually to members; } \\
\text { however, controls can be put } \\
\text { in place to prevent individual } \\
\text { members benefiting from the } \\
\text { liquidation of the co-operative }\end{array}$ & Yes - to shareholders & $\begin{array}{l}\text { No- usually passed onto } \\
\text { another community } \\
\text { benefit company or social } \\
\text { enterprise }\end{array}$ \\
\hline
\end{tabular}

Source: Adapted from E. Parnell, (2011). Enterprise Models ${ }^{27}$ 


\section{SEMINAR EXERCISE - Co-operate to succeed}

Materials to support this exercise can be found on the VLE.

The purpose of this exercise is to discover participants' ability to be co-operative or competitive in response to their environment and situation.

1. Divide the students into four groups (or more depending on the number of participants). Each group represents a department in the company.

2. Explain the rules of the exercise to each group.

3. Allow the groups to discuss their decision for the first week for a short while (two or three minutes). Go around to each group and ask them their decision. Record the decision and repeat for the other groups.

4. Once each group has made a decision, announce the results of the week to all of the groups (e.g. 2 Black, 2 Red), record the results for each group and the company asa whole, and begin the next week.

5. Repeat steps 2 and 3 until you reach the end of the fourth week. Ask each group to appoint a representative and allow each representative to discuss the state of the company. Allow a few minutes before sending them back to their groups.

6. The week after representative meetings is a bonus round where all of the scores are multiplied (see worksheet).

7. Repeat steps $2-4$ until the end of week 12.

8. Announce the results of the exercise, with the decisions made by each group and the amount of profit or loss of the company.

9. Conclude the exercise by conducting a short discussion on the importance of co-operation and shared goals/objectives for organisational success.

\section{SEMINAR EXERCISE - The meaning of ownership}

Materials to support this exercise can be found on the VLE.

The purpose of this exercise is to explore the roles capital and labour play in the ownership of enterprises and also the effect each has on the distribution of rewards.

1. Divide the students into a number of groups depending on class size. It is not important how many members there are in each group but try to keep them evenly spread.

2. Run through the PowerPoint presentation until you get to the 'The Decisions' slide. At this point, ask the students to debate the decision to be made for a number of minutes (at the discretion of the facilitator but we recommend a minimum of five minutes).

3. When the students have finished debating, ask them to vote for one of the five options and record the results on the separate PowerPoint presentation.

4. Move onto the next decision and repeat the process: debate, vote, and record.

5. When the groups have finished making their decisions and the votes have been recorded, show the participants the results and conduct the discussion segment of the exercise. 


\section{Summary of learning}

This chapter has argued that:

- Co-operatives are member-based organisations; their purpose is to satisfy member needs rather than to maximise the return on capital employed.

- Co-operatives seek to maximise member benefits through the achievement of one or more objectives.

- Members own a co-operative on a collective rather than individual basis. Ownership of a cooperative is dependent on a member's willingness to use the business.

- Members of a co-operative are entitled to a share of any surplus generated in proportion to their patronage of the co-operative.

- Capital is an instrument in a co-operative rather than a driver of business operations.

\section{Essay/discussion questions}

- 'Co-operative enterprises will find it difficult to raise finance from external sources.' Analyse the factors that would contribute to this perceived difficulty.

- Did the Rochdale Pioneers' 'no credit policy' demonstrate concern for community in terms of not wanting citizens to get into debt or was it the opposite, showing a complete lack of concern for community by disregarding those who might not have cash resources to trade?

- 'An organisation's business model is affected by its values, principles and ethics.' Discuss this statement with reference to multiple organisational forms (investor-owned, co-operatives, and social enterprises).

\section{Useful resources}

Scottish Agricultural Organisation Society - http://www.saos.co.uk/.

National Cooperative Business Association - http://www.ncba.coop/.

Co-operatives UK - http://www.uk.coop.

Understanding the Cooperative Business Model - http://vimeo.com/6o81590.

Global co-operative statistics - http://www.ica.coop/coop/statistics.html.

The Cooperative Curriculum - http://cooperative-curriculum.wikispaces.com/.

There is an Alternative - http://www.vimeo.com/22896857.

United Nations Year of Co-operatives 2012 - http://social.un.org/coopsyear/. 
1. There are examples of co-operatives that allow investors to become members, though it is not common. Ethical Consumer, a consumer research organisation, has both consumers and investors as members of the co-operative (this combination of two membership classes is known as a hybrid or 'multi-stakeholder' co-operative).

2. D. I. Bateman, J. R. Edwards, and C. Levay, 'Agricultural Cooperatives and the Theory of the Firm' Oxford Agrarian Studies 8 (1979): 63-81. See p. 77.

3. K. Zeuli and R. Cropp, Cooperatives: Principles and practices in the 21 st century (Wisconsin: University of Wisconsin Center for Cooperatives, 2004), p. 46.

4. D. A. Frederick, 'Co-ops 101: An Introduction to Cooperatives' Cooperative Information Report 55 (US Department of Agriculture, 1997), chapter 2.

5. The value of that share is specific to each co-operative. For example, the Co-operative Group only requires £1, while Mondragón co-operatives requires $€ 8,000-14,000$. In each case, members are responsible for providing capital and only receive one share in return. Members can also contribute capital in the form of loans (an option prevalent in small worker co-ops).

6. Some co-operatives have a model where shares can be transferred e.g. Energy4All co-operatives and some agricultural co-operatives. There are, however, conditions placed on who can benefit from such transfers.

7. It is possible for co-operatives to sell non-voting shares to external investors but the lack of participation in decision-making, as well as the limited return on investment, makes investing in a co-operative unattractive. Efforts have been made to improve the attractiveness of co-operatives to investors: the Financial Services Authority (FSA) now allows non-user investors to hold up to $25 \%$ of the votes in a co-op, for example see www.somerset.coop.

8. R. Ridley-Duff, M. Bull, and P. Seanor, Understanding Social Enterprise: Theory and Practice (London: Sage, 2011), pp. 147-8.

9. The concept of personal and property rights is discussed in chapter 3.

10. M. A. Abrahamsen, Cooperative Business Enterprise (New York: McGraw-Hill, 1976), p. 291.

11. The situation is sometimes different in a worker co-operative where the members both govern and manage the business themselves. Worker co-operatives who govern and manage themselves this way are known as 'collectives'.

12. Zeuli and Cropp, Cooperatives: Principles and practices in the 21st century, pp. 1-2.

13. A member's share of the surplus is known as a dividend in the UK and as a patronage refund in the US and Canada. To prevent confusion with the dividend associated with an investor-owned business, this text will use the term 'patronage refund'.

14. J. Margretta, 'Why Business Models Matter' Harvard Business Review May 2002; A. Osterwalder and Y. Pigneur, Business Model Generation: A Handbook for Visionaries, Game Changers, and Challengers (Hoboken: John Wiley \& Son, 2010).

15. J. Mullins and R. Kumisar, Getting to Plan B: Breaking Through to a Better Business Model (Boston: Harvard Business School Press, 2009), p. 5.

16. Mullins and Kumisar, Getting to Plan B: Breaking Through to a Better Business Model.

17. 'Co-op moves to Fairtrade coffee' BBC News 13 November 2003. http://news.bbc.co.uk/1/hi/business/3264671.stm, accessed 19 April 2011.

18. 'The Fairtrade Foundation welcomes the Co-operative's new ethical operating plan' Fairtrade Foundation press release 18 February 2011. http://www.fairtrade.org.uk/press_office/press_releases_and_statements/february_2011/the_fairtrade_ foundation_welcomes_the_cooperatives_new_ethical_operating_plan.aspx, accessed 22 April 2011.

19. The Group's embracing of the Fairtrade movement is part of its long-term business strategy, which is to appeal to a wide-range of consumers on both ethical and economic grounds.

20. R. Ramesh, 'Basque Country’s Thriving Big Society' The Guardian 30 March 2011.

21. Mullins and Kumisar. Getting to Plan B: Breaking Through to a Better Business Model, p. 135.

22. D. Erdal, Beyond the Corporation: Humanity Working (London: The Bodley Head, 2011), p. 104.

23. A. Campbell et al, Worker-Owners: The Mondragón Achievement (London: Anglo-German Foundation for the Study of Industrial Society, 1977), p. 44.

24. Unicorn Grocery, 'Our History’. http://www.unicorn-grocery.co.uk/history.php, accessed 15 April 2011.

25. There have been changes to the UK legislation; see chapter 4 for a more in depth analysis of IPS law.

26. For a more detailed discussion of co-operative business models in relation to the investor-owned business, see: F. R. Chaddad and M. L. Cook, 'Understanding New Cooperative Models: An Ownership-Control Rights Typology' Review of Agricultural Economics 26 (2004): 348-60. This article develops a typology of co-operative business models that exist between the traditional co-operative form of enterprise and the investor-owned business. The authors draw some interesting conclusions from this typology, particularly in relation to the distribution of ownership rights in these organisations.

27. E. Parnell, 'Enterprise Models'. http://www.co-oppundit.org/enterprise_models.html, accessed 20 May 2011. 


\section{...of the people, by the people, for the people: co-operative governance}

'If liberty and equality, as is thought

by some, are chiefly to be found in

democracy, they will be best attained

when all persons alike share in

government to the utmost.'

Aristotle

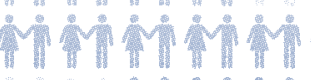

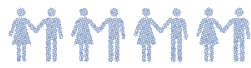

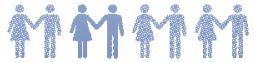

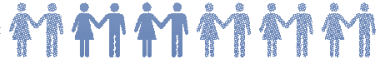

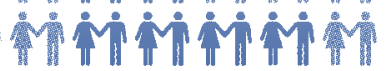

poivi ivi

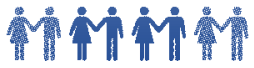

Mivip

in

in

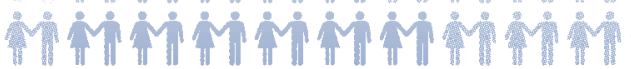

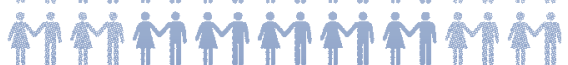

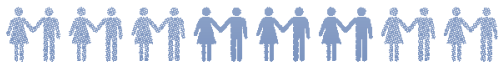

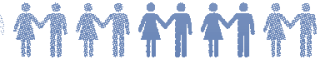

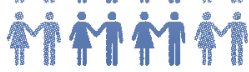

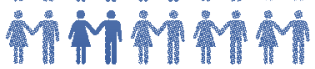

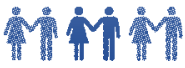

în

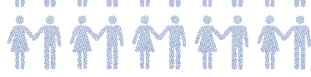

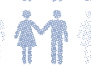

Min

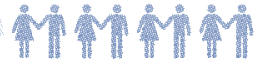

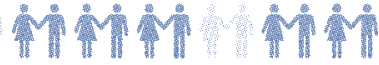
Mํํำ

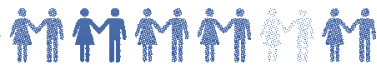

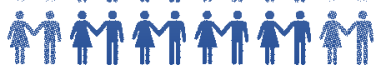
章 Min 


\section{3. ... of the people, by the people, for the people: co-operative governance}

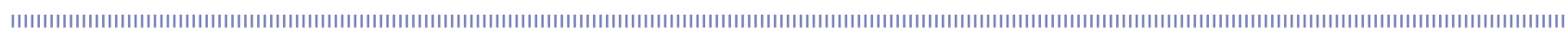

\section{Learning objectives}

This chapter introduces some of the key aspects to effective governance of co-operative enterprises. Co-operatives are member-owned and for this reason they need a system of governance that places members at the core of the business. Generation of a healthy surplus is crucial to co-operative governance because without economic viability there is nothing for the members to own or control. By the end of this chapter you will be able to:

- outline the core elements of co-operative governance;

- analyse the application of democratic theory of governance in co-operative enterprises;

- explain the relationship between the roles of members, management, and the board of directors in a co-operative.

\section{The key arguments that will be developed in this chapter are:}

Co-operative governance is based on a system of personal rights, rather than property rights which is the case in an investor-owned company.

Members can exercise their right to participate in governance by voting directly on long-term business decisions and policy, as well as electing a board of directors to represent member interests. Election is conducted on a one member/one vote basis.

The effective governance of a co-operative is dependent on the members, board of directors, and management working together to achieve the co-operative's objectives.

Education, training and information are vital for members to be able to participate effectively in the governance of the co-operative.

\section{What is governance?}

Owing to prominent corporate scandals in $2000-1$, as well as the increasing size and complexity of publicly-owned organisations, corporate governance has been widely discussed in recent years. Broadly defined, corporate governance refers to 'the structures, processes, cultures and systems that engender the successful operation of the organisation'. ${ }^{1}$ In essence, corporate governance is concerned with ensuring that the objectives of the organisation are achieved in a manner that is acceptable to the owners. The following notions are central to any form of corporate governance: 
- The purpose of the organisation is vital in determining an appropriate system of governance.

- An effective system of corporate governance must balance the needs of accountability and performance.

- Good corporate governance must be based on principles rather than prescription. ${ }^{2}$

- Good corporate governance is as much about supporting and enabling management as it is about directly controlling their behaviours. ${ }^{3}$

\section{Co-operative governance}

The most important asset to a co-operative is its members. ${ }^{4}$ Therefore, co-operatives place their members at the core of their governance structure, just as investor-owned companies place shareholders at the core of theirs. In one sense, there is not much difference between shareholder value theory, which states that an investor-owned company should be directed towards generating maximum value for its shareholders, and a co-operative's attempts to direct its resources to satisfy member needs and provide maximum benefits. It is the manner in which these organisational theories are formalised in their respective corporate governance structures that distinguishes co-operatives from investor-owned companies.

The most important aspect of co-operative governance is the effective relationship between the two core functions of the organisation:

- democratic participation (association)

- operations management (enterprise)

Of course it is very unlikely that these two functions will always be held strictly in balance or that they will never come into conflict. ${ }^{5} \mathrm{~A}$ more accurate assessment of the relationship between the two functions is provided by Kleer who argues that, in the medium to long-term, there will be conflict between the interests of the co-operative (economic expansion) and the interests of members (extensive participation). ${ }^{6}$ Generally the interests of one function will supersede the interests of the other during periods in the co-operative's existence.

Figure 4 illustrates the governance system of a typical co-operative. ${ }^{7}$ It shows that members wield ultimate authority and can directly influence the operations of the business by clearly defining their needs and communicating them via participation in govenance. 


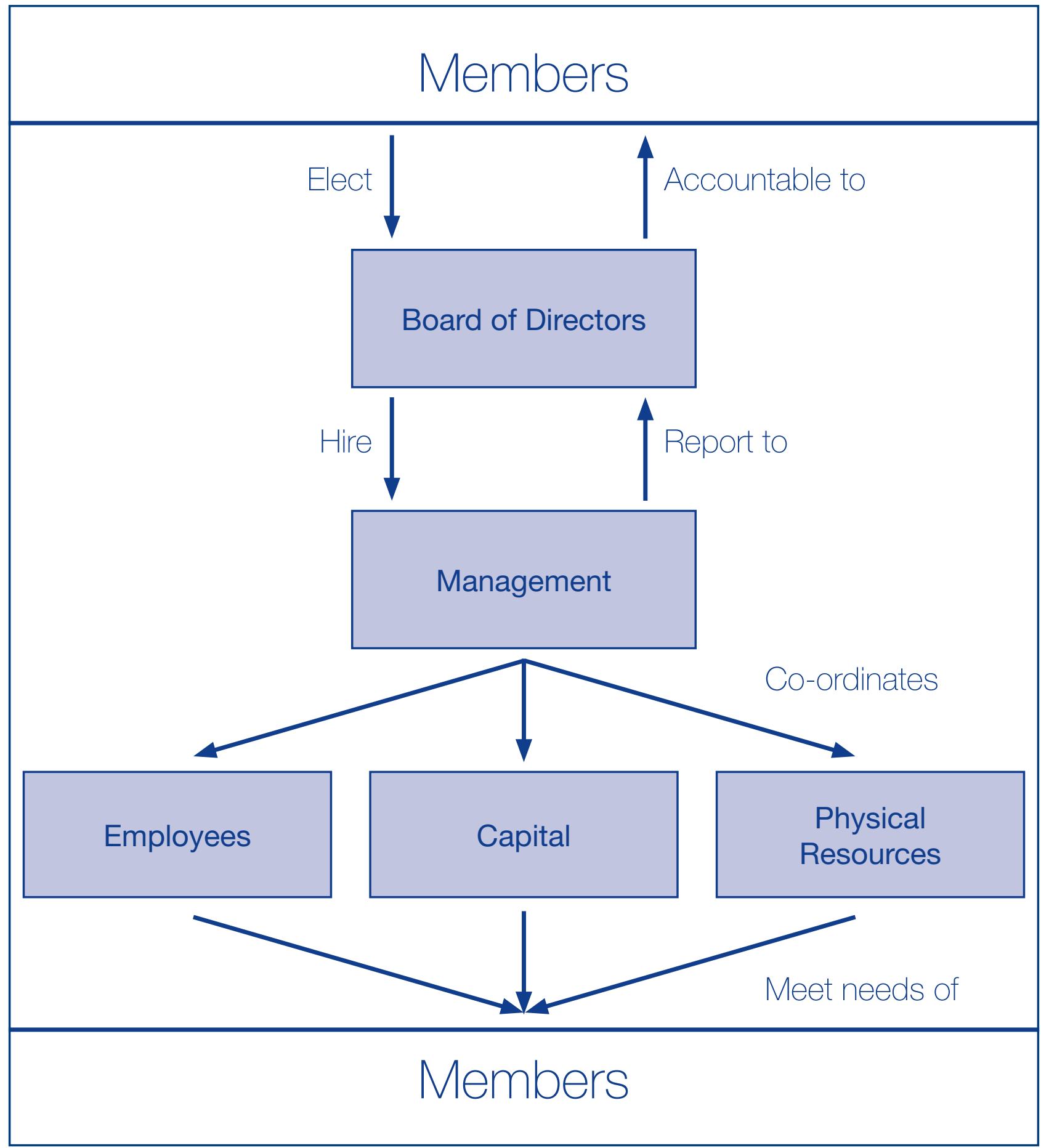

\section{Democratic theory of governance}

Democratic theory asserts that ultimate control rights in an organisation lie with those who are directly affected by the operations of the enterprise. In the case of co-operatives this means the members. A democratic system of governance is based on the concept of personal rights as opposed to property rights in investor-owned firms.

A personal right, in this context, is a right that belongs to an individual because the person satisfies some objective criterion; for example, he or she plays a functional role in the organisation or uses the goods and services of the business. In a democratic election, a person is normally granted 
a right to vote only when they are a citizen of that country. Co-operatives have adopted a system of governance based on personal rights. ${ }^{8}$ This is opposed to the system of property rights in investor-owned companies where voting is conducted on a one share/one vote basis.

It is vital that those who are entrusted with rights in an organisation are willing and able to accept the responsibilities that such rights entail. ${ }^{9}$ In the case of co-operatives, member participation in governance is a fundamental responsibility which comes from having the right to exercise democratic control over the business.

\section{EXERCISE - Democratic theory of corporate governance}

In the YouTube video at the link below, David Brown outlines one of the many theories relating to corporate governance including the one adopted by co-operatives, the democratic theory of governance. In his opinion, democratic governance leads to poor performance and a lack of organisational sustainability. Watch the video and consider the following questions:

1. To what extent are you convinced by Brown's argument that democratic governance will neglect the interests of the firm?

2. What factors affect the choice of a corporate governance theory for a firm? Consider the purpose and ownership structure of the business.

3. 'Brown's argument is supported by the legal view of an organisation as profit maximising in order to provide the greatest return to shareholders. Hence his assertion that democratic governance will lead to a deviation from the interests of the firm (profit maximisation). He does not legislate for other forms of organisation, ones that are profit making but not profit maximising.' Do you agree with this statement? What evidence is there to support Brown's argument?

Video: http://www.youtube.com/watch?v=cEsPXA7pMNA

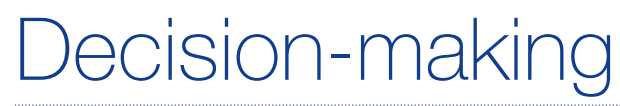

Co-operatives involve a wide-range of people in the decision-making and management process. Members work with the board of directors to make decisions regarding policy in the co-operative. The board works closely with the senior management team to develop strategic goals and objectives for the business. It is essential that all three groups - members, management, and the board of directors - work together effectively and understand their own and each other's responsibilities.

\section{Deciding how to decide}

It is vitally important that the members of a co-operative explicitly state how decisions are to be made. This decision-making process can be formally stated in the co-operative's governing document or else informally agreed by all members. The latter approach only works if there are very few members (and even then may break down in the event of conflict). The key point regarding the choice of an appropriate decision-making process is that the decision to use it must be possible using that same process..$^{10}$ For instance, if decisions in the co-operative are to be made via majority voting, then the members must agree to this by a majority vote (that is, a majority of members must accept majority voting). The same goes for any of the other forms of decisionmaking that can be used in co-operatives, as outlined below. ${ }^{11}$ 
Consensus $\quad$ - everyone needs to agree on a matter before a decision can be taken. While this may seem to be the purest form of decision-making, relying on persuasion and discussion, it can be difficult to implement because it runs the risk of members reaching a decision that nobody wanted (compromise rather than consensus). On the other hand, co-operatives are founded upon the members having a common interest, and consensus decision-making may be the best method of reinforcing this mutuality. Consensus decision-making can be especially difficult to implement in co-operatives with a large membership base.

Simple majority - for a decision to be taken, more than fifty per cent of the voting members must be in favour of a particular outcome. This method is generally quicker than consensus as there is no need for discussion or persuasion. A simple majority, however, can alienate a large proportion of the membership and the cooperative can, in theory, be controlled and run for the benefit of slightly more than half of the members.

Supermajority - requires a proportion of the membership exceeding a simple majority to vote in favour of a decision. It is at the discretion of the co-operative as to what this proportion may be. Decisions reached by this method are potentially fairer because they account for a large majority of members, though there is still the possibility of alienating a small section of the members. There is also the possibility of decisions being blocked by a minority of members. Supermajority decision-making is a better process for preventing the creation of factions within the co-operative. Supermajority voting is usually only specified for major decisions such as amending the name, rules or objects of the co-operative.

\section{Speed and quality of decision-making in co-operatives}

It is often argued that decision-making in co-operative enterprises is considerably slower than in other organisations, and therefore represents a competitive disadvantage. The slowness is attributed to the participatory nature of governance and the need to get members 'on side' when making a decision. An empirical study of fourteen co-operatives in the US confirmed that co-operatives do take longer to make decisions than other forms of enterprise. ${ }^{12}$ The argument that labels slower decision-making as a competitive disadvantage, however, can be countered by introducing the concept of quality. Despite taking longer to make decisions, it can be argued that the decisions produced by the co-operative are of a higher quality as a result of a consultative and participatory governance structure; these decisions have been subject to a greater degree of scrutiny, using the knowledge of all of the members involved. In this paradigm of decision-making, co-operatives can be thought to have a competitive advantage over other forms of enterprise. The key point is that any decisions taken by the members, managers, and board of directors must balance the needs of democratic participation with the needs of the organisation.

\section{The importance of the governing document}

Co-operatives UK describe a governing document as:

a record of the governance arrangements of an organisation, typically detailing the purpose of the organisation and its relationship both to its members and to the outside world. ${ }^{13}$ 
The document is a valuable resource for it clearly states how members can exercise their voting rights in the governance of the co-operative. Typically, a co-operative's rules will contain details pertaining to the admission of members, the functions of the board, how meetings should be conducted, and other related governance issues. The rules of a co-operative should be accessible via the body with which it is registered (in the UK this could be the Financial Services Authority or Companies House) or by contacting the co-operative.

\section{The role of the members, board and management}

The effective governance of a co-operative is dependent on the members, board of directors, and management working together to achieve the co-operative's objectives. ${ }^{14}$ There are three key aspects to ensure these groups function interdependently:

- each group needs to understand its roles and responsibilities;

- there needs to be effective communication between all three groups;

- each group needs to regularly engage in the governance system of the co-operative.

Table 4 below represents the most common and important responsibilities of each group.

Table 4-Responsibilities of governance participants

\begin{tabular}{|l|l|}
\hline Group & Responsibilities \\
\hline Members $^{15}$ & $\begin{array}{l}\text { Understand the co-operative: its purpose, objectives, structure, operations, } \\
\text { benefits and limitations. } \\
\text { Elect, remove and evaluate directors. } \\
\text { Assist in the formulation of policy } \\
\text { Provide necessary capital. } \\
\text { Patronise the co-operative. } \\
\text { Participate in decision-making. } \\
\text { Provide information. } \\
\text { Help obtain new members. }\end{array}$ \\
\hline Board of directors ${ }^{16}$ & $\begin{array}{l}\text { Formulate policies acceptable to members. } \\
\text { Hire the general manager (CEO) and hold them accountable. } \\
\text { Set long-term business objectives. } \\
\text { Evaluate the performance of the co-operative. } \\
\text { Act collectively not individually. } \\
\text { Source and manage capital. }\end{array}$ \\
\hline Management ${ }^{17}$ & $\begin{array}{l}\text { Put into action the policies decided by the board. } \\
\text { Serve the best interests of the members. } \\
\text { General management functions. } \\
\text { Report to the board. } \\
\text { Hire employees. }\end{array}$ \\
\hline
\end{tabular}


Owing to the interrelationship of each group's responsibilities, communication within co-operatives must be continuous, effective, and involve all three groups. ${ }^{18}$

\section{The role of the members}

There are actions that the board of directors and the management can take to facilitate greater member involvement in governance. First, both parties must ensure that members have access to information relating to the co-operative's objectives, policies, and operations. Second, both parties must ensure that there are sufficient opportunities (outside of mandatory opportunities such as the AGM) for members to participate in the running of the co-operative.

In a similar way to shareholders in investor-owned companies, the members of the co-operative have the ability to fulfil their governing role via three mechanisms: voice, vote, and exit. Voice represents the way in which members can influence decision-making and policy in the co-operative by expressing their views to the board and management. Members can also fulfil their role by voting on major decisions. Finally, members can usually exit the co-operative without difficulty. Since member shares are usually non-transferable, there are few barriers preventing a member exiting the business, which then places the onus on the co-operative to recruit new members. ${ }^{19}$ Member exit poses a greater risk to the co-operative than shareholder exit does to an investorowned firm, because the shares held by members can be withdrawn. That is, the equity capital supplied by members to the co-operative can be reclaimed when a member leaves the co-operative. As a result, the threat of exit can be an effective way of reinforcing the co-operative's purpose to the board and management.

\section{The role of the board}

Nearly all co-operative enterprises will have a board of directors to oversee the operations of the business and ensure the co-operative is directed towards achieving its objectives. ${ }^{20}$ It is generally much too cumbersome and inefficient for every member to make every decision regarding the co-operative's strategy and policies hence the need for a board of directors. The members of a co-operative's board of directors are elected from the membership; the election of directors occurs at the AGM.

The board of directors in a co-operative has two main roles:

- represent member interests;

- provide strategic direction for the enterprise.

Like the two main functions of a co-operative enterprise, the relationship between both roles must be managed, and equilibrium can be difficult to achieve. Whilst the democratic nature of governance in co-operatives tends to ensure that board members fulfil the first role, it is not always the case that board members will possess the knowledge, skills, and abilities needed to drive the business forward. Adequate training and education opportunities should be provided to prospective and newly appointed board members to ensure they can fulfil both roles. Table 5 below outlines some of the issues co-operative board members must address as part of their dual role. 


\begin{tabular}{|c|c|}
\hline $\begin{array}{l}\text { Democratic } \\
\text { theory }\end{array}$ & $\begin{array}{l}\text { This is the formal governance model that co-operatives and mutuals adopt. } \\
\text { Democratic theory of governance is based on the concept of the board acting } \\
\text { as representatives of the members and includes core principles such as one } \\
\text { member/one vote, open elections, and accountability to the membership. } \\
\text { The representatives that serve on the board of a co-operative are elected from } \\
\text { the general membership. }\end{array}$ \\
\hline Agency theory & $\begin{array}{l}\text { This is the model that is most common in private companies around the } \\
\text { world (particularly the US and UK). Corporate governance based on agency } \\
\text { theory is concerned with the board's role in ensuring managerial compliance. } \\
\text { The theory asserts that the interests of owners and managers differ and } \\
\text { a mechanism is needed to ensure that managers act in the best interests } \\
\text { of shareholders. In relation to co-operatives, it is essential that the board } \\
\text { ensures that managers are acting in the best interests of members. }\end{array}$ \\
\hline $\begin{array}{l}\text { Stewardship } \\
\text { theory }\end{array}$ & $\begin{array}{l}\text { This theory assumes that those who control the organisation (managers) want } \\
\text { to do a good job acting as stewards of the organisation's resources. Stewardship } \\
\text { theory promotes a partner-style working relationship between the board and } \\
\text { management. The role of the board is to add value in terms of strategic decision- } \\
\text { making to support management. This means that board members must possess } \\
\text { some expertise in relation to the company's operations. }\end{array}$ \\
\hline $\begin{array}{l}\text { Resource } \\
\text { dependency } \\
\text { theory }\end{array}$ & $\begin{array}{l}\text { This theory of governance is based on the idea that the organisation is dependent } \\
\text { on its external environment for its resources. The role of the board is to maintain } \\
\text { effective relationships with stakeholders to ensure there is a flow of resources in } \\
\text { and out of the organisation. Board members must possess external contacts and } \\
\text { expertise to function effectively in relation to resource dependency theory. }\end{array}$ \\
\hline $\begin{array}{l}\text { Stakeholder } \\
\text { theory }\end{array}$ & $\begin{array}{l}\text { Stakeholder theory states that an organisation should be governed in the } \\
\text { interests of multiple stakeholders. This theory requires boards to effectively } \\
\text { manage conflict arising between different stakeholders. }\end{array}$ \\
\hline $\begin{array}{l}\text { Managerial } \\
\text { hegemony } \\
\text { theory }\end{array}$ & $\begin{array}{l}\text { This theory asserts that managers effectively control organisations and the } \\
\text { role of the board is merely to approve the decisions taken by management. } \\
\text { While managers may be considered best placed to exercise control in the } \\
\text { organisation, it is vital that the board is able to exercise power and influence } \\
\text { over management when required. For co-operatives, this theory presents the } \\
\text { danger of member interests being usurped by those of management. }\end{array}$ \\
\hline
\end{tabular}

Source: Adapted from C. Cornforth, 'Making sense of co-operative governance: Competing models and tensions' Review of International Co-operation 95 (2002): 51-7.

Each of the above theories is applicable to the boards of co-operatives. Cornforth argues that the board of a co-operative must not function according to just one theory. He highlights four key areas in which the simultaneous roles of a board may cause tension:

- The role of the board as representatives and experts.

- The role of the board in driving performance and ensuring conformance.

- The role of the board in controlling and supporting management.

- The accountability of the board to members and other stakeholders. ${ }^{21}$ 


\section{The role of management}

The primary role of managers in a co-operative is to implement the strategic objectives of the business through the management of day-to-day operational activities. Management, in cooperation with the board of directors, is responsible for ensuring the co-operative realises its purpose or mission. The activities managers pursue must be in the best interests of members.

The management training provided in business schools does not usually cater for the distinct competencies that are required to manage a co-operative successfully. In an analysis of core management competencies for consumer co-operatives, Tuominen, Jussila and Rantanen identified eleven elements of managerial competence. Despite their focus on consumer co-operatives, many of these competencies apply equally to the management of producer and worker co-operatives.

Table 6-Elements of managerial competence in consumer co-operatives

\begin{tabular}{|l|l|}
\hline Type of competence & Specific elements \\
\hline Knowledge & $\begin{array}{l}\text { Information and understanding of co-operative value-based } \\
\text { management }{ }^{22} \\
\text { Information and understanding of customer interface management } \\
\text { Information and understanding of multi-business management } \\
\text { Information and understanding of community development }\end{array}$ \\
\hline Attitude & $\begin{array}{l}\text { Identification with co-operative values } \\
\text { Readiness to speak out }\end{array}$ \\
\hline Skill & $\begin{array}{l}\text { Co-operative value-based management skills } \\
\text { Customer interface management skills } \\
\text { Community development skills } \\
\text { Collective and participative decision-making skills } \\
\text { Visionary leadership skills }\end{array}$ \\
\hline
\end{tabular}

Source: P. Tuominen, I. Jussila, and N. Rantanen, 'Managerial Competence in Consumer Co-operatives: Inducing theory from empirical observations' International Journal of Co-operative Management 5 (2010): 9-22. 
Ortega outlines seven variables or factors that influence the probability of a co-operative being successfully managed:

Table 7-Factors that influence the success of co-operative management

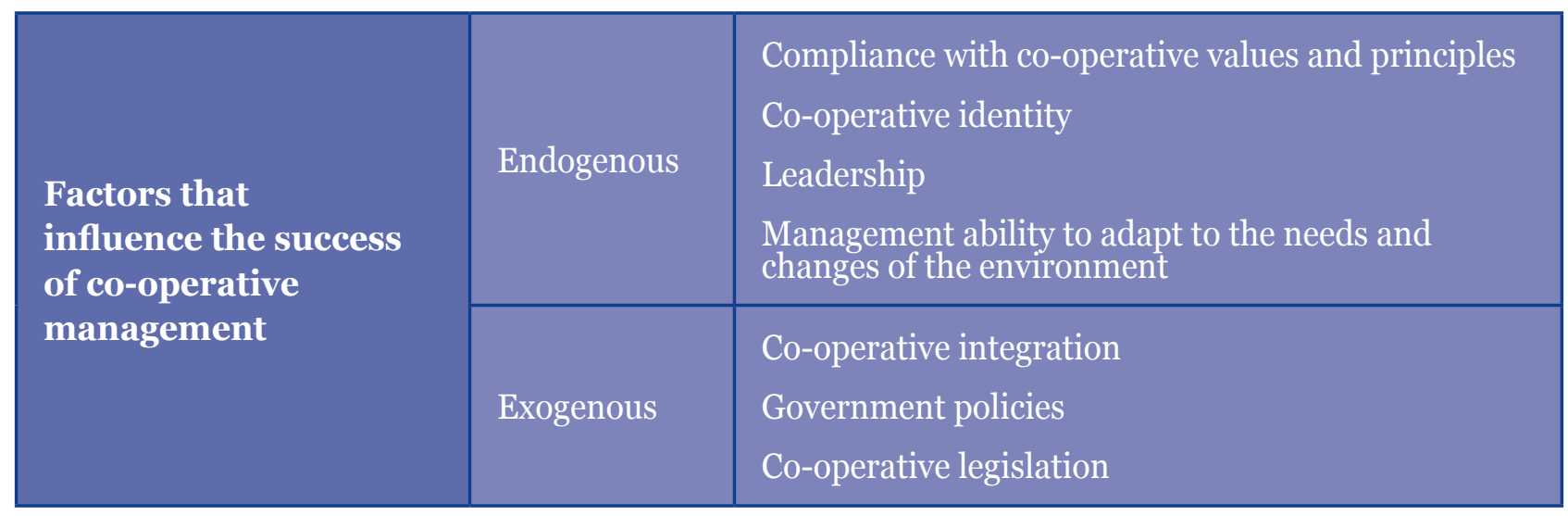

Source: P. O. Ortega, 'Agricultural Co-operation in Spain. Developing research goals and a literature review on the issue of success factors for co-operative management applied in the case of an olive oil co-operative, The International Journal of Co-operative Management 5 (2O10): 46-53.

These seven success factors need to be married with an effective corporate governance structure. Every organisation needs managers who are competent and principled, but this in itself is not sufficient to ensure the enterprise is run in a way that is acceptable to the owners. A robust corporate governance structure coupled with engaged owners is the best way of ensuring that the organisation operates appropriately. There are examples of co-operatives or mutuals that were 'hijacked' by their managers and converted to private companies or public limited companies (note in particular the surge in privatisations of mutual organisations, particularly building societies, in the early 1990s). ${ }^{23}$ It should not be assumed that the values and principles are enough to ensure that management acts in the best interests of members: an informed and engaged membership is just as important. ${ }^{24}$

\section{Importance of engagement and participation}

Members must understand their rights and responsibilities and have appropriate incentives to participate. ${ }^{25}$ Birchall and Simmons propose that member involvement and participation can be motivated by three factors, known as collectivistic incentives:

- shared goals;

- shared values;

- sense of community. ${ }^{26}$

A sensible membership strategy is needed in order for a co-operative to engage successfully with its members. ${ }^{27}$ 


\section{SEMINAR EXERCISE - Democratic decision-making}

Materials to support this exercise can be found at the VLE.

The purpose of this exercise is to engage students in various methods of democratic decisionmaking and ensure they understand the process, issues and outcomes of each method.

1. Divide the students into groups based on the decision-making process they will use i.e. majority and consensus. The number of participants in each group is entirely up to the facilitator; we recommend that the majority group is uneven in number and the consensus group even in number.

2. Assign the students in each group their role. The two roles are senior and junior. For the majority group, assign more students the role of senior employee than junior employee. With the consensus group, assign an even number of roles:

Senior Employee - With the company >2 years

Junior Employee - With the company <2 years

3. Record the time it takes each group to reach their decision and what their decision is.

4. When the groups have finished making their decision, conduct the discussion segment of the exercise.

\section{Summary of learning}

This chapter has argued that:

- Co-operative governance is based on a system of personal rights rather than property rights which is distinct from the system in an investor-owned company.

- Members can exercise their right to participate in governance by voting directly on major business decisions, as well as electing a board of directors to represent member interests. This is conducted on a one member/one vote basis.

- The effective governance of a co-operative is dependent on the members, board of directors, and management working together to achieve the co-operative's objectives.

- Education, training, and access to information are vital for members to be able to participate effectively in the governance of the co-operative.

\section{Essay/discussion questions}

- Should the board of a co-operative be accountable to the interests of non-member groups?

- How would a co-operative go about addressing the tensions that can arise in the role of the board?

- Are there difficulties keeping members engaged when a co-operative becomes very large? 
- Why is democracy not widespread in corporations, but is nonetheless something we strive for in society (and for which people in some countries sacrifice their lives)?

- 'Co-operatives will find it impossible to satisfactorily manage the relationship between member participation and control, and the business requirements of the co-operative.' Discuss this statement with respect to your study of co-operative governance.

- Does the free market economy facilitate democracy or is it the other way around? Are co-operatives a way of bringing democracy to the market?

\section{Useful resources}

UK Corporate Governance Code - http://www.frc.org.uk/corporate/ukcgcode.cfm.

University of Wisconsin Co-operative Governance resources -

http://www.uworker co-operativec.wisc.edu/issues/Governance/index.aspx.

Co-operantics - http://www.cooperantics.co.uk/.

SAOS best practice guide to governance -

http://www.saos.co.uk/home/documents/SAOSCGEFFP.pdf.

Co-operatives UK codes of practice -

http://www.uk.coop/tags/resources/Codes\%20of\%2opractice.

\section{Endnotes}

1. K. Keasey, S. R. Thompson, and M. Wright, Corporate Governance: Economic, Management and Financial Issues (Oxford: Oxford University Press, 1997), p. 2.

2. K. Keasey, H. Short, and M. Wright, 'The Development of Corporate Governance Codes in the UK' in K. Keasey, S. R. Thompson, and M. Wright (eds), Corporate Governance: Accountability, Enterprise and International Comparisons (West Sussex: John Wiley \& Sons Ltd, 2005), p. 22.

3. Keasey, Short, and Wright, 'The Development of Corporate Governance Codes in the UK', p. 23.

4. K. Zeuli and R. Cropp, Cooperatives: Principles and practices in the 21 st century (Wisconsin: University of Wisconsin Center for Cooperatives, 2004), p. 4.

5. From Conflict to Co-operation is a series of five cartoon booklets from Co-operatives UK which aims to help enterprises not only deal with conflict when it arises but also avoid unnecessary conflict. The five topics covered include how to recognise and deal with conflict; communication skills; meetings and decision-making; organisational growth and development; and the role and responsibilities of the committee. The booklets can be accessed at http://www.uk.coop/fromconflict2co-operation.

6. J. Kleer, 'The Co-operative System - Between Participation and Growth' in E. Dulfer and W. Hamm (eds), Co-operatives: In the Clash Between Member Participation, Organisational Development and Bureaucratic Tendencies (London: Quiller Press, 1985), pp. 372-3.

7. This diagram is slightly different for worker co-operatives as the employees are also the members; this results in greater member participation in day-to-day management and operational activities.

8. D. P. Ellerman, The Democratic Worker-Owned Firm (London: Unwin Hyman, 1990), p. 52.

9. R. Ridley-Duff and M. Bull, Understanding Social Enterprise: Theory \& Practice (London: Sage, 2011), p. 130.

10. A. McLeod, 'Deciding how to Decide' Cooperative Starter Series \#4. Northwest Cooperative Development Center, 2008.

11. Other methods of decision-making include autocracy, consultative, and unanimity. Each of these methods, including those mentioned in the body of the text, form a continuum of decision-making processes, with autocracy at one end and unanimity at the other. See the article at http://cultivate.coop/wiki/Deciding_how_to_decide for more information on the topic.

12. B. M. Henehan and B. L. Anderson, Decision Making in Membership Organisations: A Study of Fourteen U.S. Cooperatives (New York: Cornell University, 1994), p. 74.

13. Co-operatives UK. Simply Governance (Manchester: Co-operatives UK, 2011), p. 18. 
14. Ontario Cooperative Association, 'Co-operative Board \& Governance Part 1'. http://www.youtube.com/watch?v=1RUb463Up0w\&f eature=related, accessed 16 June 2011.

15. United States Department of Agriculture. 'Cooperative Member Responsibilities and Control' Cooperative Information Report 1 , Section 7, 1990. pp. 5-10.

16. M. A. Abrahamsen, Cooperative Business Enterprise (New York: McGraw-Hill, 1976), p. 264.

17. Abrahamsen, Cooperative Business Enterprise, p. 266.

18. Zeuli and Cropp, Cooperatives: Principles and practices in the 21 st century, p. 54.

19. In certain co-operatives, the withdrawal of shares is at the discretion of the directors of the business.

20. There are legal requirements pertaining to the election, role and liabilities of co-operative board members. These requirements are a product of the legislation under which co-operative enterprises must register. See chapter 4 for a discussion of co-operative legal forms.

21. C. Cornforth, 'Making Sense of Co-operative Governance: Competing Models and Tensions' Review of International Co-operation 95 (2002): 51-7.See p. 52. For further details of Cornforth's co-operative governance theory: C. Cornforth, 'The Governance of Cooperatives and Mutual Associations: A Paradox Perspective' Annals of Public and Cooperative Economics 75 (2004): 11-32.

22. Davis corroborates this requirement for co-operative managers to be grounded in the co-operative values and purpose. He argues that only through such managers can the aims and objectives of co-operatives at a macro level be realised. P. Davis, 'Management Development for Co-operatives: A Review' Journal of Co-operative Studies 29 (1997): 53-68.

23. A recent example in Scotland was Musselburgh and Fisherrow Co-operative near Edinburgh. In 2007, at the second attempt, the board of the co-operative converted the business to a private limited company.

24. The inspiration for this analysis of the importance of member participation over principled management was drawn from an article by Andrew Hill entitled 'It's the managers, not the model' published in the Financial Times. Hill advocates that there is no model of governance superior to another: 'But to argue that one vehicle for business activity is inherently better than another is a little like saying a four-wheel-drive is always safer and faster than a tandem. Whether it conveys its occupants securely and speedily to their destination surely depends on who is steering it.'

25. R. J. Ridley-Duff, 'Communitarian Governance in Social Enterprises: Case Evidence from the Mondragón Cooperative Corporation and School Trends Ltd' Social Enterprise Journal 6 (2010): 125-45. See p. 145.

26. J. Birchall and R. A. Simmons, 'What Motivates Members to Participate in Co-operative and Mutual Businesses?' Annals of Public \& Cooperative Economics 75 (2004): 465-95. See p. 472.

27. For a review of the factors influencing democratic participation in co-operatives: J. Rothschild and R. Russell, 'Alternatives To Bureaucracy: Democratic Participation In The Economy' Annual Review of Sociology 12 (1986): 307-28. For an analysis of how co-operative and mutual organisations incorporate member interests into the democratic governance structure and the factors influencing the power of managers in these organisations: R. Spear, 'Governance in Democratic Member-Based Organisations' Annals of Public and Cooperative Economics 75 (2004): 33-60. 


\section{Co-operative societies in society: classifications and incorporations}

'Cooperatives, as economic

enterprises and as self-help

organizations, play a meaningful

role in uplifting the socio-economic

conditions of their members and their

local communities.'

United Nations

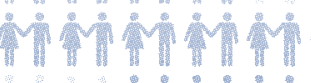

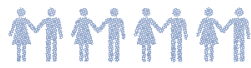

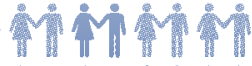

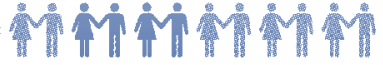

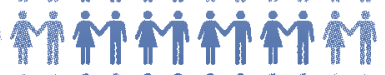

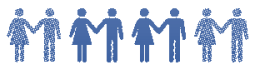

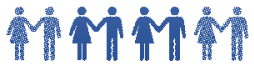

Mimp

11

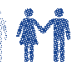

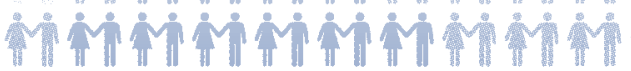

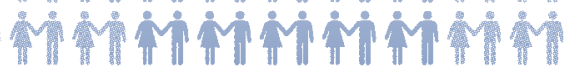

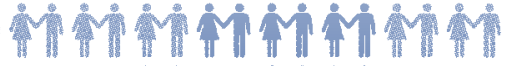

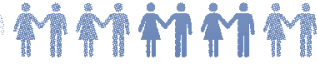

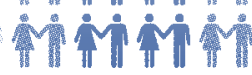

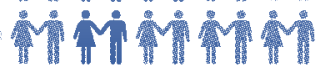

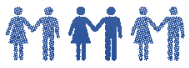

în

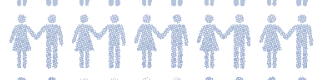

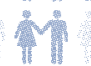

Min

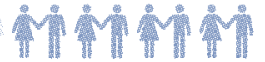

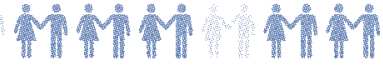

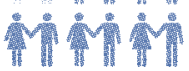

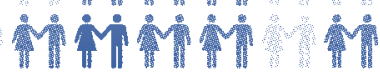

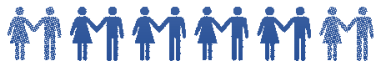
oh 


\section{Co-operative societies in society: classifications and incorporation}

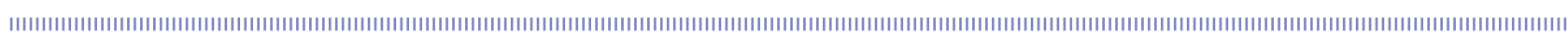

\section{Learning objectives}

This chapter explains the three principal ways of classifying co-operatives: the area-based method, the membership-based method, and the group-served method. It then discusses the legal structures and regulation within which co-operatives in Britain operate. By the end of this chapter you will be able to:

- identify the different types of co-operatives;

- assess the advantages and disadvantages of various methods of classification;

- recognise the legal structures that apply to co-operatives.

The key arguments that will be developed in this chapter are:

Co-operatives are classed in different ways: by area, by membership, and by group served.

Co-operatives are most commonly classed according to the type of group served.

The group-served method distinguishes between consumer co-operatives, producer co-operatives, worker co-operatives, and hybrid co-operatives.

There is a legal framework for establishing and running a co-operative.

\section{Area-based method of classification}

The area-based method of classification relates to the geographical bounds within which a service or product is provided. Examples appear in the table below.

Table 8-Area-based classification of co-operatives

\begin{tabular}{|l|l|l|l|}
\hline \multicolumn{4}{|c|}{ Area served } \\
\hline Local: & Regional: & National: & International \\
Drumchapel Credit & Heart of England - & The Co-operative & Mondragón \\
Union - serves a & is a consumer society & Group - is the & Corporation - \\
local community in & serving Leicestershire, & largest consumer & has plants in 18 \\
the north-west of & Warwickshire and the & co-operative in & countries outside \\
Glasgow. & West Midlands & the UK and has a & of Spain. \\
& of England. & wide portfolio of & \\
& & businesses. & \\
\hline
\end{tabular}




\section{Membership-based method of classification}

Co-operatives can also be classified in terms of their membership. Classifying co-operatives by type of membership refers to whether the members are individuals or other businesses/co-operatives.

Table 9-Membership-based classification of co-operatives

\begin{tabular}{|c|c|c|}
\hline \multicolumn{3}{|c|}{ Type of membership } \\
\hline $\begin{array}{l}\text { Primary co-operative } \\
\text { (centralised): } \\
\text { Provides direct services to } \\
\text { patron-users (i.e. members). } \\
\text { An example would be a local } \\
\text { co-operative that sells groceries } \\
\text { directly to its members. }\end{array}$ & $\begin{array}{l}\text { Secondary co-operative } \\
\text { (federated): } \\
\text { Membership of a secondary } \\
\text { co-operative consists of other } \\
\text { co-operatives. }\end{array}$ & $\begin{array}{l}\text { Mixed: } \\
\text { Some co-operatives can supply } \\
\text { services to individual members } \\
\text { as well as other co-operative } \\
\text { businesses. }\end{array}$ \\
\hline
\end{tabular}

An example of a 'primary co-operative' would be GreenCity Wholefoods, a worker co-operative based in Glasgow providing employment to its members.

An example of a 'secondary co-operative' is the Co-operative Retail Trading Group (CRTG), which acts as a central buying point for all co-operative retail societies in the UK.

An example of a 'mixed co-operative' would be The Co-operative Group, whose membership includes both individuals and other businesses.

\section{Group-served method of classification}

The 'group-served' method is the most widely-used method of classifying co-operatives. ${ }^{1}$ Within each of the group categories (producers, consumers, workers, and hybrid) there are co-operatives that focus on different areas of activity, such as marketing, housing, or insurance.

Table 10-Group-served classification of co-operatives

\begin{tabular}{|l|l|l|l|}
\hline \multicolumn{2}{|c|}{ Group served } \\
\hline Producers: & Consumers: & Workers: & Hybrid: \\
Marketing & Retail & Can be any form & Serves two or more \\
Production supply & Credit & of business once & different groups \\
Service & Housing & democratically \\
Credit & Health & controlled by its & \\
Mutual insurance & Insurance & employees & \\
Machinery ring & Community & & \\
\hline
\end{tabular}

Source: M. A. Abrahamsen, Cooperative Business Enterprise (New York: McGraw-Hill, 1976), pp. 44-5. 
Sometimes classifications of co-operatives forgo distinguishing between producers and workers and group them together under producers. There is, however, a sound argument for splitting producers and workers into separate classes. Producers (for example, farmers) tend to remain self-employed and autonomous. In contrast, workers are employed directly by the co-operative. This is an important distinction which explains why the two groups are usually split. Let us now consider each of these four group-served types with some case studies.

\section{Producer co-operatives}

Producer-owned businesses enable self-employed individuals and businesses to gain the strength in numbers they need to survive in the market. An example of a producer co-operative would be a group of farmers banding together to market their produce jointly.

\section{Case study 4.1 - Ocean Spray}

Ocean Spray is an agricultural co-operative owned by more than 600 cranberry growers in the northern USA and Canada along with over seventy Florida grapefruit growers. The co-operative was formed in 1930 by three cranberry growers who shared a common goal of expanding the market for their crops through innovative products. ${ }^{2}$ The growers are from diverse regions in North America including British Columbia, Oregon, Wisconsin, Massachusetts, New Jersey and Florida. Ocean Spray employs more than 2,000 people worldwide and in 2009 generated revenues of around $\$ 1.9 \mathrm{bn} .{ }^{3}$ It is run from a headquarters surrounded by cranberry bogs in LakevilleMiddleboro, Massachusetts.

Ocean Spray is a type of enterprise known as a marketing co-operative. This means that Ocean Spray's owners use the co-operative for joint marketing and production operations. Each farmer will supply their produce to Ocean Spray, which offers the highest price it can as well as guaranteeing to purchase all of its members' produce. ${ }^{4}$ Ocean Spray then markets and sells the farmers' inputs through a wide range of products, including juices, dried fruit and sauces. As owners of the business, the farmers also share in the surplus generated by Ocean Spray.

\section{Consumer co-operatives}

Consumer-owned businesses provide people with goods at the lowest possible price, with a guarantee of good value, and so make their income go further. An example of a consumer co-operative would be a retailer serving a local community with food and toiletries.

\section{Case study 4.2 - The Co-operative Group}

The Co-operative Group, headquartered in Manchester, England, is the UK's largest consumer co-operative. ${ }^{5}$ Operating across multiple industries and with revenues of $£ 13.7 \mathrm{bn}$ in 2010 , the group is one of the most successful retail co-operatives in the world. The group has operations 
in food (producing and selling), financial services, travel, pharmacy, funeral care, legal services, electrical goods, and motor vehicles. Outlined below are some of the business's key statistics, as of 2 July 2011:

\begin{tabular}{|lrlr|}
\hline Group revenue & $£ 13.7 \mathrm{bn}$ & No. of members & $5.8 \mathrm{~m} 6$ \\
Pre-tax profit & $£ 545.7 \mathrm{~m}$ & No. of outlets & $>5,000$ \\
Member dividends & $£ 150.2 \mathrm{~m}$ & No. of employees & 110,000 \\
\hline
\end{tabular}

Central to the success of The Co-operative Group is the collective ownership structure of the business, whereby only those who trade with the co-operative can be owners. And as owners, members are entitled to a share of the profits generated by the business based on their patronage.

\section{Worker co-operatives}

Worker-owned businesses provide people with an income, but are also a way of gaining control over the conditions under which they labour, providing what the International Labour Organisation calls 'decent work'.

\section{Case study 4.3 - Suma Wholefoods}

Triangle Wholefoods Collective Limited, trading as Suma Wholefoods, is the UK's largest worker co-operative. Based in Elland, near Halifax, the company has over 120 members and a turnover of $£ 25 \mathrm{~m}$. Not only do the worker members collectively own the company and have the right to participate in a share of the profits generated, they also act as the ultimate governing body in the business through a non-hierarchical management structure.

\section{Democratic governance}

The organisation has a two tier structure for governance, with the members electing a Management Committee at the Annual General Meeting (AGM). The Management Committee consists of six members, with at least two places reserved for women, to ensure the Committee is representative of the broader worker membership. Half the Committee is re-elected each year. The Chair is termed a 'functional' Chair - conducting the roles of a Chair, without having any decision-making powers on the Committee. In addition to the six members and the functional Chair, the Committee also has a Finance Officer, Personnel Officer and Operations Co-ordinator - all of whom hold advisory roles in a non-voting capacity on the Committee.

The Management Committee meets weekly, and has delegated decision-making powers that have been agreed internally, and which are not described in the governing document. The general meeting, involving all members, meets six times during the year and agrees strategies, business plans and major policy decisions. The Management Committee is then given delegated decisionmaking to implement the plans and make recommendations to the general membership for future direction. Beyond the general meetings and meetings of the Management Committee, there are also Functional Area Co-ordinator meetings. 
Functional Area Co-ordinators meet daily to discuss and agree issues in distinct operational areas of the organisation. Minutes are taken at these meetings and forwarded to the Management Committee, as part of the Operations Co-ordinator's report. These Functional Area Co-ordinator meetings ensure decisions are shared amongst as many worker members as possible, and provide another opportunity for decision-making involving worker members. The governance structure of the co-operative enables the full worker membership to have control and ownership of decisions of the co-operative.

The Management Committee has delegated powers within agreed limits, although it must report back to the general membership over variations to the business plan, finances or personnel issues. The co-operative states that the Management Committee is there to monitor progress, not to direct or enforce decisions.

Source: Co-operatives UK. Suma Wholefoods, case study no. 6. Manchester: Co-operatives UK, (n.d).

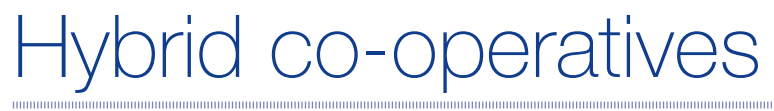

A hybrid co-operative (also known as a multi-stakeholder co-operative) is defined as a multimember class co-operative that has its own distinct rules regarding membership, governance and patronage. For example, Eroski supermarket, part of Mondragón Corporation, has both workers and consumers as its members. Hybrid co-operatives draw on the strengths and eliminate the weaknesses of different co-operative enterprises. For example, consumer co-operatives are scalable and highly adept at raising finance whereas worker co-operatives are committed to providing satisfying, rewarding employment for workers. There are three major factors in the structure of a hybrid co-operative:

Membership - What are the rules governing how different stakeholders become members e.g. should worker members contribute more capital and undergo a period of probation?

Governance - How should members be represented on the board, equally or by some other proportional mechanism?

Patronage $\quad-$ Should each membership class receive the same proportion of the surplus generated?

\section{Advantages:}

- More access to capital - wider membership base provides greater scope to raise finance.

- Facilitate participation - better decision-making by involving more stakeholders.

- Encourage loyalty.

\section{Challenges:}

- Increased complexity.

- Differences between member classes.

- Possible domination by one member class. 
Under UK legislation, co-operatives have a variety of options regarding the legal form for the enterprise. Three of the common legal forms are: ${ }^{7}$

- Industrial and Provident Society (IPS)

- Private company limited by guarantee

- Private company limited by shares

\section{Industrial and Provident Society ${ }^{8}$}

An IPS is an organisation conducting an industry, business or trade, either as a co-operative or for the benefit of the community, and is registered under the Industrial and Provident Societies Act 1965. Businesses that wish to set up as an industrial and provident society must register with the Financial Services Authority. Traditionally, co-operatives were set up under this Act because their unique ownership and governance structures were viewed as incompatible with registration under the Companies Act.

\section{Historical perspective}

The Industrial and Provident Societies Act 1852 provided a legal framework for co-operatives and mutual businesses in the UK. Prior to the 1852 Act, co-operatives were regulated by the Friendly Societies Acts of 1834 and 1846, which prevented co-operatives from selling to non-members. ${ }^{9}$ In 1862, the Act was amended to provide incorporation and limited liability for IPS enterprises, as well as allowing co-operatives to invest in other societies..$^{10}$ This Act preceded the incorporation of joint-stock (investor owned) companies by four years (the Companies Act 1856). The 1852 Act also made provision for certain features that were mandatory for societies to have in their articles of incorporation. For example, the Act stipulated that up to one third of the profits of the cooperative could be shared amongst the members, with the remainder used to build up the capital reserves of the business or for some other provident purpose.

\section{Co-operative Fact}

The term provident refers to the ability to foresee and make provision for the future, reflecting the importance co-operative businesses place on the accumulation of capital reserves through earning profit and member contributions (principle three).

\section{Requirements}

A society may register as an Industrial and Provident Society if it satisfies either of the two conditions found at Section 1 (2) of the Industrial and Provident Societies Act 1965: ${ }^{11}$

- The society is a bona fide co-operative; or

- In view of the fact that the business of the society is for the benefit of the community, there are special reasons why the society should be registered under the Industrial and Provident Societies Act 1965 rather than as a company under the Companies Act.

Every Industrial and Provident Society must have a minimum of three members (originally seven) at the time of registration, unless it is a secondary co-operative society (whose members consist of other co-operatives), in which case there must be at least two societies. 


\section{A Bona Fide Co-operative}

There is no legal or statutory definition of what a bona fide co-operative is; however, there is an agreed set of conditions that normally applies to co-operative status:

- The members of the co-operative must have a common economic, social or cultural need/ interest (note the similarity to the ICA definition of a co-operative).

- The purpose of the co-operative is to operate for the mutual benefit of its members.

- The co-operative is jointly-owned by the members and is democratically-controlled based on a system of one member/one vote, regardless of the amount of capital any one member contributes to the co-operative (democratic member control principle).

- There is a limited return (if any) on share and loan capital. This applies to the common capital funds the co-operative holds on behalf of its members (member economic participation principle).

- The members of the co-operative receive their share of the co-operative's profit in proportion to their participation in the business. In a retail society (consumer co-operative) this would reflect their purchase of goods and services from the co-operative; in a worker-owned society, it would be based on the amount of labour contributed to the business (which could be decided by hours worked, salary, seniority or years spent working in the business).

- There should be no discriminatory restrictions on membership (open and voluntary membership principle). ${ }^{12}$

These requirements were designed in such a way so as to reflect the ICA Statement on the Co-operative Identity.

\section{Regulation}

Industrial and Provident Societies are not subject to the same stringent regulations as other forms of enterprise. This is because 'the FSA does not have wide-ranging regulatory or prudential supervisory powers in relation to Industrial And Provident Societies'. ${ }^{13}$ In order to comply with FSA regulations, industrial and provident societies must:

- file an annual return, with accompanying accounts;

- pay an annual fee (calculated on a sliding scale based on the value of assets);

- notify the FSA of any significant changes (name, rules, registered office).

In return, the FSA has the authority to cancel the registration of the society if it breaches the 1965 Act and can also commission a review or inspection of a society's accounts if a specified proportion of the members of that society request. ${ }^{14}$

\section{Restrictions}

IPS legislation contains a number of outdated clauses that affect the manner in which co-operatives can raise capital. An individual is restricted from providing more than $£ 20,000$ to a co-operative; members who are co-operatives are not subject to a limit. ${ }^{15} \mathrm{~A}$ co-operative society that wishes to operate as a bank is restricted from issuing share capital that can be withdrawn as it would affect the business's ability to maintain adequate capital.

\section{Example of an IPS co-operative}

Lincolnshire Co-operative Limited, a consumer society based in the east of England, was established under the IPS Act in 1861 and is still trading. 


\section{Private Company Limited by Guarantee (CLG)}

Companies limited by guarantee do not have any share capital and members act as guarantors rather than shareholders - therefore they all have one vote. At the time of incorporation, members agree to guarantee a limited amount to creditors (usually $£ 1$ ) in the event of the business being wound up. This legal form is most common amongst charitable and voluntary organisations but has been utilised by co-operatives, particularly worker co-operatives, since it is thought to provide strong protection for the values and principles of the business.

\section{Example of a co-operative}

The Very People, a marketing co-operative based in Glasgow, Scotland, adopted the limited by guarantee model after advice and consultation from Co-operative Development Scotland (CDS). The six members do not hold any shares in the business and operate a one member/one vote governance system.

\section{Private Company Limited by Shares (CLS)}

Private companies limited by shares are prohibited from offering their shares to the general public but still retain the ability to raise capital from external sources. The liability associated with these shares only relates to the value of the capital originally invested (including any unpaid amount on the shares) in the event of the company winding up.

\section{Example of a co-operative}

Harness Care Co-operative, a health care practice operating in the Brent area of Greater London, registered as a company limited by shares in $2008 .^{16}$

Why choose a private company limited by shares rather than by guarantee? Companies limited by guarantee are unable to issue shares, restricting their ability to raise capital. While most cooperatives do not choose the limited by shares legal form, it is possible to operate a one member/ one vote governance system by issuing one voting share and additional non-voting shares in the co-operative. There is a danger however, that members will seek to maximise the value of the co-operative in order to realise the capital gains accrued by their non-voting shares.

\section{The role of articles of association}

Every business that becomes incorporated must have a set of guidelines detailing how the business is to be run. In a company, procedures relating to governance, issuing of shares, and winding up are examples of issues that are explicitly documented in the articles of association. In effect, they act as the constitution for the firm, determining what the purpose of the company is and how it will govern itself.

Co-operatives incorporated under the IPS Act must also create a set of 'rules' outlining their purpose and procedures. ${ }^{17}$ For example, The Co-operative Group's rules outline the procedures relating to the purpose of the society; the way it is to be governed; issues concerning membership; and the workings of the board of directors. ${ }^{18}$

\section{Analysis of corporate legal structures}

In order to provide a framework for understanding the co-operative legal identity, it is useful to compare the IPS form with other business legal identities. This allows us to note areas where the IPS co-operative identity compares either favourably or unfavourably with other legal forms. 
Table 11-Comparison of business structures

\begin{tabular}{|c|c|c|c|c|}
\hline & Sole trader & Partnership & Company & $\begin{array}{l}\text { Industrial \& } \\
\text { Provident Society }\end{array}$ \\
\hline 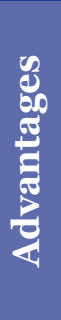 & $\begin{array}{l}\text { Easy and inexpensive } \\
\text { to organise } \\
\text { Owner has complete } \\
\text { control } \\
\text { Owner receives } \\
\text { all income }\end{array}$ & $\begin{array}{l}\text { Easy to organise } \\
\text { Partners share control } \\
\text { Partners receive } \\
\text { all income }\end{array}$ & $\begin{array}{l}\text { Owners have limited } \\
\text { liability } \\
\text { Large pool of investors } \\
\text { and easier to raise } \\
\text { capital } \\
\text { Business life is } \\
\text { perpetual }\end{array}$ & $\begin{array}{l}\text { Owners have limited } \\
\text { liability } \\
\text { Democratic governance } \\
\text { structure } \\
\text { Business life is } \\
\text { perpetual }\end{array}$ \\
\hline 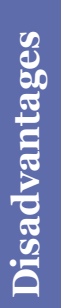 & $\begin{array}{l}\text { Owner has unlimited } \\
\text { liability } \\
\text { Owner is taxed on all } \\
\text { business profits } \\
\text { Not suitable for large or } \\
\text { complex businesses }\end{array}$ & $\begin{array}{l}\text { Some partners have } \\
\text { unlimited liability } \\
\text { Partners are taxed } \\
\text { on all business profits } \\
\text { Personality differences } \\
\text { may cause problems }\end{array}$ & $\begin{array}{l}\text { Double taxation } \\
\text { (corporate profits and } \\
\text { dividends) } \\
\text { Small investors have } \\
\text { little control in a large } \\
\text { plc }\end{array}$ & $\begin{array}{l}\text { Limited return on } \\
\text { capital } \\
\text { Difficult to raise external } \\
\text { capital in the form of } \\
\text { equity } \\
\text { Limits on the amount } \\
\text { members can invest }\end{array}$ \\
\hline
\end{tabular}

Source: Adapted from K. Zeuli and R. Cropp, Cooperatives: Principles and practices in the 21st century (Wisconsin: University of Wisconsin Center for Cooperatives, 2004), chapter 5.

\section{Factors influencing the choice of legal form}

A business must carefully assess its financial and administrative needs before choosing a legal structure. For example, a capital intensive company, such as a manufacturer of electronic components, will most likely choose a CLS structure to facilitate capital investment in the business. Co-operatives tend not to select this legal form as they must protect the interests of members over external investors. Ridley-Duff and Bull argue that 'the social identity of the owners (investors, consumers or employees) radically transforms the way the organisation is run, and the way the benefits of ownership and trading are distributed. ${ }^{19}$ For example, Infinity Foods Co-operative Ltd, a worker co-operative based in Brighton, England, registered as an IPS in 1979. A number of wholefood worker co-operatives emerged during this decade and they tended to share a close affinity with the ICA's values and principles. This trend has been superseded by the emergence of more service-oriented consortium co-operatives and these tend to select the CLG model (which only became available as an option for co-operatives in the 1980s) as they are more concerned with pooling their resources and tendering for larger contracts than the values and principles. An example of such a co-operative would be Bridges: The Actors' Agency based in Edinburgh, Scotland..$^{20}$ There are, of course, more practical factors that influence the selection of a legal identity. Smaller co-operatives will tend to adopt a form that is relatively inexpensive to register; co-operatives of all sizes will also take into account the future tax efficient reward options.

\section{Conclusion}

The choice of legal form is influenced not only by the financial and administrative needs of the business but by the social identity of the entrepreneur(s). Different legal structures reflect who has the right of power in organisations (members, shareholders or founders). It is vital that whoever holds power as a result of the legal structure actively participates in the governance of the organisation. Otherwise, the legal structure merely complies with existing legislation and does not promote or facilitate active owner participation. 


\section{Summary of learning}

This chapter has argued that:

- There are different ways of classifying co-operatives but the most common method is by group served.

- Co-operatives have a variety of legal forms under which to incorporate.

- There are numerous benefits and disadvantages to each legal form and a clear understanding of the co-operative's financial and administrative needs is required to select the appropriate structure.

- Different legal forms protect the interests of the holders of power in an organisation; a co-operative must ensure that the members of the business are recognised by the chosen legal form.

\section{Essay/discussion questions}

- What are the difficulties of classifying co-operatives?

- Identify the types of co-operatives operating in your community. How would you classify them?

- Considering the restrictions placed on a business if it registers as an Industrial and Provident Society, are co-operatives better served by other legal forms?

- What advantages would a co-operative derive from registering as a CLS or CLG?

\section{Useful resources}

Mutuals Register - https://mutuals.fsa.gov.uk/.

Companies House - http://www.companieshouse.gov.uk.

Co-operative and Community Benefit Societies and Credit Unions Act 2010 http://www.legislation.gov.uk/ukpga/2010/7/contents. 
1. J. Atherton, J. Birchall, E. Mayo, and G. Simon, Practical Tools for Defining Co-operatives (Manchester: Co-operatives UK, 2011), p. 9; J. Birchall, People-centred Businesses: Co-operatives, Mutuals and the Idea of Membership (London: Palgrave Macmillan, 2010).

2. Ocean Spray, 'Our Growers Cooperative’. http://www.oceanspray.co.uk/heritage/growers, accessed 14 June 2011.

3. 'Ocean Spray’s Creative Juices' Businessweek 15 May 2006. http://www.businessweek.com/magazine/content/06_20/b3984097. htm, accessed 14 June 2011.

4. Yahoo Finance. http://biz.yahoo.com/ic/40/40346.html, accessed 14 June 2011.

5. Co-operatives UK, The UK Co-operative Economy 2011: Britain's Return to Co-operation (Manchester: Co-operatives UK, 2011), p. 24.

6. Reports from 2011 place this figure closer to 6.5 million.

7. The sections that follow will mainly discuss the specific legal forms that co-operatives can adopt in the UK. There are other options though; for co-operatives operating in the European Union, there is the European Cooperative Society (SCE) legal form. This piece of legislation was created to give co-operatives who wish to operate across multiple European borders a common legal identity.

8. Readers should note that the IPS Act has been superseded by The Co-operative and Community Benefit Societies and Credit Unions Act 2010; though the Act has been passed, it is not yet in force (a Legislative Reform Order to implement Act was approved 8 Nov 2011 and will come into effect in January 2012). This new Act seeks to modernise IPS legislation in the areas of registration, member capital contributions and corporate governance. A pdf outlining the main features of the new act can be accessed on the VLE.

9. K. Zeuli and R. Cropp, Cooperatives: Principles and Practices in the 21st century (Wisconsin: University of Wisconsin Center for Cooperatives, 2004.), p. 9.

10. Zeuli and Cropp, Cooperatives: Principles and Practices in the 21st century, p. 9.

11. HM Revenue \& Customs, 'Industrial and Provident Society: Background'. http://www.hmrc.gov.uk/manuals/ctmanual/CTM40505. htm, accessed 2 April 2011.

12. Financial Services Authority, Annual Report of the Registry of Friendly Societies 2000-2001 (London: Registry of Friendly Societies, 2002).

13. Financial Services Authority, Annual Report of the Registry of Friendly Societies 2000-2001.

14. Industrial and Provident Societies Act 1965 ss47, 49.

15. The newly named Co-operative and Community Benefit Societies and Credit Unions Act 2010 will, with the Legislative Reform Order (LRO) of January 2012, abolish the limits on how much non-withdrawable (transferable) share capital a member can supply to a co-operative; the limits will still be in place for withdrawable share capital.

16. For a detailed case study on Harness Care Co-operative see http://www.uk.coop/case-study/harness-care-co-operative.

17. See R. Ridley-Duff, 'Cooperative Social Enterprises: Company Rules, Access to Finance and Management Practice' Social Enterprise Journal 5 (2009): 50-68, for a discussion on the importance of the company rules in co-operatives.

18. The rules can be accessed from The Co-operative Group's website: http://www.co-operative.coop.

19 R. Ridley-Duff and M. Bull, Understanding Social Enterprise: Theory \& Practice (London: Sage, 2011$)$, p. 138.

20. This is not to say that co-operatives that register as a CLG are opposed to or unaware of the values and principles; rather, our argument is that the ideologies and values of the founding members of a business influence the legal form that is adopted. 


\section{Democracy in \\ the workplace I: worker co-operatives}

'The form of association, however, which if mankind continue to improve, must be expected in the end to predominate, is not that which can exist between a capitalist as chief, and workpeople without a voice in the management, but the association of the labourers themselves on terms of equality, collectively owning the capital with which they carry on their operations, and working under managers elected and removable by themselves.'

John Stuart Mill

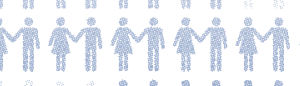

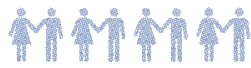

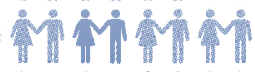

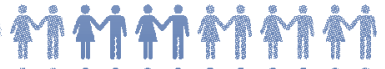

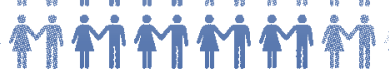

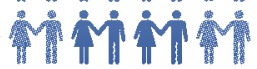

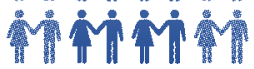

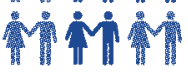

in

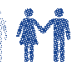

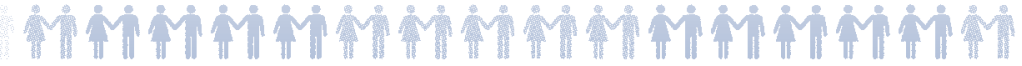

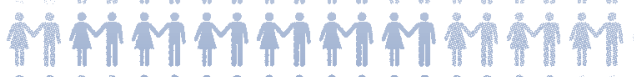

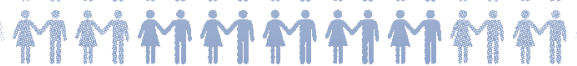

Mำ

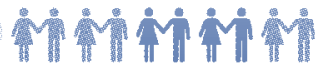

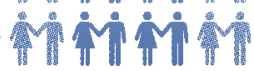

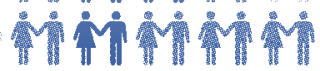

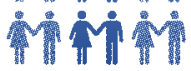

in

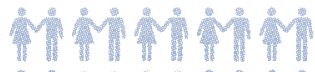

率

Min

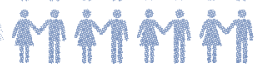

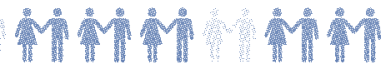

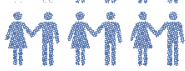

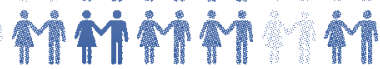

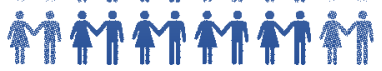

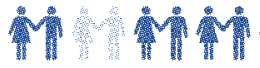




\section{Democracy in the workplace I: worker co-operatives}

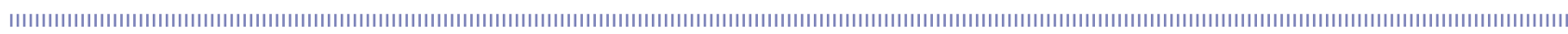

\section{Learning objectives}

This chapter begins a two-part analysis of employee-owned enterprises by looking at worker co-operatives. Considered to be one of the purest forms of employee ownership, the worker co-operative model places ownership, control, and beneficiary rights in the hands of workers. By the end of this chapter you will be able to:

- understand the economic reasoning behind the worker co-operative model;

- analyse key operational aspects of worker co-operatives;

- assess the ownership, governance and beneficiary arrangements of worker co-operatives in relation to other forms of co-operative.

\section{The key arguments that will be developed in this chapter are:}

Worker co-operatives must ensure they balance the needs of democracy and operations in order to create and sustain a viable co-operative enterprise.

Profit maximisation is a poor theory for the economic analysis of a worker co-operative.

The relationship between labour and capital in a worker co-operative is based on the primacy of labour, with capital as the subordinate ('labour hires capital').

There are specific management theories that are applicable to worker co-operatives but a new concept of the role of management is necessary for the implementation of these theories in practice.

Access to capital is crucial to the sustainability and growth of worker co-operatives; the importance of member contributions and retained earnings cannot be overstated in this regard.

\section{What is a worker co-operative?}

Ellerman defines a worker co-operative as 'a co-operative where the members are the people working in the company, and where patronage is based on their labour as measured by hours or pay. Thus a worker co-operative is a company where the membership rights, voting rights, and the profit rights are assigned to the people working in the company. ${ }^{11}$ We can further refine our concept of a worker co-operative by incorporating the internationally recognised co-operative principles into our definition, arriving at: 'worker co-operatives are businesses that are owned and democratically-controlled by their employee members using co-operative principles.' 


\section{Economic theory of worker co-operatives}

The economic theory of worker co-operatives replaces the traditional view of the firm as profit maximising with a different organisational purpose. For example, a worker co-operative may be established for the purpose of creating and sustaining jobs; to improve the quality of life of members; or to allow members to express democratic control over their working lives. Therefore, the underlying economic reasoning behind a worker co-operative is different from a conventional, profit maximising enterprise. ${ }^{3}$

Table 12 captures the relationship between labour and capital in a worker co-operative.

Table 12-Relationship between labour and capital in conventional and co-operative enterprises

Status of Factors of Production

Final Authority

\begin{tabular}{|l|l|l|}
\hline Conventional Enterprise & Capital & Labour \\
\hline Worker Co-operative Enterprise & Labour & Capital \\
\hline
\end{tabular}

In a worker co-operative labour hires capital, meaning that the ownership, control, and beneficiary rights accrue to labour as opposed to capital in a conventional firm. Capital is seen as an instrument for labour to direct; the worker co-operative operates for the benefit of labour, not capital.

In place of the profit maximising objective, Benjamin Ward (one of the first worker co-operative economic theorists) proposed a theory based on maximisation of a different factor: dividend (surplus per worker). Ward's formula, developed in 1958, is:

(pQ - C)/L where $\mathrm{p}=$ price of output, $\mathrm{Q}$ is output, $\mathrm{C}$ is costs, and $\mathrm{L}$ is number of workers. ${ }^{4}$

Ward's theory states that worker co-operatives will seek to maximise surplus per worker by adjusting L. He further argues that when surplus increases, L will decrease as the members will look to fire (or at least cease hiring) other members to increase their share of the surplus. Empirical studies have shown that this is not the case but Ward's formula is still a useful theory for understanding the economic reasoning behind a worker co-operative. ${ }^{5}$

Now we come to an important aspect in the development of the economic theory of worker co-operatives: how does a worker co-operative compare with conventional models of enterprise in terms of organisational success? Measuring the performance of a conventional company is relatively simple: how profitable is the business? Cornforth and others propose a different measure for worker co-operatives, one based on the concept of value-added. Value-added is the amount left over when costs are subtracted from revenue excluding the cost of labour. The authors argue that this measure is superior to profitability. ${ }^{6}$ For instance, paying members more in wages will result in less profit but that does not mean the business is performing poorly. 
Another measure of success uses a set of criteria based on internal and external objectives: ${ }^{7}$

- economic success;

- democratic aims;

- worker development;

- political/social objectives.

The criteria above demonstrate the need for a worker co-operative to separate and balance the democratic and economic aims of the business. The challenge this balancing act presents for a co-operative can be best summarised by discussing the concept of efficiency. In economic terms, efficiency means extracting the maximum value possible from the factors of production. Analysing worker co-operatives using this measure is not adequate because efficiency is defined purely in economic terms. For example, should worker co-operatives use environmentally damaging but cheaper raw materials to increase efficiency? Or reduce training budgets to boost profitability? Worker co-operatives must be economically viable but not necessarily economically superior to the investor-owned model of enterprise. The benefits and objectives of worker co-operatives cannot be reduced to a simple measure of profitability or efficiency.

\section{Ownership rights}

\section{Membership}

Worker co-operatives have traditionally been established and owned by two types of members. Each type generally correlates with the era in which the member became involved in the cooperative movement.

\section{Table 13-Specification of worker co-operative members}

\begin{tabular}{|l|l|}
\hline Ideological members (1970s) & Pragmatists (1980s) \\
\hline $\begin{array}{l}\text { Predominantly middle class } \\
\text { Well educated }\end{array}$ & $\begin{array}{l}\text { Predominantly working class } \\
\text { Rely on the worker co-operative for their } \\
\text { livelihood }\end{array}$ \\
$\begin{array}{l}\text { Able to experiment with various forms } \\
\text { of worker democracy }\end{array}$ & $\begin{array}{l}\text { The principles of co-operation are secondary } \\
\text { to the need to sustain the business }\end{array}$ \\
$\begin{array}{l}\text { Wholly committed to the principles } \\
\text { and spirit of co-operation }\end{array}$ & \\
\hline
\end{tabular}

While such a classification of members may seem overly simplistic, it does provide a framework for understanding the motivations and beliefs of members, factors that greatly influence the governance of a worker co-operative. Some members wholly buy into the co-operative principles and spirit while others may be only interested in exercising control over their work and participating in the fruits of their labour. What links both types of member is the democratic decision-making governance of the co-operative. ${ }^{8}$ 
In the UK, there are no specific laws or regulations relating to membership policies. ${ }^{9}$ Prospective members usually undertake a probationary period of six to twelve months before the members vote on whether to accept this person into membership of the co-operative. The ratio of members to non-members in a worker co-operative is a contentious issue; one could argue that a low ratio is a sign that the organisation is not properly worker-owned and controlled..$^{10}$

\section{Finance}

The traditional instruments used by firms to finance their operations are dividend-earning shares (equity) and interest-bearing debt. Firms require an optimal mix of equity and debt in order to attract the right amount and type of capital at the right time. In theory, the only form of financing not available to worker co-operatives is ordinary share capital. This is due to the fact that ordinary shares usually carry voting rights, contradicting the co-operative principle of one member/one vote. It is possible for co-operatives to offer non-voting ordinary shares (as well as preference shares) to generate investment in the business, but there are problems associated with this method of financing. ${ }^{11}$ Mellor, Hannah, and Stirling identify six sources of finance for worker co-operatives:

1. loans from members;

2. loans from other supportive individuals;

3. loans from banks;

4. grants and loans from local and national governments;

5. loans from within the co-operative movement;

6. loans from other mutual aid agencies such as trade unions or friendly societies. ${ }^{12}$

Mellor and others also argue that the unique financial challenges faced by worker co-operatives can result in 'a vicious circle where under capitalisation and lack of access to investment finance relegates them to a marginal existence'. ${ }^{13}$

Worker co-operatives are usually highly dependent on loan capital for their financing needs. This highlights the importance of a seventh source of capital for a worker co-operative: retained earnings (reserves). The members of a worker co-operative have a right to the surplus of the business. In theory, once interest and tax have been paid, the workers can decide to distribute the entire surplus amongst themselves. In practice however, this significantly reduces the capacity of the business to grow or deal with an unexpected cash flow emergency. Having a sizeable amount of retained earnings negates these two issues. Retained earnings can also act as collateral when seeking debt finance.

The most important source of finance for worker co-operatives is member contributions, particularly during the start-up process. Finance provided by members is critical in generating commitment and loyalty in the co-operative. ${ }^{14}$ There are risks, however, associated with raising significant amounts of finance through member equity or loans. First, there is the risk that resentment might arise between members who commit differing amounts of capital to the co-operative. Second, there is the possibility that members expect a return on their capital that detracts from the values and principles of the co-operative (principle three in particular). ${ }^{15}$ Third, if the amount of capital needed to become a member is excessively high, a situation might arise whereby workers are hired but cannot afford to become members; this leads to an increase in the amount of profit to be distributed to existing members but clearly violates principle one (open and voluntary membership). ${ }^{16}$ 
Thornley identified two significant problems worker co-operatives have in accessing capital:

- They do not have enough collateral in the form of member shares, loans and reserves to secure loans.

- Financial institutions are not adept at assessing the risk of lending to a collectively owned organisation. ${ }^{17}$

The second point is one of utmost importance for the employee ownership movement in the UK and is a priority for the major co-operative and employee ownership trade bodies (Co-operatives UK and the Employee Ownership Association).

\section{Control rights}

\section{Governance}

Final control of the firm in a worker co-operative rests with the workers. The two key areas where employees exercise control over the worker co-operative are:

- decision-making;

- profit distribution.

This does not mean that every employee is consulted and votes on each decision relating to the company. Rather, final authority on all important decisions, such as policy making, appointing management, and deciding on appropriate levels of pay lies with the workers. In effect, the employees fulfil the role of shareholders in a conventional firm, wielding ultimate control over the enterprise.

Figure 5-Typical governance structure of a worker co-operative

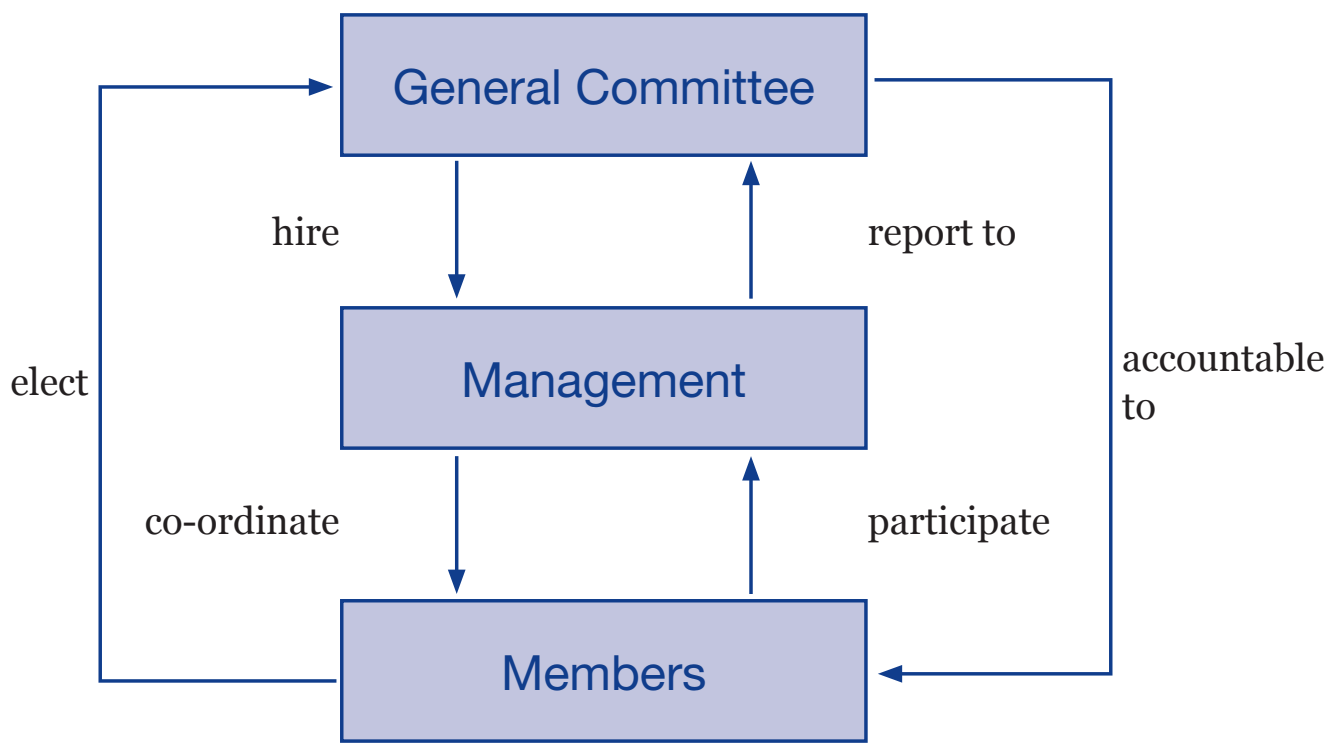


The AGM of a worker co-operative plays a critical role in the exercise of member control. ${ }^{18}$ Worker co-operatives tend to delegate decision-making responsibility to a General Committee once they reach a certain size and it becomes impractical to involve every member in policy and operations decision-making. The General Committee will then hire or elect a management team to oversee the day-to-day operations of the business. This separation of policy and operations is a key aspect in the smooth democratic functioning of a worker co-operative. The needs of members and the needs of the business must be clearly defined and a system put in place to ensure all needs are met.

\section{Case study 5.1 - \\ The Worker Co-operative Code of Governance}

Co-operatives UK, the representative body for consumer and worker co-operatives in the UK, produced a guide on governance for worker co-operatives. While accepting that the seven cooperative principles must be central to any code of governance, the report acknowledges that there are a number of guidelines specific to the worker co-operative model:

1. They are businesses that generate wealth to fulfil their principal objectives:

- To create and maintain sustainable jobs

- To improve the quality of life of the members

- To allow democratic self-management by members

- To allow all workers to work with dignity

- To promote community and local development

2. The membership of a worker co-operative is free and voluntary, but is governed by the number of sustainable jobs the business can support.

3. Whilst not all workers have to become members of the co-operative, the majority should be members. And, although some non-workers may be permitted to be members of the co-operative, in a worker co-operative the majority of the members ought to be workers.

4. Members of a co-operative have a different working relationship with the co-operative than either workers in a conventionally managed business or the self-employed contractor. But, note, this relationship is not recognised by UK employment legislation.

5. The internal regulation of a worker co-operative is determined by procedures that are agreed democratically by the members.

6. The worker co-operative must be autonomous and independent. A co-operative is obviously subject to UK law and regulation, but must not be subordinate to a third party in any aspect of its management, trade, employment, and ownership of the means of production. Further to that, a co-operative which is set up expressly to hive off an unprofitable branch of another business, or to provide labour for another business, is not a co-operative under the terms of this declaration. 


\section{Management}

The premise of a worker co-operative is that it gives control of the enterprise to the employees of the business. Workers usually exercise this control democratically at the AGM, but some choose to extend this level of control to the area of management. The traditional argument is that managers in a conventional company have a right to manage; this contrasts with worker co-operatives where the members have a responsibility to manage the enterprise, not a right. Depending on the size and complexity of the business, as well as the ideological orientation of the members, a worker co-operative will usually conform to one of the following managerial theories shown in Table $14 \cdot{ }^{19}$

Table 14-Management theories for worker co-operatives

\begin{tabular}{|l|l|}
\hline Collective management & Representative democracy \\
\hline No organisational hierarchy & Traditional organisational hierarchy \\
$\begin{array}{l}\text { The majority of business decisions are taken by } \\
\text { all the members }\end{array}$ & $\begin{array}{l}\text { Board of directors and management accountable } \\
\text { to the members }\end{array}$ \\
Consensus decision-making & Majority decision-making \\
Suitable for small, simple worker & $\begin{array}{l}\text { Suitable for more complex worker } \\
\text { co-operatives }\end{array}$ \\
Advantage - true worker democracy & Advantage - more efficient operations \\
Disadvantage - high transaction costs ${ }^{21}$ & Disadvantage - potential for management \\
& dominance over policy and operations \\
\hline
\end{tabular}

Management in a worker co-operative needs to be viewed as a function rather than a position. ${ }^{20}$ For example, Suma Wholefoods, a worker co-operative in West Yorkshire, assigns managerial responsibility for book-keeping and finance to several members who undertake this task along with their other responsibilities. Therefore, management ceases to be a power institution and simply a function necessary to ensure the enterprise operates efficiently.

Achieving a system of management similar to Suma requires the functions of management to be broken up into two areas:

Horizontal $\quad$ - vocational or technical management e.g. finance, supply chain, marketing.

Vertical $\quad$ - power based i.e. human resource management, hiring and firing, discipline.

It is the vertical aspect of management that causes difficulties amongst the members of a worker co-operative. ${ }^{21}$ These difficulties can be alleviated by delegating decision-making responsibility to several managers for horizontal areas of management, while involving all of the members for vertical issues such as hiring and firing members. The term 'co-ordinators' might be adopted for 'managers' within worker co-operatives. 
GreenCity Wholefoods is a non-exploitative workplace that takes into consideration the interests of workers, the community and the environment as a whole.

GreenCity Wholefoods Mission Statement

GreenCity Wholefoods was established on 6 June 1978 by four founding members along with three additional persons (at the time, IPS law required that seven people were needed to establish a worker co-operative). Like many young enterprises, the co-operative progressed slowly, experiencing difficulties along the way (mainly capital related), but eventually established itself as a profitable and ethical business. Today GreenCity generates over $£ 4 \mathrm{~m}$ per annum in revenue and has thirty-three members. From its humble beginnings operating out of a small flat in the West End of Glasgow to its current commercial success, the business has retained and improved an equitable and co-operative system of governance, management and membership development.

\section{Governance}

GreenCity is jointly-owned and democratically-controlled by its members and therefore operates a system of governance based on one member/one vote. Like most worker-co-operatives, GreenCity has a blended approach to decision-making; direct democracy (where every member is required to vote on a decision) is only called upon to deal with issues relating to policy or membership, while a system of delegated operational management (where the members elect a management team to make decisions on their behalf) is in place to deal with the majority of strategic and operational business issues. Any decision taken, whether at a monthly meeting or the AGM, needs an eighty per cent majority for it to be approved.

\section{Management}

GreenCity operates a flat management structure (the norm in most businesses is a hierarchical management structure), where individual members are elected to a management team to oversee the strategic operations of the business. The members serving on the management team are drawn from each of the functional areas, ensuring fair representation.

At an operational level, GreenCity is organised by functional area: accounts, sales, purchasing, manufacturing, warehousing and transport. Each of these departments operates largely autonomously (e.g. have their own meetings and targets) and decisions relating to day-to-day operations are entrusted to each department.

\section{Membership}

A committed and homogeneous membership is critical for the success of a worker co-operative. In GreenCity, every member is entitled to the same pay and benefits, a practice that is common in worker co-operatives with a flat management structure. The co-operative has a six month probationary period for new workers before offering them full membership, to ensure that the person is right for the business and vice versa. The Personnel and Training department plays an important role in the company; it encourages members to get involved in areas of the business outside of their specialism and facilitates this process.

The co-operative believes strongly in the importance of sharing information with every member. This not only ensures that members are kept up-to-date with developments in the business, but helps to generate high levels of member commitment. Some examples of this policy include ensuring every member is literate in financial matters (so they can participate effectively at the AGM), and disseminating company developments through a digital notice board to which every member can contribute. 
Pay

The issue of pay in an organisation is traditionally determined using a wage or salary model, which is linked to one or a number of factors such as hours worked, importance of role or seniority. In theoretical terms, members of a worker co-operative do not receive a wage or salary since they are the owners of the business and as such are entitled to the surplus generated by its activities. In practice, value added is calculated at the end of a trading or financial year and so it is unrealistic for members to receive the fruits of their labours only once a year. Therefore, some system of payment based on wage or salary must be implemented in the co-operative. How that is achieved depends on a variety of factors: ideological worker co-operatives tend to have equal pay while co-operatives that arose out of conversions or rescues are more likely to have traditional payment methods such as compensation based on role. The key point is that there are no hard and fast rules governing how a worker co-operative should compensate its members through wages or salaries; it is for the members to decide.

\section{Case study 5.3 - Edinburgh Bicycle Co-operative}

Edinburgh Bicycle Co-operative is a highly successful worker co-operative with outlets across the UK including Edinburgh, Aberdeen, Manchester, Newcastle, Sheffield and Leeds. When the business was founded in 1977, the members were committed to the ideological beliefs of worker co-operation and decided to express this solidarity by adopting an equal pay structure. As the co-operative grew, many of the members felt that this pay structure was unfair and a vote was taken to move to a system of pay based on a member's needs (for example, children to support). This structure lasted a few years before the members again felt that this system was unfair and so reverted back to equal pay. This was not to be the end of the evolution of Edinburgh Bicycle Co-operative's pay structure; it was changed another three times before the members eventually settled for pay based on an employee's position in the organisational hierarchy - but with limited pay differentials. A summary of Edinburgh Bicycle Co-operative's pay structure evolution is provided below:

- equal pay;

- to each according to their need;

- equal pay;

- pay based on seniority;

- pay reflecting position in hierarchical structure;

- pay reflecting position in hierarchical structure with explicitly limited differentials.

\section{Surplus}

Once the members have received their advance of the surplus in either wage or salary all that is left to do is allocate the remaining surplus amongst the members and the business. In theory, the members have a right to the entire surplus; this may be split for instance between wages and an end of year bonus. In practice, however, it is inadvisable to distribute the entire surplus to workers because it may expose the company to unforeseen risks and inhibit growth. ${ }^{23}$ Therefore, 
most worker co-operatives determine an appropriate allocation of the surplus between indivisible reserves (meaning no individual has any claim to this capital and remains the property of the business), the members, and, very often, a social or charitable cause. For example, a Mondragón co-operative might typically allocate forty-five per cent of surplus to members, forty five per cent to collective reserves, and ten per cent to a social/charitable fund. It is at the discretion of the worker co-operative how to allocate surplus and the method used will probably reflect the members' social, cultural and economic values and beliefs.

For the proportion of surplus allocated to members, a formula must be used to determine how much each individual member is to receive. This is usually done on a proportional basis, just like other co-operatives, but the criteria used may differ. For example, a worker may be entitled to a share of the surplus based on the number of hours that member worked in the year or the level of salary they received. Alternatively, some worker co-operatives distribute the surplus equally amongst the members.

\section{Net assets}

One of the other fundamental rights of ownership relates to the net assets of the firm (or the value of the business). The owners of a business are entitled to participate in the growth of the value of the business; the owners of a conventional company, for example, participate via the increase in the value of their shares. Also, if a company is wound up, the owners are entitled to the value of the net assets of the business (after any outstanding debt has been repaid). In the US, worker co-operatives have usually allocated this right to the membership share, along with voting and profit rights. ${ }^{24}$ The problem of bundling all the ownership rights up in one share occurs when the value of the business increases dramatically, with an equally dramatic rise in the value of the membership share. This poses two serious issues: ${ }^{26}$

- Members may seek to realise the increase in the value of the company by distributing the assets amongst themselves or by hiring non-members (thereby increasing their share of the profit).

- It becomes too expensive for a prospective member to join the co-operative as the value of the shares has increased exponentially. ${ }^{27}$

Most UK worker co-operatives have sought to eradicate this risk by designating the net assets of the company as being commonly owned; that means no individual worker has any right to the value of these assets. Ellerman proposes a solution to these problems by 'unbundling' the net asset rights from the membership and voting rights. Membership and voting rights are assigned to people based on their labour (personal rights) while the surplus and net asset rights become property rights; the most successful example would be the Mondragón system of internal capital accounts (see the extended case study at the end of the chapter). 


\section{EXERCISE - Conversion to a worker co-operative}

You have been given a brief by the Managing Director of a capital intensive manufacturing firm making advanced electronic goods (there are 175 employees) to look into the possibility of converting the company from a family-owned firm to a worker co-operative. Drawing on your reading, and making use of the Worker Co-operative Code of Governance, what arguments would you make for and against this course of action? What would your final recommendation be and why?

Note: the underlined terms are the variables in this exercise. It is possible to substitute these variables to produce a different exercise for students. For example, the firm in question could be a labour intensive media company with twenty-five employees or the firm could be publicly listed. Changing the variables this way could be used as the basis of a group discussion on the different recommendations of students.

Thanks are given to Professor Andrew Pendleton of the University of York for his permission to use this exercise in the text.

\section{Extended Case Study Mondragón Corporation}

'Our attempt at co-operative enterprise is nothing more than a kind of formal association, oriented toward solidarity, created by workers in an environment of liberty and justice.'

Don José María Arizmendiarrieta

\section{Historical development}

'In 1941, a young Basque priest, Father Jose Maria Arizmendiarrieta, came to Mondragón, a small working-class town in the Basque province of Guipuzcoa in Northern Spain. He began his teaching work in the apprentice school of the Union Cerrajera, the industrial company which dominated the town of Mondragón. This school however, was not large enough to provide adequate training to the local youth. Failing to enlarge the school, Father Arizmendi gathered the support of the townspeople and opened a technical training school in 1943 with twenty students. ${ }^{27}$

The first graduates of the technical college (Escuela Profesional) began their careers at Union Cerrajera but some had a falling out with management after they were refused the right to purchase shares in the company. Five of these graduates - Luis Usatorre, Jesús Larrañaga, Alfonso Gorroñogoitia, José Ormaechea and Javier Ortubay - encouraged by the continuing support and guidance of Father Arizmendi, decided to put his teachings into practice and in 1955 acquired a bankrupt factory in Vitoria, near Mondragón, and a licence to produce small paraffin heaters and stoves. ${ }^{28}$ The business was named ULGOR (after the founders' initials) and in 1956 developed a constitution that was to become the template for other worker co-operatives in the Basque country. 
ULGOR grew rapidly and employed 143 workers by the end of 1958 . The period of 1956-59 was characterised by the entrepreneurial drive of ULGOR's founders, resulting in the creation of a number of new co-operatives including Arrasate (the Basque name for Mondragón), Funcor (an iron smelting business), San Jose (which merged with other consumer co-operatives to form Eroski, now one of the largest retailers in Spain), Copreci and Ederlan. ${ }^{29}$

The movement grew rapidly. By 1982 there were over eighty-five industrial co-operatives as well as a host of agricultural, retail, housing and education co-operatives. One of Father Arizmendi's core beliefs regarding co-operativism lay in the strength of association. He believed that a solitary worker co-operative would be inherently weak and vulnerable to other forces outside of its control. Strength lay in federations of worker co-operatives, sharing resources and profits, as well as risk. Initially, worker co-operatives founded regional federations; the first federation was established in 1965 by ULGOR, Arrasate, Ederlan and Copreci. Known as ULARCO, its purpose was to provide shared marketing, product and sales resources, as well as having a common pool of capital. ${ }^{30}$ Various federations were established between then and 1987, when the first co-operative congress took place. The Mondragón Corporation (MC) was born.

\section{Individual co-operative structure}

Figure 6-Organisational structure of an individual Mondragón co-operative

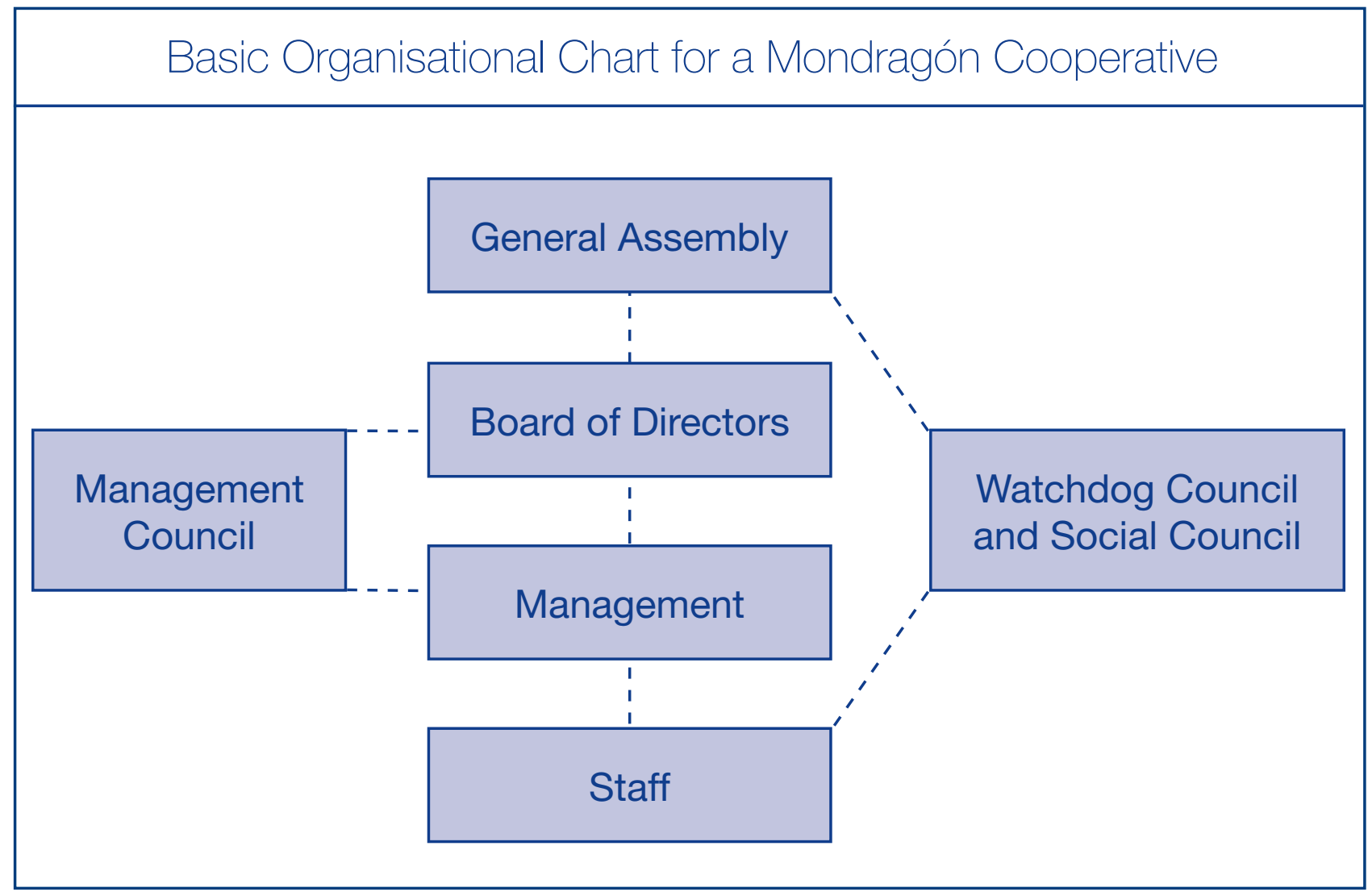

Source: D. P. Ellerman, The Mondragón Cooperative Movement. Harvard Business School Case No. 1-384-27o. (Boston: Harvard Business School, 1984).

The above diagram is a conceptual view of the governance structure of an individual Mondragón worker co-operative. The ultimate authority in the co-operative is the General Assembly (GA), the annual meeting of the members. The Assembly elects (on a one member/one vote basis) the board of directors or the Junta Rectora. The board of directors appoints the president (chief executive officer) and the management team. The management team then directs the staff (members) in the pursuit of the co-operative's objectives. There is a clear line of accountability to the members in the operations of the co-operative. 


\section{The role of the councils ${ }^{31}$}

\section{Management Council}

The Management Council acts as an advisory body to the board of directors. Its membership consists of the management team and the president of the co-operative.

\section{Social Council}

The Social Council is concerned with issues directly affecting members such as pay structures, health and safety, and conditions of employment. Members are directly elected to the council by dividing workers into sections (usually of fifteen to twenty people) and then voting for a section representative. The section representatives then form the Social Council which meets at least once every three months. While the council is mainly an advisory body, it does have some decisionmaking powers relating to pay scales, safety and social security.

\section{Audit Council}

Directly elected by the GA, the Audit Council performs an auditing role in the co-operative, for example by ensuring financial statements are accurate. The GA can request information from the management team which is then passed on to the Audit Council for verification.

The other important aspect of an individual Mondragón co-operative that deserves attention is its treatment of the growth in the value of the business. A co-operative allows each member to participate in this growth through an internal capital account. This account contains the member's capital contribution (membership fee) and every year interest is paid on this amount, assuming the business is profitable. The amount in this capital account is also increased using the surplus generated at the end of a trading year. Up to seventy per cent of the surplus generated is allocated to the members' capital accounts on a proportional basis. Of the remainder, a minimum of twenty per cent is allocated to the collective reserves of the business and ten per cent for social/ charitable causes.$^{32}$ There are rules however, governing access to the capital accounts. Members can only access the full amount in their capital accounts upon retirement. If a member resigns or is fired, they are only entitled to seventy per cent of the value of their capital account. ${ }^{33}$

In the next section we will encounter the Mondragón Principles of Co-operation, one of which is Wage Solidarity. This principle is of particular importance in individual co-operatives as it sets a wage differential limit between the highest earner in the company and the lowest. The ratio was originally 3:1 but has now risen to around 6:1 (though the scale can rise to 8 in exceptional circumstances), meaning the director or highest paid manager of a co-operative cannot earn more than six times the wage of the lowest paid worker. This principle has obvious implications for recruitment policies, making it more difficult to retain and attract senior management.

\section{Mondragón Corporation structure}

The first co-operative congress took place in 1987 and decided upon the basic principles of the co-operative experience and the group solidarity fund. ${ }^{35}$ The co-operative congress is equivalent to the General Assembly in an individual worker co-operative. The aim of the congress is to establish the strategic criteria by which the Corporation is to be administered, through the planning and co-ordination of its business units. It is made up of 650 members delegated by the various co-operatives.

The Standing Committee governs under a mandate of the co-operative congress. Its basic function is to promote and oversee the implementation of the policies and agreements adopted by the congress, while constantly monitoring the evolution of the group. The rest of the organisational structure can be seen in Figure 7. The group is divided into four key areas and these divisions are overseen by the General Council, which is responsible for the development and application of corporate strategies and objectives, as well as co-ordinating the policies of the different divisions and co-operatives. 


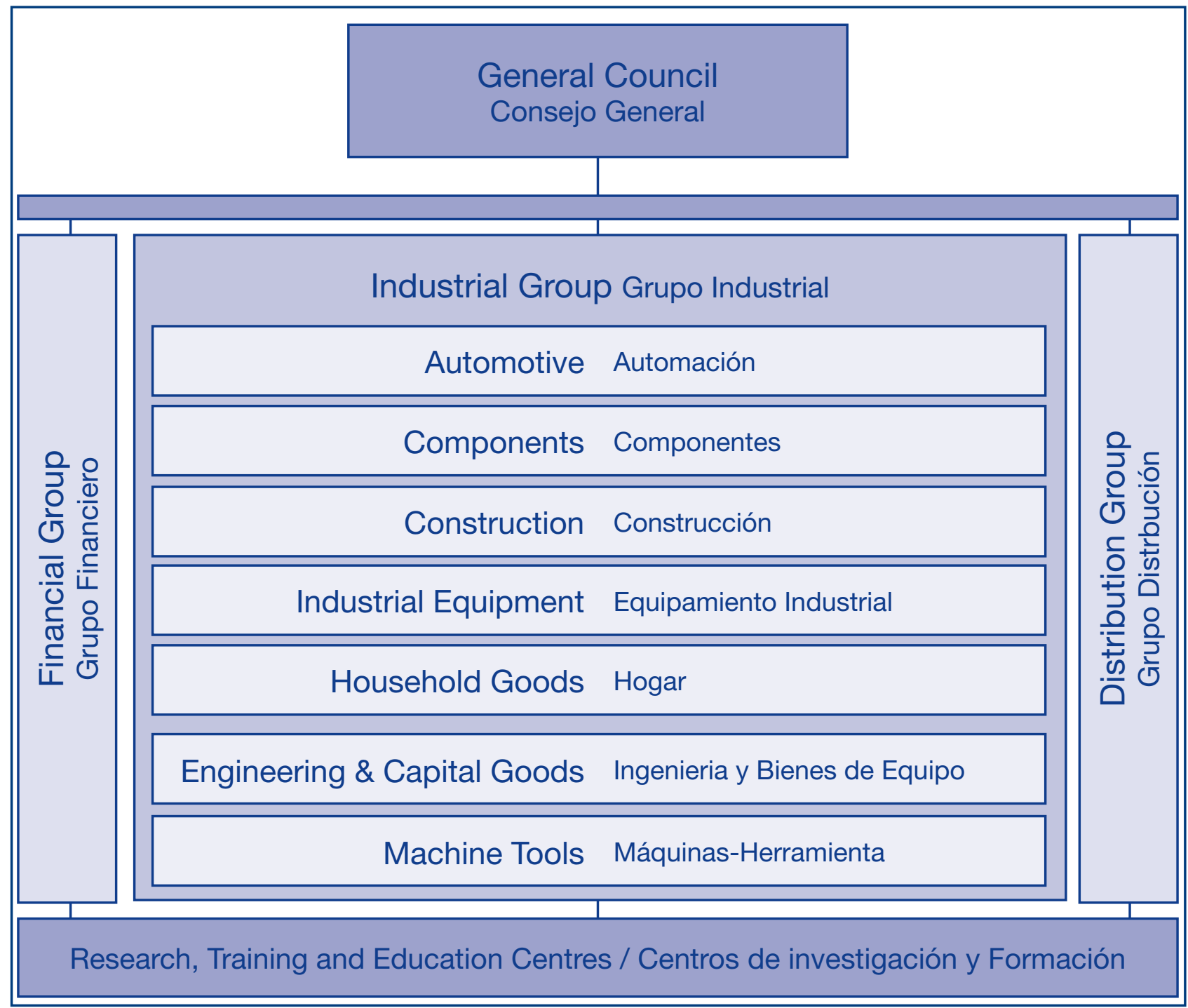

Source: J. R. Fernández, La Experiencia Cooperativa de Mondragón: 1956-20oo (Guipúzcoa: Mondragón Corporacion Cooperativa, 2001), p. 87. 


\begin{tabular}{|l|l|}
\hline Open Membership & $\begin{array}{l}\text { This principle declares that we are open to all men and women who } \\
\text { can demonstrate their professional capabilities for the jobs we are able } \\
\text { to create. }\end{array}$ \\
\hline $\begin{array}{l}\text { Democratic } \\
\text { Organisation }\end{array}$ & $\begin{array}{l}\text { Based on the equality of all our worker members, this principle } \\
\text { establishes 'one person one vote' as the basis of our democratic } \\
\text { organisation. }\end{array}$ \\
\hline Worker Sovereignty & $\begin{array}{l}\text { The main agent for transforming nature, society and people themselves, } \\
\text { and therefore deserving of the distribution of the wealth produced. }\end{array}$ \\
\hline $\begin{array}{l}\text { Instrumental and } \\
\text { of Capital }\end{array}$ & $\begin{array}{l}\text { Capital is an instrument subordinate to labour, and necessary } \\
\text { for business development. It is deserving of limited remuneration, } \\
\text { not directly linked to the results obtained. }\end{array}$ \\
\hline $\begin{array}{l}\text { Management } \\
\text { Participation }\end{array}$ & $\begin{array}{l}\text { This implies the progressive development of self-management with the } \\
\text { participation of members in business management. }\end{array}$ \\
\hline Wage Solidarity & $\begin{array}{l}\text { In accordance with the actual possibilities of each co-operative } \\
\text { enterprise and in solidarity with the rest of the Corporation and the } \\
\text { social environment. }\end{array}$ \\
\hline Interco-operation & $\begin{array}{l}\text { This involves searching for potential synergies derived from overall size: } \\
\text { the pooling of profits and the transfer of worker-members }\end{array}$ \\
\hline Transformation & $\begin{array}{l}\text { The creation of new co-operative jobs and support for } \\
\text { community development initiatives through the majority reinvestment } \\
\text { of profits. }\end{array}$ \\
\hline $\begin{array}{l}\text { Supportive of all those who work for social democracy, } \\
\text { sharing objectives of peace, justice and development. }\end{array}$ \\
\hline $\begin{array}{l}\text { The dedication of sufficient human and economic resources } \\
\text { for co-operative and professional training. }\end{array}$ \\
\hline Inion
\end{tabular}

\section{Superstructures}

Key to the development of Mondragón was the establishment of a support structure of organisations (many of them co-operatives themselves). Known as 'superstructures', these institutions include banks, insurance businesses, social security, research centres, schools, and many others. Scholars and practitioners agree that similar support structures are vital for other national co-operative movements as well, including the UK movement. Some of the most important Mondragón superstructures are outlined below.

\section{Caja Laboral Popular}

Between 1956 and 1959, the five founders of ULGOR established or assisted in the creation of several co-operatives, some of which were spun out from ULGOR. Father Arizmendi realised that the financial demands of these enterprises had outgrown conventional financial institutions and persuaded the co-operatives to establish a bank, the Caja Laboral Popular (CLP), in 1959. ${ }^{35}$ The CLP was to have a profound effect on the sustainability and growth of the Mondragón co-operatives. Not only did the bank act as a vital source of credit and other financial services, but it also assisted in the development of new co-operatives through its entrepreneurship and 
management department (known as the Empresarial Division)..$^{36}$ Between 1961 and 1970, over forty industrial worker co-operatives were established as result of the CLP. ${ }^{37}$ The bank financed the growth of the co-operatives through its deposits, the majority of which came from the savings of local Basque people. ${ }^{38}$ The CLP continues to play a vital role in the Mondragón Corporation and currently has total assets of over $€ 21 \mathrm{bn} .{ }^{39}$

\section{Lagun-Aro}

In 1958, Spanish government legislation decreed that members of worker co-operatives were ineligible to receive social security (as they were deemed to be self-employed). This change in circumstances led to the creation of an insurance, welfare, and pensions institution, Lagun-Aro, in $1967 .^{40}$ Today, Lagun-Aro's Endowment Fund stands at nearly $€ 4.5 \mathrm{bn}$ and supports thousands of members and their families. ${ }^{41}$

\section{Research, Training and Education Centres}

Some 3,438 students were enrolled in Mondragón University in 2010 and there are fourteen technology centres with an R\&D budget of $€ 144 \mathrm{~m}$. The role of research, particularly in the area of production technology, has played a vital part in the growth and evolution of the worker co-operatives, allowing them to weather economic recessions by innovating to create new product lines.

\section{Mondragón Corporation today ${ }^{42}$}

The Mondragón Corporation is the largest business group in the Basque country and the tenth largest in Spain, with turnover of $€ 14.75 \mathrm{bn}$. Perhaps the greatest success lies in its employment levels: from the initial ULGOR factory with a staff of twenty-five, the group now employs over 80,000 people worldwide. There are around 140 worker co-operatives that are members of the Corporation, and there are over 250 businesses in the group. The difference is explained by a large number of overseas factories which are not worker co-operatives. One of the current priorities is to introduce employee ownership in these subsidiaries over a period of time, with a view to eventually converting them into co-operative enterprises. One of the group's other pressing concerns is the education of the latest generation of Basque young people in the co-operative model of enterprise, a vital task in ensuring its sustainability in the region.

The Mondragón Corporation stands as the world's greatest example of industrial democracy and worker co-operativism. The group's success can be attributed to its culture of innovation and autonomy; largely cut off from the rest of the co-operative movement, the Mondragón co-operatives developed their own vision of co-operation, based on a unique set of principles and processes. 


\section{EXERCISE - Sharing wealth: lessons from Ohio}

In the video at the link below, a variety of community figures and leaders discuss a worker co-operative initiative in Cleveland, Ohio. Drawing on inspiration from the Mondragón system of worker co-operatives, the Evergreen Cooperatives aim to generate jobs and more importantly wealth for the local residents. Watch the video and consider the following questions:

1. How applicable is this model of worker ownership in areas with high levels of poverty?

2. What would be your recommendations if asked to assess how this model could grow and be replicated elsewhere?

Video: http://www.youtube.com/watch?v=Gt_ZHUDhKjs

\section{Summary of learning}

This chapter has argued that:

- Worker co-operatives are businesses that are owned and democratically-controlled by their employee members using co-operative principles.

- The theory of the conventional firm (profit maximisation) is ill-suited to worker co-operatives.

- While they are founded on the seven internationally recognised co-operative principles, worker co-operatives have a number of specific practices that form part of their code of governance.

- Worker co-operatives must balance the democratic and operational needs of the business to achieve their objectives.

- Management must be conceptualised in a different manner in worker co-operatives, based on functionality rather than power.

\section{Essay/discussion questions}

- 'Worker co-operatives are the purest form of employee ownership.' Drawing on material from this chapter and your own research, argue either for or against this statement.

- Why do you think there is so little worker ownership in the UK? What factors (economic, social or political) affect the development of the worker co-operative sector? 
Co-operative and Community Finance - http://www.coopfinance.coop/.

Campaign for Sustainable Employment - http://www.sustainableemployment.eu/?lang=en.

Co-operatives UK Worker Co-operatives group -

http://www.uk.coop/groups/worker-co-operatives.

Worker cooperative, Wikipedia article -

http://en.wikipedia.org/wiki/Worker_cooperative\#An_economic_model:_The_labor-managed_ firm.

The European Confederation of Workers' Cooperatives, Social Cooperatives and Social and Participative Enterprises - http://www.cecop.coop/?lang=en.

The International Organisation of Industrial, Artisanal and Service Producers' Cooperatives http://www.cicopa.coop/?lang=en.

US Federation of Worker Cooperatives - http://www.usworker.coop/education.

Mondragón Corporation - http://www.mondragon-corporation.com/ENG.aspx.

American Worker Co-operative - http://american.coop/.

International Labour Organisation - http://www.ilo.org/.

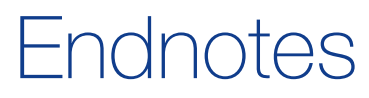

1. D. P. Ellerman, The Democratic Worker-Owned Firm (London: Unwin Hyman, 1990), p. 96.

2. Co-operatives UK, Worker Co-operative Code of Governance (Manchester: Co-operatives UK, 2009), p. 2.

3. J. P. Bonin, D. C. Jones, and L. Putterman, 'Theoretical and Empirical Studies of Producer Cooperatives: Will Ever the Twain Meet?' Journal of Economic Literature 31 (1993): 1290-1320. See p. 1294.

4. B. Ward, 'The Firm in Illyria: Market Syndicalism' American Economic Review 48 (1958): 566-89.

5. See D. C. Jones, 'British Producer Co-operatives' in K. Coates (ed.), The New Worker Co-operatives (Nottingham: Spokesman Books, 1976); B. Craig and J. Pencavel, 'The Behavior of Worker Cooperatives: The Plywood Companies of the Pacific Northwest' The American Economic Review 82 (1992): 1083-1105.

6. C. Cornforth, A. Thomas, R. G. Spear, and J. M. Lewis, Developing Successful Worker Co-operatives (London: Sage, 1988 ), p. 46.

7. M. Mellor, J. Hannah, and J. Stirling, Worker Cooperatives in Theory and Practice (Milton Keynes: Open University Press, 1988), p. 105.

8. Mellor, Hannah, and Stirling, Worker Cooperatives in Theory and Practice, p. 67.

9. Italian, French and Spanish worker co-operatives have rules relating to the number of non-members that can be employed, probationary periods for prospective members and other related issues.

10. Mellor, Hannah, and Stirling, Worker Cooperatives in Theory and Practice, p. 121.

11. One of the main problems with non-voting ordinary shares is the dividend that will be paid on these shares. Many co-operatives limit the amount of interest that can be paid on these shares and this makes them unattractive to investors seeking higher returns. On the other hand, if co-operatives were to offer to higher returns on these shares, the business would be at risk of being run for the benefit of capital rather than members. Preference shares are special types of share that do not carry any voting rights. After payment of interest on debt, preference share holders are the next in line to participate in the distribution of the surplus, ranking ahead of the members. Raising capital via preference shares is uncommon as the dividend on these shares is limited according to the co-operative principles, making them unattractive to investors. Some worker co-operatives have successfully used this method of financing: Equal Exchange in the USA offers $\$ 27.50$ preference shares with a target return of five per cent. 'Equal Exchange - fair trade, worker-ownership, and great returns for investors!' American Worker Cooperative 2 March 2011. http:// american.coop/content/equal-exchange-\%E2\%80\%93-fair-trade-worker-ownership-and-great-returns-investors, accessed 4 July 2011.

12. Mellor, Hannah, and Stirling, Worker Cooperatives in Theory and Practice, p. 73. 
13. Oakeshott mentions that significant member loans are mandatory in some worker co-operatives (for example, Mondragón) and provides a detailed account of how the Mondragón co-operatives established the Caja Laboral Popular to provide additional finance to new and existing co-operatives. R. Oakeshott, The Case for Workers' Co-ops (2nd edition) (Hampshire: Palgrave Macmillan, 1990), pp. 165-214.

16. It is not unreasonable to offer members a decent return on their capital, one that is commensurate with a basic savings account for example; the point is that this return is compensation rather than an investment opportunity.

17. For further detail on the risks associated with member finance, and the different sources of capital available to worker cooperatives, see Mellor, Hannah, and Stirling, Worker Cooperatives in Theory and Practice, p. 74.

18. J. Thornley, Workers' Co-operatives (London: Heinemann, 1981), p. 65.

19. Mellor and others stress the need for member training in the areas of participative decision-making (e.g. how to participate in a meeting) and conflict resolution to ensure the internal operations of the worker co-operative function smoothly and democratically. Mellor, Hannah, and Stirling, Worker Cooperatives in Theory and Practice, p. 115.

20. Cornforth, Thomas, Spear, and Lewis, Developing Successful Worker Co-operatives, pp. 134-5.

21. A transaction cost is an economic term for the myriad of interactions between the employees of a company to achieve an objective or perform a task. In the case of a worker co-operative practising collective management, high transaction costs refer to the time and money spent organising and co-ordinating meetings between all of the members to reach a decision.

22. C. Fanning and D. O'Mahony, 'Economic Theory of the Worker Co-operative: An Exposition' Economic and Industrial Democracy 4 (1983): 225-41. See p. 229.

23. Mellor, Hannah and Stirling, Worker Cooperatives in Theory and Practice, p. 121

24. There are a number of ways in which the surplus can be distributed to members. Two of the more common methods are in the form of cash and allocations to a capital account. It is less risky to distribute most the surplus to members in the form of allocations to a capital account as it creates a strong capital base for the co-operative, which can be drawn upon in times of financial distress.

25. Ellerman, The Democratic Worker-Owned Firm, p. 96. This means that every right is contingent on the individual remaining a member of the co-operative.

26. Ellerman, The Democratic Worker-Owned Firm, p. 97.

27. This situation arose in the Plywood worker co-operatives of the Pacific Northwest of the United States. Some co-operatives performed so well over a number of years that the value of a member's share had risen to tens of thousands of dollars, making it prohibitively expensive for new members to join. See case study 8.5 in chapter 8 for an account of one particular Plywood co-operative that experienced this increase in the value of membership shares.

28. D. P. Ellerman, The Mondragón Cooperative Movement. Harvard Business School Case No. 1-384-270 (Boston: Harvard Business School, 1984), p. 1.

29. R. Ridley-Duff and M. Bull, Mondragón Cooperative Corporation case study. Understanding Social Enterprise: Theory and Practice (London: Sage, 2011).

30. Ellerman, The Mondragón Cooperative Movement, pp. 1-2.

31. Ellerman, The Mondragón Cooperative Movement, p. 5.

32. Ellerman, The Mondragón Cooperative Movement, p. 7.

33. Ellerman, The Democratic Worker-Owned Firm, p. 101.

34. J. P. Bonin, D. C. Jones, L. Putterman, 'Theoretical and Empirical Studies of Producer Cooperatives: Will Ever the Twain Meet?' Journal of Economic Literature 31 (1993) 1290-1320. See p. 1298.

35. J. R. Fernández, La Experiencia Cooperativa de Mondragón: 1956-2000 (Guipúzcoa: Mondragón Corporacion Cooperativa, 2001), p. 57.

36. Fernández, La Experiencia Cooperativa de Mondragón: 1956-2000, p. 2. The bank itself is a co-operative: its membership consists of the Mondragón worker co-operatives who use its services as well as the employees of the bank. Representation on the board of the bank is shared proportionally between the two member groups, with eight of the board members elected by the worker co-operatives and four by the employees.

37. The Division drew on the experiences and knowledge of the founding members of ULGOR and institutionalised and generalised this knowledge in the department.

38. Fernández, La Experiencia Cooperativa de Mondragón: 1956-2000, p. 3.

39. Key to the CLP's popularity amongst Basque savers was a marketing campaign called something along the lines of 'Savings or Suitcase'. Basque residents were encouraged to save with the bank in order to support local economic development; the alternative was to pack your bags and leave the area as without your support there would be no jobs for locals.

40. CLP Audit Report, Consolidated annual accounts at 31 December 2010. https://www.cajalaboral.com/clweb/en/informes.aspx, accessed 28 June 2011.

41. Fernández, La Experiencia Cooperativa de Mondragón: 1956-2000, p. 15.

42. MC economic data 2010. http://www.mondragon-corporation.com/language/en-US/ENG/Economic-Data/Most-relevant-data. aspx, accessed 28 June 2011.

43. MONDRAGON Corporation, Video report of 2010 year. http://vimeo.com/24913713, accessed 28 June 2011. 


\section{Democracy in the workplace II: employee ownership}

'The employee is regarded by the employer merely in the light of his value as an operative. His productive capacity alone is taken into account.'

Leland Stanford

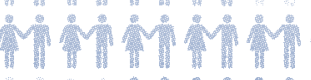

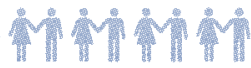

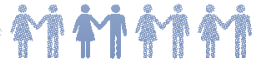

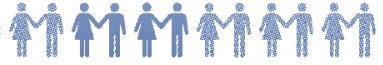

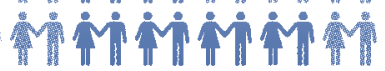

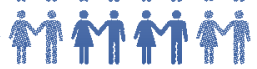

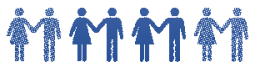

Mivip

in

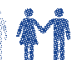

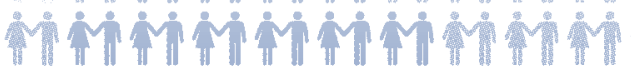

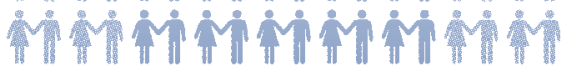

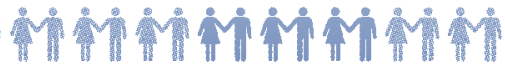

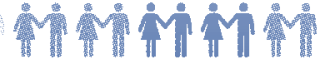

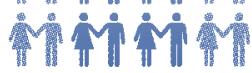

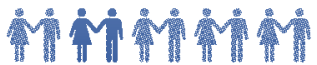

Mimin

în

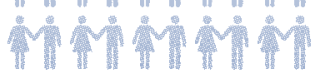

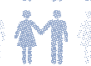

Min

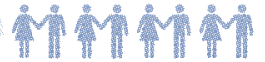

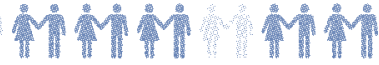
Mำin

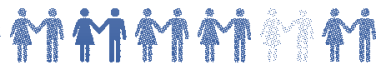

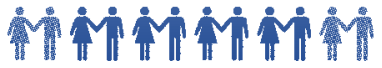
率 Min 


\section{Democracy in the workplace II: employee ownership}

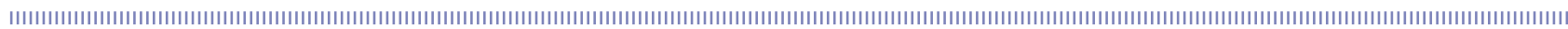

\section{Learning objectives}

This chapter shows that the spectrum of employee ownership is broad and there are key distinctions between various models within that spectrum. By the end of this chapter you will be able to:

- critically assess the main features of employee ownership;

- explain the rights of workers in an employee-owned firm;

- understand the nature and characteristics of the main forms of employee ownership.

The key arguments that will be developed in this chapter are:

Employee ownership encompasses a wide variety of organisational forms.

In an employee-owned firm, workers have the right to participate in ownership, governance and profit, as well as access to information and participation in management.

Employee-owned firms have developed a multitude of governance structures to facilitate employee participation in decision-making.

\section{What is employee ownership?}

'Companies where employees own a significant stake in the company they work for - sometimes termed 'co-owned' businesses - now account for combined annual turnover in excess of £25 billion, more than 2\% of GDP and growing.'1

\section{'Employee owned companies outperformed the FTSE All-Share in 2010 ... Employee owned companies' share prices were up 16.3\%, performing better than the FTSE All Share companies' share prices which went up by $11.3 \%$ over the year.'2}

\section{6m workers in the US participate in employee ownership plans worth around $\$ 901 \mathrm{bn} .^{3}$}

The term employee ownership (EO) has been used to encapsulate the entire spectrum of worker participation in the ownership of a firm. This is a diverse and complex phenomenon, so there are different understandings of what employee ownership means in practice. For example, employee ownership can refer to a minority shareholding by a minority of employees in a company (share plans such as the ones found in large publicly listed companies), or to one hundred per cent ownership and control of an organisation by all of its employees (worker co-operatives). 
The Employee Ownership Association (EOA), the representative body for employee-owned companies in the UK, defines employee ownership in the following terms:

Employee-owned businesses are companies where employees own a controlling stake in the business, i.e. more than fifty per cent. An employee-owned company may involve employees owning shares, but may instead or as well involve ownership via one or more trusts - for example, no employees own ordinary voting shares in the UK's largest employee-owned company: the John Lewis Partnership.

The EOA also supports another form of employee ownership known as 'co-ownership'. A 'coowned company' is a wider definition which includes employee-owned companies (as above) but also companies where employees own a substantial but minority stake in the business, say more than twenty-five per cent. Here again, employee ownership may be based on direct share ownership by staff, or indirect ownership via one or more trusts, or a combination of both shares and trust[s]. ${ }^{4}$

Another definition describes employee ownership as: 'an organisational arrangement in which a significant proportion (though not necessarily all) of the people who work in the firm (regardless of whether they are salaried or hourly workers) hold rights to organisational equity, information and influence. ${ }^{5}$ Even within this definition, there are still areas of the employee ownership spectrum that have not been addressed, such as minority share plans in large, public companies. ${ }^{6}$ Although the equity stake of employees in these companies is small (usually between one and five per cent), the value of the equity can be quite high as a result of the large market capitalisations of these companies. ${ }^{7}$

For the purposes of this study, the ideal form of employee ownership is any company that is majority-owned by its non-managerial employees, has some form of participation and democracy, and where employees exercise some form of control over the business.

\section{Features of employee ownership}

According to Rousseau and Shperling, employee ownership gives employees additional rights to those normally expected: a right to share in the company's profits, access to information on company finances and operations, and rights to participate in the management of the company. ${ }^{8}$ Allowing employees to participate in these rights influences their behaviour and attitudes, which then translates to better company performance and employee productivity. ${ }^{9}$ It is the extent to which employees participate in these ownership rights that distinguishes the different forms of employee ownership.

\section{Rationale}

The rationale for transferring the ownership of a business to its employees will have a crucial impact on the success of such an initiative. There are a variety of motivations and circumstances that lead to a company becoming employee-owned: aligning employee interests with those of the firm; co-operation and mutuality; creating and sustaining meaningful jobs; preventing the closure of a firm; and ideological beliefs of the current owner.

\section{Ownership}


Over and above the form of ownership (trust, direct shares, collective ownership), there are two key issues to address when analysing the ownership structure of an employee-owned firm:

1. How much of the company is owned by the employees?

2. How many employees participate in the ownership of the company?

Some employee-owned firms are one hundred per cent owned by their employees but only sixty per cent of employees are owners (as may happen with a direct share model), while others are sixty per cent owned by their employees and all of the employees are owners (usually found in an employee-owned company that uses a trust). Once a company has addressed the two questions above, there remain a number of other issues, such as the distribution of ownership amongst employees (equal or unequal shareholdings) and how employees participate in ownership (voluntary/compulsory and free shares/contributing capital).

\section{EXERCISE - Assessing an ownership structure}

Assume that you are a director of a company that is considering transferring ownership to its employees. You have been asked to assess the different ownership options available to the company and give a recommendation to the board. Specifically, the board want advice regarding how ownership should be distributed amongst employees and how the employees are to participate in ownership. Provide an assessment (strengths and weaknesses) of the different options that are available to the company.

\section{Governance}

Pendleton and others argue that in firms which are majority employee-owned, employees may have a strong sense of ownership and will expect a significant role in governance and management. ${ }^{10}$ According to our definition of employee ownership, employees should have ultimate authority in an organisation (fulfilling the role of shareholders in a conventional company). Unfortunately, employee participation in governance is not guaranteed in a firm that is employee-owned, as we shall see in examples below. Many companies design systems to exclude employees from governance and management or else only offer cursory opportunities to participate. ${ }^{11}$

Once an employee ownership structure is chosen, it is then at the discretion of the company to select an appropriate governance structure. There is an abundance of options available, including worker representation on the board, quality circles, participation in monthly management meetings, partnership councils, and outright decision-making and management control. 


\section{Beneficiary}

The level of participation in the surplus generated by the firm differs depending on the form of employee ownership. In a worker co-operative, employees are (in theory) entitled to the entire surplus generated by the business; in other firms employees receive a share of the profit based on salary; while in others again, the employees do not participate at all. Employee-owners are also entitled to benefit from the net assets of the business.

\section{Forms of employee ownership}

\section{Direct shares}

Direct share ownership of a business by its employees is facilitated by a specific legal structure: a private company limited by shares (CLS). For a company to be classed as employee-owned using this model, the majority of shares must be held by the majority of employees. The share capital model provides a number of benefits to employee-owners:

- direct participation in the growth of the value of the company;

- attractive model for outside investors (raising capital);

- flexible model that can incorporate a variety of ownership options (it can be used with a trust and gives ability to grant stock options).

\section{Distributing shares}

There are numerous options available for including employees in the ownership of company shares. The first issue to be decided is how many employees are to participate in share ownership. Ideally, every employee should be included through some sort of subscription or donation of shares (financed using company profits), with the option for individual employees to acquire more shares if possible. Unfortunately, some companies prevent certain employees from participating in share ownership by requiring them to purchase the shares directly, which involves a significant capital investment (something which is often beyond the means of lower paid workers). This leads to a situation where wealthy employees (often managers) acquire the majority of shares, creating an inequitable system of ownership and governance. It is generally accepted that when employees contribute or sacrifice capital to participate in share ownership, their levels of commitment and feelings of psychological ownership are increased. ${ }^{12}$ The task is to ensure that share offerings are affordable to the vast majority of employees. The company must also decide whether other stakeholders can own shares (since the strength of having a CLS legal form is the ability to attract external investment). Many companies include provisions in their articles of association to limit the amount of shares that can be held by non-employees.

\section{Transferring shares}

Most employee-owned companies will stipulate that a certain majority of shares must remain with employees and cannot be sold to external stakeholders. How then does the company allow employees to realise the value of their shares? One solution is to create an internal stock market so employees can cash in on their shares whilst preserving the employee ownership structure of the business. In the event of there not being enough buyers or sellers, the company can create a trust (covered in the next section) to act as a market regulator, purchasing shares and selling them as the situation dictates. Provisions must be in place to prevent individual employees acquiring a majority of shares through the internal stock market; some companies place a 
maximum shareholding of five per cent for an individual. On the other hand, some employeeowned companies forbid the transfer of shares between employees, mainly to prevent large inequalities amongst individual shareholdings. ${ }^{13}$

Another issue to consider is what happens when an employee leaves a business: should they be permitted to retain the shares or be obligated to sell them back to the company? Many private limited companies implement a policy where they have a right to buy back the shares when the employee leaves but in a manner that suits the company, either the full amount up front or over a period of months or years. ${ }^{14}$ The company may also arrange for another employee to purchase the shares if that is possible. Valuing these shares is done via a formula approved by Her Majesty's Revenue and Customs (HMRC). Usually a Price/Earnings ratio for a comparable listed company is used and then discounts are applied to reflect the fact that the company is private (if the company is public then the shares are valued according to the stock market on which they are listed).

\section{Sustaining employee ownership}

Firms with share capital that can be easily and freely traded (such as those that are listed on a stock exchange or market place) are not the best model for ensuring the longevity of employee ownership and control in a company:

- Employee shareholdings can become very valuable after a number of years in a successful business and this can prevent new employees from becoming shareholders. This leads to a situation where the company remains employee-owned and controlled but by a rapidly decreasing number of workers (the company is essentially degenerating into a capitalist company). ${ }^{15}$

- Cashing in on the value of the company has been a problem for employee-owned firms that do not make provisions for protecting the net assets from being distributed amongst employees. Employee-owners of a valuable company can liquidate the firm and distribute the value of the assets amongst themselves. ${ }^{16}$

The accumulation of collective reserves and an employee trust help to prevent either of the above scenarios from occurring by reducing the value of an employee's individual shareholding.

\section{Voting rights}

Traditionally, companies with share capital operate a governance system based on one share/one vote. It is possible, however to operate a more democratic system of governance (one person/one vote) by altering the articles of association. It is at the discretion of the company to decide the best system of governance to adopt.

\section{Case study 6.1-

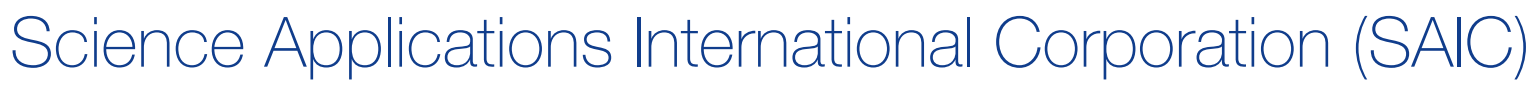

Founded by Bob Beyster, a physicist, in 1969, SAIC was for a time the largest employee-owned research and engineering firm in the US, with revenue reaching $\$ 8 \mathrm{bn}$ and 45,000 employeeowners by 2006. ${ }^{17}$ Key to the company's success throughout the years was its commitment to granting shares to as many employees as possible (known as broad-based employee ownership). For large parts of its existence, the company was entirely owned by its employees and over ninety per cent of employees participated in share ownership. ${ }^{18}$ The company used a combination of stock options and direct shareholding in its employee ownership structure ${ }^{19}$ The use of cash bonuses, shares and options (shares that can be bought in a number of years' time at current prices) were used as a means to engender commitment and promote a long-term outlook amongst employees. 
Of course, employees who wished to cash in on the value of their shares or purchase additional shares needed a medium to do so. To facilitate trading, the company established an internal share market (managed by a specially created subsidiary) that operated quarterly, offering employees the opportunity to trade. If no other employees wished to purchase available stock, the subsidiary would buy them. ${ }^{20}$

Of course, simply handing employees stock does not engender loyalty or a long-term outlook, features that were key to the success of the company. Employees were given ownership training by their peers to get across what it means to be an owner of a company - evidence of the importance of creating an ownership culture to complement financial participation.

The founder, Bob Beyster, was convinced that employee ownership drove the performance of the company, claiming that if he had not given away so much of the stock to employees, he "would own a much larger percentage of a far less valuable company. ${ }^{21}$

The story of SAIC also reveals an important point regarding leadership succession in employeeowned companies. A robust leadership succession strategy is crucial in employee-owned companies because you need someone who is passionate and committed to creating an ownership culture as well as an ownership structure. Unfortunately, upon the retirement of Bob Beyster in 2006, the board appointed someone without any enthusiasm for or knowledge of employee ownership and the company was subsequently floated on the stock exchange, where its share price has remained largely static to the present day (it doubled every five years while the company was employee-owned). ${ }^{22}$

\section{Employee Benefit Trust}

Employee Benefit Trusts (EBT) as they are now known are a popular means of transferring ownership of a business to employees using a special trust as the vehicle. A trust is 'a legal arrangement by which one person owns assets on behalf of somebody else. ${ }^{23}$ An EBT owns shares in a company for the benefit of current, and sometimes former, employees. The EBT that contains the shares is controlled by one or a number of trustees, usually appointed by the company. The trustees perform a number of important functions, such as deciding how to distribute the shares in the trust, how many each employee should receive, and when the distribution is to occur. Similarly, the trustees can decide to refrain from distributing shares, deciding that this approach is in the best interests of the employees of the company. ${ }^{24}$

The trustees are required to act in accordance with the trust deed, the document that establishes how the trustees are appointed, who the beneficiaries are, and what powers the trustees have. Most trust deeds require that the trustees hold all or most of the trust's shares in the company until the end of the trust period, usually eighty years. ${ }^{25}$ This prevents a situation arising whereby the trust distributes most of the shares in the company and the employees cease to be majority owners. At the end of the trust period, the trustees have a number of options regarding the shares held in the trust. They can choose to distribute the shares directly to the employees; establish another EBT and transfer the company's shares to it; or, in extreme cases, donate the value of the assets to a charitable organisation. 
An EBT can be utilised in a number of ways in a company:

Market maker in an internal market -

An EBT can be used as a mechanism to recycle shares in a private company. An EBT can facilitate the purchasing and selling of shares amongst employees, ensuring the shares remain in the company, thus preserving the ownership stake of the employees and providing them with an outlet to realise the value of their shares.

Warehouse for shares -

An EBT is often used to hold all or a majority of the shares in a company for the purpose of ensuring the company remains employee-owned. The shares are 'locked' in the trust for the duration of the trust period, often with restrictions on how and when the shares may be distributed to employees.

Providing an exit -

An EBT provides an opportunity for the founders or owners of a company to exit the business, ensuring the company is not bought by a competitor or floated on a stock market. The owner's shares can be purchased by the EBT using a loan secured on the future earnings of the company or financed directly by the company. ${ }^{26}$

Mechanism for employee share plans -

The EBT can be used as a vehicle for purchasing shares in a company for the purpose of an employee share plan such as a share incentive plan (SIP). This is the simplest use of an EBT and is commonly used by quoted companies with little interest in majority employee ownership or participation. ${ }^{27}$

It is important that a company assesses the following considerations before deciding on the use it is going to make of the EBT:

Is the trust going to hold all of the shares or just some?

An EBT that owns one hundred per cent of the shares protects the employee ownership structure of the company but does not cater for participation in decision-making or realisation of gains (i.e. a dividend or capital gain). It is possible for an EBT to be used in conjunction with an internal stock market to both protect the employee ownership structure of the company and offer individual employees a medium to realise financial gains.

How much control will the employees have in the company?

With an EBT, the employees do not usually have any direct power (in the form of voting at AGMs or sitting on the board of directors). Companies such as John Lewis and Scott Bader realise that employee financial participation without involvement in governance is not true employee ownership and have introduced democratic mechanisms to ensure employees can participate in the effective governance of the company (see case study 6.2).

How will the profit of the company be distributed?

As owners, employees are entitled to a share of the profit generated by the company. The amount they are entitled to is a matter for each individual company, but reinvestment in the business usually accounts for the majority of the profit, with a certain amount distributed to employees and the remainder to a charitable cause. ${ }^{28}$ 
The Partnership's ultimate purpose is the happiness of all its members, through their worthwhile and satisfying employment in a successful business.

The John Lewis Partnership is one of the UK's most recognisable and successful retailers with 35 John Lewis shops, 271 Waitrose supermarkets, and an online and catalogue business www.johnlewis.com. It is also one of the UK's largest and oldest employee-owned companies, combining a common ownership structure with a governance system based on democracy and a culture of participation. ${ }^{29}$

\section{Ownership}

Ownership of the John Lewis group of businesses resides in an employee trust, the John Lewis Partnership Trust, which is run for the benefit of the company's 76,500 employees, or 'partners'. In 1929, John Spedan Lewis, the son of the founder of the original John Lewis store in Oxford Street, London, transferred the majority of his shares to an employee benefit trust, 'to be owned in trust for the benefit of its members'. Spedan Lewis became the sole trustee of the business until 1950 when he transferred his remaining shares into the Trust and appointed three trustees; John Lewis had now become one hundred per cent employee-owned.

Employees do not hold the shares directly: one hundred per cent of the shares are held in the Trust which is governed by three trustees and the Chairman of John Lewis. The voting rights attached to the shares in the Trust are divided between the trustees (sixty per cent) and the Chairman (forty per cent). The trustees are elected annually by the Partnership Council, the highest, mainly elected, representative body of the company's partners. Therefore, employees do not hold direct voting rights in the company, resulting in the need to create democratic structures to enable the partners to exercise one of their fundamental rights of ownership. ${ }^{30}$

\section{Governance}

Governance in the partnership is exercised by three authorities: the Chairman, the Partnership Board (equivalent to a board of directors) and the Partnership Council. The Partnership Council is the mainly elected body of partners in the company, comprising partners elected from the branch councils and a number of individuals appointed by the Chairman. The Partnership Council has three key roles to play in the governance of the Partnership:

- to hold the Chairman to account and remove him if necessary;

- to influence policy by making recommendations to the Chairman and Partnership Board;

- to participate in making key governance decisions, including the election of non-executive directors to the Partnership Board.

The Chairman and Partnership Board operate similarly to a CEO and board of directors in an investor-owned company. The Partnership Board represents the highest form of employee participation in the governance of the business.

The rights and responsibilities of partners

Ownership of a company bestows a number of rights and responsibilities on the owners; the partners in John Lewis are no different. These rights and responsibilities are enshrined in the Partnership's constitution, and are outlined below. 
Rights:

- Profit: to share in the profit created by the business.

- Knowledge: to work in a transparent and open environment and to be made aware of the performance of the business.

- Power: to determine who runs the business and to hold management to account.

Responsibilities:

- To take responsibility for the performance of the business.

- To build relationships powered by the company's principles.

- Create real influence over their working lives.

\section{EXERCISE - Rights and responsibilities of ownership}

In the video at the link below, the ownership structure of John Lewis is outlined. Watch the video and consider the following questions:

1. As owners, what do you think are the responsibilities of the partners?

2. Why is a culture of democratic participation and engagement so important in an employee-owned company? Do you think it is enough for employees to simply own the business and just participate financially?

Video:http://www.mcmproductions-partnerconnect.com/johnlewis/index.asp?fn=JLP_ Partnership_Model__JLP_Partnership_Model

\section{Hybrid}

This form of employee ownership is based on some combination of direct shareholding and the use of a trust to hold shares collectively on behalf of the employees. This model reconciles the need for liquidity and stability in an employee-owned organisation. ${ }^{31}$ The stability of employee ownership in the company is ensured by placing the majority of shares (or fifty per cent) in an EBT, while also allowing employees to participate in the growth of the value of the company by owning shares directly. Some employee-owned companies create an internal stock market (similar to SAIC) to facilitate the trading of shares between employees and the company, while others sell shares to external investors as a means of raising capital. The hybrid model does require a robust governance structure to ensure that the employees and other stakeholders are fairly represented in the decision-making process. Considerations include how voting rights are distributed between the trust and direct shareholders, and whether employees 'vote twice' through their own shares and those of the trust. 
The founders of Loch Fyne Oysters seem on the face of it an unlikely pair: Johnny Noble, a wine merchant and owner of the Ardkinglas estate on the shores of the loch, and Andy Lane, a marine biologist and a passionate environmentalist. The two men met in a pub in the local village near Loch Fyne and it was there that they came up with the concept of Loch Fyne Oysters. They began farming oysters in 1979 and painstakingly built up the business. In the early 2000s, the business was generating turnover in the millions and employed over one hundred people. Both founders had begun discussing succession strategies and were interested in selling the company to the employees as one of several possible options. However, they had some reservations about this option, namely the costs that employees would have to bear if they were to purchase the company themselves (the eventual sale price equated to $£ 32,400$ per employee), and they were also concerned about realising the value of their efforts in building the business from scratch. ${ }^{32}$

A solution was found where the company could be sold to the employees for a fair price. Sadly, this solution was found only after the death of Johnny Noble (it was this event that forced Andy Lane to implement a succession strategy). The company was sold to the employees using an EBT; the trust borrowed $£_{3.5 \mathrm{~m}}$ (£1.5m from the bank and £2m from Baxi Partnership). Fifty per cent of the shares were then deposited in the trust while the other fifty per cent were distributed amongst the employees. It was a fundamental tenet of the share distribution that every employee was to participate in the ownership of shares (this was funded using a portion of the company's profit). ${ }^{34}$

This combination of using a trust and individual shareholdings has a number of advantages that have benefited the company. First, the company is likely to remain employee-owned in perpetuity since fifty per cent of the shares are locked into the trust, with no provision for them to be distributed amongst employees. Second, the trust enabled the employees to purchase the company without having to supply any of their own capital (something they never would have been able to afford). Third, the distribution of shares to employees tends to unlock a deeper sense of ownership amongst them as there are tangible benefits associated with holding shares directly. Finally, every employee in the company was able to participate in the ownership of the shares, as a portion of annual profits was used to purchase the shares and then distribute them to employees.

\section{ESOPs}

An Employee Stock Ownership Plan or ESOP is a type of employee benefit plan that uses a trust to accumulate and then distribute shares to employees. Originating in the US, but used in the UK as well, it bears many similarities to a profit sharing plan. The first employee ownership structure that would eventually become the ESOP was established in 1953 at Peninsula Newspapers Incorporated in the US by Louis Kelso, who with the help of Russell Long, a Louisiana senator, convinced the United States Congress to pass legislation governing the creation of ESOPs. ${ }^{35}$ ESOPs were primarily conceived as retirement savings plans for workers, with the threefold purpose of widening share ownership, facilitating capital formation, and improving company performance. ${ }^{36}$ Our discussion of the ESOP model of employee ownership will focus on the American experience. ${ }^{37}$ There are over 10,500 plans in the US covering more than thirteen million employees. 


\section{How do ESOPs work?}

The first step is for the company to establish a trust; this acts as a vehicle for the transfer of shares between the owners and employees. The trust then accumulates the shares of the owner in one of three ways:

- the company makes a contribution out of pre-tax profits to the trust, which then uses the funds to purchase the owner's shares;

- the company issues new shares into the trust;

- the trust secures a loan from a bank or financial service provider and uses it to purchase the shares from the owner. The loan is then repaid using pre-tax profits. This is known as a leveraged ESOP. ${ }^{38}$

The next stage involves the transfer of company shares to individual employees. The shares that reside in the trust are divided up and allocated into individual employee accounts. The formula used to decide how many shares each employee receives is at the discretion of the company. Some companies allocate shares equally amongst employees, some base it on hours worked, but the most common formula is based on an employee's salary. ${ }^{39}$

When can the employee access the shares?

North American legislation mandates that an ESOP must distribute shares to an employee within seven years of the employee joining the ESOP. Typically, a company will require an employee to be part of the scheme for five years before being eligible to receive their full allocation of shares. Companies usually adopt a process called 'vesting' to determine how many shares an employee is entitled to after a number of years. ${ }^{40}$

Table 16-Sample ESOP vesting process

\begin{tabular}{|l|c|}
\hline No. of years in the ESOP & \% vested \\
\hline 1 year & 20 \\
\hline 2 years & 40 \\
\hline 3 years & 60 \\
\hline 4 years & 80 \\
\hline 5 years or retires, dies or is disabled & 100 \\
\hline
\end{tabular}

An employee has one of two options when they receive their shares, depending on the type of company they work for:

- in a public company, the employee receives their shares and can sell them on the stock market;

- in a private organisation, the company is legally required (under US legislation) to purchase the employee's shares.

Voting rights

Despite their effectiveness in spreading wealth and capital more broadly in companies, ESOPs are not automatically a successful mechanism for transferring control to employees. Legislation allows companies to place voting rights with the trustees of the ESOP and employees only receive voting rights for supermajority issues, such as decisions relating to mergers, acquisitions or a sale. ${ }^{41}$ Employees typically have no input to decision-making about the appointment of directors and play only a marginal role in governance issues. That is not to say 
that companies do not offer some opportunities for employees to participate in decision-making, but the extent of input is at the discretion of the directors of the business.

Uses of ESOPs:

- to buy shares from a departing owner;

- to borrow money more tax efficiently;

- to create additional employee benefit.

\section{Rationale for ESOPs}

Many ESOPs are established for tax purposes; ESOP legislation provides generous tax incentives for businesses wishing to establish a plan:

- contributions of shares to the ESOP are tax-deductible;

- cash contributions to the ESOP are tax-deductible;

- contributions used to pay off the loan are tax-deductible. ${ }^{42}$

Issues to note

ESOPs are not automatically an effective means of involving employees in the governance of an organisation. There are also concerns that the minority ESOP form of employee ownership is not as significant to employees as holding shares directly. This can be attributed to the fact that employees do not contribute any personal wealth to the accumulation of company shares in an ESOP. An ESOP plan can be expensive from the employer's perspective; most plans typically cost between $\$ 30,000$ and $\$ 50,000$ to establish and accrue annual administration costs. Coupled with the legal requirement to repurchase shares when an employee decides to sell them, organisations under financial pressure are not prime candidates for an ESOP.

\section{Case study 6.3 - Allied Plywood}

Allied Plywood is a wholesaler and manufacturer of plywood and related building materials. Established in 1951 by Ed and Phyllis Sanders, the company is now headquartered in Virginia and operates across multiple states in the south east of America. It was one of the first companies to establish an ESOP and has managed to combine one hundred per cent employee ownership with a unique financial and governance participation structure.

\section{ESOP}

The first ESOP was established in 1977 as a means for the owners to retire. Acknowledging that the employees had played a significant role in the development of the business, the owners felt strongly that the employees should be given the option to purchase the company. By 1981, the ESOP held almost fifty per cent of the company's shares. This process did not involve the employees providing any of the funding needed to purchase the shares; a portion of the company's pre-tax profits was placed in the ESOP annually and used to purchase the shares from the original owners (known as an unleveraged ESOP). In 1982, the ESOP trustees took out a bank loan and purchased the remaining shares from the owners, meaning Allied Plywood had now become one hundred per cent employee-owned.

From 1981 onwards, the company's performance improved dramatically. Sales increased ten times while the number of employees increased seven fold. Even in 1990, a year of severe recession in the housing industry, productivity was over seventeen per cent higher than before the ESOP. Once the company repaid the loan it took out to enable the ESOP to purchase the shares in 1985, it issued 
new shares to the ESOP to enable current and future employees to participate in the ownership of the company. The net value of the equity in the company increased from $\$ 1.3 \mathrm{~m}$ in 1981 to $\$ 7.4 \mathrm{~m}$ in 1995 and the benefits to employees are substantial; all employees who have been on the Allied payroll since the ESOP was installed have accumulated accounts close to or exceeding $\$ 100,000$.

\section{A note on vesting}

Employees become eligible for shares in the ESOP from the day they are hired. Most ESOP companies have a probationary period of one year before employees are allowed to participate in the scheme. Employees are not entitled to the full value of their shares immediately, however; the process of vesting occurs over a number of years.

ESOP accounts of those who quit or are fired before three years of service are zero per cent vested, meaning that when they leave, they forfeit all their accumulated ESOP benefits. Upon completion of three years of service, vesting begins at twenty per cent, with twenty per cent added each following year. In year seven, an employee's account becomes one hundred per cent vested and is no longer subject to any forfeiture. Those who reach retirement age, become disabled, or die become one hundred per cent vested automatically.

\section{Combining financial reward with participation in governance}

Since the 1960 s, the company has operated a profit-related pay system whereby employees are paid less than the market rate (by around twenty per cent) but are entitled to an equal share of thirty per cent of operating profit, paid monthly in arrears. This significant financial participation is coupled with a practice of sharing company performance information. There is also an annual cash profit distribution based on a weighted formula according to the individual performance of the employee (for example, number of days worked, a peer review, or importance of the role).

There is something reminiscent of a worker co-operative about Allied Plywood's profit-related pay system. The employees are motivated by individual interest (annual bonus based on performance) as well as a mutual interest in ensuring that the company is profitable long-term (boosting their ESOP accounts and the ability of future employees to participate in the ESOP).

The company has five board members who govern the business and also act as the trustees of the ESOP. Two of the members are elected (on a one share/one vote system) by management representatives and two from worker representatives. The fifth member is an independent candidate chosen by both groups. The ESOP facilitates the sharing of risk and reward amongst the employees of the company, creating an ownership structure that allows employees to share in the rights and responsibilities of ownership.

Source: R. Oakeshott, Jobs \& Fairness: The Logic and Experience of Employee Ownership (Norwich: Michael Russell Ltd, 200o).

\section{Summary of employee ownership forms}

Readers should note that we have only covered some of the main forms of employee ownership; as with the co-operative model of enterprise, employee-owned firms can take a variety of forms and can differ in terms of their ownership, governance and beneficiary structures. The material covered in this chapter, as well as the information presented in the Table 17, represents a stylised view of employee ownership and readers are encouraged to bear this in mind as they reflect on this topic. 
Table 17-The three forms of employee ownership

\begin{tabular}{|l|c|c|c|}
\cline { 2 - 4 } \multicolumn{1}{c|}{} & $\begin{array}{c}\text { Minority share } \\
\text { plans }\end{array}$ & $\begin{array}{c}\text { Workers' } \\
\text { co-operatives } \\
\text { Amount of } \\
\text { equity held by } \\
\text { employees }\end{array}$ & $\begin{array}{c}\text { Majority employee } \\
\text { ownership (direct, trusts } \\
\text { and ESOPs) }\end{array}$ \\
\hline Ownership & $\begin{array}{c}\text { Minority }+ \\
\text { unequal }\end{array}$ & Majority + equal & Majority + equal/unequal \\
\hline Governance & $\begin{array}{c}\text { One share/ } \\
\text { one vote }\end{array}$ & One member/ \\
one vote & Varies 43 \\
\hline Rationale & $\begin{array}{c}\text { Align employee } \\
\text { interests with } \\
\text { the firm }\end{array}$ & $\begin{array}{c}\text { Co-operation and } \\
\text { mutuality }\end{array}$ & $\begin{array}{l}\text { Business succession } \\
\text { Protect jobs } \\
\text { To turn around a failing } \\
\text { business } \\
\text { Industrial democracy reasons } \\
\text { (shared capitalism) }\end{array}$ \\
\hline
\end{tabular}

Source: Adapted from Andrew Pendleton, The three forms of worker ownership: summary, Introduction to employee ownership.

\section{EXERCISE - Analysing employee-owned companies ${ }^{45}$}

Choose an employee-owned company to research. Use sources such as the company's website and any other publications or web-based resources you can find. Drawing on your research, address the following questions:

1. What proportion of the company is owned by the employees?

2. How is ownership distributed amongst the employees?

3. What is the nature of governance at this company?

4. How and why did the company become employee-owned?

Source: Employee Ownership and Governance module, University of York 


\section{Summary of learning}

This chapter has argued that:

- Employee ownership takes a variety of forms. There are differences, for example, between the EBT model in the UK and the ESOP model in the US, and between minority and majority ESOPs.

- In an employee-owned firm, workers have the right to participate in ownership, governance and profit, as well as access to information and participation in management.

- The selection of an appropriate governance structure is a crucial aspect of employee ownership.

- The extent to which employees participate in the rights of ownership differs for each form of employee ownership.

\section{Essay/discussion questions}

- Of the models of employee ownership analysed in this chapter, which one do you think best represents the ideal form of employee ownership? Is there an ideal form of employee ownership?

- Do you think that one model is more stable (in terms of organisational sustainability and in terms of preserving employee ownership) than the others?

- Is 1980 s style employee ownership (means of distributing wealth more widely and sustaining employment) simply an acceptable face of capitalism or a genuine alternative economic paradigm?

\section{Useful resources}

Employee Ownership Association - http://www.employeeownership.co.uk/home/.

The Ohio Employee Ownership Center - http://www.oeockent.org/.

John Lewis Partnership -

http://www.johnlewispartnership.co.uk/media/webcasts-and-videos.html.

The ESOP Association - http://www.esopassociation.org/.

National Centre for Employee Ownership - http://www.nceo.org/.

European Federation of Employee Share Ownership - http://www.efesonline.org/.

Ownership Associates - http://www.ownershipassociates.com/abt.shtm.

Venture Capitalist - http://www.avc.com/a_vc/stocks/. 
1. Employee Ownership Association (EOA), 'About Employee Ownership'. http://www.employeeownership.co.uk/employeeownership/about-employee-ownership/, accessed 7 May 2011.

2. Field Fisher Waterhouse, '2010 saw employee owned company shares outperform the FTSE All-Share according to Employee Ownership Index'. http://www.ffw.com/press-releases/2011/mar/employee-owned-company-shares.aspx, accessed 16 June 2011.

3. National Center for Employee Ownership (NCEO), 'A Statistical Profile of Employee Ownership' updated April 2011. http://www.nceo.org/main/article.php/id/2/, accessed 16 May 2011.

4. J. Knell, Share Value: How Employee Ownership is Changing the Face of Business (Herts: The All Party Parliamentary Group on Employee Ownership, 2008), p. 7.

5. J. L. Pierce and C. Furo, 'Employee Ownership: Implications for Management' Organizational Dynamics 18 (1990): $32-43$. See p. 35.

6. A number of plans exist in the UK to facilitate ownership of equity shares amongst employees. Share plans have received continuous government support over the past twenty years since they are a very tax-efficient way for a company to reward its employees. Details of these plans, such as the Share Incentive Plan (SIP), can be found at http://www.hmrc.gov.uk/shareschemes/.

7. Known as employee share ownership as opposed to employee ownership.

8. D. Rousseau and Z. Shperling, 'Pieces of the Action: Ownership and the Changing Employment Relationship' Academy of Management Review 28 (2003): 553-70.

9. E. Kaarsemaker, A. Pendleton, and E. Poutsma, 'Employee Share Ownership Plans: A Review' Working Paper 44. The York Management School, 2009, p. 3.

10. Kaarsemaker, Pendleton, and Poutsma, 'Employee Share Ownership Plans: A Review', p.37.

11. Rousseau and Shperling, 'Pieces of the Action: Ownership and the Changing Employment Relationship', p. 558.

12. See J. L. Pierce and L. Rodgers, 'The Psychology of Ownership and Worker-Owner Productivity' Group and Organisation Management 29 (2004): 588-613, for a discussion of the psychological aspects of employee ownership.

13. J. Nelson-Jones and G. Nuttall, Employee Ownership: Legal and Tax Aspects (London: Fourmat Publishing, 1987), p. 72.

14. Nelson-Jones and Nuttall, Employee Ownership: Legal and Tax Aspects, p. 76.

15. Nelson-Jones and Nuttall, Employee Ownership: Legal and Tax Aspects, p. 82. See chapter 8 for a discussion of the degeneration theory.

16. Nelson-Jones and Nuttall, Employee Ownership: Legal and Tax Aspects, p. 83.

17. D. Erdal, Beyond the Corporation: Humanity Working (London: The Bodley Head, 2011), pp. $38,48$.

18. Erdal, Beyond the Corporation: Humanity Working, p. 49.

19. J. Blasi, D. Kruse, and A. Bernstein, In the Company of Owners (New York: Basic Books, 2003), p. 16.

20. Erdal, Beyond the Corporation: Humanity Working, p. 50.

21. Blasi, Kruse, and Bernstein, In the Company of Owners, p. 148.

22. Blasi, Kruse, and Bernstein, In the Company of Owners, p. 170.

23. G. Nuttall and S. Anderson, Employee Benefit Trusts booklet (London: Equity Incentives, 2001$),$ p. 2.

24. Nuttall and Anderson, Employee Benefit Trusts booklet. p. 2.

25. Nelson-Jones and Nuttall, Employee Ownership: Legal and Tax Aspects, p. 96. See http://www.employeeshareschemes.co.uk/ plans-sip.aspx for information on the tax treatment of Share Incentive Plans (SIP) in the UK.

26. There are a number of tax efficiencies associated with transfer of shares to an EBT, specifically relating to inheritance tax and capital gains tax. For an overview of tax aspects of an EBT and the relevant legislation, such as the Inheritance Tax Act and the Finance Act, see Nelson-Jones and Nuttall, Employee Ownership: Legal and Tax Aspects, chapter 6.

27. Nuttall and Anderson, Employee Benefit Trusts booklet, p. 2.

28. Scott Bader, a chemical company operating globally, is wholly owned by a charitable trust, the Scott Bader Commonwealth Ltd Each year, at least sixty per cent of the company's profits must be reinvested in the business. The remaining profit must be split equally, half for distribution to the employees and half for charitable purposes.

29. R. Oakeshott, Jobs \& Fairness: The Logic and Experience of Employee Ownership (Norwich: Michael Russell, 2000$)$, p. 218.

30. Each branch of the company has a Partnership Councillor and Registrar, who make sure the integrity of the Partnership and the democratic structures within the company are upheld.

31. V. Pérotin and A. Robinson, 'Employee Participation in Profit and Ownership: A Review of the Issues and Evidence' Paper prepared for the European Parliament, December 2002, p. 2.

32. D. Erdal, Local Heroes: How Loch Fyne Oysters Embraced Employee Ownership and Business Success (London: Penguin Group, 2008), p. 175.

33. Baxi Partnership is a loan fund for prospective employee-owned companies. Baxi supplies capital for employee takeovers in the form of debt and also offers support services and training. The story of Baxi Partnership itself is a fascinating one and can be accessed at http://www.baxipartnership.co.uk/about-us/the-baxi-story/.

34. Erdal, Local Heroes, p. 181.

35. Blasi, Kruse, and Bernstein, In the Company of Owners, p. 167.

36. J. Logue and J. Yates, The Real World of Employee Ownership (New York: Cornell University, 2001$)$, p. 16. 
37. For a detailed analysis of the UK experience with ESOPs and share plans in general, see the work of Andrew Pendleton (2000-2005).

38. The ability of an ESOP to raise capital in the form of debt is considered one of its key advantages over other forms of employee ownership. It is usually not feasible for employees to collectively raise enough capital to purchase their company; a leveraged ESOP provides a way for employees to become company owners without using their personal income. The tax advantages of ESOPs can also make them one of the more cost effective vehicles for raising debt finance.

39. It has been suggested that accumulation of shares based on salary earned is an unfair system and only serves to further perpetuate the wage/salary inequality in firms by creating capital inequality.

40. National Center for Employee Ownership (NCEO), 'How an Employee Stock Ownership Plan (ESOP) Works'. http://www.nceo.org/ main/article.php/id/8/, accessed 23 May 2011.

41. Logue and Yates, The Real World of Employee Ownership, p. 16. It should be noted that employees in public companies who have shares in an ESOP are granted full voting rights.

42. In the US, legislation allows companies that are one hundred per cent owned by an ESOP to avoid paying federal income taxes.

43. If employees hold shares directly then they are entitled to one vote per share as is the norm. If the shares are held collectively on behalf of the employees, the governance structure of the company can take many forms, including the use of co-determination, worker-directors, and partnership councils.

44. The owners of a business may be attracted to employee ownership for altruistic reasons, such as the belief in a fairer system of capitalism through wealth distribution.

45. This exercise can also form the basis of a seminar. Having completed the exercise, place students into groups and encourage them to compare and analyse each other's results. Build a discussion around the questions in the exercise: is one company's form of governance superior to that of another? 


\section{An acceptable face of capitalism?: arguments for and against employee ownership}

'. .. the ultimate conclusion on the labour-managed firm is clear.

Whatever its contribution to industrial democracy, it is not an inherently efficient economic organisation.'

Eirek Furobotn ${ }^{1}$

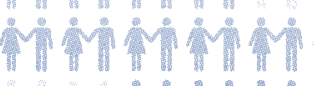

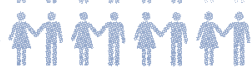

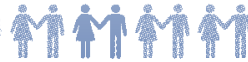

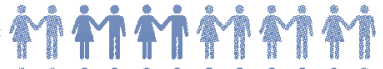

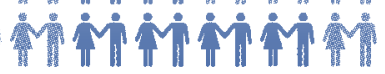

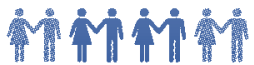

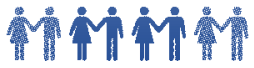

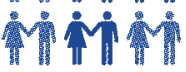

in

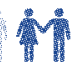

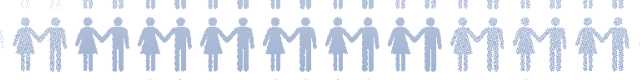

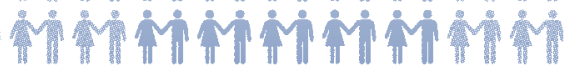

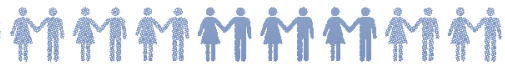

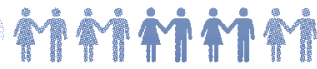

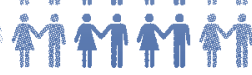

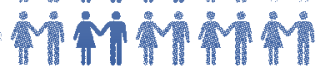

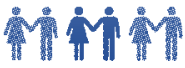

零

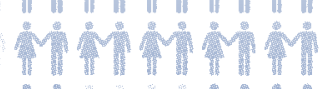

率

Min

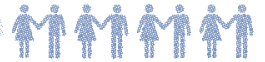

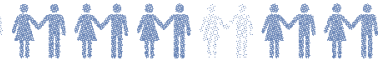
Mำ

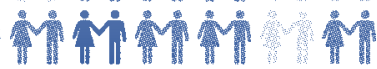

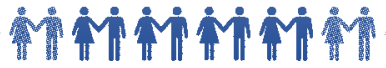
栾 M 


\section{An acceptable face of capitalism?: arguments for and against employee ownership}

\section{Learning objectives}

This chapter explores the arguments for and against employee ownership at both theoretical and practical levels. By the end of this chapter you will be able to:

- distinguish the economic, social, and political reasoning behind employee ownership;

- critically assess the theoretical and practical arguments for and against employee ownership.

The key arguments that will be developed in this chapter are:

The case for employee ownership must be argued on economic, social, and political bases.

The form of employee ownership in question must be taken into account when analysing the arguments for and against employee ownership.

The level of risk borne by workers in an organisation is a key component in most arguments.

The majority of benefits associated with employee ownership are only realisable through an ownership structure that combines meaningful financial participation with participation in management, decision-making, and governance.

\section{The case for employee ownership}

\section{'On the face of it, shareholder value is the dumbest idea in the world.'}

The following analysis is comprised of four parts:

- the case for employee ownership based on rights;

- the case for employee ownership based on economic benefits;

- the case for employee ownership based on social reasons;

- the case for employee ownership based on political reasons. 


\section{Rights}

The property argument of employee ownership rests on the inalienable right of workers to control their own actions; in essence, this means that it is impossible for a person to 'rent' themselves to a company. Workers also have the right to appropriate the fruits (positive and negative) of their labour. ${ }^{2}$ This idea is combined with the notion that employees bear risk in the organisation and should possess a right to the value generated by the firm as well as the right to participate in governance, to produce a strong argument for employee ownership based on organisational rights.

Dahl argued that democratic employee ownership, once it is efficient economically, is superior to other forms of organisation simply by virtue of its beneficial 'consequences for democracy and justice'. ${ }^{3}$

\section{Economic}

\section{Efficiency}

Despite being one of the major arguments against employee ownership, increased efficiency has also been used as a potential advantage of the model. Hansmann contends that there are efficiency advantages to be gained by having a workforce that has highly homogeneous interests. Homogeneous interests help to reduce agency costs (monitoring and supervision) and prevent the exploitation of employees by the company. ${ }^{6}$

\section{Case study 7.1 - Economic benefits of employee ownership}

A study published in 2010 of the economic benefits of employee ownership was conducted on behalf of the Employee Ownership Association (EOA) by researchers in the CASS Business School, London. The report is based on a survey of 41 Employee-owned Businesses (EOBs) and 22 non-EOBs in the UK. It also draws upon secondary data on the commercial performance of 49 EOBs and 204 non-EOBs in the UK. The following is a summary of some of the main findings of the report. ${ }^{4}$

- The employee ownership model offers particular advantages to small and medium-sized businesses. EOBs with fewer than seventy-five employees do significantly better than non-EOBs of the same size measured by both Profit Before Tax and Profit Before Tax per employee.

- The profitability of EOBs correlates with giving employees greater autonomy in decisionmaking. EOBs that adapt their organisational structure and empower their front-end employees are more likely to sustain their performance as their size increases.

- As EOBs grow in size they need to find innovative ways to involve staff. EOBs with higher employee numbers experience lower levels of employee involvement in new product decisions and strategy. As EOBs grow in size, it is vital to seek new ideas from staff and involve them in key business area decisions.

- EOBs and non-EOBs are on a par for profitability, measured by Profit Before Interest and Taxes (PBIT) ${ }^{5}$ : non-EOBs performed slightly better on this measure between 2005 and 2008, but EOBs outperformed non-EOBs in the period of recession during 2008-09. Non-EOBs performed significantly better than EOBs on PBIT per employee during the period 2005-8, but the gap narrowed in 2008-9. Analysis of survey responses shows that EOBs with high profit per employee give employees greater autonomy in the workplace and are more likely to seek innovative ideas from employees.

Source: J. Lampel, A. Bhalla, and J. Pushkar, Model Growth: Do Employee-Owned Businesses Deliver Sustainable Performance? (CASS Business School London. EOA Report, 2010) 


\section{Productivity}

The strongest economic argument for employee ownership focuses on the increases in productivity which result from meaningful financial and governance participation in an organisation. Jones investigated the effects of worker representation on the boards of British consumer co-operatives and found that productivity increased between 0.78 per cent and 1.4 per cent. These increases were achieved without any financial ownership on the part of the worker representatives. In a similar study, Doucouliagos found that:

worker participation in decision-making in LMFs (labour-managed firms) has a small, positive, and statistically significant association with productivity, rejecting the traditional view that democratic management of the firm is associated with reduced efficiency.7

This argument is echoed by Ricketts:

The principle advantage of the cooperative enterprise has long been considered the more positive motivation of the workforce and the absence of 'alienation' that is said to afflict workers in joint-stock enterprises. ${ }^{8}$

The key point regarding the productivity and performance benefits of employee ownership is the importance of combining financial participation (that is, sharing in profit or owning stock) with participation in management, decision-making and governance. ${ }^{9}$ Various studies and reports have highlighted this requirement as the single most important factor in harnessing the power of employee ownership. Not only is participation in governance central to achieving the benefits of employee ownership, it also acts as a deterrent for negative behaviours. According to Pérotin and Robinson:

Insufficient information and participation in governance might leave employees vulnerable to moral hazard and lead to conflict with management. ${ }^{10}$

One of the crucial elements in achieving employee participation in management, governance and decision-making is creating what is known as an ownership culture; employees need to feel they are owners.

\section{Case study 7.2 - The Essentials of an Ownership Culture}

Research shows that employee ownership is a powerful tool to improve corporate performance, but only when paired with what the National Center for Employee Ownership (NCEO) calls an 'ownership culture'. To unleash the benefits of employee ownership six essential 'rules' should be followed:

1. Provide a financially meaningful ownership stake, enough to be an important part of employee financial security.

2. Provide ownership education that teaches people how the company makes money and their role in making that happen.

3. Share performance data about how the company is doing overall and how each work group contributes to that performance.

4. Train people in business literacy so they understand the numbers the company shares.

5. Share profits through bonuses, profit sharing or other tools. 
6. Build employee involvement not just by allowing employees to contribute ideas and information but making that part of their everyday work organization through teams, feedback opportunities, devolution of authority, and other structures.

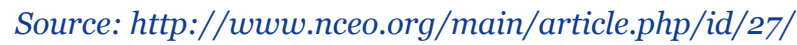

Alignment of employee interests with the firm

For organisational theorists and management specialists, employee ownership is often put forward as a means of aligning the interests of workers with those of the shareholders. ${ }^{11}$ This argument arose out of the Principal/Agent theory of employment relationships. The principal (owner) needs the agent (employee) to do something for him/her, such as to complete a task. The agent possesses more information than the principal and has different interests (moral hazard). Therefore the agent must be rewarded with appropriate incentives or subjected to strict monitoring (which is costly) to ensure he or she performs the task. Disseminating a piece of ownership amongst employees helps to reduce these agency costs. This argument is widely used as the basis for minority employee ownership most commonly found in companies whose shares are tradable on a stock market.

\section{Reduced supervision costs}

It is widely believed that raised levels of employee ownership, where the majority of workers participate in ownership, help to foster a culture of peer supervision, driven by the need to ensure everyone is contributing to the success of the business. Rather than use management authority or direct commands, employees will use social pressure to encourage each other to perform to a high level. ${ }^{12}$

\section{Employment}

Blair, Kruse, and Blasi proposed that employee-owned companies will tend to maintain employment levels better during periods of economic hardship:

An alternative argument in favour of employee ownership comes out of the idea that participatory firms, for cultural and economic reasons, will have less tendency to lay off workers during economic downturns. ${ }^{13}$

Lampel, Bhalla, and Pushkar extend this argument by empirically demonstrating that employeeowned firms not only retain employment levels better, but also create jobs at a faster rate:

EOBs create jobs faster. EOBs experienced greater employment growth than their nonemployee-owned counterparts in the period of economic growth from 2005 to 2008 (an average increase in employment of nearly 7.5\% per annum in EOBs compared with less than $3.9 \%$ in non-EOBs). After the recession set in during 2008-09, this rate increased even faster, with EOBs increasing employment numbers by more than $12.9 \%$ compared with $2.7 \%$ in non-EOBs. This is reflected in the belief of EOBs that staff recruitment and retention are crucial in economic recovery: nearly three-quarters of EOBs strongly believe that employee commitment is a central advantage of the employee-owned model. ${ }^{14}$

\section{Stability}

Research in the US has shown that employee ownership can 'stabilise' a firm by lowering the probability of the firm being taken over, going bankrupt, or taken private; it can also maintain employment levels. None of this comes at any economic cost (for example, lower productivity). Blair, Kruse, and Blasi compared twenty-seven public firms which had at least twenty per cent employee ownership with forty-five similar-sized non-employee-owned firms. They found that only one employee-owned company was taken over by new owners compared with ten of the forty-five 
non-employee-owned firms. They also found that EO firms performed at least as efficiently as the non-EO firms. ${ }^{15}$

The findings of this research were corroborated by a similar study in the UK. Lampel, Bhalla and Pushkar concluded:

EOBs (employee-owned businesses) are more resilient: their performance is more stable over business cycles, displaying less sales variability. During the period of growth from 2005 to 2008, non-EOBs experienced higher average sales growth per annum (12.1\%) than EOBs (10.0\%).

However, the average sales growth of EOBs between 2008 and 2009 was $11.08 \%$, significantly surpassing that of non-EOBs (0.61\%) during this period of recession. ${ }^{16}$

\section{Innovation}

A common argument against employee ownership concerns the perception of barriers to innovation. The empirical evidence, however, suggests that employee-owned companies are more likely to be innovative than not. A report by the All Party Parliamentary Group on Employee Ownership conducted in 2008 states:

co-owned companies are more likely to adopt human resource practices of employee participation and representation, and these in turn have been found to be positively and statistically significantly correlated with the probability of firms innovating. ${ }^{17}$

The report highlights that employee-owned companies are more likely to adopt participatory management practices as well as granting greater autonomy to employees. This in turn helps to create a working environment which is more conducive to innovation and creativity. There is also a tangible benefit for employees to be innovative because they will share financially in the commercialisation of new ideas.

UBH International, one of the world's leading specialist manufacturers of transportable tanks for bulk liquids, is an excellent example of the entrepreneurial nature of workers in an employeeowned company. UBH presented evidence to the same parliamentary report on the effects employee ownership had on innovation within the company:

In general [we] have found that change can be implemented more successfully and with high levels of employee participation in co-owned companies because there is a clear linkage between innovation and change and individual benefit. ${ }^{18}$

Another empirical example of the innovative nature of employee-owned companies is the American company EBO (Excellence by Owners):

We are a 100\% employee owned company guided by a defining set of shared values.

Our unique ownership culture empowers us to strive for excellence and achieve extraordinary customer service. We encourage and promote the incubation of new ideas, processes and products. For over 30 years, we've all shared in the successful creation and growth of our companies. Our employee owners enjoy investing their time, talents, energy and passion in becoming entrepreneurs and venture capitalists in each new opportunity. ${ }^{19}$

From one business in 1978, EBO has grown to four companies, all of which were created using a unique innovation framework consisting of an ownership culture, shared values, and the EBO process for generating new ideas. 


\section{Case study 7.3 - \\ Financial performance of employee-owned companies in the UK}

The UK Employee Ownership Index, maintained by legal advisors Field Fisher Waterhouse, is an index of the share prices of UK public companies quoted on the London Stock Exchange and AIM which have ten per cent or more of their issued share capital held by or on behalf of employees other than main board directors. The performance of the index is calculated quarterly. Started in 1995, the index has outperformed the FTSE All-Share (London Stock Exchange) index over three, five and ten years. In 2010, for example, employee-owned companies' share prices were up 16.3 per cent over the year, compared with 11.3 per cent for the FTSE-All Share companies' share prices.

Source: http://www.ffw.com/practices/employment-pensions-incentives /equity-incentives/uk-employee-ownership-index.aspx.

\section{Social}

A more equitable society?

One of the key issues in developed countries today is the growing divide between the richest and the poorest individuals in society. Wilkinson and Pickett suggest that employee ownership may be a way of alleviating these wealth inequalities. They argue that employee ownership is a way of creating a more egalitarian society based on the following advantages:

- it is a form of social emancipation (giving rights to employees);

- democratic control of pay differentials;

- redistribution of wealth and income;

- improved productivity; possible competitive advantage;

- increases experiences of community;

- improves sociability in society. ${ }^{20}$

The role of employee ownership in community regeneration, both socially and economically, should not be underestimated. Employee ownership grounds local businesses in the community, providing employment as well as distributing wealth in the local economy. Case study 7.4 provides empirical evidence of the social benefits of having more employee ownership in communities. 


\section{Case study 7.4 - \\ Social impact of employee ownership: evidence from Italy}

In 1999 David Erdal conducted a study of three Italian towns in the region of Bologna:

Imola, Faenza, and Sassuolo. These towns had twenty-six per cent, thirteen per cent and zero per cent respectively of the working population employed in worker co-operatives. He sought to explore the effects of having a more egalitarian society by studying the effect worker ownership had on each town based on the following metrics:

Crime

victimisation; policing; confidence; feeling of security; and domestic violence.

\section{Education}

level attained; age leaving school; truancy; expected truancy; post-school training; and perceived importance of education.

Health

physical health; emotional health; and mortality.

Social environment

perceived gap between rich and poor; helpfulness of authorities; and supportiveness of social networks.

Social participation metrics

membership of clubs; voting rates; and blood donation.

Erdal found that the towns with a greater percentage of citizens working in co-operatives performed better in terms of mortality (they lived 2.5 years longer), donating blood, and voting at local and national elections, as well as in all of the other metrics bar one. He concluded that 'an economy with a moderate to high level of worker co-operatives' produces significant beneficial effects in the wider community - better health and education, lower levels of crime, higher levels of social participation and increased appreciation of the social environment.

Source: D. Erdal, Beyond the Corporation: Humanity Working (London: The Bodley Head, 2011), pp. $239-241$. Erdal, D. (1999). The wider social effects of worker co-operatives. Extract from PhD thesis.

\section{Benefits to individual employees}

Klein identified three ways in which employee ownership affects attitudes:

Intrinsic satisfaction

ownership per se is sufficient to bring about attitudinal and behavioural change;

Extrinsic satisfaction

ownership leads to attitudinal and behavioural change because it is financially rewarding; and

Instrumental satisfaction

ownership brings about attitudinal and behavioural change by facilitating other outcomes that are desired by employees such as participation in decision-making. ${ }^{21}$ 
All of these behavioural changes can lead to more productive, satisfied and less stressed employees. Employee ownership also tends to remove the one-dimensional authority relationship between managers and workers commonly found in more conventional firms. ${ }^{22}$

\section{Political}

Dahl argues that economic democracy is justified on two theoretical grounds which require more extensive empirical testing:

- Democratising enterprises will produce more politically conscious and active citizens, resulting in numerous 'positive externalities'. ${ }^{23}$

- If the democratic process is deemed necessary at a state level, then it should also be the de facto governance system for enterprises. ${ }^{24}$

The second point is echoed by Dow, who also claims that firms should mirror the government in terms of their democratic governance structures. Increased participation in community and political life will generate positive externalities for society (see some of the social arguments above). ${ }^{25}$ Dow provided a caveat, however, stating that direct democracy in the governance of a company can sometimes force a trade-off with economic efficiency.

\section{The case against employee ownership}

Most arguments against employee ownership derive from the theories of economists who have applied models normally used for the study of investor-owned businesses. Some of these arguments are not specific to employee-owned companies, while others raise important issues of which employee-owners should be aware.

\section{Horizon problem}

According to some analysts, employee-owned companies are liable to under-invest in the business for a reason known as the horizon problem. Take a worker co-operative with a sizeable proportion of the membership approaching retirement age. The horizon problem states that these members would oppose any investment decisions in the business where the return-on-investment period is greater than the remaining years of their employment. Put simply, why should an employee-owner forgo participating in the surplus of the business in the present for an investment that they will not benefit from because they will have left the company? This point was first raised by Jaroslav Vanek in 1970 and has since been echoed by other researchers. ${ }^{26}$

A counter-argument to this problem was put forward by Dahl. He argues that workers stand to lose a lot more than investors in a conventional company by extracting all of the value (surplus) of the firm. Generally, it is much easier for an investor to enter and exit the stock market than it is for a worker to enter and exit the job market. ${ }^{27}$ There is also the argument, reinforced by the economic crisis enveloping the global economy at the time of writing, that the need for employee-owners to secure their employment is an incentive to invest for the future. Although the horizon problem can be associated with employee-owned businesses, it is certainly not exclusive to them. ${ }^{28}$ 


\section{Shirking}

Another argument against worker co-operatives and employee-owned businesses was advanced by Alchian and Demsetz. According to these authors, workers in an employee-owned company have an incentive to shirk (not perform) because their effort only has a proportional effect on the work completed by the members. We have seen that a member of a worker co-operative shares in the surplus of the business on a proportional basis; they get $1 / n$ of the surplus, where $n$ is the number of members. The same logic applies to a worker whose efforts or productivity cannot be easily distinguished from the work of the group; that worker will only share in the cost of shirking on a proportional basis $(1 / \mathrm{n})$ rather than bearing the full costs. ${ }^{29}$ While theoretically plausible, it is also a problem likely to afflict conventional models of enterprise. Workers in an investor-owned firm possess an incentive to shirk because their efforts do not produce any tangible return outside of their wages (hence the need for strict supervision).

\section{Inefficient}

One of the most common and fiercely debated criticisms of employee ownership focuses on its apparent economic inefficiencies. Efficiency in an economic sense refers to the ability of a business to utilise the fewest amounts of inputs to produce an output. Commentators argue that employeeowned businesses will not be efficient in this manner. Two of the critics, Jensen and Meckling, base their argument on the fact that employee ownership and industrial democracy rarely occur spontaneously and need legislative support to develop. ${ }^{30}$

Interestingly, however, these authors do note that the businesses would not exist if they were inherently inefficient:

competition in the establishment of organizational forms coupled with voluntary choice on the part of workers and capital suppliers regarding which organization they "join" will ensure that neither organizational form will be significantly less productive than the other-otherwise it would be driven out of existence..$^{31}$

The point to bear in mind is that employee ownership is only considered inefficient because it does not add any value for shareholders. Employee ownership does not need to be economically superior (though evidence has already been provided that it can be); instead industrial democracy and employee ownership can be seen as worthwhile objectives in themselves.

\section{Control}

The term control in this context refers to the ability of the employee-owners to reach decisions effectively and to direct the firm in pursuit of common objectives. Hansmann argues that collective decision-making costs for employee-owned companies will be high, due to the heterogeneous interests of the workers, making employee ownership impractical and inefficient. ${ }^{32}$ Ricketts supports this argument, stating that the costs of reaching agreement in the firm are high. ${ }^{33}$ For employee-owned businesses, it is important to ensure that a proper governance system is in place, as well as employee participation practices. Case study 7.5 highlights one of the more successful experiences of collective decision-making in an employee-owned company. 


\section{Case study 7.5 - The power of sharing information}

The extended version of this case study can be found on the VLE.

Tullis Russell, a paper manufacturer based in Fife, is one of Scotland's largest and most successful employee-owned companies. In 2002, the company was faced with a tough decision regarding the fate of one of its factories in Stoke. The company's culture of employee participation, engagement, and most importantly sharing of information, allowed it to reach a decision that not only minimised the impact of the factory closure but was actually endorsed by the employees.

\section{Background}

One of Tullis Russell's most profitable and successful product offerings was a highly specialised premium paper used to transfer designs onto ceramic objects, such as cups and plates. The company established a manufacturing plant to develop this type of paper in Stoke-on-Trent, an area in the west midlands of England famous for its pottery factories. During the 1990s, however, this division of the company came under increased competition from manufacturers in South Korea, who had rapidly expanded to capture a large segment of the enormous Chinese ceramics market. In order to stay competitive and expand the business, the board of directors knew they had to capture some of the Chinese market, as the UK market (in particular the Stoke-on-Trent potteries) had shrunk in the face of intense competition from the east. In 2002, eight years after the company became employee-owned, an opportunity arose to acquire a Korean manufacturer which had recently declared itself bankrupt. The board felt that the acquisition made good economic sense for the company, but was aware of the impact it would have on the Stoke plant and its employee-owners. Their decision could be vetoed by the elected body of employees, consisting of fourteen employee-owners (including two from the Stoke plant) representing every employee in the company. How would the employees vote?

\section{The power of engaged employees}

The decision surprised the board. The elected body voted unanimously in favour of the acquisition. This decision would baffle traditional economists and trade union leaders. Surely the employees would preserve their self-interest by vetoing the decision and protecting the Stoke factory? The unanimous decision by the elected body put paid to this notion; and to prove that this was not an aberration, the elected body made the exact same decision when asked to vote on the board's suggestion to close the Stoke plant altogether. The elected body again acted in the best interest of the company. This can only be explained by the employees' high level of engagement with the company. Managing Director (MD) Fred Bowden, who subsequently went on to become chairman, had instilled in the company's management the need to inform and engage employees at every level. Information regarding the company's performance, strategic decisions and other important policy matters was shared with every employee at regular intervals. The relationship between the company and its employees was underlined further when, after setting a timescale of fourteen months for the closure, it was agreed to brief the employees in Stoke immediately to allow as much time as possible for assistance with retraining and employment opportunities.

Source: D. Erdal, Beyond the Corporation: Humanity Working (London: The Bodley Head, 2011), pp. 79-83.

\section{Raising finance}

Another common argument against co-operative and employee-owned enterprises is the perceived inability of these businesses to raise sufficient levels of capital. According to Blair, Kruse, and Blasi: 
Since employees as a class are generally not wealthy, they are likely to be risk averse and liquidity constrained. Hence they might have trouble assembling enough equity capital to provide sufficient financing for their firm, especially in capital-intensive industries. And if they try to finance their firm with debt capital, they are likely to face a higher cost of capital than a similarly situated firm financed with equity capital because of the inherent moral hazard problems debt financing would involve. These factors suggest that, if employee ownership is viable at all, it is likely to be in low capital-intensity industries. ${ }^{34}$

Jensen and Meckling express doubt over whether an investor would trust an employee-owned firm with its capital:

It is highly unlikely that potential investor demands for the residual claims on a labor-managed firm would be large without some sacrifice of the control right by the workers. It seems to us unlikely that outside investors would voluntarily entrust their funds to a labor-managed enterprise in which the workers maintained complete control and the investors were allowed to hope that the worker-managers would behave in such a way as to leave something for them, the residual claimants. ${ }^{35}$

The problem of raising finance is intensified by the lack of specialist advice and understanding amongst financial, legal and political experts:

EOBs have difficulties obtaining favourable financing from institutions that are more accustomed to dealing with listed companies. Lack of specialist support from business advisers during transition to employee ownership is also a problem..$^{36}$

Ricketts provides a counter argument, highlighting the fact that employee-owned businesses should have no problem raising debt as the payment of interest on the capital ranks ahead of the workers' claim on the surplus. He suggests that employee-owned businesses will have no problem raising finance if they have non-firm-specific assets, since these assets can be easily sold, and have firm-specific skills making it difficult for the workers to move to another company. ${ }^{37}$

\section{Common property}

Commonly known as the 'free-rider' problem, this argument stems from the collective ownership nature of an employee-owned firm. Take a company that has been in operation for five years. The original members have built up the value and assets of the company. When a new member/ employee is hired, they have the same claim as previous members/employees to the cash flows of any previous investment made by the business. New members/employees, in a sense, are 'free riding' on the back of the hard work of other members/employees..$^{38}$

This argument lacks context, however, as it does not make reference to the time horizon of free riding. Consider an employee who has worked in a company for fifteen years; it is reasonable to assume that the employee has contributed to the cash flows of the business and is not 'free riding' anymore. This issue only really applies in the first number of years in an employee-owned company's existence and there is an argument for ensuring the founders are adequately rewarded for their entrepreneurial drive and investment. 


\section{Portfolio problem}

Workers in an employee-owned business commit capital to the firm in order to purchase ownership or support operations. The argument for investor-owned businesses lies with their efficient, risk-bearing model of ownership. Investors are able to spread their capital amongst a number of businesses, thereby reducing the impact of one of their investments failing. This key tenet of investing is known as diversification. For an employee-owned business, critics argue that workers cannot diversify their investment in the company (at best, they can only work for a few companies at one time) and so are fully exposed to the risk of the business failing. Coupled with the fact that employees generally have very little capital with which to commit to the company, we arrive at a very inefficient model of risk-bearing. ${ }^{39}$

In companies where employees use their share of the surplus to invest further in the business, the risk exposure of the workers does increase compared to using the money to create a diverse portfolio of investments. As with any form of investment, competent advice should be sought.

\section{Summary of learning}

This chapter has argued that:

- Employee-owned enterprises represent a sound model of ownership on social and political grounds.

- Employee-owned companies are at least as efficient economically as investor-owned businesses.

- The major economic benefits of employee ownership can only be realised by combining financial participation in ownership with participatory management practices and a role in the governance of the organisation.

- Risk is a major aspect of the arguments for and against employee ownership. Arguments for employee ownership centre on the risk to employees of supplying labour to the organisation. Arguments against focus on the unsuitability of employees to bear risk due to capital constraints and an adverse attitude to risk.

- Many of the theoretical arguments for and against employee ownership are only applicable to certain forms of employee ownership, and cannot be used as a 'broad brush' treatment of the topic.

\section{Essay/discussion questions}

- 'Employee ownership is a positive thing for society.' Discuss this statement with reference to the normative and empirical arguments outlined in this chapter, as well as evidence derived from your own research.

- Is there a case to be made for political support for employee ownership?

- Could it be argued that certain forms of employee ownership are only a means of reducing trade union power and encouraging employees to generate even more wealth for shareholders? 
The Carey Center for Democratic Capitalism - http://www.democratic-capitalism.com/.

The MIT Community Innovators Lab - http://colabradio.mit.edu/.

The Capital Ownership Group - http://cog.kent.edu/.

\section{Endnotes}

1. E. G. Furobotn, 'The Long-Run Analysis of the Labor-Managed Firm: An Alternative Interpretation' The American Economic Review 66 (1976): 104-23.

2. G. Dow, Governing the Firm: Workers Control in Theory and Practice (Cambridge: Cambridge University Press, 2003 ), p. 33.

3. R. A. Dahl, A Preface to Economic Democracy (Berkeley: University of California Press, 1985), p. 93.

4. J. Lampel, A. Bhalla, and J. Pushkar, Model Growth: Do employee-owned businesses deliver sustainable performance? (London: Employee Ownership Association, 2010).

5. Readers should note the difference in terminology between Profit Before Tax and Profit Before Interest and Tax; this difference is the work of the authors of the study but should not detract from the underlying analysis.

6. H. Hansmann, The Ownership of Enterprise (Cambridge: Harvard University Press, 1996), p. 119.

7. C. Doucouliagos, 'Worker Participation and Productivity in Labor-Managed and Participatory Capitalist Firms: A Meta-Analysis' Industrial and Labor Relations Review 49 (1995): 58-77. See p. 68.

8. M. Ricketts, The Economics of Business Enterprise (Cheltenham: Edward Elgar, 2002), p. 348.

9. J. L. Pierce and C. Furo, 'Employee Ownership: Implications for Management' Organizational Dynamics 18 (1990): 32-43; D. Rousseau and Z. Shperling, 'Pieces of the Action: Ownership and the Changing Employment Relationship' Academy of Management Review 28 (2003): 553-70; R. Oakeshott, Jobs \& Fairness: The Logic and Experience of Employee Ownership (Norwich: Michael Russell, 2000); J. Logue and J. Yates, The Real World of Employee Ownership (New York: Cornell University, 2001); V. Pérotin and A. Robinson, 'Employee Participation in Profit and Ownership: A Review of the Issues and Evidence' Paper prepared for the European Parliament, December 2002; W. Davies, Reinventing the Firm (London: Demos, 2009). A detailed study of the issues surrounding employee participation in the firm is J. Hyman and B. Mason, Managing Employee Involvement and Participation (London: Sage, 1995). Hyman and Mason outline the key concepts and philosophies, practical methods for implementing participation practices, and the response of employees to involvement and engagement.

10. Pérotin and Robinson, 'Employee Participation in Profit and Ownership', p. 3.

11. M. Blair, D. Kruse, and J. Blasi, 'Is Employee Ownership an Unstable Form? Or a Stabilizing Force?' in T. Kochan and M. Blair (eds), The New Relationship: Human Capital in the American Corporation (Washington: The Brookings Institution, 2000), p. 246.

12. Blair, Kruse, and Blasi, 'Is Employee Ownership an Unstable Form? Or a Stabilizing Force?' p. 247.

13. Blair, Kruse, and Blasi, 'Is Employee Ownership an Unstable Form? Or a Stabilizing Force?' p. 248.

14. Lampel, Bhalla, and Pushkar, Model Growth: Do employee-owned businesses deliver sustainable performance?

15. Blair, Kruse, and Blasi, 'Is Employee Ownership an Unstable Form? Or a Stabilizing Force?'

16. Lampel, Bhalla, and Pushkar, Model Growth: Do employee-owned businesses deliver sustainable performance?

17. J. Knell, Share Value: How Employee Ownership is Changing the Face of Business (Herts: The All Party Parliamentary Group on Employee Ownership, 2008), p. 12.

18. Knell, Share Value: How Employee Ownership is Changing the Face of Business, pp. 11-12.

19. http://www.ebogroupinc.com/.

20. R. Wilkinson and K. Pickett, The Spirit Level: Why Equality is Better for Everyone (London: Penguin Group, 2010), p. 260.

21. K. Klein, 'Employee Stock Ownership and Employee Attitudes: A Test of Three Models' Journal of Applied Psychology 72 (1987): 319-32.

22. Dow, Governing the Firm: Workers Control in Theory and Practice, pp. 35-6.

23. A positive externality is an economic term for a side effect of economic activity. A company that generates a positive externality does not receive any payment; it is also known as a spill-over or third-party effect.

24. Dahl, A Preface to Economic Democracy, p. 94.

25. Dow, Governing the Firm: Workers Control in Theory and Practice, pp. 27-32.

26. M. C. Jensen and W. H. Meckling, 'Rights and Production Functions: An Application to Labor Managed Firms and Codetermination' Journal of Business 52 (1979): 469-506; M. Mellor, J. Hannah, J. Stirling, Worker Cooperatives in Theory and Practice (Milton Keynes: Open University Press, 1988); M. Blair, D. Kruse, and J. Blasi 'Is Employee Ownership an Unstable Form? Or a Stabilizing Force?' in T. Kochan, and M. Blair (eds), The New Relationship: Human Capital in the American Corporation (Washington: The Brookings Institution, 2000); M. Ricketts, The Economics of Business Enterprise (Cheltenham: Edward Elgar, 2002). 
27, R. A. Dahl, A Preface to Economic Democracy, p. 123.

28. The corporate governance failures of Enron and WorldCom in the early 2000 s, coupled with the short-term investment horizons adopted by the majority of investment banks that precipitated the financial crisis of 2007, indicate that this argument is applicable to other models of enterprise.

29. A. A. Alchian and H. Demsetz, 'Production, Information Costs, and Economic Organization' American Economic Review 62 (1972): 777-95. See p. 782.

30. M. C. Jensen and W. H. Meckling, 'Rights and Production Functions: An Application to Labor Managed Firms and Codetermination' p. 476. The authors are specifically referring to practices in Europe such as codetermination (that is, worker representation at board level). Germany was one of the first countries to create specific codetermination laws, requiring all companies with more than 500 employees to have worker representation on the board.

31. Jensen and Meckling, 'Rights and Production Functions: An Application to Labor Managed Firms and Codetermination' p. 45.

32. Hansmann, The Ownership of Enterprise, p. 90.

33. Ricketts, The Economics of Business Enterprise, p. 353.

34. Blair, Kruse, and Blasi, 'Is Employee Ownership an Unstable Form? Or a Stabilizing Force?' p. 245.

35. Jensen and Meckling, 'Rights and Production Functions: An Application to Labor Managed Firms and Codetermination', p. 27.

36. Lampel, Bhalla, and Pushkar, Model Growth: Do Employee-Owned Businesses Deliver Sustainable Performance? p. 5.

37. Ricketts, The Economics of Business Enterprise, pp. 350-1.

38. Jensen and Meckling, 'Rights and Production Functions: An Application to Labor Managed Firms and Codetermination' p. 23.

39. A. Pendleton, 'The Costs and Benefits of Employee Ownership' extract from inaugural lecture 'When Workers Own Business: What Happens, and Why' at the University of York, 14 December 2009. http://www.youtube.com/watch?v=p6wFGquERLk, accessed 4 July 2011. 


\section{The rise and fall of industrial democracy: employee ownership and the business cycle}

'If you want to be incrementally better:

Be competitive. If you want to be

exponentially better: Be cooperative.'

Anon.

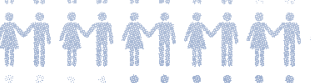

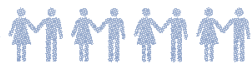

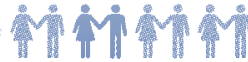

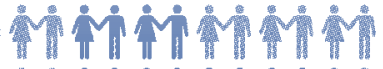

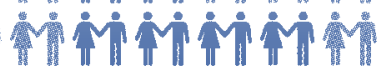

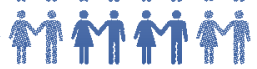

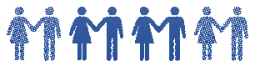

Mivip

in

iัต

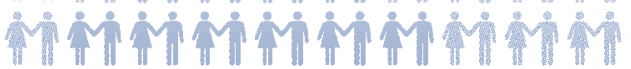

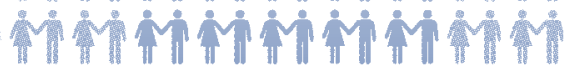

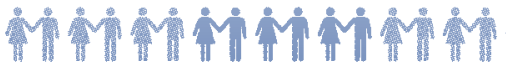

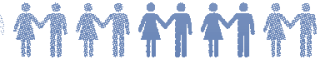

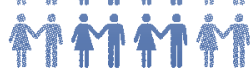

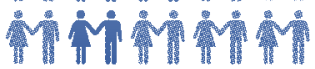

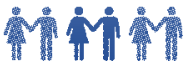

în

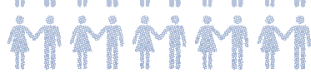

ini

Min

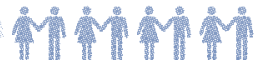

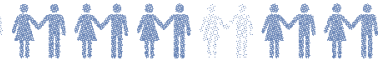
Mํํำ

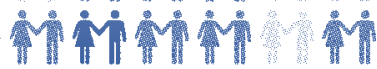

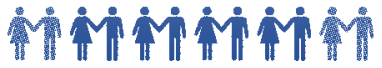
栾 M 


\section{The rise and fall of industrial democracy: employee ownership and the business cycle}

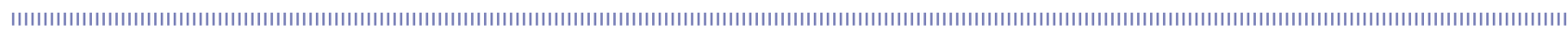

\section{Learning objectives}

This chapter examines aspects of the employee ownership lifecycle, particularly what happens at the formation and decline phases. There are various theories relating to supposed weaknesses of employee-owned firms and these will be assessed with reference to empirical evidence. By the end of this chapter you will be able to:

- demonstrate understanding of the mechanisms and rationale of establishing employee-owned firms;

- analyse core concepts and theories relating to the demise of employee-owned companies;

- articulate how employee-owned firms progress through the business cycle.

The key arguments that will be developed in this chapter are:

The rationale and mechanisms for establishing employee-owned companies differ depending on the form of employee ownership.

Employee-owned firms face specific problems at the formation stage compared with other forms of enterprise.

Employee-owned firms do not possess certain traits that make business failure inevitable.

Democratic structures and worker control do not necessarily diminish as a result of adopting more conventional organisational characteristics.

\section{Formation}

Employee-owned firms are often established using the same mechanisms as conventional forms of enterprise: they are established as new firms by a group of entrepreneurs, through conversions of existing businesses, and as viable succession strategies when existing owners wish to retire. However, the rationale underpinning employee ownership formation is different from that in conventional companies. This section will present some examples of how employee-owned firms are formed and also the reasoning behind their formation. 


\section{Start-up}

Like other forms of enterprise, employee-owned companies can be formed as new businesses. However, the drivers behind establishing an employee-owned company tend to be different from those in conventional firms. Ideological reasons, such as a strong belief in industrial democracy or ethical business practices, are usually the rationale for establishing an employee-owned firm as a new business. Correcting a market failure is often the rationale for establishing a worker co-operative; many SME worker co-operatives were established as a means to share risk and pool skills and resources during periods of high unemployment. The process and circumstances of creating an employee-owned business are also distinct from other forms of enterprise (for example, there needs to be a group of entrepreneurs rather than a sole individual). Annual formation rates of employee-owned firms as new businesses are difficult to estimate due to the absence of consistent and robust statistics. It is safe to say, however, that the annual rate of formation of employee-owned businesses is a small fraction of that for conventional companies. Some possible explanations for this will be put forward later in the chapter.

\section{Business succession}

This method of employee ownership formation is promoted as one of the better opportunities for establishing employee-owned companies by many of the development agencies in the UK, Europe, and the US. Business succession is a crucial topic for existing owners of SMEs. Employee ownership offers a well-established succession strategy for existing owners who wish to see the business continue trading in its current form and location. Formation rates via this method are rising; in most cases an altruistic or philanthropic owner is involved.

Employee ownership through business succession could play a vital role in the UK as a means of ensuring organisational sustainability. Statistics from 2009, published by the Department for Business, Innovation, and Skills, show that 99.9 per cent of businesses in the UK are SMEs. This accounts for 59.4 per cent of total private sector employment. ${ }^{1}$ The vast majority of these enterprises have less than nine employees. This represents an opportunity for business owners to reward their close network of employees and ensure business continuity by transferring ownership of the company to staff.

\section{Case study 8.1 - Childbase}

Childbase, an operator of children's nurseries in the south of England, successfully transferred ownership of the company to employees using a dual approach. In 2007, a new memorandum and articles of association were drafted identifying the employees as the primary beneficiaries of the business. An employee ownership structure was created using a combination of an employeebenefit trust (EBT) and individual employee shareholdings (maximum individual holding of 2.5 per cent). Childbase has financed the acquisition and distribution of company shares to employees by using profits to purchase shares from the previous owners.

Source: A. Bibby, From colleagues to owners: transferring ownership to employees (London: Employee Ownership Association, 2009). 


\section{Worker takeover}

The rationale for employee ownership through worker takeovers of existing firms is usually based on the need to protect local economies and levels of employment. Worker takeovers are more likely to occur in conventional firms that are struggling financially or generating an insufficient level of profit. This is because the value of the company is reduced in such circumstances (meaning the employees need less capital to finance the takeover), and also because firms generating large profits are unlikely to be relinquished by their owners. Employees more commonly demand wage increases rather than equity in a profitable firm; this highlights the lack of education and knowledge about the structure and benefits of employee ownership. ${ }^{2}$

There are three types of worker takeover:

Conversions $\quad$ - where workers take over a business before it begins to fail, but often when its financial position is beginning to weaken. Conversions usually occur in response to crises in business succession, such as the death of an owner.

Phoenix - $\quad$ refers to worker takeovers where a new business is created using some or all of the residual assets of a failed company.

Rescue $\quad-$ the company becomes worker-owned in response to a crisis such as bankruptcy. ${ }^{3}$

There is another form of employee ownership conversion similar to that of a worker takeover but is instigated not by the workers but by the current owners of the business. For example, Clansman Dynamics, an engineering and manufacturing business based in East Kilbride, a suburb of Glasgow, converted to employee ownership not in response to worker demand or outrage at the current plight of the business but rather by one of the founders and majority shareholders. Very often, the owner will be ideologically disposed to the concept of employee ownership, rather than driven by the need to generate benefits for themselves through employee ownership.

\section{Case study 8.2 - Occupy, Resist, and Produce: the case of Argentinean worker co-operatives}

The most notable recent example of worker takeovers of bankrupt or defunct businesses took place in Argentina during the early 2000s. The growth of worker co-operatives in Argentina was fuelled by the economic hardships created by the capitalist policies of then president Carlos Menem. When Argentina defaulted on its sovereign debt in 2002, protests occurred across the country and a worker movement was born.

The worker co-operative movement expressed its anger at the current capitalist system by occupying factories, the owners of which had abandoned when profits declined sharply (or ceased to exist) in response to the new economic climate. The workers waged a protracted and emotionally draining battle in the courts, campaigning for the right to take over their factories and run them as co-operatives. They faced innumerable challenges to establish their co-operatives including hostility from existing factory owners and a legal system that protected the primacy of private ownership of property. Despite this resistance, the workers eventually won their legal battle and a range of worker co-operatives were formed throughout Argentina. The movement 
was based on worker solidarity and this principle was reflected in the equal pay policies adopted by most co-operatives. Many workers even felt the need to guard the factories 24/7 to prevent the owners reclaiming and disposing of the assets. The worker co-operative movement in Argentina is characterised by a 'bottom-up' approach to development, as opposed to being driven by socialist policies, an approach adopted by the Yugoslavian government in the 1970 .

\section{Why employee-owned firms are formed}

\section{Tax reasons, savings and concessions}

Employee ownership, particularly in the form of direct or trust share ownership, is often used as a mechanism to generate tax and/or organisational efficiencies. Pierce and Furo observe:

financial and tax incentives provided by the ESOP arrangement (consider that more tax breaks exist for an ESOP than for any other type of pension plan) have dominated management thinking and motivated companies to adopt employee-ownership systems. ${ }^{4}$

Pierce and Furo raise concerns that employee ownership based on the rationale of financial or tax efficiencies will not generate the same commitment from employees, particularly if opportunities for participation in management and governance are absent. ${ }^{5}$

\section{Case study 8.3 - United Airlines}

\section{An extended version of this case study can be found on the VLE.}

In July 1994, United Airlines (UA), which has now merged with Continental Airlines to form United Continental Holdings, publicly launched its Employee Stock Ownership Plan (ESOP). The ESOP purchased fifty-five per cent of the company's shares, making UA's 85,000 employees the company's largest shareholders and UA became, for a time, the largest employee-owned company in the world. In December 2002, with shares in the company only worth \$0.82, UA filed for Chapter 11 bankruptcy in the US, resulting in the biggest bankruptcy in American airline history and bringing an end to the company's brief flirtation with employee ownership.

\section{How the ESOP came about}

The eventual launch of the ESOP in 1994 was actually the fourth attempt to introduce employee ownership to UA. During the mid 1980s, the Air Line Pilots Association (ALPA), the union that represented the pilots in UA, mooted the possibility of employee ownership in response to a strike around that time.

The ESOP implemented in 1994 arose out of a need to restructure labour contracts in the face of economic turbulence in the airline industry. Southwest Airlines, with its disruptive new business model of high volume flights and low costs (replicated by airlines such as Ryanair and Easyjet), forced other airlines to adapt or face ruin. The management of UA saw a need to cut their labour 
costs, among other initiatives, to remain competitive in a rapidly evolving industry. Anticipating this loss in wages and benefits, a number of the more powerful unions in UA, particularly ALPA and the International Association of Machinists and Aerospace Workers (IAM), proposed to transfer some of the equity to the employees of the company. After negotiations with senior management, a deal was agreed in July 1994 and the ESOP was publicly announced. In exchange for a fifty-five per cent equity stake in the company, the unions agreed to wages and benefits concessions of $\$ 4.88 \mathrm{bn}$.

Source: C. Rosen, United Airlines, ESOPs, and Employee Ownership. Oakland: National Center for Employee Ownership, 2002. C. Mackin, United It Was Not. Cambridge: Ownership Associates, 2003.

\section{Organisational stability/sustainability}

Employee ownership provides a proven mechanism for ensuring organisational sustainability and stability. In a study of US firms with some form of employee ownership, Blair, Kruse, and Blasi found that employee-owned companies were much less likely to be converted to private organisations, and suggested that employee ownership was an important factor in preventing hostile takeovers. ${ }^{6}$

\section{Case study 8.4 - Voestalpine AG}

The largest employee-owned company by voting rights and market value in Austria, Voestalpine AG is a steel manufacturer and has operations in over sixty countries. Central to the stability and ongoing performance of the group (sales were almost $€ 11 \mathrm{bn}$ in 2010) is its commitment to employee share ownership. Thirteen per cent of the group's shares are held by 21,700 employees, totalling $22.4 \mathrm{~m}$ shares. Employees are the second largest shareholder and have a unique role in the governance of the company. Whilst the shares are held individually by the employees, the voting rights are bundled together, meaning the employee-owners vote as one. By holding more than ten per cent of the group's shares and voting as one body, Voestalpine's employees have the ability to block hostile takeovers of the group. Voestalpine AG refers to this form of employee ownership as 'strategic ownership'.

Source: Voestalpine AG. 'The basic principles of Employee Participation'. http://www.voestalpine.com/group/en/ group/employee-participation/grundsaetze-der-mitarbeiterbeteiligung.html, accessed 15 August 2011.

\section{Decline}

An employee-owned firm can be said to have declined - that is, ceased operating as an employeeowned business - in three ways:

1. Cessation of trading activity

2. Takeover by a conventional firm

3. Conversion to a conventional firm 
Various characteristics inherent to employee-owned firms, such as their structure and democratic nature, may contribute to their decline. Many of the arguments that follow relate to worker cooperatives, but where appropriate mention of other forms of employee ownership will be made.

\section{Degeneration}

There are two sides to the theory of degeneration:

Democratic degeneration:

according to this side, what starts out as a democratic firm (whether a worker co-operative or an employee-owned enterprise) will eventually become less democratic as a result of economic pressures/improvement in performance and the adoption of traditional organisational structures such as management hierarchies. ${ }^{7}$ The company may remain employee-owned in terms of its ownership structure and legal identity but, in fact, it is more similar to a conventional company. This problem is more likely to afflict larger employee-owned companies. In such scenarios, there is often conflict between managerial logic and governance institutions.

Conventional degeneration:

first proposed by the Webbs in the early twentieth century, this side proposes that worker co-operatives will eventually convert to a conventional form of enterprise. These 'associations of capitalists', as the Webbs referred to them, would eventually revert to an investor-owned firm by the increasing hiring of non-members. The argument is made that members tend to maximise their individual share of the surplus, therefore workers are less expensive to hire than new members. The rate of degeneration correlates with the amount of profit the firm generates: the more profit, the more likely the worker co-operative is to convert to a conventional firm.

\section{Case study 8.5 - Olympia Veneer co-operative}

Established in January 1921 with two hundred shares worth \$500 each, Olympia Veneer is one of the most successful worker co-operatives in US history in financial terms, and pioneered the development of a robust and profitable plywood co-operative sector in the northwest of America between the 1920 s and 1950 s. $^{8}$ The co-operative had around 120 members originally and swiftly established itself as a profitable business. It began hiring non-members in 1922, and this practice continued apace for the rest of the co-operative's existence. The company operated successfully for more than thirty years and was bought out in 1955. By the time it was sold, however, there were one thousand non-member workers and only sixty-nine members. Of those sixty-nine members, twenty-three realised an average return on their shares of $\$ 652,000 .{ }^{9}$ The degeneration of the company arose due to the rapid increase in the value of the shares over the lifetime of the cooperative. It simply became too expensive for prospective members to purchase shares in the company and so membership levels were gradually diluted. 
The Webbs also proposed that the worker co-operative structure had inherent weaknesses that would contribute to its economic decline (i.e. ceasing to trade):

- a lack of business administration skills;

- inward-looking;

- will not adopt new technologies if they threaten jobs. ${ }^{10}$

The Webbs' theory is supported by the work of Ben-Ner who proposes that worker co-operatives are an unstable form of enterprise. He argues that a worker co-operative would eventually degenerate into a capitalist company since members would seek to hire non-member workers rather replace 'expensive' members. Ben-Ner concludes that worker co-operatives will only survive in this form if they operate in marginal industries in which capitalist firms do not compete. ${ }^{11}$ Finally, Cornforth proposes that there are other factors that could contribute to the eventual degeneration of worker co-operatives, in addition to those proposed by the Webbs:

1. under capitalisation;

2. lack of management/business skills;

3. lack of discipline;

4. poor relationships between management and workers;

5. lack of political support;

6. top-down development. ${ }^{12}$

However the Webbs' rather pessimistic outlook on the performance of worker co-operatives (and assumption that members were capitalistic in their outlook) has been challenged and disproven by the empirical work of Jones, as well as by the continued success of Mondragón Corporation. ${ }^{13}$

The conventional degeneration thesis also applies to other forms of employee-owned firms, as the work of Pérotin and Robinson illustrates:

Employee-owned firms can be set up as conventional joint stock companies in which employees own the shares (though not all employees necessarily own shares) and may sell them outside. This is the rule for example in the US and in the majority of employee-owned firms that resulted from privatisation in Western as in Eastern Europe. This structure makes it possible for employees to accumulate some wealth as the value of the shares appreciates and makes the shares liquid. However, it also implies that employee ownership is potentially unstable. If the share value rises a lot, it may also become difficult for new employees to join the firm as coemployee-owners. Employee-owned firms structured in this way have been repeatedly observed to turn into conventional firms as the proportion of owners among employees dwindled over time and/or employee owners sold the business to a conventional owner. While this is not necessarily a problem if the employee acquisition of the firm was accidental, as it were, or resulted from a scheme with primarily distributional objectives, it is a potentially serious risk if employee ownership or industrial democracy is in itself an objective. ${ }^{14}$ 


\section{Stability and sustainability of worker co-operatives}

In light of the arguments discussing the apparent weaknesses of the employee-owned model of enterprise, it is worth drawing upon some empirical studies to see if these theories are correct. Survival figures for SMEs in the UK and across the world are low, especially in the first three years of an organisation's life. Empirical analysis conducted by Thomas and Cornforth found that worker co-operatives had a survival rate of sixty-six per cent for the years 1978-86 (a period of rapid growth for worker co-operatives in the UK); they found that this compared favourably with the survival rate (sixty per cent) of all small businesses for a similar time period. ${ }^{15}$

In a similar study, Estrin and Jones found that the degeneration thesis was incorrect from their analysis of French worker co-operatives. Their research found that French worker co-operatives were economically successful as well as stable, dispelling the hypothesis that they would eventually morph into a capitalist firm. ${ }^{16}$

\section{Lifecycle}

In this section, we examine employee-owned companies and their formation and decline in relation to the business cycle - that is, periods of economic expansion and recession. ${ }^{17}$ The traditional business cycle theory is that firms are more likely to be established in times of economic stability and more likely to decline in recessions. Employee-owned companies, on the other hand, have been predicted to form and decline counter-cyclically (that is, to form in periods of recession and degenerate into capitalist firms in periods of economic prosperity). Theoretical and empirical work by Pérotin and Miyazaki has revealed that part of this hypothesis is correct, that employee-owned firms are more likely to form in periods of economic recession than in times of economic stability. ${ }^{18}$ Reasons for such a response to the business cycle are based on the greater opportunities to convert ailing businesses to employee ownership, as well as the threat and high levels of incidence of unemployment. ${ }^{19}$ Staber, on the other hand, questions whether there is any link between employee ownership and the business cycle:

There is no compelling evidence for the argument that the founding and failure rates of worker cooperatives are systematically related to the business cycle. The empirical results of this study suggest that worker cooperatives are founded and survive independently of general economic conditions, as measured by unemployment and recession cycles. ${ }^{20}$

The response of employee-owned firms in relation to the decline phase of the business cycle is the same as for conventional enterprises, rather than being counter-cyclical. In times of recession, employee-owned firms, in particular worker co-operatives, are just as likely to decline as conventional companies.

Returning to an earlier point, that employee-owned firms are vastly outnumbered by conventional organisations at the formation phase, Pérotin found that:

Problems with firm creation, rather than dissolution, may explain the limited incidence of labor-managed firms even in countries where issues of structural viability have been resolved. ${ }^{21}$

Finally, Dow provides a theory as to why levels of formation greatly lag behind those of conventional organisations: 
But in a world where most firms are created in order to bring material benefits to their founders, LMFs (Labour Managed Firms) are clearly the underdogs. ${ }^{22}$

\section{Democracy and the lifecycle of worker co-operatives}

One of the first studies to explore the evolution of democracy in employee-owned firms was written by Meister in 1961. Echoing the assertions of the Webbs, Meister argues that there are four phases of a worker co-operative's lifecycle:

\section{Formation:}

direct democracy is central to the operations of the business. There is a lack of capital and the economic functions of the organisation are poorly developed.

2. Transition:

the co-operative begins to adopt more conventional organisational practices. Conflict arises between management and the democratic nature of the co-operative.

3. Establishment:

the co-operative has now accepted market values and traditional management hierarchy. Begins to hire more non-members and representative democracy emerges.

\section{Decline:}

management hierarchy assumes control of the co-operative. ${ }^{23}$

Meister's lifecycle is based on the degeneration thesis of worker co-operatives; that is, that these businesses will eventually succumb to market pressures and convert to the capitalist enterprise model.

To conclude, the degeneration thesis is overly pessimistic and has not been supported by empirical evidence. Therefore, we need a more accurate theory of the lifecycle of worker co-operatives. Batstone counters Meister's theoretical lifecycle by proposing an alternative process of worker co-operative development based on his empirical analysis of sixty French worker co-operatives. Batstone proposes that there are three distinct stages in a worker co-operative's lifecycle:

\section{Establishment:}

the co-operative will have few members (and almost all workers will be members) and a shortage of funds. Direct democracy will be the norm and there will be high levels of consensus amongst the members.

\section{Growth:}

the co-operative begins to adopt more traditional organisational elements such as management hierarchies and adherence to market forces. This stage is also characterised by a growth in the capital available to the co-operative and in the number of workers. The strength of professional management grows and democratic interests become secondary to the needs of the business.

\section{Maturity:}

this stage is characterised by a resurgence of the democratic process (representative rather than direct), a growth in membership, and renewed focus on the interests of labour (members) rather than capital or management. Unlike Meister's model, the co-operative does not degenerate into a capitalist firm but rather rediscovers the importance of the democratic nature of the business. ${ }^{24}$ 
The effects of increasing organisational complexity and the adoption of traditional hierarchies have long been scrutinised. In an empirical study of Canadian worker co-operatives, Hunt found that the division of labour (task specialisation) had no negative effects on the democratic organisation of three worker co-operatives; in fact, he asserted that task specialisation strengthened workers' control over work activities. This was due to the creation of horizontal hierarchies that promoted greater autonomy amongst small groups of workers. Hunt suggested that the design of work in worker co-operatives evolves as the business progresses through its lifecycle. ${ }^{25}$ Worker cooperatives begin as collective decision-making entities with job rotation, and equality of pay and benefits. As economic factors become more prominent, task specialisation occurs and collective decision-making becomes less effective, precipitating a move toward representative democracy and semi-autonomous work groups.

To sum up, the evidence suggests that democracy does not decline over the lifecycle of the worker co-operative but rather evolves to suit the structure of the business as it progresses through its lifecycle. ${ }^{26}$

\section{Summary of learning}

This chapter has argued that:

- The rationale and mechanisms for establishing employee-owned companies differ according to the form of employee ownership.

- The economic, social, and political environments are relevant to understanding the formation and decline of employee-owned companies.

- Employee-owned firms face specific problems at the formation stage compared with other forms of enterprise.

- Employee-owned firms do not possess certain traits that result in their inevitable failure as businesses.

- Democratic structures and worker control do not necessarily diminish as a result of adopting more conventional organisational characteristics.

\section{Essay/discussion questions}

- Why are there so few employee-owned firms in the UK?

- What are the barriers to the formation of and conversion to employee ownership?

- Discuss the theoretical explanations for the small number of employee-owned firms?

- Are employee-owned firms destined to fail or degenerate into conventional companies?

- What factors are associated with the conversion of employee-owned firms into conventional companies?

- Do you agree with the theory that management and organisational issues supersede those of democracy and commitment to employee ownership? 
Ohio Employee Ownership Center -

http://oeockent.org/index.php/component/content/article/136.

Co-operative Development Scotland - http://www.cdscotland.co.uk/.

Baxi Partnership - http://www.baxipartnership.co.uk/.

The Co-operative Enterprise Hub - http://www.co-operative.coop/enterprisehub/.

Ownership Associates - http://www.ownershipassociates.com/index.shtm.

Foundation for Enterprise Development - http://www.fed.org/.

Co-operative Business Consultants - http://www.cbc.coop/.

\section{Endnotes}

1. Department for Business, Innovation and Skills, 'Small and Medium-sized Enterprise Statistics for the UK and Regions 2009' 13 October 2010. http://stats.bis.gov.uk/ed/sme/, accessed 12 August 2011.

2. G. Dow, Governing the Firm: Workers Control in Theory and Practice (Cambridge: Cambridge University Press, 2003$),$ p. 213.

3. R. Paton (ed), Reluctant Entrepreneurs (Milton Keynes: Open University Press, 1989), p. 16.

4. J. L. Pierce and C. Furo, 'Employee Ownership: Implications for Management' Organizational Dynamics 18 (1990): 32-43. See p. 35.

5. Pierce and Furo, 'Employee Ownership: Implications for Management', p. 41.

6. M. Blair, D. Kruse, and J. Blasi, 'Is Employee Ownership an Unstable Form? Or a Stabilizing Force?' in T. Kochan and M. Blair (eds), The New Relationship: Human Capital in the American Corporation (Washington: The Brookings Institution, 2000), p. 281.

7. 'Management hierarchies' here refers to the establishment of managerial positions based on power rather than function. This can be thought of as the erosion of worker participation in decision-making and the clustering of organisational power in fewer hands. There is no issue with the concept and practicalities of management in employee-owned businesses, rather the abuse of such positions and a lack of accountability.

8. Plywood Pioneers Association, 'Olympia Veneer Company' Plywood in Retrospect No. 7. (Tacoma: Plywood Pioneers Association, 1969), p. 3.

9. S. Bowles, Microeconomics: Behavior, Institutions, and Evolution (Princeton: Princeton University Press, 2006), p. 331.

10. S. Webb and B. Webb, Consumers Co-operative Movement (Published by the authors), 1921.

11. A. Ben-Ner, 'On the Stability of the Cooperative Type of Organization' Journal of Comparative Economics 8 (1984): 247-60. See p. 258.

12. C. Cornforth, 'Some Factors Affecting the Success or Failure of Worker Co-operatives: A Review of Empirical Research in the United Kingdom' Economic and Industrial Democracy 4 (1983): 163-90. See p. 174. Most of these factors might apply to any form of enterprise.

13. D. C. Jones, 'British Producer Co-operatives' in K. Coates (ed). The New Worker Co-operatives (Nottingham: Spokesman Books, 1976) and S. Estrin and D. C. Jones, 'The Viability of Employee-Owned Firms: Evidence from France' Industrial and Labor Relations Review 45 (1992): 323-38.

14. V. Pérotin and A. Robinson, 'Employee Participation in Profit and Ownership: A Review of the Issues and Evidence' Paper prepared for the European Parliament, December 2002, p. 12. This is particularly acute in employee-owned companies where shares are freely tradable (as discussed in chapter 6); see the case study on National Freight Corporation on the VLE.

15. A. Thomas and C. Cornforth, 'The Survival and Growth of Worker Co-operatives: A Comparison with Small Businesses' International Small Business Journal 8 (1989): 34-50. See p. 45.

16. Estrin and Jones, 'The Viability of Employee-Owned Firms: Evidence from France'.

17. By economic, we are referring to the state of local, national and international economies rather than the economic performance of an individual firm or industry.

18. V. Pérotin, 'Entry, Exit, and the Business Cycle: Are Cooperatives Different?' Journal of Comparative Economics 34 (2006): 295316; H. Miyazaki, 'On Success and Dissolution of the Labor-managed Firm in the Capitalist Economy' Journal of Political Economy 92 (1984): 909-31.

19. It is this seemingly inherent ability to form, survive and prosper during periods of economic turbulence that raises the issue of political support for employee ownership as 'the greater firm survival and employment stability among employee ownership firms indicate that employee ownership may have an important role to play in increasing job and income security, and decreasing levels of unemployment.' R. Park, D. Kruse, and J. Sesil, 'Does Employee Ownership Enhance Firm Survival?' Advances in the Economic 
Analysis of Participatory and Labor-Managed Firms 8 (2004): 3-33. See p. 31.

20. U. Staber, 'Worker Cooperatives and the Business Cycle: Are Cooperatives the Answer to Unemployment?' American Journal of Economics and Sociology 52 (1993): 129-43. See p. 138.

21. Pérotin, 'Entry, Exit, and the Business Cycle: Are Cooperatives Different?' p. 296.

22. G. Dow, Governing the Firm: Workers Control in Theory and Practice, p. 212.

23. A. Meister, 'Democratie et participation dans les associations volontaires' Sociologie du Travail 3 (1961): 236-52.

24. E. Batstone, 'Organization and Orientation: A Life Cycle Model of French Co-operatives' Economic and Industrial Democracy 4 (1983): 139-61. See pp. 150-2.

25. G. C. Hunt, 'Division of Labour, Life Cycle and Democracy in Worker Co-operatives' Economic and Industrial Democracy 13 (1992): 9-43. See p. 38.

26. This refers back to an earlier point about how co-operatives need to balance business success with member involvement (chapter 3). 


\section{Democratic enterprise: the invisible giant?}

What could be important in this

co-operative initiative is not what is

accomplished but what it is intended

to do.'

Don José María Arizmendiarrieta

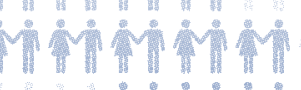

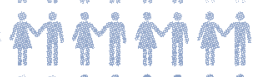

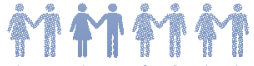

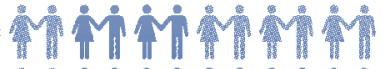

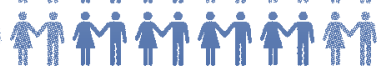

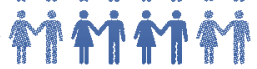

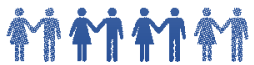

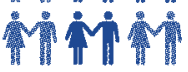

in

in

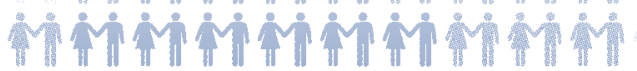

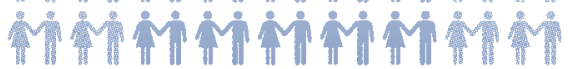

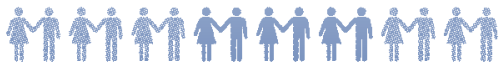

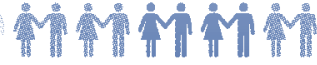

MTMM Min

Mำin

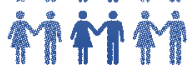

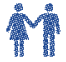

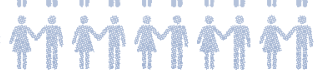

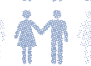

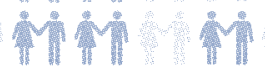

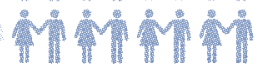

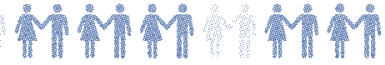
Mำำ

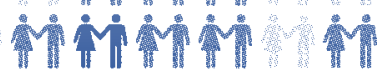

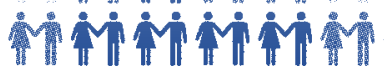

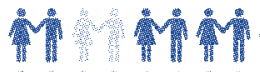




\section{Democratic enterprise: the invisible giant?}

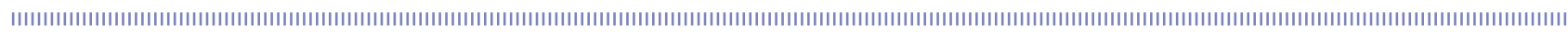

\section{Learning objectives}

This chapter begins with an overview of global and national statistics relating to co-operatives and employee-owned businesses. It then considers the social, political, and economic environments in which these enterprises currently operate, and analyses the factors that promote or inhibit the growth of this sector. The chapter concludes by outlining a 'roadmap' for the future development of the democratic enterprise movement. By the end of this chapter you will be able to:

- understand the prevalence of co-operatives and employee-ownership at local, national, and international levels;

- appraise the environment in which democratic enterprises currently operate;

- analyse the factors that promote or inhibit growth of the democratic enterprise sector;

- explain the steps needed to develop the sector at local, national, and international levels.

\section{The key arguments that will be developed in this chapter are:}

Co-operative and employee-owned businesses make a significant contribution to the world economy.

Globalisation presents both threats and opportunities for democratic enterprise.

There is an increasing public appetite for democratic enterprise development which favours a ground-up rather than top-down approach.

Action and education are needed to ensure society benefits from a vibrant democratic enterprise sector in the future.

\section{Democratic enterprise today}

\section{Co-operatives}

The co-operative model of enterprise plays a much bigger role in the world's economy than is generally recognised. Internationally, there are over one billion people who are members of co-operatives. In 1994, the United Nations estimated that the livelihood of nearly three billion people, or half of the world's population, was made secure by co-operative enterprises. 


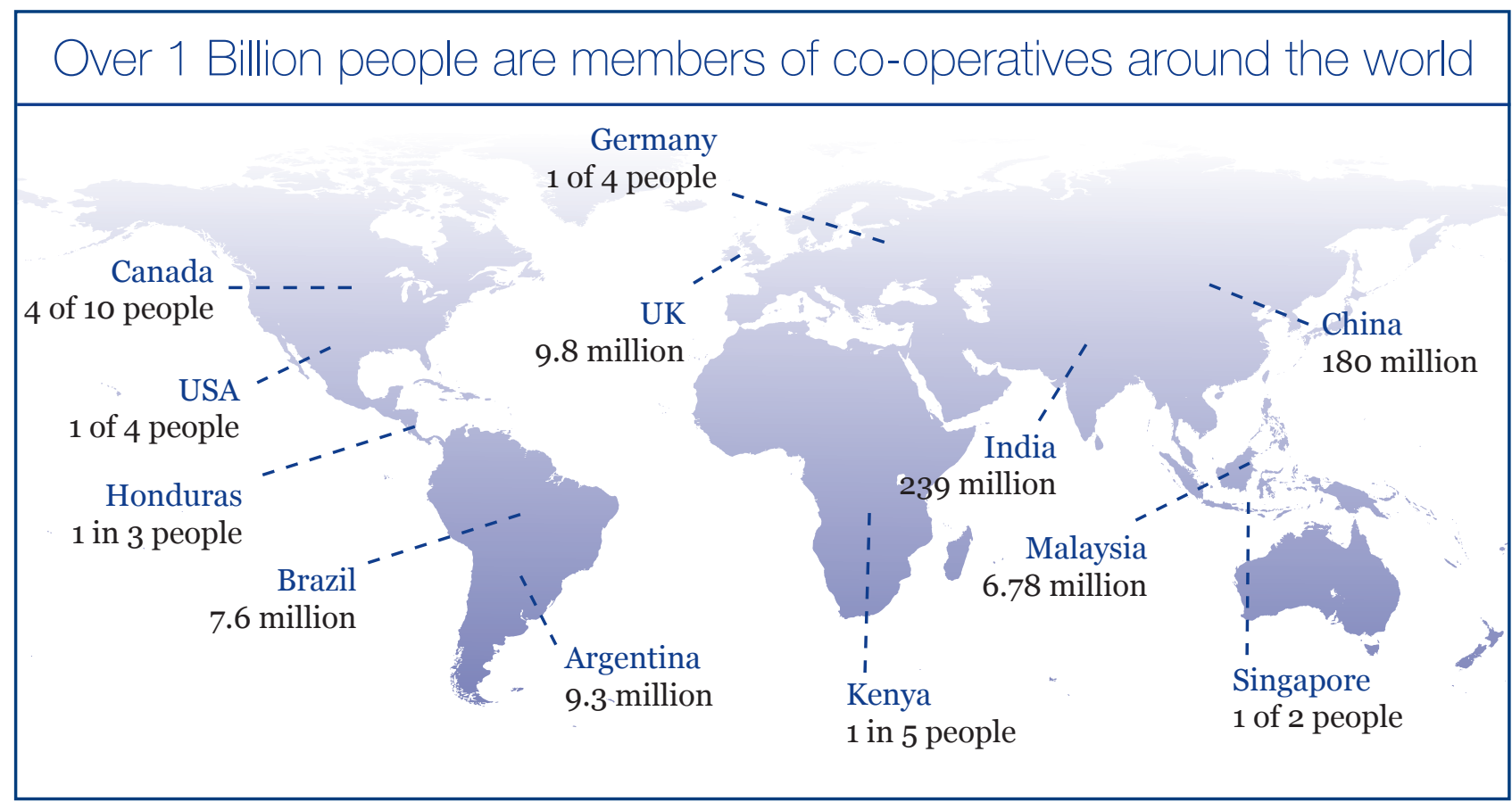

Source: 'Statistical Information on the Co-operative Movement' ICA. http://www.ica.coop/coop/statistics.html, accessed 29 September 2011.

\section{The Global300 project}

The Global30o project was initiated to capture the size of the co-operative movement globally, measured in terms of turnover. Analysis of the largest three hundred co-operatives and mutuals reveals that turnover was around $\$ 1.6$ trillion at the end of 2008, equivalent to the ninth largest economy in the world. ${ }^{1}$ 
Figure 9-Global3oo project

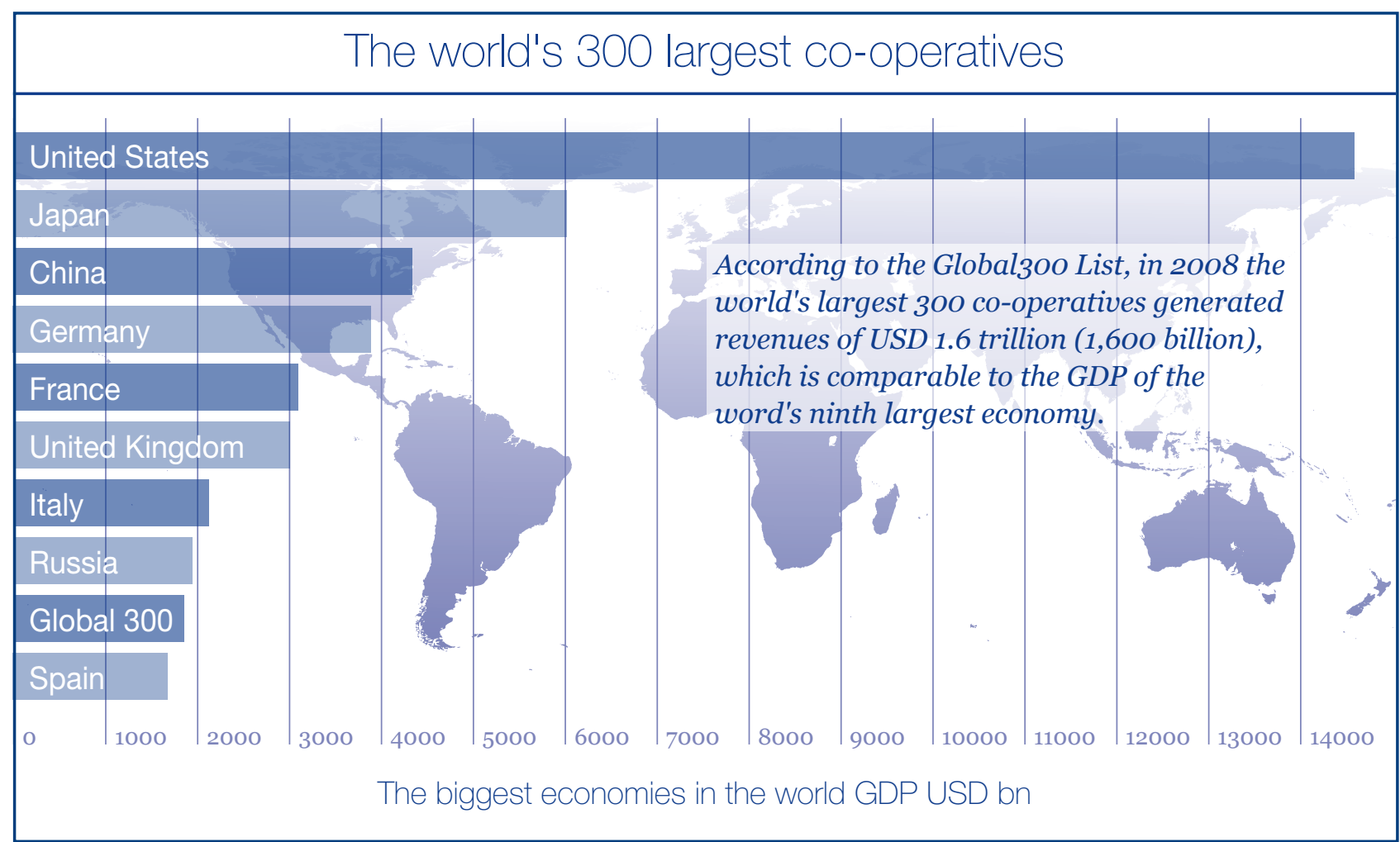

Source: International Co-operative Alliance. Global 300: 2010 Report (Geneva: International Co-operative Alliance), 20o1. p. 2.

\section{The UK co-operative sector}

The latest figures released by Co-operatives UK show that almost one in five citizens in Britain are members of a co-operative. In economic terms the UK co-operative sector has performed strongly in recent years. There has been a 21 per cent growth in turnover for the co-operative sector between 2008 and 2010. This has been coupled with an 18 per cent growth in membership, and a 15.1 per cent growth in the number of co-operatives.

Table 18-Summary of co-operative sector in UK

\begin{tabular}{|l|l|}
\hline No. of co-operative businesses in the UK: & 5,450 \\
\hline No. of members: & $12.8 \mathrm{~m}$ \\
\hline Turnover of co-operatives: & $£ 32.2 \mathrm{bn}$ \\
\hline No. of people employed by co-operatives: & 236,000 \\
\hline
\end{tabular}




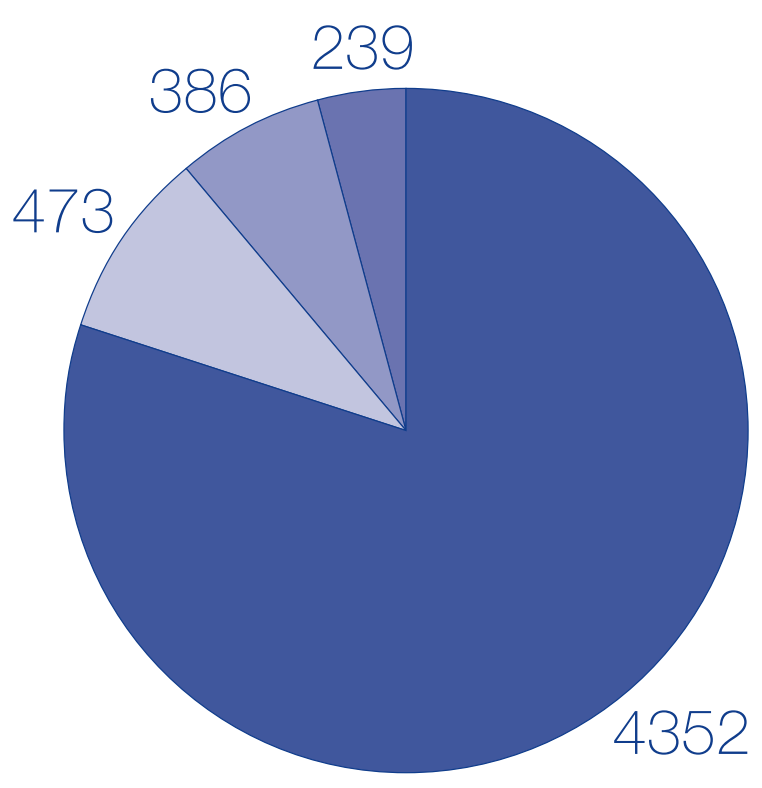

England

Scotland

Wales

Northern Ireland

Source: Co-operatives UK. The UK co-operative economy 2011: Britain's return to co-operation (Manchester: Co-operatives UK, 2011), p. 23.

Figure 11-Percentage growth of the UK movement

\% Growth of the UK Co-operative Movement

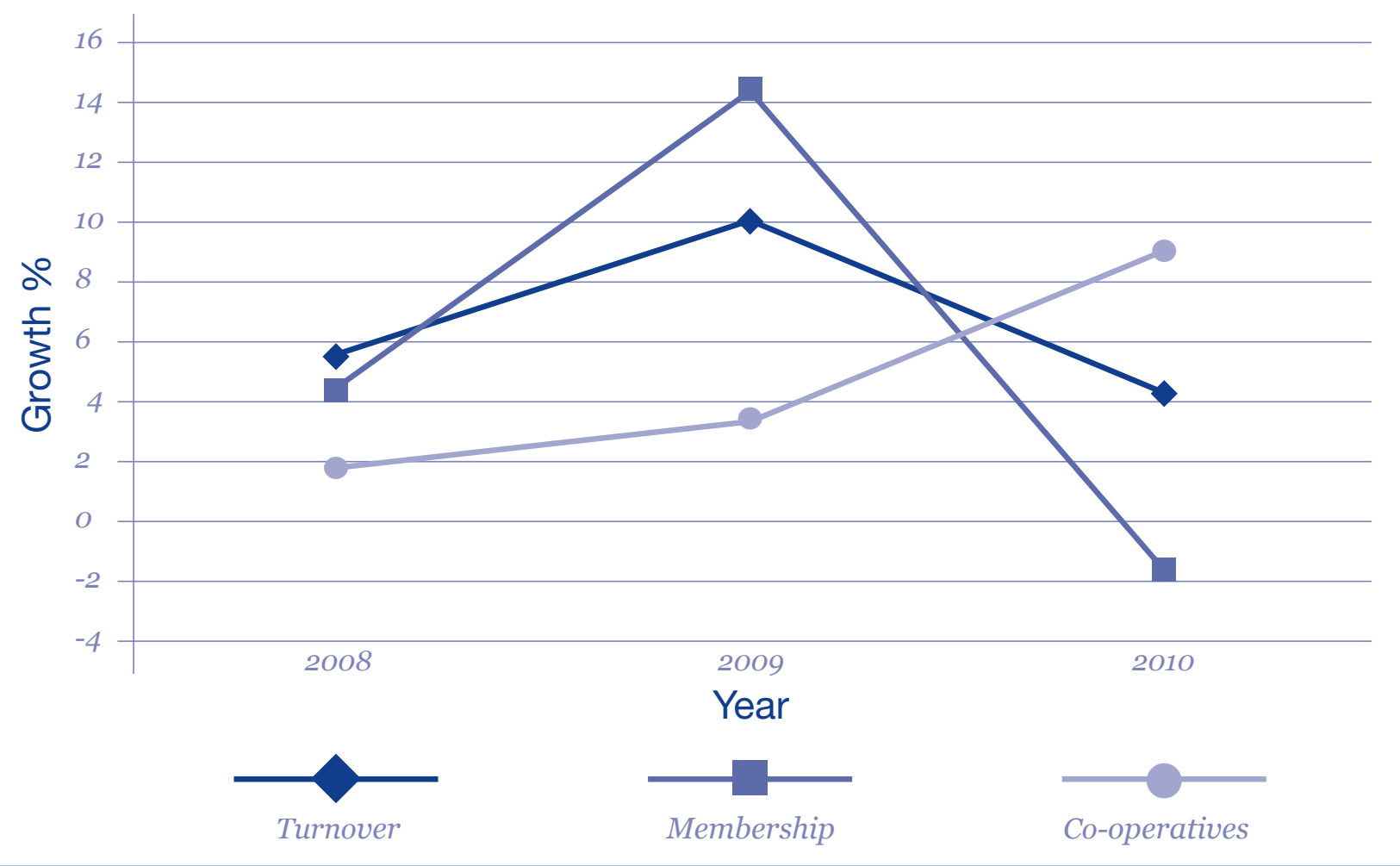

Source: Co-operatives UK. The UK Co-operative Economy 2011: Britain's Return to Co-operation (Manchester: Co-operatives UK, 2011), pp. 2O-2. 


\section{Worker co-operatives}

The worker co-operative sector in the UK is quite small, particularly in comparison to other European countries. It is estimated that there are around 450 worker co-operatives in the UK, of which perhaps forty to fifty are based in Scotland. ${ }^{2}$ The number of members of worker cooperatives has risen from 2,048 members in 2009 to 5,234 members in $2010 .^{3}$

By comparison, the Italian region of Emilia-Romagna is home to over 8,000 worker co-operatives operating in industries as diverse as ceramics, construction, fashion, social care and cheese production. The co-operatives survive and prosper through the formation of federations, the largest being Legacoop with one million members and turnover of almost $\$ 8 \mathrm{bn} .{ }^{4}$ A significant portion of these 8,00o worker co-operatives are known as 'social co-operatives', including some that are mainly focused on providing jobs for disadvantaged people. ${ }^{5}$

The worker co-operative sector in the US (known as 'democratic workplaces') is smaller, in part due to the proliferation of another form of employee ownership, the ESOP. It is estimated that there are over 300 worker co-operatives in the US, employing 3,500 people and generating over $\$ 400 \mathrm{~m}$ in revenue. ${ }^{6}$ The majority of these businesses are SMEs and operate in the retail and service sectors.

\section{Employee ownership}

According to estimates from 2010, the employee-owned sector in the UK is worth £25bn in revenue, accounting for two per cent of GDP. ${ }^{7}$ The Employee Ownership Association estimates that there are over one hundred companies with majority or significant employee ownership. One of the main reasons employee ownership is under-developed in the UK is the lack of understanding of the model amongst key support institutions such as banks, financial and legal advisors, and policy makers.

The employee ownership sector in the US is significantly better monitored and analysed than its UK counterpart. The National Center for Employee Ownership (NCEO) is a private, nonprofit membership and research organisation that serves as the leading source of information on employee ownership in the US. The ideological beliefs underlying employee ownership in the US differ from those in other countries; industrial democracy is subordinate to the need to involve workers in capitalism through share ownership. This belief reflects the historical origins of employee ownership in the country, when the major national companies of the early twentieth century (such as Proctor and Gamble, and Ford) offered employees shares in the company at a discount.Table 19 summarises the volume and value of the various employee ownership share plans in the US. 


\begin{tabular}{|l|l|l|l|}
\hline Type of Plan & $\begin{array}{l}\text { Number of } \\
\text { Plans (as of } \\
\text { early 2010) }\end{array}$ & $\begin{array}{l}\text { Number of } \\
\text { Participants } \\
\text { (as of the } \\
\text { end of 2008) }\end{array}$ & $\begin{array}{l}\text { Value of Plan } \\
\text { Assets (as of the } \\
\text { end of 2007) }\end{array}$ \\
\hline $\begin{array}{l}\text { ESOPs, stock bonus plans, \& profit sharing } \\
\text { plans primarily invested in employer stock }\end{array}$ & 11,300 & 13.6 million & \$901 billion \\
\hline $\begin{array}{l}401(k) \text { plans primarily invested in } \\
\text { company stock }\end{array}$ & 800 & 5 million & \$200 billion \\
\hline Broad-based individual equity plans & 3,000 & 10 million & $\begin{array}{l}\text { (\$5 billion to } \$ 10 \\
\text { billion in 2008, } \\
\text { S\&P 1500 only) }\end{array}$ \\
\hline Stock purchase plans & 4,000 & 11 million & $\begin{array}{l}\text { (not realistic to } \\
\text { estimate) }\end{array}$ \\
\hline
\end{tabular}

Source: A Statistical Profile of Employee Ownership, National Center for Employee Ownership, Updated April 2011, www.nceo.org.

Sociedades laborales is the Spanish term for an employee-owned company. Figures from the second quarter of 2010 highlight the scale and impact of employee-owned companies in Spain: 15,303 employee-owned companies; 87,651 workers; estimated turnover of 16 billion euros (in 2007). ${ }^{8}$

In Spain a company is recognised as employee-owned if the majority of the voting rights are held by permanent contract workers. There are also provisions in place to prevent large inequality amongst employee shareholdings (one employee cannot hold more than one third of the voting rights). ${ }^{9}$ CONFESAL is the umbrella body of Spain's employee ownership sector and has seventeen members, one for each of the autonomous regions in the country. Political support for employee ownership is quite strong, with specific legislation mandating government support of participation in the property of the enterprise and a requirement 'to facilitate access by workers to ownership of the means of production'. ${ }^{10}$

Employee ownership is not just confined to the three countries mentioned above. Across Europe, broad-based financial participation schemes are a feature of most public and large private organisations. Since the late 1990s, the number of companies and employees participating in share schemes and profit sharing rose sharply. While such a development is to be welcomed, there remains much to do to promote and develop employee ownership in Europe. ${ }^{11}$ 


\section{The role of democratic enterprise in tackling pressing issues}

We have analysed the current incidence of democratic enterprises globally but what role (if any) can they play in tackling some of the most pressing issues facing society today?

\section{Globalisation}

Globalisation in the economic realm presents both threats and opportunities for democratic enterprises. Co-operatives and employee-owned businesses must keep pace with their economic competitors, who increasingly seek to transfer operations and capital offshore in a bid to minimise costs and maximise profits. This creates real pressure on democratic enterprises to follow suit or else develop alternative strategies.

Democratic enterprises can play a dual role in relation to globalisation: ${ }^{12}$

1. They can accept globalisation and use it as a mechanism to achieve their social and economic objectives. The Mondragón co-operatives, for example, have embraced globalisation and have factories throughout the world, some of which are in rapidly developing nations. ${ }^{13}$

2. They can limit the (negative) effects of globalisation by placing emphasis back on local communities. Examples include the role of co-operatives in the Fairtrade movement, micro finance and worker take-overs.

\section{Reflection - The current Industrial Revolution}

In light of the increasing industrialisation of developing countries (China, India, Brazil, and Indonesia for example), do you think there are opportunities for the democratic model of enterprise to help alleviate the problems industrialisation inevitably brings? What would be the impact of increased numbers of democratic enterprises in rapidly developing industrialised countries?

\section{Growing income inequality}

Income inequality is a worldwide phenomenon that receives considerable attention in the UK and other developed countries. Wilkinson and Pickett analysed the growing trend of income inequality in the UK from 1979 to 2006. These authors note that income inequality is linked with other inequalities, notably in access to education and social mobility. Reducing income inequality to create a fairer society is a complex challenge and it would be wrong to think that democratic enterprises provide a comprehensive solution. However, the collective sharing of rewards and the greater propensity of co-operatives and employee-owned businesses to keep money in the local economy mean that these enterprises can help to tackle the problem. 


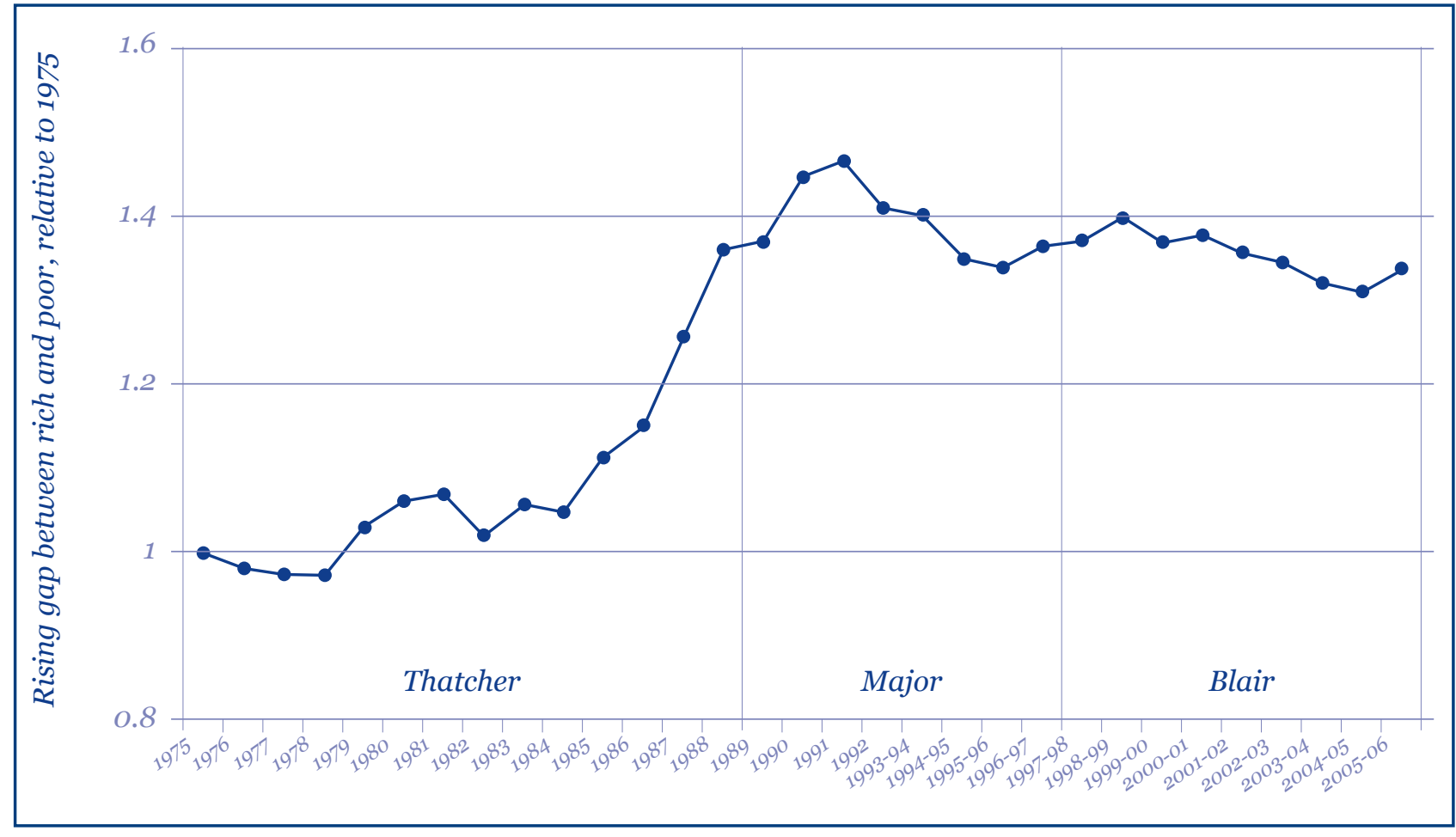

Source: Wilkinson \& Pickett. The Spirit Level (2009) www.equalitytrust.org.uk

\section{Big Society in the UK}

The Big Society initiative developed by the coalition government in the UK aims to help people 'to come together to improve their own lives. It's about putting more power in people's hands a massive transfer of power from Whitehall to local communities. ${ }^{14}$ The Big Society initiative has five main tenets:

1. Give communities more power over the planning process and the right to bid to take over public services as well as rescue local facilities or services that are threatened with closure.

2. Encourage volunteering.

3. Transfer power from central government to local government.

4. Support for mutuals, charities, co-operatives and social enterprises.

5. Publish government data. ${ }^{15}$

Since the manifesto was launched in June 2010, the UK co-operative, mutual, and employee ownership sectors have vigorously debated the opportunities and threats that the Big Society presents. Those in favour of the initiative have highlighted that it is a once-in-a-generation opportunity to gain favourable political support, which is a vital condition if the sectors are to grow. However, there are others who are wary of supporting the Big Society initiative, particularly within the co-operative movement. ${ }^{16}$ Concerns include the argument that the Big Society is just a smokescreen for cuts in government spending. There are also fears that Big Society is privatisation of state organisations and assets. Foremost among the concerns of the co-operative movement is the risk of failure that is attached to this initiative, which can damage the public perception of democratic models of enterprise. 
There is still a lack of collective response from the co-operative movement on the issue of Big Society, although efforts have been made to form organisations that can support the initiative. The Mutuals Information Service (MIS) was set up in 2010 to provide information and guidance for public sector organisations wishing to become mutuals. A partnership involving Co-operatives UK and the Employee Ownership Association, the MIS has, to date (October 2011), received over two hundred enquiries from groups planning to exercise their 'Right to Provide' from a wide variety of services within the public sector.

\section{Public support for democratic enterprise}

Owing to the economic downturn, there is growing public support for more democratic forms of organisation. Graphs below show that trust in business institutions is low and people are questioning the benefits of making shareholder value the sole driver of business activity. There are expectations that business should do more to invest in society. According to one survey, co-operatives are regarded as more trustworthy than the traditional PLC.

Figure 13-Trust in institutions 2008-2011

Trust in Institutions: 2008-2011

In US, 2011 decline mirrors 2008-2009 drop Only country to see across-the-board fall

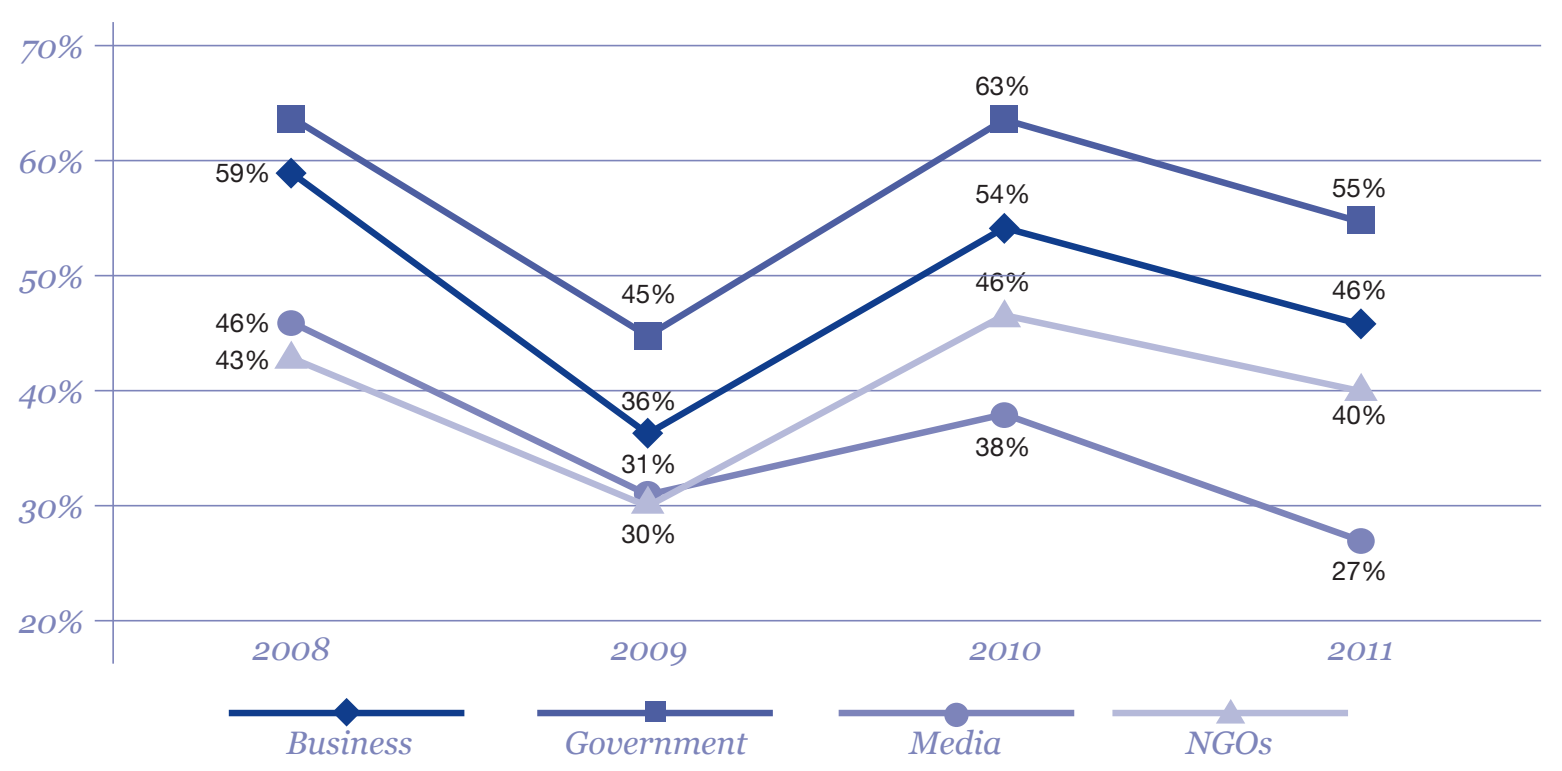

Responses 6-9 on 1-9 scale; 9 = highest, Informed publics ages 25-64 


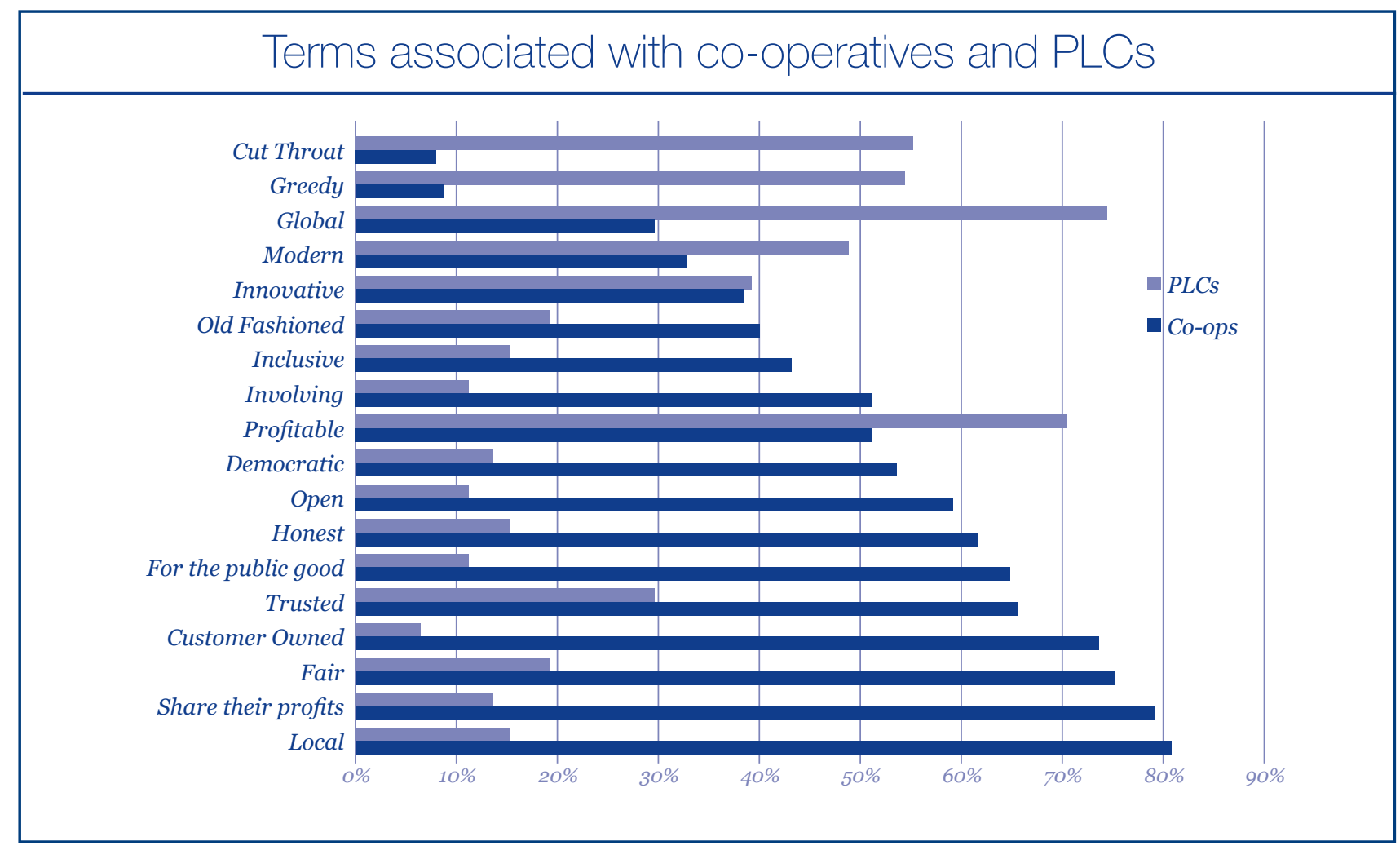

Source: G. Simon and E. Mayo, Good business? Public perceptions of co-operatives (Manchester: Co-operatives UK, 2O1O), p. 6.

The right social conditions for the development and growth of democratic enterprises exist as we enter the second decade of the twenty-first century. Wilkinson and Pickett explain:

1. People are questioning how there are increasing social problems when we are so well off materially.

2. Consumerism and materialism run counter to our values even though we still manage to get caught up in them.

3. People understand that inequality is divisive and socially corrosive. ${ }^{17}$

The major UK democratic enterprise development bodies are dealing with record levels of enquiries from the public and entrepreneurs. In 2010-11 Co-operative Development Scotland received 245 enquiries for advice and specialist support, representing a 350 per cent increase compared with the figures from the previous two years. Similarly, the Wales Co-operative Centre supported 202 co-operatives and social enterprises during 2010, and the Employee Ownership Association has recorded a boost in the number of new members. 


\section{Factors that affect the development of democratic enterprises}

Although there are differences between co-operatives and employee-owned businesses, both forms of democratic enterprise face some common challenges when it comes to growth. A report by the All Party Parliamentary Group on Employee Ownership in May 2008 highlighted some of the barriers to the development of the employee ownership sector in the UK:

- a shortage of data on the extent of the sector and its performance;

- lack of awareness and information about the sector among business owners, advisers, financial institutions, and public sector policy makers;

- unnecessarily restrictive tax rules affecting the sector;

- a relative lack of appropriate finance;

- inadequate government appreciation of and support for the sector;

- inadequate recognition in public purchasing procedures of potential value for money advantages offered by co-owned sector providers. ${ }^{18}$

\section{Issues to consider}

\section{Social factors}

\section{Social capital}

Democratic enterprises are reliant on an intangible resource known as social capital in order to support the development and legitimise the purpose of those enterprises. Social capital is a term that 'describes the pattern and intensity of networks among people and the shared values which arise from those networks'. ${ }^{19}$ There are different layers of social capital, known as bonding, bridging and linking. Without a 'well' of social capital to draw on, democratic enterprises will struggle to become established, and subsequently develop, in certain communities.

\section{Education}

There is interest in learning about co-operatives at primary and secondary level, as evidenced by the growth in the number of co-operative trust schools in England. ${ }^{20}$ In higher education, however, opportunities to learn about democratic models of enterprise are limited. The majority of economic research focuses on the investor-owned firm and the majority of teaching in business schools also concerns the investor-owned firm. Democratic enterprises rarely feature in undergraduate economics or business management textbooks. A study by Hill in 2000 revealed that only nine of the nineteen introductory economics textbooks that he analysed mentioned cooperative enterprises, and only one had more than a page on them. ${ }^{21}$ Hill's study was corroborated by Kalmi in 2007. ${ }^{22}$ It is important that students of all ages, who will form the next generation of entrepreneurs, are afforded the opportunity to learn about alternative models of enterprise. 


\section{Economic factors}

Financial resources

Reports, studies, and anecdotal evidence point to the lack of financial resources, particularly startup capital, available to democratic enterprises. This constraint affects the formation of democratic enterprises more than investor-owned enterprises.

Density

An economic ecosystem is characterised by the presence and density of certain types of organisation. Low density of democratic enterprises in an economy will tend to inhibit the rate of new formation.

\section{Support structures}

An appropriate support framework is central to the development of the few successful, large-scale democratic enterprises sectors in the world (Mondragón in Spain, Emilia-Romagna in Italy). Elements include tailored financial provision, facilitating legislation, and development agencies with appropriate resources. The provision of these support services is more the onus of the co-operatives themselves rather than being dependent on an external agency. ${ }^{23}$

\section{Political factors}

Knowledge and information

Although all three major political parties in the UK declared support for co-operative and mutual models of enterprise in the general election of 2010, there is a need to improve the knowledge of these models among policy makers.

\section{Research}

The UK needs institutional structures to promote research about co-operatives and employeeownership, similar to those found in Europe and the US. ${ }^{24}$

Supportive legislation and taxation

In the UK, companies are encouraged to distribute shares amongst employees through attractive tax breaks and facilitative legislation (most notably Share Incentive Plans). Levels of employee ownership in the US would not be where they are today without the support of the tax efficient ESOP legislation. Finally, worker co-operatives in Spain, Italy and France have flourished as a result of legislation that facilitates their development. ${ }^{25}$ 


\section{Where to now?}

A report commissioned by Co-operatives UK in 2010 sought to provide a 'roadmap' for how the UK movement could develop and grow in the next decade. The report outlined three key steps:

- UK co-operatives need to act more like a movement, particularly in response to the present socio-economic climate.

- The movement should shift its focus from co-operative 'form' to co-operative 'values', again to reflect the pressing concerns in the UK such as environmental damage and social corrosion.

- There needs to be a new model for financing co-operative creation and growth. ${ }^{26}$

There are some avenues that seem more promising than others:

- Energy supply and renewable energy generation are becoming areas of growth for consumer co-operatives, as evidenced by the number of recent start-ups. ${ }^{27}$

- Business succession offers good potential for the creation of employee-owned businesses.

- The financial crisis has created opportunities for more credit unions, co-operative banks and mutual financial providers. This is evidenced by the support for the campaign to re-mutualise the former Northern Rock building society and the preferred bidder status awarded to The Cooperative Bank in the sale of Lloyds TSB branches.

\section{SEMINAR EXERCISE - Action planning}

Materials to support this exercise can be found on the VLE

1. Divide the students into a number of groups depending on class size. It is not important how many members there are in each group but try to keep them evenly spread. Make sure each group has enough flipchart paper, markers and post-it notes.

2. Explain the scenario and assign a topic to each group.

3. Ask each group to identify key factors and actors related to each topic. Give the participants around 10 minutes to do this.

4. Now it is time for the action planning segment of the exercise: ask each group to develop a set of actions that each actor could take to contribute to the development of democratic enterprises.

5. Get each group to present their findings to the class as a whole and conduct the discussion element of the exercise. 


\section{Summary of learning}

This chapter has argued that:

- Co-operatives and employee-owned businesses play a significant role in societies and economies around the world.

- The democratic enterprise sector in the UK is under-developed compared with the situation in some other countries and will remain so until more favourable regulatory frameworks and policies are in place.

- There are social, economic, and political issues that must be addressed for the movement to develop and grow.

- Renewable energy and financial services are among the most promising growth areas for democratic enterprise.

\section{Essay/discussion questions}

- Assess the current status of democratic enterprises in your community. How many are there? Were you aware of their existence before conducting this research? If not, what does that say about education policy?

- How might a case be made to government for support (financial and legislative) for democratic enterprises?

\section{Useful resources}

Big Society Network - http://thebigsociety.co.uk/.

Beyond Grey Pinstripes - http://www.beyondgreypinstripes.org/.

People and Planet - http://peopleandplanet.org/.

Co-operative Global News Hub - http://www.thenews.coop/.

Co-operatives UK 2012 - http://www.uk.coop/2012 . 
1. The assertion that the turnover of the top 300 co-operative enterprises is equivalent to the tenth largest economy by GDP is not meant to be taken literally; GDP and turnover are not comparable figures. The purpose of the Global300 project is to highlight the scale of co-operative economic activity around the world not act as a direct comparison with the GDP levels of countries.

2. J. Birchall, People-centred Businesses: Co-operatives, Mutuals and the Idea of Membership (London: Palgrave MacMillan, 2010), p. 175.

3. The UK Co-operative Economy 2011: Britain's Return to Co-operation can be accessed at http://www.uk.coop/resources.

4. Birchall, People-centred Businesses: Co-operatives, Mutuals and the Idea of Membership , p. 174.

5. M. Hancock, The Cooperative District of Imola: Forging the High Road to Globalization. Progress Report, Research Project on the Cooperative District of Imola, Prepared for MUEC, 2004-5, p. 3.

6. US Federation of Worker Cooperatives, 'About Worker Cooperatives'. http://www.usworker.coop/aboutworkercoops, accessed 25 June 2011.

7. Employee Ownership Association (EOA), 'About Employee Ownership'. http://www.employeeownership.co.uk/employeeownership/about-employee-ownership/, accessed 7 May 2011.

8. Hancock, The Cooperative District of Imola: Forging the High Road to Globalization, p. 5. Note that these figures exclude the Mondragón co-operatives.

9. M. Millana, Exercising Employee Shareholders' Rights in Employee-owned Companies: Sociedades laborales. Presentation to the Spanish Business Confederation of Employee-owned Companies, Rome, 16 September 2010, p. 7.

10. Article 129-2 of the 1978 Spanish Constitution.

11. For a detailed analysis of employee financial participation (EFP) in the European Union (EU), The PEPPER IV report (available at www.efesonline.org) is an excellent resource. The report contains statistics and analysis on the availability of EFP across Europe, as well as an overview of employee ownership from a legal, fiscal and governance perspective for 29 individual European countries.

12. R. Ridley-Duff and M. Bull, Understanding Social Enterprise: Theory \& Practice (London: Sage, 2011$)$, p. 103.

13. These factories are not co-operatively run, which poses the question whether the Mondragón co-operatives are beginning to resemble conventional firms or whether they are strengthening the movement by embracing internationalisation.

14. Cabinet Office, 'Big Society'. http://www.cabinetoffice.gov.uk/big-society, accessed 29 September 2011.

15. 'Building the Big Society' (Westminster: Cabinet Office, 2010).

16. This is mainly as a result of a previous UK government initiative in the late 1970s, where the public perception of co-operatives was tarnished as a result of businesses failing after being converted to co-operatives.

17. R. Wilkinson and K. Pickett, The Spirit Level: Why Equality is Better for Everyone (London: Penguin Group, 2010), p. 274.

18. J. Knell, Share Value: How Employee Ownership is Changing the Face of Business (Herts: The All Party Parliamentary Group on Employee Ownership, 2008).

19. Office for National Statistics, 'What is Social Capital'. Guide to Social Capital. http://www.ons.gov.uk/ons/guide-method/ user-guidance/social-capital-guide/the-social-capital-project/guide-to-social-capital.html, accessed 30 September 2011.

20. W. Mansell, 'Co-operative Schools: The Antidote to Academies' The Guardian 15 August 2011.

21. R. Hill, 'The Case of the Missing Organizations: Co-operatives and the Textbooks' The Journal of Economic Education 31 (2000): 281-95.

22. P. Kalmi, 'The Disappearance of Cooperatives from Economics Textbooks' Cambridge Journal of Economics 31 (2007): $625-47$.

23. The support framework present in Mondragón and Emilia Romagna is the design of the co-operative movements themselves, with little or no aid provided by external agencies.

24. The NCEO in the US and the European Research Institute on Cooperative and Social Enterprises (EURICSE) are two such examples.

25. Article 45 of the Italian Constitution recognises the role of co-operatives in Italian society.

26. R. Murray, Co-operation in the Age of Google (Manchester: Co-operatives UK, 2010), p. 11.

27. Co-operative Energy and Norton Energy Community are some of the most recent examples of co-operative energy producers and providers. 


\section{Epilogue}

|||||||||||||||||||||||||||||||||||||||||||||||||||||||||||||||||||||||||||||||||||||||||||||||||||||||||||||||||||||||||||||||||||||||||||||||||||||||||||||||||||||||||||||||||||||||||||||||||||||||||||||||||||||||||||||||||||||||||||||

The global financial crisis has shaken people's faith in the free market and the investor-owned, profit maximising firm creating a groundswell of support for alternative models of enterprise. In response to uncertainties in the economic climate, Borzaga and others argue for the benefits that will arise from having greater economic plurality. Co-operatives and social enterprises are unlikely to replace capitalist enterprise entirely; however, they should play a stronger role in the current economic system. Plurality in the business world is an antidote to the damage that is caused by having one dominant model of enterprise. ${ }^{1}$ Gibson-Graham describes the role of co-operatives as 'enabling ethical economies'.

Of course, the financial crisis presents a very real threat to enterprises of all kinds. Much needed credit for businesses is dwindling, real wages are declining in many countries, and the spending power of the vast majority of citizens has been drastically reduced due to the austerity budgets enacted throughout the European Union. Now, more than ever, we need to remember that enterprising and entrepreneurial behaviour can be a collective activity which takes concern for community and ethical approaches on board.

The United Nation's announcement that 2012 is the International Year of Cooperatives (IYC) provides the perfect opportunity to communicate the message that co-operatives are successful, values-based organisations owned by their members. The IYC has three main objectives:

- To increase awareness about cooperatives and their contributions to socio-economic development and the achievement of the Millennium Development Goals.

- To promote growth of co-operatives to address common economic needs and for socio-economic empowerment.

- To establish appropriate policies by encouraging governments and regulatory bodies to ensure essential frameworks are in place that are conducive to co-operative formation and growth. ${ }^{3}$

It is important that the 2012 IYC not only be a celebration of co-operative achievement to date, but also serve as a springboard for developing the co-operative movement into a greater force for the future.

1. C. Borzaga, S. Depedri, and E. Tortia, 'Organisational Variety in Market Economies and the Role of Co-operative and Social Enterprises: A Plea for Economic Pluralism' Journal of Co-operative Studies 44 (2011): 19-30. See pp. 20-2. The same authors also outline their proposal for greater economic plurality in another paper: C. Borzaga, S. Depedri, and E. Tortia, 'The Role of Cooperative and Social Enterprises: A Multifaceted Approach for an Economic Pluralism' Trento: EURICSE Working Paper, 2009.

2. J. K. Gibson-Graham, 'Enabling Ethical Economies: Cooperativism and Class' Critical Sociology 29 (2003): $123-62$. See p. 157.

3. United Nations, 'What are the Objectives of the Year?' http://social.un.org/coopsyear/objectives-of-the-year.html, accessed 29 September 2011. 


\section{Glossary}

||||||||||||||||||||||||||||||||||||||||||||||||||||||||||||||||||||||||||||||||||||||||||||||||||||||||||||||||||||||||||||||||||||||||||||||||||||||||||||||||||||||||||||||||||||||||||||||||||||||||||||||||||||||||||||||||||||||||||||||

Articles of Association:

a set of rules that define the structure of a UK company and must be registered with Companies House for a business to be incorporated.

Assets:

a financial term for the economic resources a business possesses. Assets can be tangible or intangible but they must produce value for the firm.

Bylaw:

a standing rule, not included in the articles of association, which specifies operational practice and policy of the co-operative.

Capital:

an economic term for a resource that is used to produce goods and services. From a financial perspective, capital refers to the money required by a business to finance its operations.

Capitalism:

an economic system where the means of production are privately owned and operated for profit.

Common ownership:

a principle that ensures that the assets of an organisation are held indivisibly (i.e. cannot be distributed amongst individual owners).

Common shares:

are forms of corporate equity ownership. Individuals who purchase common shares in an organisation are granted the right to participate in governance and profit in proportion to the amount of shares the

Community Interest Company (CIC):

a new company form intended as a brand for social enterprise in the UK. It can be registered as a company limited by guarantee (CLG) or company limited by shares (CLS), has limited profit distribution and an asset lock.

Competitive advantage:

a strategic benefit one organisation has over its competitors. Competitive advantages are created by providing more value to your customers than your competitors can.

Consumer co-operative:

a co-operative whose membership is made up of those who purchase the goods/services

of the business.

Conventional business/company:

see investor-owned business.

Co-operative advantage: the strategic benefit co-operatives have over other forms of enterprise; a co-operative advantage is derived from the unique ownership and governance structure of the business.

Co-operative Development Scotland (CDS):

a subsidiary of Scottish Enterprise, CDS provides support and development services to the co-operative sector in Scotland. 


\section{Co-operatives UK:}

the UK-wide trade body that campaigns for co-operation and works to promote, develop and unite co-operative enterprises.

Corporate governance:

a system for directing, controlling and administering companies.

Credit union:

a type of not-for-profit, consumer co-operative that provides savings, credit and other financial services to its members.

\section{Democracy:}

a system of government where citizens are able to participate in the voting process on an equal basis.

Direct democracy: a form of democracy where people collectively make decisions for themselves, rather than through elected representatives.

Director:

an elected or appointed member of the governing body (board of directors) of an organisation.

Dividend:

a payment made by a business to its shareholders. Payments are usually based on the amount of shares an investor owns. In co-operative terms, dividend refers to the share of surplus a member receives from the co-operative (see Patronage refund).

Employee-owned businesses:

organisations that are partially or entirely owned by their employees.

Equity:

another term for the shares or stock in a company. It can also refer to the concept of fairness.

Ethics:

a branch of philosophy that examines the morality of decisions. It has been applied to business to create the field of professional ethics.

Fair trade:

a social movement that campaigns for the equitable remuneration of producers in developing countries. Under Fairtrade certification, producers are guaranteed a premium price for their produce.

Federation:

a union of autonomous organisations that associate together for a common purpose. Examples of co-operative federations include Co-operatives UK and the International Co-operative Alliance.

Hybrid co-operative:

a co-operative whose membership consists of more than one type of member e.g. a co-operative whose members are drawn from consumers and workers. May also be referred to as a multistakeholder co-operative.

International Co-operative Alliance (ICA):

an independent, non-governmental association which unites, represents and serves co-operatives worldwide. Founded in 1895, ICA has 269 member organisations from 97 countries active in all sectors of the economy. 
Industrial and Provident Society:

an organisation that is registered under the Industrial and Provident Societies Act in the UK.

Co-operatives have traditionally registered as Industrial and Provident Societies.

Industrial democracy:

an arrangement which involved workers making decisions, sharing responsibility and authority

in the workplace.

Investor-owned business:

an organisation where ownership, control and beneficiary rights are granted to those who invest capital in the business.

Member:

a person that belongs to a group or organisation. Co-operative members jointly own and democratically control the enterprise.

Mondragón Corporation (MC):

a network of primarily worker co-operatives in the Basque region of Northern Spain. See chapter 6 for more details.

Patronage refund:

the entitlement a member has to the surplus generated by the co-operative; a member's share of the surplus is based on the amount of trade they conducted with the co-operative in a year. It is more commonly referred to as 'dividend' in the UK.

Preference shares:

special types of share that usually carry no voting rights but have priority over ordinary shares when it comes to the distribution of dividends (or assets in the case of dissolution).

Price/earnings ratio:

a measure of the price paid for a share relative to the annual net income or profit earned by the firm per share.

Primary co-operative:

a co-operative that serves its members directly. An example of a primary co-operative would be a local co-operative that sells groceries directly to its members.

Producer co-operative:

a co-operative whose membership is made up of those who sell their goods/services to the business.

Profit/surplus:

the amount of revenue left over after all costs, depreciation and taxes have been taken into account. In co-operatives, the profit generated by the business is known as the surplus.

Proportionality:

the practice of measuring and distributing effort/reward based on the ratio of one element to another. Co-operatives distribute surpluses based on the amount of input a member contributed to the business.

Representative democracy:

a form of democracy where decisions are made on behalf of people by elected representatives.

Rochdale Pioneers:

a consumer society established in the town of Rochdale, England in 1844, widely cited as the first example of a co-operative enterprise as we know it today (with values and principles). 
Rules:

the equivalent term in an Industrial \& Provident Society co-operative for the Articles of Association of a company.

Scotmid:

the largest independent consumer co-operative in Scotland.

Secondary co-operative:

a co-operative whose membership consists of other co-operatives. The Co-operative Group was originally set up purely as a secondary co-operative (the Co-operative Wholesale Society) to service the buying needs of its consumer society members.

Social enterprise:

a form of organisation whose primary purpose in trading is to achieve social objectives rather than maximise profits.

\section{Society:}

a term for an organisation that is established under the Industrial and Provident Societies or Friendly Societies Acts in the UK

The Co-operative Group:

the largest consumer co-operative in the world with over six million members, focusing primarily on retail and financial services in the UK.

The Fenwick Weavers:

the earliest co-operative enterprise in the world for which there are full records, the Fenwick Weavers' Society in Ayrshire, Scotland, was established in 1761 and began co-operative trading in foodstuffs in 1769 .

Trustee:

a person, whose role is defined in law, who manages an asset (which is held in a trust) on behalf of a beneficiary.

Unallocated patronage:

the amount of surplus generated by member trade that is retained by a co-operative for business purposes. The members have no claim to this portion of the surplus.

Unincorporated:

refers to an organisation that has not registered its Rules or Articles of Association with the relevant legal body. Individuals in an unincorporated organisation remain personally liable for any losses/debt.

Worker co-operative:

a co-operative whose membership consists of those who work in the business. 
Caseplace

Co-operative Development Scotland

Co-operative News

Co-operatives UK

Co-operative Education Trust Scotland

Employee Ownership Association

European Federation of Employee Share Ownership

International Co-operative Alliance

John Lewis Partnership

Mutuo

National Center for Employee Ownership

National Cooperative Business Association

Ohio Employee Ownership Center

Scottish Agricultural Organisation Society

Sustainable Employment

UK Society for Co-operative Studies www.caseplace.org

www.cdscotland.co.uk

www.thenews.coop

www.uk.coop

www.cets.coop

www.employeeownership.co.uk

www.efesonline.org

www.ica.coop

www.johnlewispartnership.co.uk

www.mutuo.co.uk

www.nceo.org

www.ncba.coop

www.oeockent.org

www.saos.co.uk

www.sustainableemployment.eu

www.co-opstudies.org 


\section{Select bibliography}

||||||||||||||||||||||||||||||||||||||||||||||||||||||||||||||||||||||||||||||||||||||||||||||||||||||||||||||||||||||||||||||||||||||||||||||||||||||||||||||||||||||||||||||||||||||||||||||||||||||||||||||||||||||||||||||||||||||||||||||

Abrahamsen, M. A. Cooperative Business Enterprise. New York: McGraw-Hill, 1976.

Alchian, A. A. and H. Demsetz. 'Production, Information Costs, and Economic Organization' American Economic Review 62 (1972): 777-95.

Atherton, J., J. Birchall, E. Mayo, and G. Simon. Practical Tools for Defining Co-operatives. Manchester: Co-operatives UK, 2011.

Barkett, W. and G. Pridbeam. Co-operative Enterprises in Italy, Portugal and Spain: History, Development and Prospects. Bristol: University of Bristol, 1991.

Bateman, D. I., J. R. Edwards, and C. Levay. 'Agricultural Cooperatives and the Theory of the Firm' Oxford Agrarian Studies 8 (1979): 63-81.

Batstone, E. 'Organization and Orientation: A Life Cycle Model of French Co-operatives' Economic and Industrial Democracy 4 (1983): 139-61.

Ben-Ner, A. 'On the Stability of the Cooperative Type of Organization' Journal of Comparative Economics 8 (1984): 247-60.

Bibby, A. From Colleagues to Owners: Transferring Ownership to Employees. London: Employee Ownership Association, 2009.

Birchall, J. Co-op: the people’s business. Manchester: Manchester University Press, 1994.

Birchall, J. 'The Co-operative Values and Principles: A Commentary' Journal of Co-operative Studies 30 (1997): 42-69.

Birchall, J. A Comparative Analysis of Co-operative Sectors in Scotland, Finland, Sweden and Switzerland. Glasgow: Co-operative Development Scotland, 2009.

Birchall, J. People-centred Businesses: Co-operatives, Mutuals and the Idea of Membership. London: Palgrave MacMillan, 2010.

Birchall, J. and R. A. Simmons. 'What Motivates Members to Participate in Co-operative and Mutual Businesses?' Annals of Public \& Cooperative Economics 75 (2004): 465-95.

Birchall, J. and L. H. Ketilson. Resilience of the Cooperative Business Model in Times of Crisis. Geneva: International Labour Organisation, 2009.

Blair, M., D. Kruse, and J. Blasi. 'Is Employee Ownership an Unstable Form? Or a Stabilizing Force?' in T. Kochan, and M. Blair (eds). The New Relationship: Human Capital in the American Corporation. Washington: The Brookings Institution, 2000.

Blasi, J. R., M. Conte, and D. Kruse. 'Employee Stock Ownership and Corporate Performance Among Public Companies' Industrial and Labor Relations Review 50 (1996): 60-79.

Blasi, J., D. Kruse, J. Sesil, and M. Krouiinova. 'An Assessment of Employee Ownership in the United States with implications for the EU' International Journal of Human Resource Management 14 (2003): 893-919.

Blasi, J., D. Kruse, and A. Bernstein. In the Company of Owners. New York: Basic Books, 2003.

Blumbe, E. B. 'Methods of Measuring Success and Effect in a Co-operative' in E. Dulfer and W. Hamm (eds). Co-operatives: In the Clash Between Member Participation, Organisational Development and Bureaucratic Tendencies. London: Quiller Press, 1985.

Bonin, J. P., D. C. Jones, and L. Putterman. 'Theoretical and Empirical Studies of Producer Cooperatives: Will Ever the Twain Meet?' Journal of Economic Literature 31 (1993): 1290-1320. 
Borzaga C., S. Depedri, and E. Tortia. 'The Role of Cooperative and Social Enterprises: A Multifaceted Approach for an Economic Pluralism' Trento: EURICSE Working Paper, 2009.

Borzaga, C., S. Depedri and E. Tortia. 'Organisational Variety in Market Economies and the Role of Co-operative and Social Enterprises: A Plea for Economic Pluralism' Journal of Co-operative Studies 44 (2011): 19-30.

Bowles, S. Microeconomics: Behavior, Institutions, and Evolution. New Jersey: Princeton University Press, 2006.

Brøgger, B. 'An Innovative Approach to Employee Participation in a Norwegian Retail Chain' Economic and Industrial Democracy 31 (2010): 477-95.

Busck, O., H. Knudsen, and J. Lind. 'The Transformation of Employee Participation: Consequences for the Work Environment' Economic and Industrial Democracy 31 (2010): 285-305.

Chaddad, F. R. and M. L. Cook. 'Understanding New Cooperative Models: An Ownership-Control Rights Typology' Review of Agricultural Economics 26 (2004): 348-60.

Coates, K (ed). The New Worker Co-operatives. Nottingham: Spokesman Books, 1976.

Conover, M. 'The Rochdale Principles in American Co-Operative Associations' The Western Political Quarterly 12 (1959): 111-22.

Co-operatives UK. The UK Co-operative Economy 2011: Britain's Return to Co-operation. Manchester: Co-operatives UK, 2011.

Co-operatives UK. The UK Co-operative Economy 2010: A Review of Co-operative Enterprise. Manchester: Co-operatives UK, 2010.

Co-operatives UK. Worker Co-operative Code of Governance. Manchester: Co-operatives UK, 2009.

Co-operatives UK. Simply Governance. Manchester: Co-operatives UK, 2011.

Co-operatives UK. Simply Legal (2nd edition). Manchester: Co-operatives UK, 2009.

Co-operatives UK. Simply Finance. Manchester: Co-operatives UK, 2011.

Co-operatives UK. Suma Wholefoods, case study no. 6. Manchester: Co-operatives UK, n.d.

Corcoran, H. and D. Wilson. The Worker Co-operative Movements in Italy, Mondragón and France: Context, Success Factors and Lessons. Calgary: Canadian Worker Co-operative Federation, 2010.

Cornforth, C. 'The Governance of Cooperatives and Mutual Associations: A paradox Perspective' Annals of Public and Cooperative Economics 75 (2004): 11-32.

Cornforth, C. 'Patterns of Co-operative Management: Beyond the Degeneration Thesis' Economic and Industrial Democracy 16 (1995): 487-523.

Cornforth, C. 'Making Sense of Co-operative Governance: Competing Models and Tensions' Review of International Co-operation 95 (2002): 51-7.

Cornforth, C. 'Some Factors Affecting the Success or Failure of Worker Co-operatives: A Review of Empirical Research in the United Kingdom' Economic and Industrial Democracy 4 (1983): 163-90.

Cornforth, C., A. Thomas, R. G. Spear, and J. M. Lewis. Developing Successful Worker Co-operatives. London: Sage, 1988.

Cotter, A. 'Social Consequences of Employee Ownership' Proceedings of the Academy of Political Science 11 (1925): 131-33.

Craig, B. and Pencavel, J. 'The Behavior of Worker Cooperatives: The Plywood Companies of the Pacific Northwest' The American Economic Review 82 (1992): 1083-1105. 
Cronan, G. '2007 Global 300 Launch'. Presentation to the General Assembly of the International Co-operative Alliance.

Dahl, R., A. A Preface to Economic Democracy. Berkeley: University of California Press, 1985.

Davis, P. 'Management Development for Co-operatives: A Review' Journal of Co-operative Studies 29 (1997): 53-68.

Davies, W. Reinventing the Firm. London: Demos, 2009.

Department for Business, Innovation and Skills. 'Small and Medium-sized Enterprise Statistics for the UK and Regions 2009' 13 October 2010. http://stats.bis.gov.uk/ed/sme/, accessed 12 August 2011.

Doucouliagos, C. 'Worker Participation and Productivity in Labor-Managed and Participatory Capitalist Firms: A Meta-Analysis' Industrial and Labor Relations Review 49 (1995): 58-77.

Dow, G. Governing the Firm: Workers' Control in Theory and Practice. Cambridge: Cambridge University Press, 2003.

Ellerman, D. P. The Mondragón Cooperative Movement. Harvard Business School Case No. 1-384-270. Boston: Harvard Business School, 1984.

Ellerman. D. P. The Democratic Worker-Owned Firm. London: Unwin Hyman Ltd, 1990.

Employee Ownership Association (EOA). 'About Employee Ownership'. http://www.employeeownership. co.uk/employee-ownership/about-employee-ownership/, accessed

7 May 2011.

Erdal, D. Local Heroes: How Loch Fyne Oysters Embraced Employee Ownership and Business Success. London: Penguin Group, 2008.

Erdal, D. Beyond the Corporation: Humanity Working. London: The Bodley Head, 2011.

Estrin, S. and D. C. Jones. 'The Viability of Employee-Owned Firms: Evidence from France' Industrial and Labor Relations Review 45 (1992): 323-38.

Fanning, C. and D. O'Mahony. 'Economic Theory of the Worker Co-operative:

An Exposition' Economic and Industrial Democracy 4 (1983): 225-41.

Fernández, J. R. La Experiencia Cooperativa de Mondragón: 1956-20oo. Guipúzcoa: Mondragón Corporacion Cooperativa, 2001.

Fetzer, T. 'The Europeanization of Employee Participation: Britain and Germany in Historical and Contemporary Perspective' Economic and Industrial Democracy 31 (2010): 3-8.

Field Fisher Waterhouse. '2010 saw employee owned company shares outperform the FTSE All-Share according to Employee Ownership Index'. http://www.ffw.com/press-releases/2011/mar/employee-ownedcompany-shares.aspx, accessed 16 June 2011.

Financial Services Authority. Annual Report of the Registry of Friendly Societies 200o-2001. London: Registry of Friendly Societies, 2002.

Frederick, D. A. 'Co-ops 101: An Introduction to Cooperatives' Cooperative Information Report 55. U.S. Department of Agriculture, 1997.

Ghemawat, P. and J. W. Rivkin. 'Creating Competitive Advantage' Harvard Business Review, 1998.

Gibson-Graham, J. K. 'Enabling Ethical Economies: Cooperativism and Class' Critical Sociology 29 (2003): 123-62.

Gold, M. 'Employee Participation in the EU: The Long and Winding Road to Legislation' Economic and Industrial Democracy 31 (2010): 9-23. 
Hancock, M. The Cooperative District of Imola: Forging the High Road to Globalization. Progress Report, Research Project on the Cooperative District of Imola, Prepared for MUEC, 2004-5.

Hansmann, H. The Ownership of Enterprise. Cambridge: Harvard University Press, 1996.

Henehan, B. M. and B. L. Anderson. Decision Making in Membership Organizations: A Study of Fourteen U.S. Cooperatives. New York: Cornell University, 1994.

Hill, A. 'It's the managers, not the model' Financial Times, 9 May 2011. http://www.ft.com/cms/ s/o/6b8db826-7a80-11eo-8762-0o144feabdco.html\#axzz1XvjeFfDL, accessed 9 May 2011.

Hill, R. 'The Case of the Missing Organizations: Co-Operatives and the Textbooks' The Journal of Economic Education 31 (2000): 281-95.

Hind, A. M. 'The Changing Values of the Cooperative and Its Business Focus' American Journal of Agricultural Economics 79 (1997): 1077-82.

Hoffmann, E. A. 'Dispute Resolution in a Worker Cooperative: Formal Procedures and Procedural Justice' Law \& Society Review 39 (2005): 51-82.

Hunt, G. C. 'Division of Labour, Life Cycle and Democracy in Worker Co-operatives' Economic and Industrial Democracy 13 (1992): 9-43.

Hyman, J. and B. Mason. Managing Employee Involvement and Participation. London: Sage, 1995.

International Co-operative Alliance (ICA). 'Statement on the Co-operative Identity'. http://www.ica.coop/ coop/principles.html, accessed 4 May 2011.

International Co-operative Alliance (ICA). 'Statistical Information on the Co-operative Movement'. http:// www.ica.coop/coop/statistics.html, accessed 4 August 2011.

Jacobsen G. 'Cooperative and Training Dimensions in Entrepreneurship: A Study of the Methodology of the Saiolan Centre in Mondragón' INUSSUK Arctic Research Journal

1 (2001): 137-46.

Jansson, S. and A. B. Hellmark (eds). Labour-Owned Firms and Worker Cooperatives. Hants: Gower Publishing Company Limited, 1986.

Jensen, M. C. and W. H. Meckling. 'Rights and Production Functions: An Application to Labor Managed Firms and Codetermination' Journal of Business 52 (1979): 469-506.

Jones, D. C. 'The Productivity Effects of Worker Directors and Financial Participation by Employees in the Firm: The Case of British Retail Cooperatives' Industrial and Labor Relations Review 41 (1987): 79-92.

Jones, D. C. 'British Producer Co-operatives' in K. Coates (ed.). The New Worker Co-operatives.

Nottingham: Spokesman Books, 1976.

Kaarsemaker, E., A. Pendleton, and E. Poutsma. 'Employee Share Ownership Plans: A Review' Working Paper 44. The York Management School, 2009.

Kalmi, P. 'The Disappearance of Cooperatives from Economics Textbooks' Cambridge Journal of Economics 31 (2007): 625-47.

Keasey, K., S. R. Thompson, and M. Wright. Corporate Governance: Economic, Management and Financial Issues. Oxford: Oxford University Press, 1997.

Keasey, K., H. Short, and M. Wright. 'The Development of Corporate Governance Codes in the UK' in K. Keasey, S. R. Thompson, and M. Wright (eds). Corporate Governance: Accountability, Enterprise and International Comparisons. West Sussex: John Wiley \& Sons Ltd, 2005.

Kelsey, D. and F. Milne. 'Takeovers and Cooperatives: Governance and Stability in Non-corporate Firms' Journal of Economics 99 (2010): 193-209. 
Kennedy, L. (ed). Economic Theory of Co-operative Enterprises. Oxford: The Plunkett Foundation for Co-operative Studies, 1983.

Kinloch, J. and J. Butt. History of the Scottish Co-operative Wholesale Society. Glasgow: Co-operative Wholesale Society Limited, 1981.

Kleer, J. 'The Co-operative System - Between Participation and Growth' in E. Dulfer and W. Hamm (eds). Co-operatives: In the Clash Between Member Participation, Organisational Development and Bureaucratic Tendencies. London: Quiller Press, 1985.

Klein, K. 'Employee Stock Ownership and Employee Attitudes: A test of Three Models' Journal of Applied Psychology 72 (1987): 319-32.

Knell, J. Share Value: How employee ownership is changing the face of business. Herts: The All Party Parliamentary Group on Employee Ownership, 2008.

Kramer, B. 'Employee Ownership and Participation Effects on Outcomes in Firms Majority EmployeeOwned Through Employee Stock Ownership Plans in the US' Economic and Industrial Democracy 31 (2010): 449-76.

Lampel, J., A. Bhalla, and J. Pushkar. Model Growth: Do Employee-Owned Businesses Deliver Sustainable Performance? London: Employee Ownership Association, 2010.

Lewis, A. and N. Klein. The Take. Brighton: Artefact Films, 2004.

Logue, J. and J. Yates. The Real World of Employee Ownership. New York: Cornell University, 2001.

Lowitzsch, J., I. Hashi, and R. Woodward (eds). The PEPPER IV Report: Benchmarking of Employee Participation in Profits and Enterprise Results in the Member and Candidate Countries of the European Union. Berlin: Inter-University Centre Split/Berlin, Institute for Eastern European Studies, Free University of Berlin, 2008.

Mamudi, S. 'Lehman folds with record $\$ 613$ billion debt' MarketWatch 15 September 2008. http://www. marketwatch.com/story/lehman-folds-with-record-613-billion-debt?siteid=rss, accessed 3 September 2011.

Margretta, J. ‘Why Business Models Matter’ Harvard Business Review May 2002.

Maxwell, W. A History of Co-operation in Scotland. Glasgow: Scottish Section of the Co-operative Union, 1910.

McFadzean, J. The Co-operators - A History of the Fenwick Weavers. Kilmarnock: East Ayrshire North Communities Federation Ltd, 2008.

McLeod, A. 'Deciding how to Decide' Cooperative Starter Series \#4. Northwest Cooperative Development Center, 2008.

Meister, A. 'Democratie et participation dans les associations volontaires' Sociologie du Travail 3 (1961): $236-52$.

Mellor, M., J. Hannah, and J. Stirling. Worker Cooperatives in Theory and Practice. Milton Keynes: Open University Press, 1988.

Millana, M. Exercising Employee Shareholders'Rights in Employee-owned Companies: Sociedades laborales. Presentation to the Spanish Business Confederation of Employee-owned Companies, Rome, 16 September 2010.

Miyazaki, H. 'On Success and Dissolution of the Labor-managed Firm in the Capitalist Economy' Journal of Political Economy 92 (1984): 909-31.

Mullins, J. and R. Kumisar. Getting to Plan B: Breaking Through to a Better Business Model. Boston: Harvard Business School Press, 2009.

Murray, R. Co-operation in the Age of Google. Manchester: Co-operatives UK, 2010. 
National Center for Employee Ownership (NCEO). 'How an Employee Stock Ownership Plan (ESOP) Works'. http://www.nceo.org/main/article.php/id/8/, accessed 23 May 2011.

National Center for Employee Ownership (NCEO). 'A Statistical Profile of Employee Ownership' updated April 2011. http://www.nceo.org/main/article.php/id/2/, accessed

16 May 2011.

Nelson-Jones, J. and G. Nuttall. Employee Ownership: Legal and Tax Aspects. London: Fourmat Publishing, 1987.

Nilsson, J. 'Organisational Principles for Co-operative Firms' Scandinavian Journal of Management 17 (2001): 329-56.

Nilsson, J. 'The Nature of Cooperative Values and Principles: Transaction Cost theoretical Explanations' Annals of Public and Cooperative Economics 67 (1996): 633-53.

Nuttall, G. and S. Anderson. Employee Benefit Trusts booklet. London: Equity Incentives, 2001.

Oakeshott, R. The Case for Workers' Co-ops (2nd edition). Hampshire: Palgrave Macmillan, 1990.

Oakeshott, R. Jobs \& Fairness: The Logic and Experience of Employee Ownership. Norwich: Michael Russell, 2000.

Ocean Spray. 'Our Growers Cooperative'. http://www.oceanspray.co.uk/heritage/growers, accessed 14 June 2011.

Ontario Co-operative Association. 'Co-operative Board \& Governance Part 1'. http://www.youtube.com/watc h?v=1RUb463Upow\&feature=related, accessed 16 June 2011.

Ortega, P. O. 'Agricultural Co-operation in Spain. Developing Research Goals and a Literature Review on the Issue of Success Factors for Co-operative Management Applied in the Case of an Olive Oil Co-operative' The International Journal of Co-operative Management 5 (2010): 46-53.

Osterwalder, A and Y. Pigneur. Business Model Generation: A Handbook for Visionaries, Game Changers, and Challengers. Hoboken: John Wiley \& Son, 2010.

Park, R., D. Kruse, and J. Sesil. 'Does Employee Ownership Enhance Firm Survival?' Advances in the Economic Analysis of Participatory and Labor-Managed Firms 8 (2004): 3-33.

Parnell, E. Enterprise Models. http://www.co-oppundit.org/enterprise_models.html, accessed 20 May 2011.

Paton, R. (ed). Reluctant Entrepreneurs. Milton Keynes: Open University Press, 1989.

Pendleton, A. 'The Costs and Benefits of Employee Ownership' extract from inaugural lecture 'When Workers Own Business: What Happens, and Why' at the University of York, 14 December 2009. http://www.youtube. com/watch?v=p6wFGquERLk, accessed 4 July 2011.

Pendleton, A. 'The Three Forms of Employee Ownership' extract from inaugural lecture 'When Workers Own Business: What Happens, and Why' at the University of York, 14 December 2009. http://www.youtube.com/ user/ProfAndrewPendleton\#p/a/u/1/vNoA-oYVEkk, accessed 4 July 2011.

Pendleton, A. Employee Ownership, Participation and Governance. London: Routledge, 2001.

Pérotin, V. 'Entry, Exit, and the Business Cycle: Are Cooperatives Different?' Journal of Comparative Economics 34 (2006): 295-316.

Pérotin, V. and A. Robinson. 'Employee Participation in Profit and Ownership: A Review of the Issues and Evidence' Paper prepared for the European Parliament, December 2002.

Pierce, J. L. and C. Furo. 'Employee Ownership: Implications for Management' Organizational Dynamics 18 (1990): 32-43. 
Pierce, J. L. and L. Rodgers. ‘The Psychology of Ownership and Worker-Owner Productivity' Group and Organisation Management 29 (2004): 588-613.

Plywood Pioneers Association. 'Olympia Veneer Company' Plywood in Retrospect No. 7. Tacoma: Plywood Pioneers Association, 1969.

Ramesh, R. 'Basque Country's Thriving Big Society' The Guardian 30 March 2011. http://www.guardian. co.uk/world/2011/mar/30/basque-country-big-society-spain, accessed 4 May 2011.

Rhodes, R. 'British Co-operative History' Paper presented at the conference A Global History of the Co-operative Movement, 20th November 2009.

Ricketts, M. The Economics of Business Enterprise. Cheltenham: Edward Elgar, 2002.

Ridley-Duff, R. 'Cooperative Social Enterprises: Company Rules, Access to Finance and Management Practice' Social Enterprise Journal 5 (2009): 50-68.

Ridley-Duff, R. J. 'Communitarian Governance in Social Enterprises: case evidence from the Mondragón Cooperative Corporation and School Trends Ltd’ Social Enterprise Journal 6 (2010): 125-45.

Ridley-Duff, R. and M. Bull. Understanding Social Enterprise: Theory \& Practice. London: Sage, 2011.

Robertson, N. The Co-operative Movement and Communities in Britain, 1914-1960: Minding Their Own Business. Surrey: Ashgate Publishing Group, 2010.

Rodgers, L. Hybrid Cooperatives: Challenges and Advantages. Oakland: National Center for Employee Ownership, 2008.

Rothschild, J. and R. Russell. 'Alternatives To Bureaucracy: Democratic Participation In The Economy’ Annual Review of Sociology 12 (1986): 307-28.

Rousseau, D. and Z. Shperling. 'Pieces of the Action: Ownership and the Changing Employment Relationship' Academy of Management Review 28 (2003): 553-70.

Simon, G. and E. Mayo. Good Business? Public Perceptions of Co-operatives. Manchester: Co-operatives UK, 2010 .

Smith, A. An Inquiry into the Nature and Causes of the Wealth of Nations. London: Methuen \& Co., 1776.

Smith, S. Robert Owen: Utopian realist. Manchester: The Co-operative Group, 2008.

Spear, R. 'Membership Strategy for Co-operative Advantage' Journal of Co-operative Studies 32 (2000): 102-23.

Spear, R. 'Governance in Democratic Member-Based Organisations' Annals of Public and Cooperative Economics 75 (2004): 33-60.

Stiglitz, J. E. Economics (2nd edition). New York: W.W. Norton \& Co, 1997.

Staber, U. 'Worker Cooperatives and the Business Cycle: Are Cooperatives the Answer to Unemployment?' American Journal of Economics and Sociology 52 (1993): 129-43.

Szabó, G. G. 'Co-operative Identity - A Theoretical Concept for Dynamic Analysis of Practical Co-operation: The Dutch Case' Paper prepared for presentation at the XIth International Congress of the EAAE (European Association of Agricultural Economists), 'The Future of Rural Europe in the Global Agri-Food System', Copenhagen, Denmark: August 24-27, 2005.

The Co-operative Bank. 'Why Do We Need Ethical Policies'. http://www.goodwithmoney.co.uk/why-do-weneed-ethical-policies/, accessed 4 May 2011.

Thomas, A. and C. Cornforth. 'The Survival and Growth of Worker Co-operatives:

A Comparison with Small Businesses' International Small Business Journal 8 (1989): 34-50.

Thornley, J. Workers' Co-operatives. London: Heinemann, 1981. 
Tuominen, P., I. Jussila, and N. Rantanen. 'Managerial Competence in Consumer Co-operatives: Inducing Theory from Empirical Observations' International Journal of Co-operative Management 5 (2010): 9-22.

United States Department of Agriculture. 'Cooperative Member Responsibilities and Control' Cooperative Information Report 1, Section 7, 1990.

US Federation of Worker Cooperatives. 'About Worker Cooperatives'. http://www.usworker.coop/ aboutworkercoops, accessed 25 June 2011.

Voestalpine AG. 'voestalpine Employee Participation'. http://www.voestalpine.com/group/en/group/ employee-participation/, accessed 15 August 2011.

Voestalpine AG. ‘The Basic Principles of Employee Participation'. http://www.voestalpine.com/group/en/ group/employee-participation/grundsaetze-der-mitarbeiterbeteiligung.html, accessed 15 August 2011.

Voorhis, J. A New Look at Principles and Practices of Cooperatives. Washington: Cooperative League of the USA, 1966.

Ward, B. ‘The Firm in Illyria: Market Syndicalism’ American Economic Review 48 (1958): 566-89.

Webb, T., L. Benander, L. Cirillo, and C. Lagier. Making the Most of Our Cooperative Advantage. Greenfield: Cooperative Life, 2006.

Webb, S. and B. Industrial Democracy. London: Longmans, 1897.

Webb, S. and B. The Cooperative Movement. London: Longmans, 1914.

Webb, S. and B. Consumers Co-operative Movement. (Published by the authors), 1921.

Wilkinson, R. and K. Pickett. The Spirit Level: Why Equality is Better for Everyone. London: Penguin Group, 2010.

Williams, E. E. and M. C. Findlay.' Corporate Governance: A Problem of Hierarchies and Self Interest' American Journal of Economic and Sociology 43 (1984): 19-36.

Wonnacott, P. and R. J. Wonnacott. Economics (4th edition). New Jersey: Wiley, 1990.

Zeuli, K. and R. Cropp. Cooperatives: Principles and practices in the 21st century. Wisconsin: University of Wisconsin Center for Cooperatives, 2004.

'Co-op Moves to Fairtrade Coffee' BBC News 13 November 2003. http://news.bbc.co.uk/1/hi/ business/3264671.stm, accessed 19 April 2011.

'Timeline: Credit Crunch to Downturn' BBC News 7 August 2009. http://news.bbc.co.uk/1/hi/7521250.stm, accessed 3 September 2011.

'Equal Exchange - fair trade, worker-ownership, and great returns for investors!' American Worker Cooperative 2 March 2011. http://american.coop/content/equal-exchange-\%E2\%80\%93-fair-trade-workerownership-and-great-returns-investors, accessed 4 July 2011.

'Fenwick Weavers' Society’Wikipedia article. http://en.wikipedia.org/wiki/Fenwick_Weavers\%27_Society, accessed 3 May 2011.

'Ocean Spray’s Creative Juices' Businessweek 15 May 2006. http://www.businessweek.com/magazine/ content/o6_20/b3984097.htm, accessed 14 June 2011.

'The Fairtrade Foundation welcomes the Co-operative's new ethical operating plan' Fairtrade Foundation press release 18 February 2011. http://www.fairtrade.org.uk/press_office/press_releases_and_statements/ february_2011/the_fairtrade_foundation_welcomes_the_cooperatives_new_ethical_operating_plan.aspx, accessed 22 April 2011. 
Al Jazeera

Alchian, A. A

Allied Plywood

All Party Parliamentary Group on Employee Owneship

Amul

Anderson, D

Annan, K

appreciation rights

arguments against employee ownership

arguments for employee ownership

social

economic

political

rights

Aristotle

Arizmendiarrieta, J. M

Articles of Association

$89,90,92,149$

$33,72,104,105$

balancing economic and democratic aims

Bank of England

Barclays

Batstone, E

Baxi Partnership

$\mathrm{BBC}$

Ben-Ner, A

Beyond Grey Pinstripes

Beyster, B

Bhalla, A

Bibby, A

Big Society

Big Society Network

Birchall, J

Blair, M

Blasi, J

BNP Paribas

board of directors responsibilities role

125,161

128-32:

126-7

128

122

47

16,22

110,147

38

143

164

138

158-9

$124,125,130$

$124,125,130$

$49,51,52,53,72,85,85$ :
38 Borzaga, C

166

129 Bowden, $\mathrm{F}$

130

112-3 Bridges: The Actors' Agency 73

Brown, D

52

Bull, $\mathrm{M}$

73

business cycle

144

Business in the Community

26

business model

$37,41,140$

business schools and co-operative studies

161

121-8: business succession

$138,139,163$

$122-6$

Caja Laboral Popular (CLP)

93

Campaign for Sustainable

Employment

96

$11,15,17$

capital

see also shares:

raising $19,40-1,71,72,83,109,130,162$

return on

$18,44,71,131$

importance of

35,40

role

$18,21,70$

member contribution

$18,54,55,69,82,110$

capitalism

121,155

145

Capital Ownership Group

133

Carey Center for Democratic Capitalism

133

CASS Business School

122

Childbase

138

Clansman Dynamics

139

105-6 classification of co-operatives

65-9

124-5 CLG (company limited by guarantee)

72,73

CLS (company limited by shares)

72

community

$16,19,20,24,32,40,42,57,58,65,67,70,84,93$, $95,126,127,128,164,166$

Companies Act

Companies House

54,74

comparison of enterprise models

42

11 competitive advantage

$21,22,23,37,53,126$

CONFESAL

156

conventional company/business/enterprise 
see investor-owned

Co-operantics

co-operative advantage see also competitive advantage

Co-operative and Community Benefit Societies Act 2010

Co-operative and Community Finance

Co-operative Banking Group

Co-operative Business Consultants

Co-operative Development Scotland (CDS)

$72,147,160$

Co-operative Enterprise Hub

Co-operative Global News Hub

co-operative management worker co-operatives

Co-operative Retail Trading Group (CRTG)

co-operatives:

decision-making

$52-3,54,55,57,68,69,81,83-5,86,146$

business model

$15,31-42$

shares

values and principles

$32-3,40,55,82,88,142$

$15-24,37,38-40,58,72,73$

status

$151-5$

purpose

$32,37,42,55,71,80$

ownership

co-operatives and government

Co-operatives UK $20,53,60,83,84,96,153,159,163,164$

co-ownership

Cornforth, C

$56,80,143,144$

corporate social responsibility (CSR)

$16,20,22$

cost of goods sold (COGS)

38

Crédit Agricole

20

Credit unions

Dahl, R

$20,21,163$

123,128

Debenhams

degeneration of employeeowned companies

democracy $11,16,19,85,102,122,128,145-6$

democratic decision making consensus simple majority supermajority

democratic enterprise:
Erdal, D

Eroski

127,130

role in tackling pressing issues

157-8

public perception

159-60

development

161-2

Demsetz, $\mathrm{H}$

129

Department for Business, Innovation and Skills

dividend

$32,40,68,7380,82,107$

Doucouliagos, C

Dow, G

128,144

Dragon's Den

40

Drumchapel Credit Union

65

economic efficiency

$81,122,128,129$

economic theory of worker co-operatives

Edelman Trust Barometer 159

Edinburgh Bicycle Co-operative

87

education see also training $10,11,17,19,33,49,55,90,93,94,123,127,139$, 157,161

Ellerman, D $79,88,90$

Emilia Romagna 155,162

employee ownership: raising finance $\quad 130$

definition 102

ownership 103

governance 103

lifecycle 144

beneficiaries 104

rationale 102

formation 137-41

decline 141-3

social benefits $\quad 127$

pay

Employee Ownership Association (EOA)

$83,102,115,122,155,159,160$

equity

see shares

69,90

Estrin, S

144

ethics

23,38

European Federation of Share

Ownership (EFES) 115

European Union (EU) 166

Evergreen Cooperatives $\quad 95$ 
Excellence By Owners (EBO)

factors of production

Fairtrade

Fernández, J. R

Field Fisher Waterhouse

finance

see also capital; shares:

member loans

financial crisis

$11,34,39,163,166$

Financial Services Authority (FSA)

$54,70-1$

Financial Times

Ford

forms of employee ownership:

direct shares

EBT (employee benefit trust)

hybrid

ESOP (employee stock ownership plan) summary

104-5

Foundation for Enterprise Development (FED) 147

FTSE All Share (London stock exchange) 101, 126

Furobotn, E

Furo, C

Gibson-Graham, J. K

Global300 project

Google

governance:

corporate

definition

co-operative

overview

theories of

democratic

worker co-operative

governing document see also articles of association

graphics.coop

GreenCity Wholefoods

Green Schools Revolution

gross margin model

Hanover Consumer Cooperative Society

Hansmann, $\mathrm{H}$

Harness Care Co-operative

Heart of England

Her Majesty's Revenue and Customs (HMRC)
106-8

109-10

$110-13$

114

119

140

$21,49-50,58$$$
\text { (1) }
$$

(1)

$34,49,50$

51

$51-2$

$83-4$

$52,53-4,68$

information rights

International Co-operative Alliance (ICA)

$15,26,153$

International Labour

Organisation (ILO)

96

investment model

investor-owned company/

business/enterprise

$11,15,16,18,20,24,26,32,39,42,49,50,51-2$, $81,108,128,129,132,142,161,162,166$

Jensen, M. C

129,131

John Lewis Partnership

$102,107,108-9,115$

Jones, D

$123,143,144$

Jussila, I

57

Kalmi, P

161

Kelso, L

110

Ki-Moon, B (UN Secretary General) 29

Kleer, J

50

Klein, $\mathrm{K}$

127

38 Klein, N

140

20, 66, 86 Kruse, D

$124,125,130$

20 Kumisar, R

39

38 Lagun-Aro

94

21 Lampel, J

124-5

122, 129 Lane, A

110

72 Legacoop

155

65

105

legal forms

comparison of

70-2:

choice of

73

73 
Lehman Brothers

Lennoxtown Friendly Victualling Society

Lewis, A

Lewis, J. S

Lincolnshire Co-operative Ltd

liquidation rights

Lloyds TSB

Loch Fyne Oysters

Long, $\mathrm{R}$

Mackin, C

market failure

Mayo, E

Meckling, W. H

mediaco-op

Meister, A

Mellor, M

membership:

ownership rights and responsibilities

engagement and participation

governance responsibilities

role

classification in worker co-operatives

Menem, C

Millennium Development Goals

Mill, J. S

MIT Community Innovators Lab

Miyazaki, $\mathrm{H}$

Mondragón Corporation (MC) $18,20,39,40,65,69,88,89-94,143,157,162$

Mondragón University

Mullins, J

94

39

mutuals

$11,56,58,70,152,158,163$

Mutuals Information Service (MIS)

Mutuals Register

National Center for

Employee Ownership (NCEO) 123, 141, 155, 156

National Cooperative Business Association

net assets

Noble, J

Northern Rock

Oakeshott, R

140

141

160

$32-3$

54-5

11,163

113
11 Ocean Spray

Ohio Employee Ownership

Association (OEOC)

115,147

Olympia Veneer

142

operating model

Orbea

organisational/

management hierarchies

$142,145-6$

organisational

performance

80-1, 102, 110, 122, 125, 142

Ortega, P. O

Ownership Associates

115,147

Parker, M

Parnell, E

$18,33,68,69,79$

145 patronage refund

$33,34,35-6$

82 Pendleton, A

$89,103,114$

Peninsula Newspapers Incorporated

110

People and Planet

164

Pérotin, $\mathrm{V}$

$123,143,144$

personal rights

$33,49,51-2,88$

Pickett, K

$126,157,158$

Pierce, J. L

140

Proctor and Gamble

155

profit

$$
\text { see surplus }
$$

property rights

$49,51-2,88$

provident

Pushkar, J

124,125

Rantanen, $\mathrm{N}$

57

relationship between labour and capital in a worker co-operative

80

renewable energy

revenue model

38

Ricketts, M

$123,129,131$

Ridley-Duff, R

Robinson, A

Rochdale Society of Equitable Pioneers 17, 18, 39, 44 
worker co-operative

Rosen, C

Rousseau, D

Sanders, E \& P

Science Applications International Corporation (SAIC)

105-6, 109

Scotmid

Scottish Agricultural Organisation Society (SAOS)

shareholders see investor-owned company/business/enterprise shares

see also capital:

co-operative

32,55

employee ownership

investor ownership

$102,104-13,124,143,162$

$18,72,82,88$

Shperling, Z

102

Simmons, $\mathrm{R}$ 58

Simon, G 160

Smile 22

social capital 161

social enterprise

$42,158,160,166$

social identity

social objectives/ initiatives

$24,32,33,81,88,91,157$

social responsibility

Sociedades laborales

$16,21,24$

society see co-operatives

Staber, U

Stanford, L

Suma Wholefoods

surplus

use of

generation of

role of

worker co-operatives

distribution of

sustainability $18,19,20,38,52,79,93,94,138,141,144$

Tesco

The Co-operative Bank

21-2, 24, 38

The Co-operative Group 20, 21, 38, 65, 66, 67-8, 72

The Equality Trust

156

99

$68-9,85$

128, 131:

23,49

$80,82,129,142$

$34-6,6988,104$
85 The ESOP Association

115

141 The European Confederation of Workers'

102 Cooperatives, Social Cooperatives and Social and Participative Enterprises

The Fairtrade Foundation

The International Organisation of Industrial, Artisanal and Service Producers' Cooperatives 96

The Plunkett Foundation

26

The Take 140

The Very People

Thomas, A

144

rraditional company/business/enterprise see investor-owned

training see also education $20,55,57,81,106$

transfer rights

Tullis Russell

Tuominen, $\mathrm{P}$

types of co-operatives: housing

$19,20,21,66,90$

retail

credit unions

$15,36,66,67,71,90,155$

health

$20,21,163$

consumer $24,35,57,65,67,69,71,90,123,163$ worker

$18,20,21,31,35,38,39,40,57,66,68,69,72,73$, $79-94,102,104,113,124,127,128,129,138,139$, $142,143-6,155,162$

producer

hybrid

$57,66,67$

insurance

$65,66,69$

community

66

primary

20,66

secondary

18,66

18,66

UBH International

125

UK co-operative movement

153-5

UK Employee Ownership Index

126

ULGOR

89-90, 93, 94

Unicorn Grocery

40

unique selling point (USP)

23-4

United Airlines (UA)

140-1

United Nations (UN)

University of Wisconsin

Center for Cooperatives

60

UN Year of Co-operatives

44, 166

US Federation of Worker Cooperatives

20,96 
value-added 80

values 16

Venture Capitalist 115

Voestalpine AG 141

voluntary organisations

$10,17,72$

voting rights 33

Waitrose 108

Wales Co-operative Centre 160

Ward, S\&B 80

Welch, J 121

Wilkinson, $\mathrm{R}$ $126,157,158$

Worker Co-operative Code of Governance 84

worker takeover 139

working capital model 17,39 


\section{SCOTMID}

co-operative

The co-operative membership

\section{$\mathrm{E} \cdot \mathrm{S} \cdot \mathrm{R} \cdot \mathrm{C}$ ECONOMIC \\ \& SOCIA L \\ RESEARCH \\ C OUN C I L}

\section{Knowledge \\ Transfer \\ Partnerships}

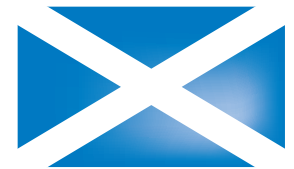

The Scottish

Government

Riaghaltas na h-Alba
The United Nations has declared 2012 to be the International Year of Co-operatives in recognition of the impact that co-operative enterprise has on more than three billion people across the globe. Co-operatives contribute to national and local economies in virtually every country by championing an ethical approach to business underpinned by internationally agreed values and principles. Yet despite the wide-ranging successes of cooperatives, in financial terms as well as in the development of sustainable communities, the study of these democratic forms of enterprise remains surprisingly absent from the curricula of most university business schools around the world.

Designed primarily for undergraduate students, Democratic Enterprise provides an introductorylevel analysis of democratic models of enterprise, namely cooperatives and employee-owned businesses. A supplement to any course that deals with these topics, it also stands alone as a template for academics who wish to incorporate material on democratic models of enterprise into courses relating to economics, business studies, sustainable development, enterprise, and organisational theory and behaviour. 